


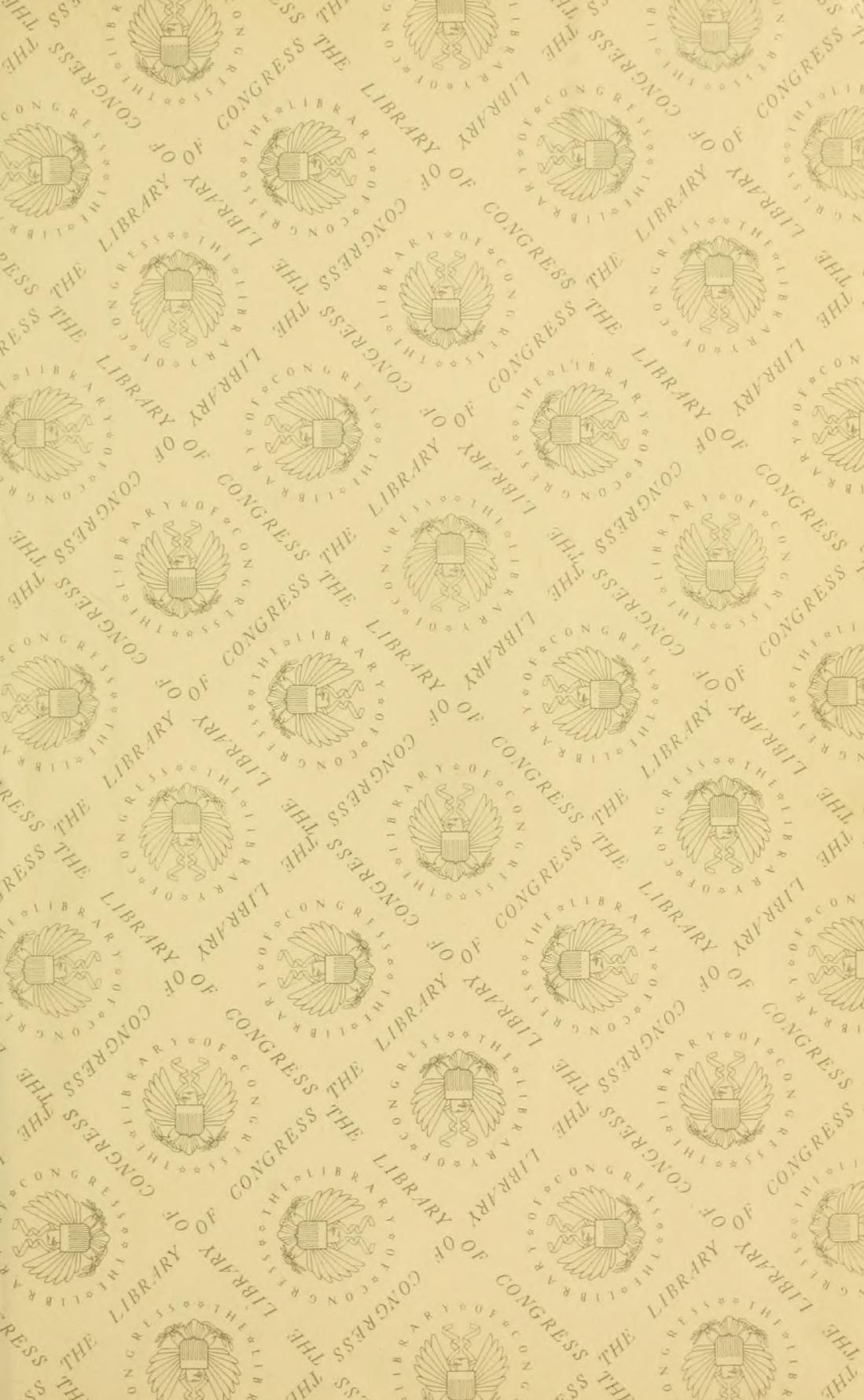









\section{BREEDING, TRAINING.}

\section{f}

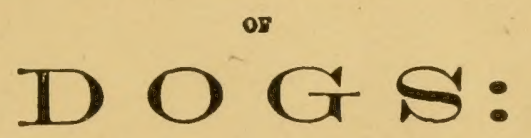

Together with an easy and agreeable Method of Instructing all Breeds of Dogs in a great variety of Amusing and Useful Performances.

ENOLUDING THIRTY-CNE ILLUSTRATIONS OF THE DIFFERENT BREEUS OF DOGS, POETIUALLY DESURIBED.

\section{By FRANCIS PUTLFR,}

AOTBOR OF THE "SPANISB TEACHER," "FRENCH SPEAKER," "DOGE POEHCALLY DESOKIBED AND ILLUSTRATED," ETO.

$$
-\longrightarrow
$$

FIFTH EDITION, REVISED AND ENLARGED, WITH AN APPENDIX.

Brooklyn, E. D.

PUBLISHED BY D. S. HOLMES,

89 Fodrth Street. 


\section{Entered, according to Act of Congress, in the year 1857 , B Y F A N I I B U T E R, nt the Clerk's Office, of the United States for the Southern District of New York.}

Copyright, 1877 , by D. S. Houxes. 


\section{INTRODUCTION.}

Bors a Poet, by instinct a Naturalist, and iy profession a P!hilosopher, I offer no apology in introducing to you a series of Canine poems, descriptive of the varied types of Dogdom; trosting that my delineations may prove both instructive and amusing to the reader, and profitable to the Author,

\section{ERANCIS BUTLER.}




\section{PUBLISHER'S NOTICE.}

The Publisher trusts, in giving to the pullic this fiftl edition of the work of Francis Butler, deceased, that the additions and embelishments which he has spared neither pains nor expense to procure, will gratify the admirers of the subjects illustrated. Of the late author of the work, it is useless to speak. He has been acknowledged, not only in this country, but in Europe, to be the best American authority on the subject he treats. Mr. Edward Jesse, Keeper of the Queens Park, London, in his "Anecilotes of Dogs," quotes from Mr. Butler's work as the best extant. 


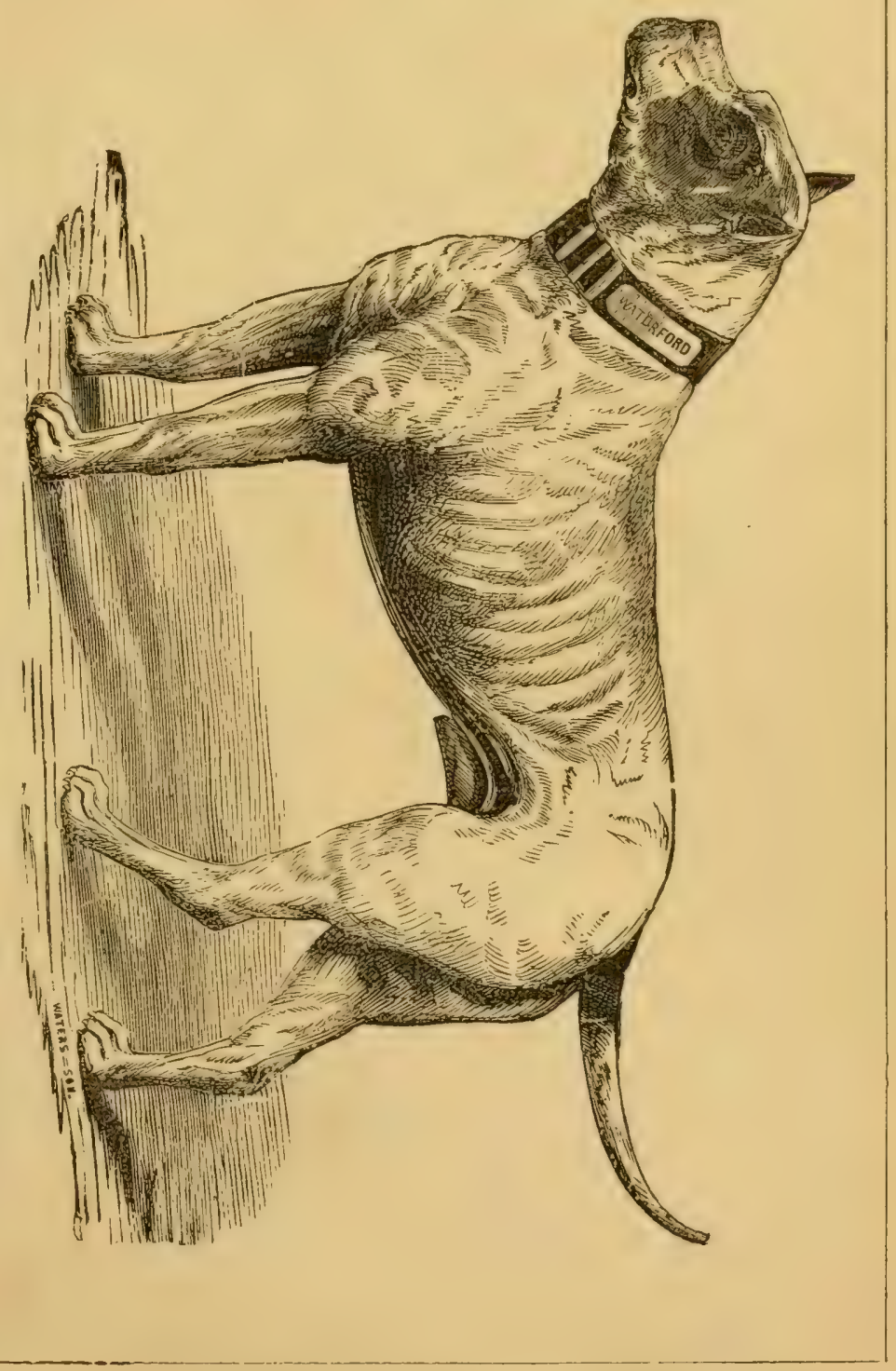





\section{CONTENTS.}

Introdaction................................. 12

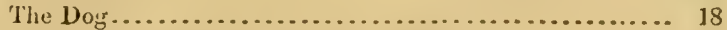

Origin of the different breeds of Dogs............... 30

Brecding of Dogs............................... 36

Sluts in heat. Pupping and Pups...................... 43

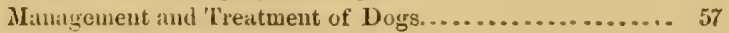

Teething, Teeth, \&c........................... 71

Crupping, 'Tailing, Dew-Claws..................... 78

Castration of Dogr. Spaying of Sluts................. 82

Introductory remarks on the Truining of Dogs............ 87

Down! Stop! Steady there........................... 96

Come in! líep in! Go on !.......................... 98

Shaking lomis; right hond; left houd; sitting up : standing

up; walking on the hind legs..................... 103

Fetching, Currying, Seeking, Finding............... 105

Going into and Fetching ont of the water............... 109

Going up stiul's, Going down stair's, Keeping ont of doore,

Staying in doors........................... 115

Jumping through a hoop, Over a stick, \&c. Down dead!

Stand fire

Steady! with meat on the Dog's nose. Meat in his mouth, not to be eaten.......................... 122

Fetching from the Store. Carrying to a given point....... 124

'Teach your doy to call you at it regular hour. ............ 129

To make trinsty watch dogs and good ratters............. 132

On the traiuin of fighting-dogs..................... 139

Comparative virtues of Pointer and Setter............ 145 
PAGE.

Training and Breaking Pointers and Setters............ 150

General remarks on diseases of dogs.................. 165

Diseases of Dogs, Fits.......................... 170

Distemper, Diarrhoea, Constipation, Stoppage.......... 177

Mange................................ 202

Rabies, Hydrophohia.......................... $\searrow_{0}$

Coughs, Colds, Asthmi, Inflammation of the Lnngs....... 223

Worms........................................ 298

Rheumatism, Palsy, Paralysis...................... 234

Diseases of the Eye.......................... 242

Diseases of the Ear........................... 249

Sprains, Dislocatrons, Fractures, Wuands, Swellings of the

Neck and Throat............................. 254

Sore Feet. ................................. 264

Illustrations described.......................... 267

Practical Ilints to owners. . . . . . . . . . . . . . . . . . . . . $\$ 86$

Engravings-Bruno........................ Frontispiece.

Prince, Siberian Bloodhound............. 10

St Bernird....................... ฉ

Newfomdland....................... $\cong 8$

Bloodhound........................ 31

Scotch Deerhound.................... 44

Foxhomd........................ 51

Harier............................ 64

Beagle..........................

English Greyhound...................... 84

Italian Greyhound. ................... 94

Pointer............................... 100

Setter................................. 110

Water Spaniel........................ 120

Cocker Spamsel.......................... 126

King Cbarles' Spaniel. .................. 136

Blenheim Spaniel. ..................... 146

Pointer........................... 155

Mastiff. . . . . . . . . . . . . . . . . . 158

Bull-Dog. ......................... 168

Bull terrier.......................... 1 78 


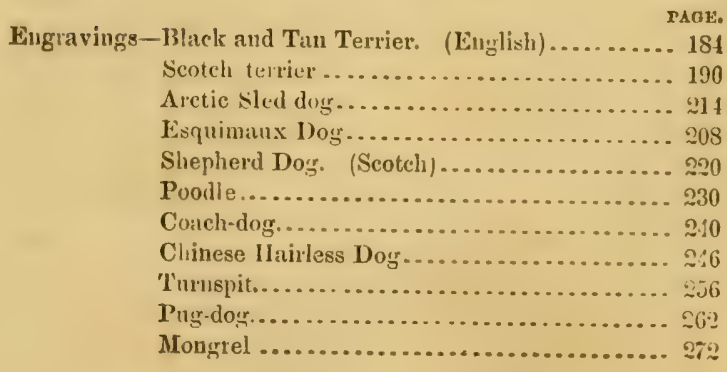

\section{CONTENTS OF APPENDIX.}

PAGE.

Allectotes of Dogr................................ 289

Camine Suicides................................... 3:3

Pride of the Border.............................. 394

Minos the learned dog.............................. 317

Begorrib........................................... 35

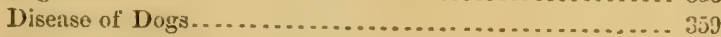

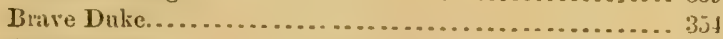

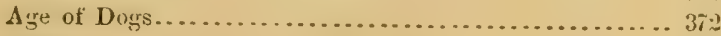

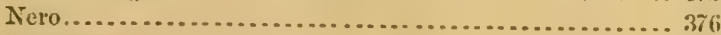

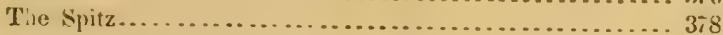

IIydophobia ................................... 379

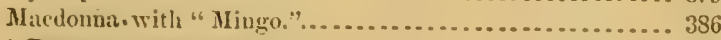

"Ditgmar" with "Oscitr."......................... 387

The Great liench Show......................... 3s8

liones of the Cimine Skeletun..................... 392

Glossary of Words............................ 396

Rules oi the Keunel Club........................ 400

R:its.................................... 107 


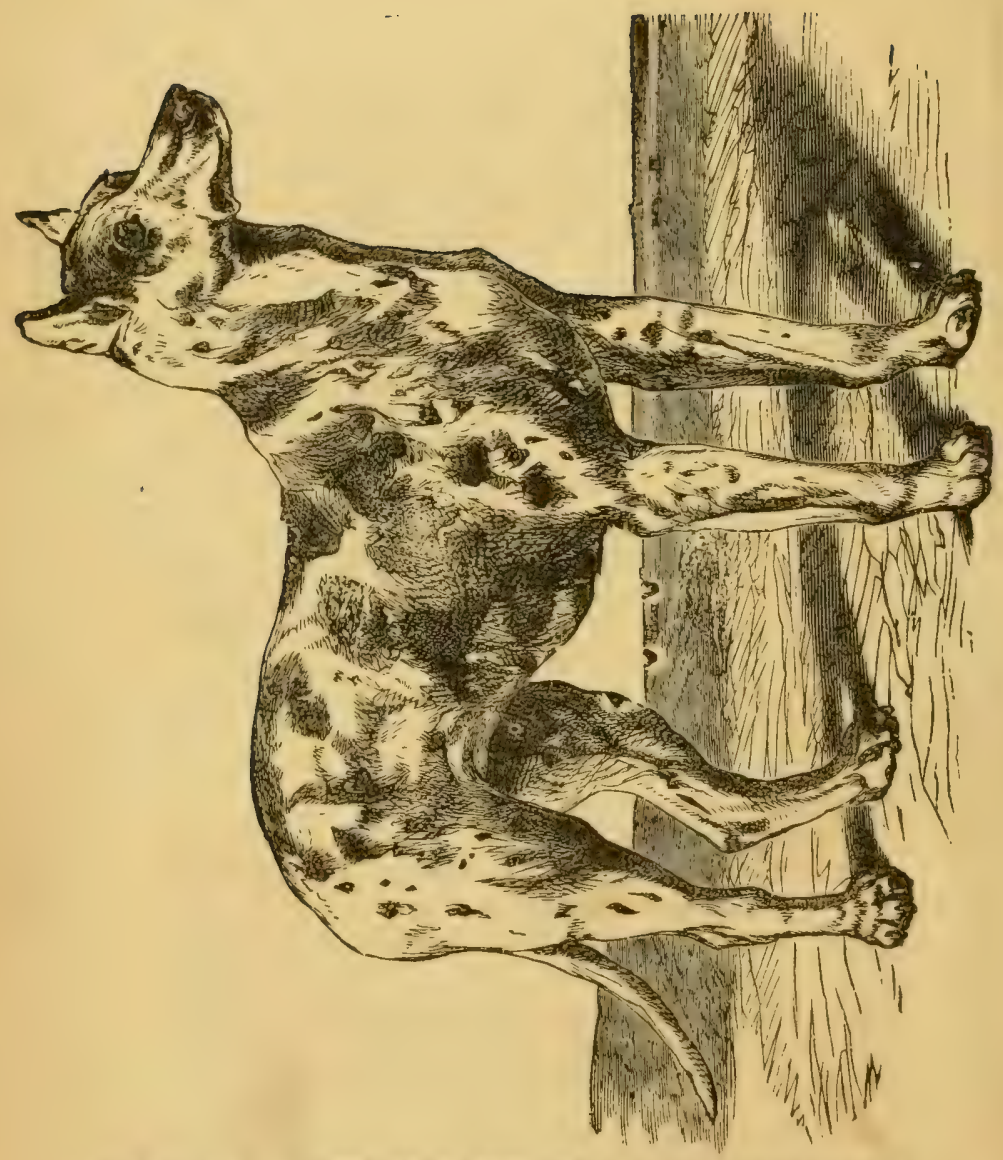

GREAT STBERIAN BIDODHOUND 


\section{GREAT SIBERIAN BLOODHOUND.}

Of ancient birth, in form majestic, tall, And rightitly styled by Buffon, king of all ;

Uis strength and prowess dare the wolf and bcar,

And fearless taunt the lion in his lair.

In lays of yore, in Rome he plared his part, An I furnished emblems for the sculptor's art; His daring feats the chisel!ed block portrays; llis fame survires, when crumbling stone decays.

When gladiators met in skill to vic,

His nolle form was seen expectant by ;

In cullecions power, the meaner beasts he scorne l;

Wi h aurious lare, the rampant tiger warned; Trained (1) the fizht an I cager tore the fray, Inameless. he rushes on lis quiv'rine prey, The palsiel riotin struer ales all in rain,

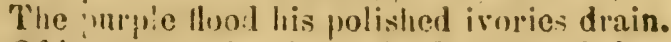
Of late a!ne, hat been the fact revealed, The: Ural moustains hat his l:ome concealed ; Fol travellers, of had fruitless songht to trace 'This noble scion, of the canine race.

Now brought to light, his beauteous form wo scan.

And wouder when and whence his name began ; While legend, statue, verse, his deeds recall, Our voices echo "Crown him king of all." 


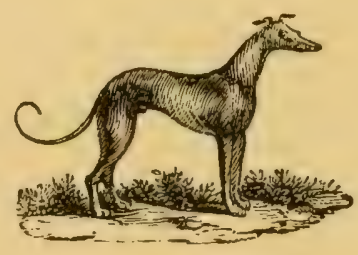

INTRODUCTION.

As Doctors seldom agree, and the wisegt Philosophers are occasionally deceived, it would indeed be somewhat surprising, should I, (a nonprofessional Dogmatist, possessing a rery imper. fect knowledge of anatomy and chemistry), at least draw some crooked inferences, both from standard facts and from the results of my own personal experience. We are all more or less liable to error; but whilst the false conclusions of Philosophers are handed down to us as incontrovertible truths, none daring to contradict, I humbly request my readers to credit nothing from my pen, that may be in anywise revolting to their renson and common sense. Great men can write what they please, and it were the height of presumption to doubt the soundness of their arguments, or question the correctuess of their conclusions.

Buffon, (the celebrated French Naturalist), 
readily accounts for the lack of hair on the 'Turkish dog, by presuming the stock to have lecome degenerated by Mange or some other cutaneous disease, thus bequeathing bare pelts and scabby hides to all their future generations. 'This same Baffon also states that the Shepherddog is the origin of the whole canine fraternity. Now I dare doubt the proof of either of these assertions : of the former, because, if a cutaneous disease were the cause of the absence of hair on the Turkish and other dogs. they would be the visible subjects of the contagion, whilst not only their hides, but their constitutions would be the sufferers; whereas, they are less subject to Mange than the heavier clad. In the second place, what ground can there be for supposing that the Bull-dog; Greyhound, \&c., are direct lineal descendant; of the Shepherd-dog, when there is as much difference even in the varied breeds of Shepherd-dogs, as between the Newfoundland and Pug! But these conclusions are considered as undeniable facts. Why? becauso the great Buffon says so.

Youatt, an esteemed author on canine pathology, remarks: "It is singular that the Grey. hound exhibits su little fower of scent; but 
this is simply because he has never been taught to use it, or has been eruelly corrected, when he has attempted to excreise it." If this be fair reasoning, it might also appear logical to infer, that the offspring of animals, who had been broken from eating meat, or barking at night, would naturally inherit the particular teachings of their forefathers. I am willing to admit that tolents to a certain extent may be hereditary, but the sudden annihilation of an instinct I cuuld never believe, before I had rais a litter or two of three-legged puppies, from a slut who had unfortunately lost a limb.

The same author also states that it is only in England that the Shepherd-dog injures and worries the sheep. I can account for this assertion in 110 other way, than by supposing that the writer of it had not yet crossed the Channel, or he might have returned with the impression that Paris Poodles all learn to dance. He also appears to take it for granted, that the relative weight of the brain is an unerring criterion of intellectual power; and to illustrate his theory, he adds, that the brain of a man is a thirtieth of his entire weight, that of the Newfomrland, a sixtieth; of the Poodle, a 
hundreth; and of the fernoious and stupid Bulldog, only a thres hundredth part of its entire weight. This may be true, but, as it does not tally with my experience on the subject of canine phrenology, I cannot corroborate such a conclusion: for instance, it would be difficult to prove to me, that the offspring of a cross between the Bull.dog and Newfoundland would only have half the sense of a Newfound land, pure, any more than I can believe that the Newfoundland has two-fifths more of intel. lect than the Poodle. Besides, I have made mauy researches among canine skulls, and am rather inclined to award the premiun of merit to quality than to quantity. Pliny, the great Historian. states that the King of Albania made Alexander a present of a Dog, to which the latter introduced wild Boars and Bears. Of these the Dog took no notice, upon which Alexander ordered him to be killed for his cowardice. When the King of Albania hears of this, he sends Alexander another Dog, telling him he should not make a trial with such insignificant animals, but rather with a Lion or an Elephant. Alexander being much surprised, (and well he might!) made immediatc prepara- 
tion fur a trial, and soon saw the lion prostrate, with his back broken. Then the lilephant was prodnced. 'The Dog maintained such an ingenious combat with the Elephant, that the latter ultimately came down with a crash, that male the carth tremble with the fall. In reference to this, Youatt says, that possibly the English Bull-dog is the same breed. Only imagine, gent'e reader, an English Bull-rlog lreaking a Lion's back, and overcoming an Elephant in single combat. Now the largest English Mastiffs have been loosened on the lion in successive pairs, a id were annihilated in a twinkling. Pliny's Dog then must indeed have been a Rouser! 'The effects of climate are now easily accounted for! What would Bufion's original Shepherd-dog have thought, had he witnessed the strength and prowess of his dauntless descendant?

I do not quote these remarkable sayings of wonderiul men, either as a critic or a fault finder, but to plead for mercy in advance in behalf of my unworthy self, should I, perchance, be accused of similar misupprehensions. I trust, however, that by carefully keeping within the linits of uny lange, and avoiding the 
untathemable depths of metaplyysical supposi. tions, I may somewhat elucidate and simplify the mystified art of Dog-management, presenting simple facts, free from incomprehensible technicalities, and in such a light, that thev may be understood. and freely digested by the non-profissiomal.

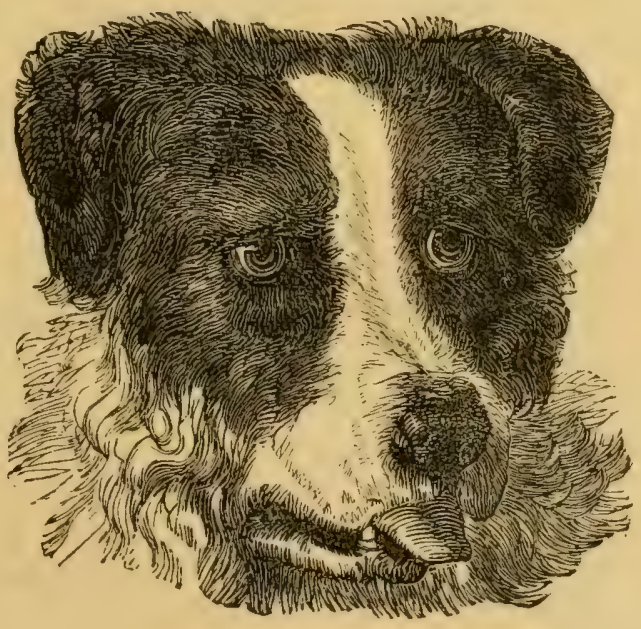




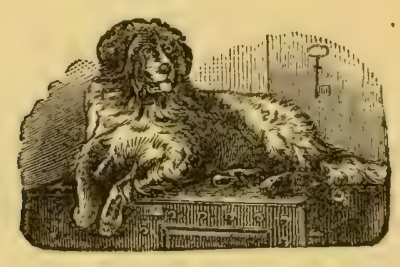

THE DOG.

The Dog appears to be a native of erery cli mate : in the frigid regions of the North, mider the burning sun of the Tropics, or in the more temperate climes, he is to be found the faithfinl associate, guardian and friend of man ; whilst, if we are to believe what everybody says, the most sagacious, knowing, tractable, learned and faithful, are common in every part of the habitabie glabe. From the mammoth St. Bernard, down to the darling, dear, tiny, little lap-dog, no matter what breed, what cross, what size, what color, or what his peculiar properties or propensities, the farorite is considered by his owner, as knowing far more than the majority of other breeds. The St. Bernard has rendered himself famous, by his charitable feats in re lieving snow-bound trarellers; the Newfound 
land by saving hmman beings from drowning : the Poodle by his aptness in acquiring a host of amusing tricks and antics; the sinoting Dog, by his serviees in the field, contributing both to the pleasure and profit of his master; the pet, (whatever may be his pedigree), for his almost incredible foresight, julgment, discre. tion, attention, cleanliness, \&c., in fine, to hear some people speak of their pets, one might be led to believe their dogs lenrued enough to instruct the whole family. I am only endeavoring to show by this, that the society of man, together with clucation and the foree of habit, produce about the same effects on one breed as on the other. I am often asked which kind is the most easy to teach, and I an certainly unable to give any satisfactory answer. Whilst almost every breed of dog has its peculiar character. istics, and is more apt at one branch of tuition than another, still, as a whole, I can scarcely admit that the honorable nember from Newfoundland, or the noble representative of st. Bernard, is more capable of instruction than the learned Poodle from Paris, or the thirsty Bloodhound of Cuba. By habits, education, good society and gool managenent, thej wil] 
all excel in their varied spheres, and will all be considered, (a: 110 doubt they are), the most wonderful animals in the world. A large hantsome dor, or an elezant pet, is generally observed to be the most tractable, and gentle. manly animal. He receives a lesson at every step, his master or mistress is proul of him, he accompanies them around the house, and ofttimes in their travels; he must be introlluced to a large circle of acquaintances, who are called on to witness his performances, and testify to his merit. The pretty, little dog, in the house knows the varied habits and inovements of the inmates, the hour to rise, and the hour of retirement; breakfast, dinner and tea are seasons with which he is perfectly familiar ; in fact, he appears to understand a hundred things he never was taught; whilst the poor beast of a watch-dog, at the end of his four foot chain, is justly accused of being one of the most untractable, illiterate brutes in creation. Society, habit and example are the sole causes of this difference. Had the pet been on the chain, and the forlorn watch-dog inside, the reverse would have been the case. 
Some date the origin of the Dog to the Wolf, but as there is a wide difference both in their physical construction and intellectual capabilities, there is no foundation for such an insupportable theory. No: a dog is a log, always has been, and ever will be. He differ's widely in many respects from any other quad. ruped, surpassing them all in sagacity, intellectuality and filelity. The elephant, the horse, the cow, the monkey, and others may portray erident symptoms of instinctire reasoning, but the dog will ahsorb more instruction in one short hour, than the whole phalanx could digest in a week. He will learn where no lesson is given, and from knowledge thus acquired, he is fully competent to act as the tutor of others. With his wonderlul performances, and disinterested fidelity, the whole world appear to be conver sant. A recapitulation of his varied foats would be a somewhat useless devotion of space, whilst to pass them over in utter silence, would be unjust in one, who is proud to acknowledge him his trustworthy friend. In various parts of the world, I have traced the peculiar characteristics of the canine race, and have found that they stand everywhere pre-eminent 


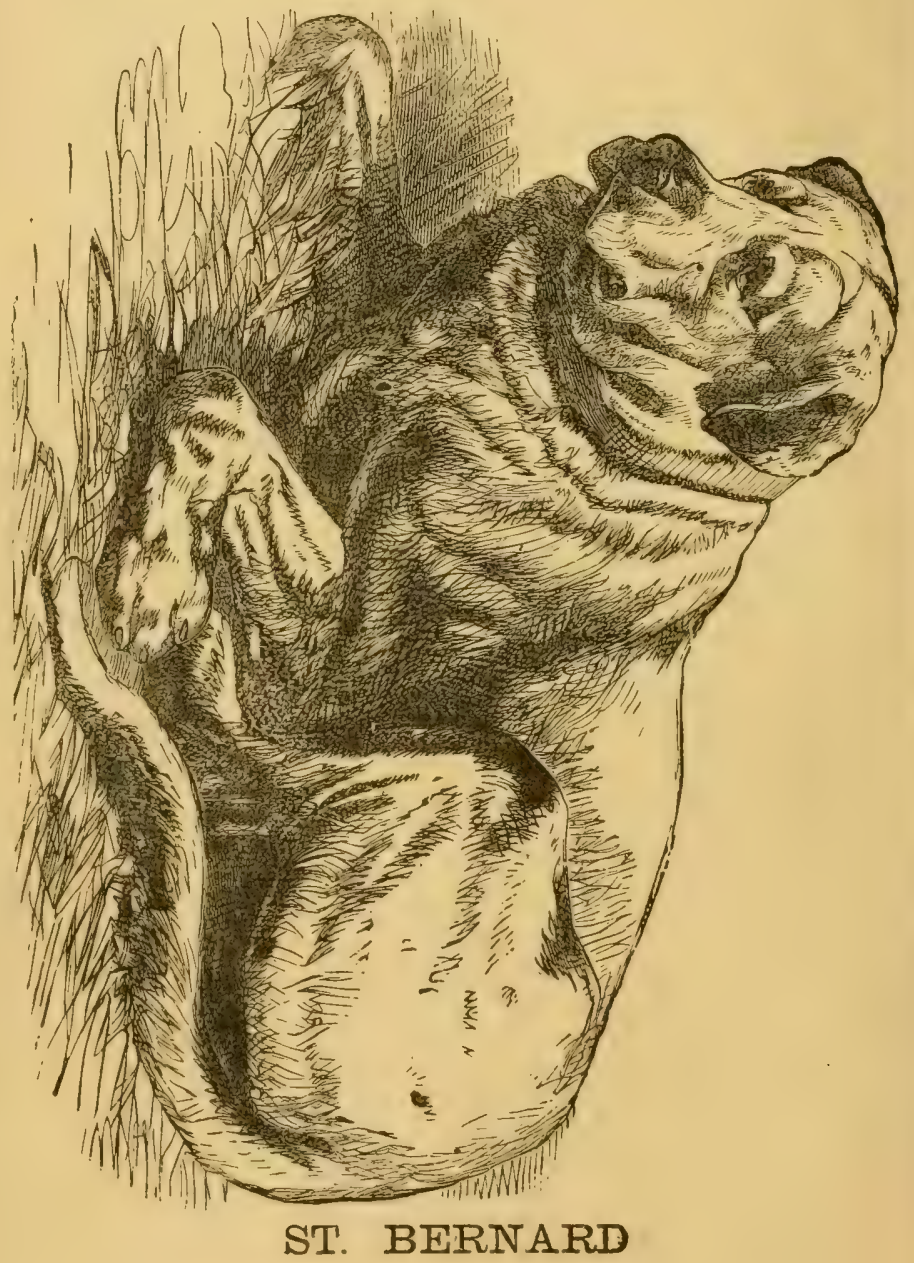




\section{SAINT BERNARD DOG.}

Of tawny color, and of lion size,

In muscle powerful, and by instinct wise,

On his bold front, there lurks no treach'rous grin,

Candor without, and honesty within;

'The trusty Guardian of the holy friar,

Sleepless, he dozes, by the convent fire ;

But roused to action, braves the frost and snow,

To greet a fi iend, or face a daring loe.

On barren peaks, abstemious monks grow fat,

Feasting on strangers' charity at that;

Without a friend, e'en to a saint 't were hard,

To brave the rigors of the bleak Bernard.

From this huge mount, tie Dog derives his name; Some doubt his pedigree, but none his fame:

For stranger's oft, when ice bedecks the ground, No friend to help in that drear region round; With hunger perishing, and limbs congealed, To the chill grasp of death prepare to yield: When lo! he comes! the gallant Bruno hies! With food and cordial, e'er the traveller dies. Some may exclaim, "Can there a man be found, Who'd dream of bartering such a priceless hound ?"

But then again, Lives there a monk so rash, , To lose a customer, who hands the cash ? 
above all other animals in their astonishing powers of mental development--their disinterested fidelity and attachment to man. Under chastisement, neglect and starvation, they are still devoted to their master's will, and ready to perish by his side, rather than forsake him; his companion by day, and his guard by night; the author of his sports. the sharer of his toils, and ever in waiting to obey his commands. With all these qualifications, it must not be forgotten, that great talen ts either uncultivated or misdirected, may be, and often are, turned to very bad account. For this simple reason, " $D o g$ " is a bye-word among all nations, because, travel where you may, thousands of these poor brutes are either left to the tender mercies of unrestricted loaferdom, (consequently they are accused of transgressing laws which they were nerer tanght to obey), or eren with respectable owners in the majority of cases, they get no kind of instruction whaterer; it being generally considered an all sufficient virtue, should they happily succeed in waking up the family, two or three times in the night. If a dog should, however. chance to break loose, kill a dozen chickens, four ducks and a sheep. steal 
half a leg of mutton, and worry the cat, tear up the flower-beds, or play havoc with the clothes-line, ten to one but the general opinior is, that he ought to be shot or got rid of im. mediately. Now I contend that he has done no more than might have been expected, eren from an uncivilized biped. It was nothing more than a perfectly natural impulse unrestrained. If we show a rat to a terrier, and he refuse to seize him, we set him down as a cowardly beast; but we can either urge him to kill him, or teach him to respect him. He may not require excitement, but at any rate, he may be easily restrained. 'The greatest rat killer I ever owned, or ever saw, was my Bull-terrier. dog Tiger, (whose Life and Adrentures, lately published, may be worth the perusal of all admirers of canine character). I could leave him in a room shut up with half a dozen rats, running around him, and had I told him not to touch them, they were perfectly safe in his keeping ; but at a word, and in a few seconds he would annilsilate thom ali. Were he erer so hungry, he would hold meat in his mouth, till I bid him swallow it; he would obcy a multitude of rommands, given in a whisper; yea, a variety 
of so called remarkable things could old Tiger do. Now, I am not aware that he was born with talents superior to his fellows, neither did he belong to a race the most renowned for their intellectuality, but he had his adrantages. $\mathrm{He}$ was seldom out of my sight or hearing, and his progress afforded us mutual pleasure and satisfaction. During the seventeen years of his life, I seldom had any occasion to correct him with stripes; he knew the expression of my countenance, and the sound of my voice too well to require it. So accustomed was I to the different intonations of his bark, that to me, it was nothing short of absolute speech. I repeat, I do not quote him as being naturally more gifted than his fellows, (although there is an equally marked lifference of capacity in dogs as well as in men), since I have had many who profited equally, according to their advantages. I merely introduce his respected memory, to prove to a demonstration that dogrs are really worthy of respectful consideration, and will amply repay any reasonable trouble that may be bestowed on them ; whilst on the other hand, he who would deny his guardian the 
privilege of a common school education, should be called to account for his short-sighted, and crucl neglect.

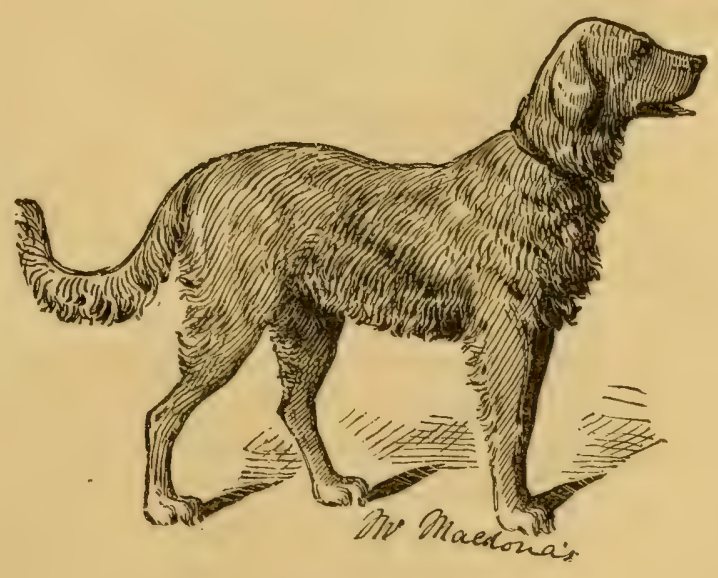




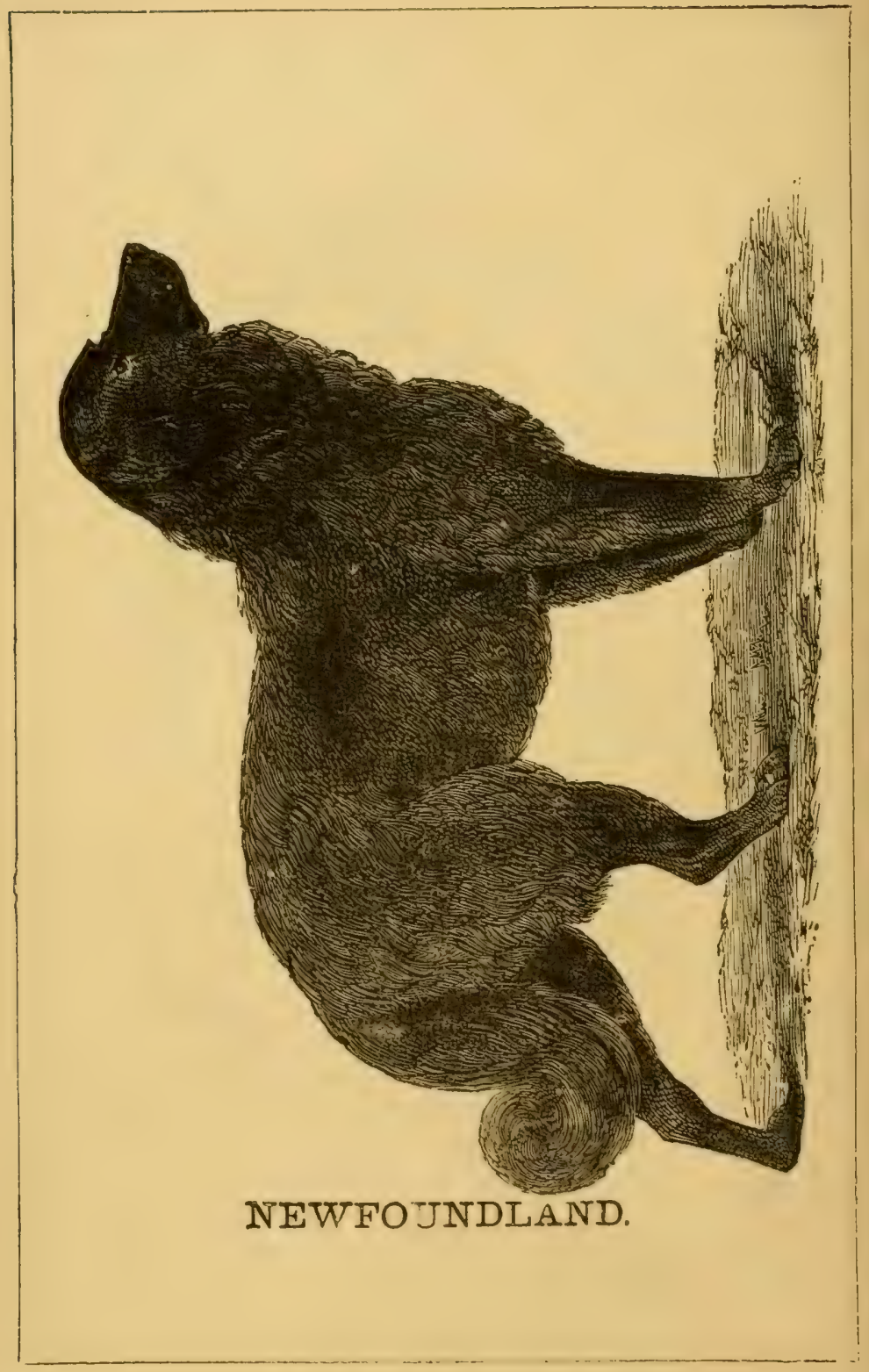




\section{NEWFOUNDLANI) DOG.}

Of glossy black, in form and bearing grand, The noted Fisher-dog of Newfoundland;

Water lis element, the sea his rest,

Of all anphibions, surely he's the best.

Massive in limb, his organs well defined, His shaggy coat defies the stormy wind;

With dauntless foot, he stems the ocean spray, Nor foaming surge can check his onward way. From North to South, a household word his name,

While East and West, re echn loud his fanso; His truthful looks wit' confidence inspire The cradled infant and the aged Sire.

"T were vain, in ver'se, his merits to relate;

A task, his virtues to exagrgerate;

Playmate by day, and sentinel by night, The parents' guardian, and the boys' delight. The tempest rages, and the sea grows wild, The mother screams, "Who'll save my drowning child ?"

The gallant Neptune dashes from the shore, And rescues him who sank to rise no more. The house in flanes, or burglars breaking through ;

Ho'll guard your purse, and rouse you quickly too ;

In joy and sorrow, he's your trusty friend, Honest and faithful, bribeless, to the end. 


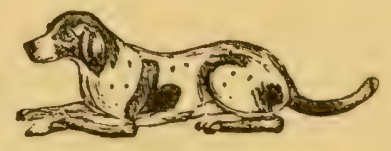

\section{ORIGIN OF TIIE DIFFERENT PRETES OF DOGS.}

'T'us is rather a hard subject for a liscourse; such is the diversity of opinion, in regard to the prime origin of the different shades of Dogdom. 'There being nothing more than an almost imaginary circumstantial train of doubtful eridence, to substantiate a rariety of suppositions, we are left somewhat in the dark as to the peculiar varieties of the parentstock. From a lengthened experience in obtaining crosses of different breeds, and from a thousaud instances I have witnessed of the raried products of untraceable mongrel stock; from the incredible changes which climate affects even on the same generation, I am inclined to believe that many breeds, now consilered as genuine, might be again reproduced from opposite races. I believe this, because I have often proved it 


\section{OHIGIN OF DIFFERENT BREEDS OF DOGS. 31}

There are, however, some races which bear more the impress of originality than others, both in their outward appearance, and in their instinctive propensities. The courage of the Bull-dog; the fleetness and sight of the Greyhound; the game hunting attitudes of the Pointer; the long curly ears of the Spaniel; the peculiar drooping ear's of the Hound. These and other examples of peculiarities of physical structure, and natire properties, lead us to infer an originality of caste. But from these few only, which I have mentioned, what an infinite variety may be propagated! The Ifound with a Spaniel, and the offspring crossed by a Pointer would certainly be running great risk of producing a Setter. The Setter thas formed, crossed by a Bull-dog, might turn out some tolerahle fair Terriers. Thus, by the blending of different stamps of animals, there is scarcely any limit to strange productions. Add to this, the effects of habit, diet and climate, and it is easily conceived how crery generation is introduced to a novel canine race, of which our ancestors had never dreamed. An animal not only changes his appearance to suit the climate he may be called on to inhabit, but 


\section{ORIGIN OF DIFFERENT BREEDS OF DOMS.}

moreover, his very instincts are forced into that particular channel, best adapted to the life he has to lead. Like man himself, he is in a great measure the creature of circumstances, and his peculiar attributes and acquirements are to a curtuin extont hereditary, as well as his snub nose, curly ears, or spindle shanks. The effects of climate on animals are really astonishing. Witness only the Merino sheep in Cuba; the Norman horse in London: com. pare the fur of the fox or rabbit in different latitudes, and you will be convinced what a variety of changes may be thus produced on the animal system. 'This, together with the constant introduction of new stock into almost every country, will account in a great measure for the numerous varieties and sub-varieties of the canine speeies. The breeds best known and most in use in this country, are the Pointer, Setter, Spaniel, Fox-hound, Beagle, Greyhound, Bull-dog, Bull-terrier, Scotch and English Terrier, Newfoundland, St. Bernard, Scotch and English Shepherd-dog, Poodle, \&c. From these alone, only imagine what an eadless transmogrification might be effected! Some of these make good cross breeds, particularly the 
St. Bernard and Newfoundland. This amalgamation adds to the beanty of the St. Bernard, and to the size of the Newfoundland; and, I think is the happiest mixture for an imposing and trustworthy family watch dog. Nevertheless, as this is the only cross I care about, I shall not enlarge on the subject; in other cases I prefer the pure stock, as far as it can be depended on, unless a cross be persisted in, until it turns out to suit one's purpose. Nevertheless, a little Hound in the Pointer, a little Spaniel in the Setter, \&c., if judgmatically infused, may serve to arouse the dormant energies of an out-bred stock, and impart new vigor to a novel procreation. In fact, no breed can be sustained, without an occasional sprinkle of foreign blood, except, at the risk of sacrificing health and strength, and of eventually dwindling our chosen ones to perfect nonentities-weak, puny, lifeless, worthless.

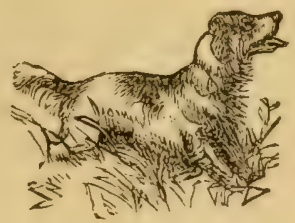




\section{THE BLOODHOUND.}

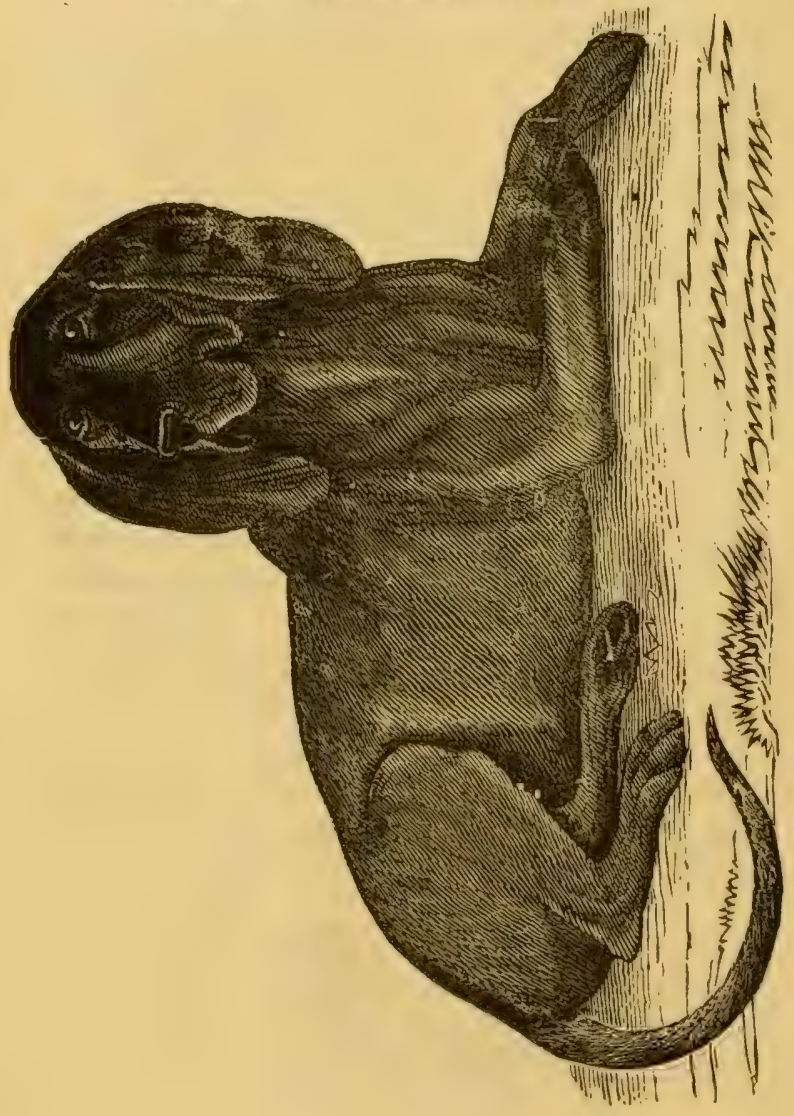




\section{THE BLOODHOUND.}

Dreaded his name, for bloody deeds renowned, Once in old England, now in Cuba founu. Ears broad and pendant, heavy drooping jowi; Fearful his bark, and ominous his howl. Of color tawny, or of reddish tan, Sometimes the friend, yet of ' a foe to man ; of nerrous limb, with teeth deep set and long, Disputes the mastery of the canine throng. 'The thief's antipathy, the murderer's dread, He tracks their patis way, no tes their every tread; On tireless foot and panting for the fight, Trails the doomed fugitive, by dity and night. And men there arc, who hire him by the day, 'To hunt the trembling Negro-runaway ; [flood, Nor wood. nor swamp, nor brake, nor bursting Can daunt his ardent rage, for human blnod; Onward he speeds, low scenting on the ground, With deep and sonorens yell at overy bound; The rate is o'er, the Bloodhound wins the day, His wreaking jaws in triumph seize the prey. His name a bye-word "A ferocious brute." His vice constrained, inhuman brutes to suit. For thirsty blood ıounds, if but rightly mann'd, Are kind and docile as the Newfoundland.

To prove my doctrme, I would here sssert,

'That virtue's often vice if kept inert,

That vice is virtue, when in dnty fouxh

For who would prize a disobedieut housil! 


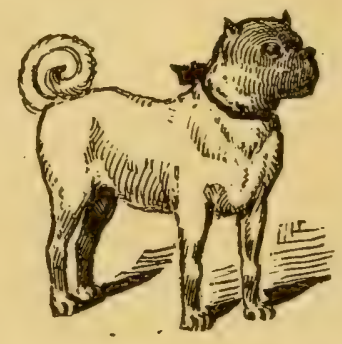

\section{BREEDING OF DOGS.}

Tr is an old saying, and a true one: "Nothing like a good beginning." This proverb stands particularly staunch with regard to dogs. Without a sound start, we shall be often subject to sore disappointments. When we consider the unsuitable amalgamations; the interminable, and almost incomprehensible transmogrifications; the oft trebly compounded admixtures, to which the canine race is continually exposed, it should inspire us with somerwat of diflidence, in attempting to define the originality of stock, or in deciding on the purity of blood, simply from outward appearances. Breeds of dogs are continually undergoing the raried changes of the kaleidoscope. When there may chance to be nine shades on the one side, and perhaps, thirteen on the other, it would be preposterous to inquire under what 
head to class the progeny. Certainly, they would be commonly termed mongrels; but not more than three breeds at most, could be de. tected in their appearance; whilst their peculiar characteristics could be named only after trial. It often happens, however, even from such an inscrutable compound as that above mentioned, that a dog of apparently pure stock may present himself. Hence we are often deceived. We get Pointers, that won't hunt; Water Spaniels, that won't face the water ; Newfoundlands intractable and sarage ; Bull-dogs that won't figlit; Charley Spaniels with long noses; 'Terriers with round heads; in fine, a multitude of animals with irresponsible hypocritical countenances, well calculated to subvert the judgment of a Buffon, a Cuvier, or of Butler himself.

I merely cite these examples, to show how careful we ought to be in the selection of Breeding-Stock. I have scen splendid Scotch Terriers from a Poodle; magnificent Newfoundlands from a Foxhound; beautiful Black and Tan Terriers from a Cocker Spanicl; also three apparently distinct breeds in the same litter; and a host of almost incredible productions, 
too numerous to put in print. A peculiar breed will often leak ont, from generations back, thus giving rise to the popular, yet mistaken notion, of a slut enclosing in lier womb the offspring of various sires. This idea is not only against the laws of nature, but contrary to common sense and experience. One plain fact, (it appears to me), is sufficient to decide the question. A slut will be in full heat during 10 or 20 days. Let us suppose then, that during that period, she has had intercourse with one or more males every day; if her whelps were fathered liy a variety of dogs, it is reasonable to suppose, (presuming them to arrive at the regular stage of cmbryo-perfection), that they would enter the world at periods, corresponding to the various times, when they were begotten; therefore a slut, (one of the random kind), would be from 10 to 20 days in bringing forth her young, which I have hitherto not found to be the case. I have a record of some fire or six hundred breeding sluts; sixty hours has been the greatest variation of time. between copulation and parturition. Some, I have put to the same dog every day, from the first up to the twentieth day. Now, wliy did'nt they pups 
at various periods? They were as likely to do it from one dog, as from a hundred; but they have not averaged between the first born pupps and the last, perhaps over twelve hours. 'Then again, those who have for sereral consecutive days been subjected to the embraces of Pointer, Poodle and Pug, are just as regular in bring. ing forth, as others who have been allowed one male alone. The difference often discernable in the same family of pure breeds, arises from some former and perliaps distant ama'gamation of another race. In breeding then, I repeat, be rery cantious in the selection of your stock. Trace their pedigrec, (if you can), their qualities and their characteristics; ayc, their manners and education; their constitutions, pluek, endurance, \&c. I cannot rid myself of the idea that eren talents and acquirements ate somewhat hereditary. The quail trembles at the tread of man, and with the very shell on his back, hurries off affrighted at the sound of lis footstep; whilst the young turkey, or chicken, (once wild as the quail), will become friendly in a few minutes: and in a few hours will follow a person about as his adopted parent. The steady habits of the parent stock hare 
thoroughly transformed their instinctive en. downents, and suited them to civilized life. Look at the tame rablit, (a more apt illustra. tion), the young ones are comparatively tame, when they first run about; whilst those of the same stamp, if born in the woods, at the least sound, would bolt off like a shot, from under the very mother that bore them. Do not suppose, however, that you can get a learned puppy ; neither can absolute confidence be placed in hereditary endowments. I quote these examples mercly to endeavor to substantiate my impressions in regard to the superiority of educated stock.

The next point to be considered is, the absolute Breeding. Authors are continually at variance as to the most appropriate ages for propagation. My own personal experience has not led me to fix on any definite period of canine development, as more particularly suitable for procreation, except in as far as health nd vigor are concerned. If the dog and slut be perfectly healthy, and fully developed; if they have lost none of their vigor ; if they be free from all taint of hereditary dicease, stock inay be safely relied on, from animals rarying 
in age from eighteen months, to eiglit ycars; and occasionally older. It is commonly supposed that the first litter is not good for much. I admit, there are cases, when the slut is in licat, before completing her growth, the pups would not, perhaps, be as fine; but as a general rule, Nature is the best indicator of procreative fitness. This, I really do believe, that dogs bred from very young, uneducated stock, are much wilder and more difficult to control, than the offspring of riper years. See that your brecders are symmetrically built; strong in the loins, good teeth, good coat, and well developed limbs. Reject contracted chests, narrow loins, decayed teeth, stinking breath, \&c. Do not breed in, any more than can be aroided; it tells unhappy tales, and if persisted in, to any extent, deteriorates the constitution, weakens the intellectual powers, and gradually extinguishes every spark of healthful vigor. If you are particular about breeding from the same stock, that dog should be chosen who is living at the greatest distance from his mate. This will make an astonishing difference, as climate, diet, habits and treatment contribute greatly towards a physical change. Wituess 
the same breed of dog, horse, cow, sheep, \&c., under different suns. If these causes work such a marked change, the principle inust be carried out in inè same ratio, in localities less distant. and climates less varring.

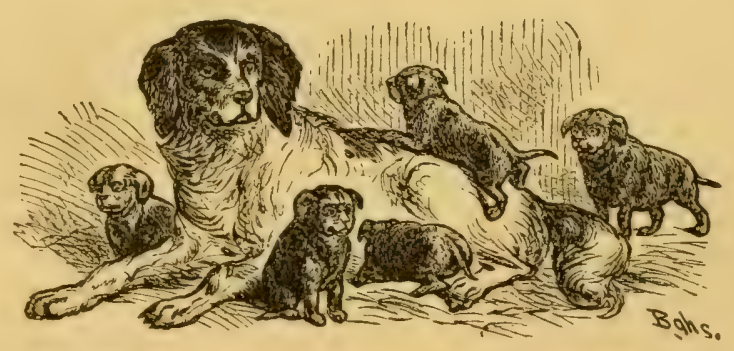

MB. JOHN E. T. GRAINGER'S SETTER "NELLY" AND BER PUPS, VALUED AT $\$ 5.000$. 


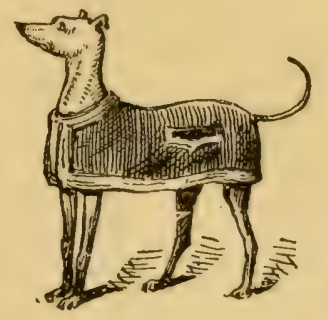

\section{SLUTS IN HEAT. PUPPING AND PUPS.}

ONE of the most important things in Brecding is, the absolute certainty that the female has not been tainted by forbidden suitors. Great caution is necessary during the copulative period, as both male and female are equally desirous of satisfying their lust at whatever risk. The slut then should be kept where no dog, (except the chosen one), can possibly have access. Of this, the owner himself should be absolutely certain, as hirclings are often ignorant and generally carcless aloout the necessary precautions. The general idea is that the heated period is of nine days duration; but this is by no means certain, as it differs widely in different subjects, varying from three sometimes to twenty days; perhaps the average may be nine or ten days. The female gencrally indicates its approach by a gradual expansion 


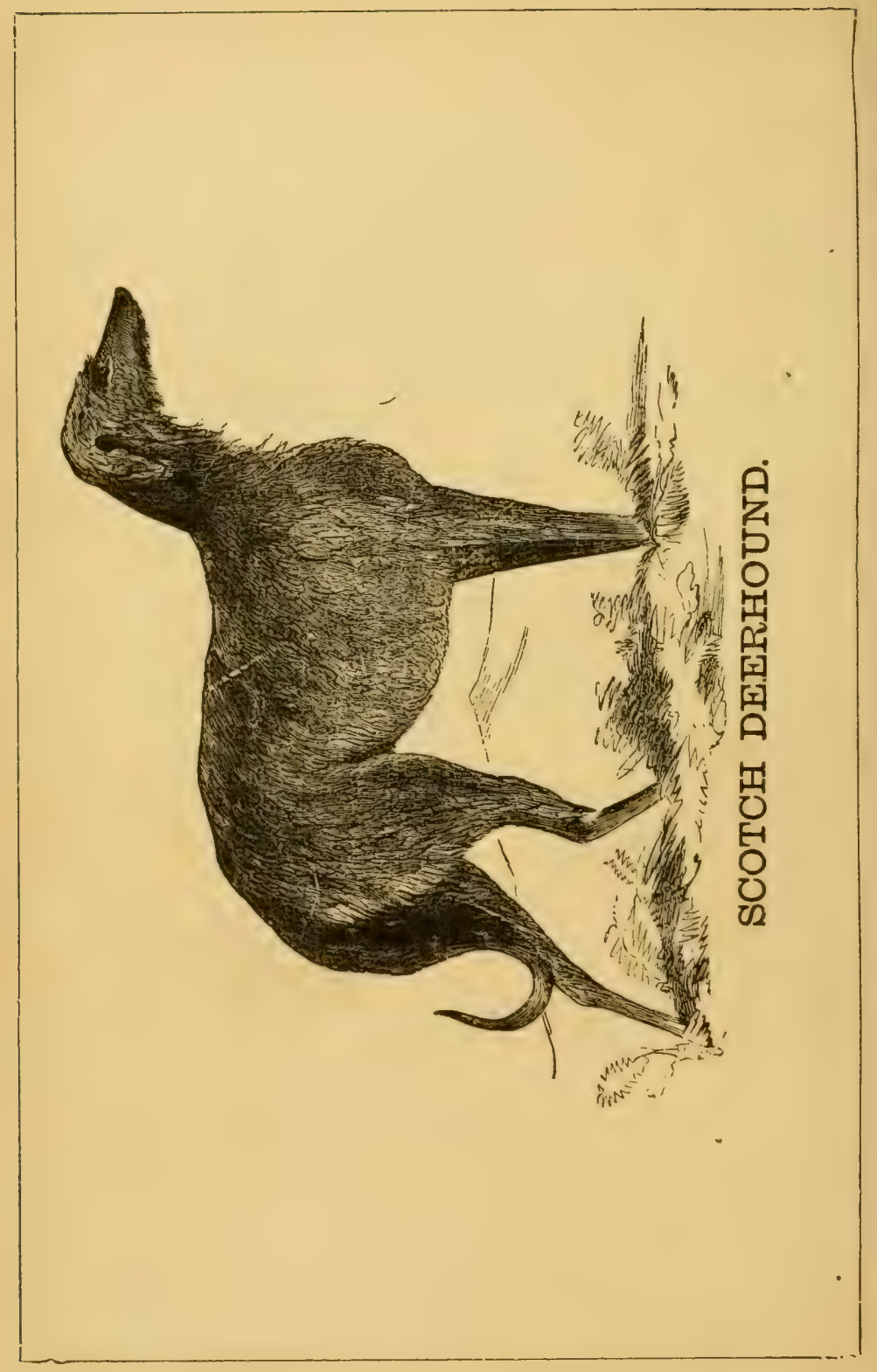




\section{SCOTCH DEERHOUNI.}

Full many a bard, his glorious feats has sung ; Full many a hall, his echoed praises rung;

Where trophied antlers o'er the feast preside, Bold Oscar couching by famed Iulfra's side.

Most noble hound! of Scotia's lairds the boast ? And highly prized on Albion's sportive coast! His brawny limb and wiry coat outvie 'The classic greyhound and the roughy Skye. In stature tall, imposing gait and mien, Near festive boards of Royalty is seen; Bright piercing ken and scrutinizing eye, Cool, dauntless courage, that none dare defy : His eagle glance, the distant game reviews, With lightuing speed, the bounding stag pur. sues ;

With bursting ardor, void of every fear, Impetuous rushes on the fated deer.

O'er rock and chasm, he darts, the claring hound, Nor onght arrests his bold and reckless hound; With fatal grasp, retains the destined prey, 'I'ho' mortal wounds his prowess ol't' repay. Mark well his joy, as home the prize they bea-, His martial step, his proud victorious air ; B! speaking gesture, glories in his name, find eyes exultingly the lifeless game. 
of the gencrative organs, from which, (previous to here heing prepared for the male) is observed to issue a boody lluid, more particularly visible ather her haring lain still for a time. These preparatory symptoms are of more or less duration, in diflerent suljects. I have koown them to eontinue a month previous to a prerlect derelopment, and eren then all communication with the male refused. Very rarely will the slut submit to the dogr. till this has passed off; indecel it is not fit she should, as the organs are not yet thoremohly conditioned for eopulation, and a favorable result cammot he anticipated. The female should, more properly, be put to the male three or tiur days alter she hasceased to hlecel, as, at the ontset, the womb is apt either to reject. or is muprepared to eherish the seed ; ponsepuenty arly amalgamations often prove fruitless. Should she continue in heat, for several days, alter having taken the male, it will bs advisable to hare the operation renewed. as the protracted expansive longing of the parts is apt to allow the eracuation of the semen. 'The female may be impregrnated the first, secomd or third time. Se. it is inipossihle (betore pupping) to say which. It is also, im- 
possible to know, for an ahsolute fact, (but experience has caused me to believe from incon. trovertible circumstantial evidence), that what has been done, may be undone. For instance, should you put your slut to a $\log _{g}$, who is considered an excellent stock-(retter), aud she should happen four or five days after to come in contact with another male, it will very often happen that the sccond is the father of the anticipated family. 'This of course, is proved by the day of the pupping. For this reason, I am not an adrocate of of t-repeated iloses; for, granting that it can be undone, it may be undone without being replaced. Once may be equal to a dozen times, provided both be in a prepared and healthy state. I generally arlvise twice, missing two days between the operations; especially, when we are not satisfied as to the time the female has been in full heat. Whilst I do not depend on it too errly, I often fuar lest it may be too late. It is not well to shut up the animals together, when it can he otherwise effected; the male is apt to wear himsclf out uselessly, which diminishes, rather than adds to the prospect of an increase. In case of necessity, when there is a difference in height of the 
two animals, a square board of sufficient size, may be used with two holes cut in it, to admit the legs of the slut (should she be the tallest ;) or for her to stand on, should she be the lowest. It may be raised to any height by placiug some. thing for the edges to bear on. Sluts intended for breeding should not bo kept too fat, neither when bearing; in the first place, they are very apt to miss; and in the second, to experience great difficulty and danger in brirging forth. Dogs too fat are also very indifferent and uncertain stock-getters. During pregnancy, grossness and excess of food should be particularly guirded against : especially with the more delicate breeds; at the same time the animal should by no means be keutiow. Food that is too strong for puppics is (in delicate constitutions), too strong for jearing-sluts. 'The mother is apt to get too fit and humory; consequently, the brood is with difficulty brought into the world, and the life of both mother and offering is jeopardised; secondly, the pups are often born full of eruptions, and more sulject to disease. House-pets, when in this state, should not be allowed to go up and down stairs; especially after the sixth week 
Numbers of litters are in this way weakened or destroyel, and numerous mothers sacrificed. It appears to me, to be an unnatural canine morement, this ascending and descending of steps, and I imagine, (with sluts in whelp), it strains the sustaining ligament, through which the nourishment passes to the embryos; this proving decidedly injurious both to mother and offspring. Regular exereise should alwars be attended to, and need not be serionsly diminish. ed on account of pregnancy. Sporting dogs, however, should not be hunted much when far advanced, as they are subject to sudden jerks, which might prove injurious. A snug, comfortable place should be selected, an! a warm bed should be prepared for the slut, to deposit her pups. She should be accustomed to it, for ser. eral days previous to her delivery. This generally has the effect of confining her labors to one spot; otherwise she is apt, in her pains, to drop them about at random, thus unnecessarily perilling their lives. Should she absolutely appear determined on the selection of another spot, it is better to humor her, and there make her as comfortable as possibie. A peeping, meddling curiosity at the time of nup. 
ping should not be allowed : she is generally far better alone, since inquisitiveness will sometimes cause the animal to injure or even destroy her young, in endeavoring to conceal them. Should she howerer show symptoms of lengthenod labor, small ilowes of castor oil may be administered every half hour, until an operation or a delivery be secured. Should a surgical operation appear to be necessary, you had better run the risk of doing nothing, than to meddle with what you do not understand. In such a case, apply to any, who may have had some experience, to help you out of the predicament. Mary things have been recommended, to facilitate labor, but not being satisfied of their safety and efficacy, I shall not introduce them here. I have never lost a sin. gle slut in labor yet, and have used no other means and pieca!tions than those here mentioned; I am therefore satisfied with my own treatment. The object of this work is not to repeat what others say, but to state what (I believe) I know myself. 'That thousands will differ from me, as I take the liberty ol doing from them, I have not the least shadow of a doubt, still I remain convinced that a bushol 
of exparience is worth a whole chaldron es hearsay.

Soon after puppingr, warm drinks are both soothing and beneficial, such as warm milk, broth or gruel or any light, warm cmollient, the patient may relish. But, it is not necessary to enferce it, or to disturb the family to insist on it; a little may be presented in a tea cup; if she partake of it, more may be griven. The pups should be as little handled as possible ; it distresses them to bear on their bowels, and the constant habit of handling them should be aroided, more particularly in delicate brecrls. If the slut should have an abundant supply of milk, the pups will not want feeding, before they are five weeks old; in fact, they are better without it. Should the mother be a poor milker, they may be helped along by warm milk and water, (half and half) light broths and such like, which they may be taught to lap as early as the third week, or they may be raised from a bottle, in the same way as a child, even from their birth. The main difficulty in raising them by hand, is in keeping them perfectly dry, warm and clean. With all possible attention, inere is nothing like a mothcr's care; never. 
theless, they generally get along rery well, by your :trictly attending to the albore. Keeping many with the mother too long, retards rather than promotes their growth, as they do not feet as freely, while depending on the mother; at the same time, perhaps, she may not be able to supply half their demands. One pup left with the slut generally out-thrives the rest, upon the principle that what will starve a family will fatten one. He will also, be generally more forward in his anties, from having been under his mother's undivided attention. 'I'he mother's snapping and pinching her pups is no proof of her wishing to get rid of them altorether. She will invariably allow them to suck, when she has any amount of milk for them, but as they would drag her to death, if they had their own way, she is compelled to repulse them in her own rlefense, and make them wait her own time. After the fourth week or sometimes earlier, it is crucl to force the slut to remain the whole time with them, as they are a source of constant annoyance to her. When this is the case, it is better to kecp her from them, except at noon-time and during the night. [ considerthe most eritical period for pups, to be 
between the age of two and four months. Bad food, lack of a comfortable bed, damp feet or too much exposure, at this tender age are apt to bring on Disiemper, Inflammation of the lungs or bowels, often terminating in hasty consumption. Nevertheless, a delicate bred pup should not be brought up too tenderly; the object should be carcfully to harden the consti. tution by degrees, according to the best judginent of the owner.

Suitable food, air, and excrcise are as essential to the health of the dog as to that of his master. This being attended to, he will seldom require either pill, powder or draft.

The best food for puppies is a well boiled mixture of meat and meal. Viz: Sheep's heads boiled to a rag, the bones all carefully remored, and the meat chopped fine and replaced in the boiler, then add about the same bulk of Indian meal; boil them well together about ten minutes, stirring all the time. Turn it out and you have a fine pudding to be fed at discretion. A little salt should always be added when boiling. The proportion of meal may be a little increa:erl, when the meat is more nutrisive. Aroid Pork and all salted meats, and 


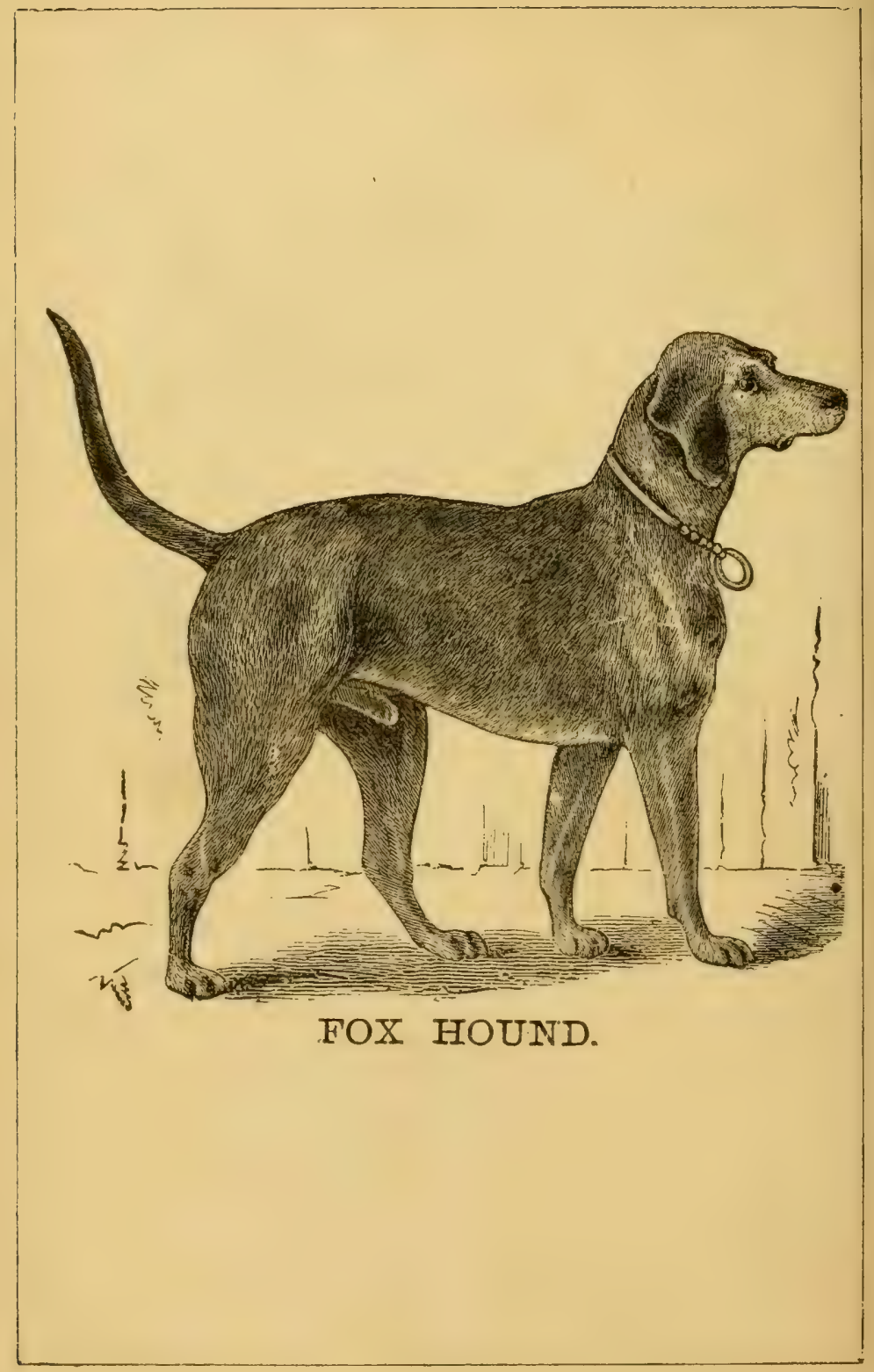




\section{HOX HOTIND.}

The prince of hunters. daghing. bold and free, The master hound, of sportive pedigreo. A bout the size of Pointer. more or less, 'Tho' stouter built and differing some in dress; Less fine in coat, in limb more stublorn grown, A Pointer's tail a Foxhound would disown. IIis graceful ear and eye of daring mood, Distinctive preface to unsullied blond.

'To English Staghound near akin may he, Yet lighter made, a flecter hound thin he ; Seldom or ever of one color bred, Black and tan ; red,white; black, white and red. 'The glories of hunting ye ne'er would deny, Did ye once sce a pack of such dog's in full cry ; Mark Jollyboy, Chanticlecr leading the chase; See Barmaid and Faraway quicken their pace; Note Dewdrop and Forrester hard on the track; With ohl Ringwood, heading the rest of the pack.

IIark! hark to their voices, so mellow and clear, As the brish of poor Renard, they carcerly near; On, on dash the huntsmen in scarlet and white, With their high mettled steeds, in ecstatic delight;

Hear! hear the glad cchos, that merrily fall O'er the soul-stirring feast, at the banoucting 로l. 
don't let the juppies wet themselves or lie in a damp or dirty bed. Look at them often and see that they are kept free from fleas, lice, dan. drufl, \&ec.

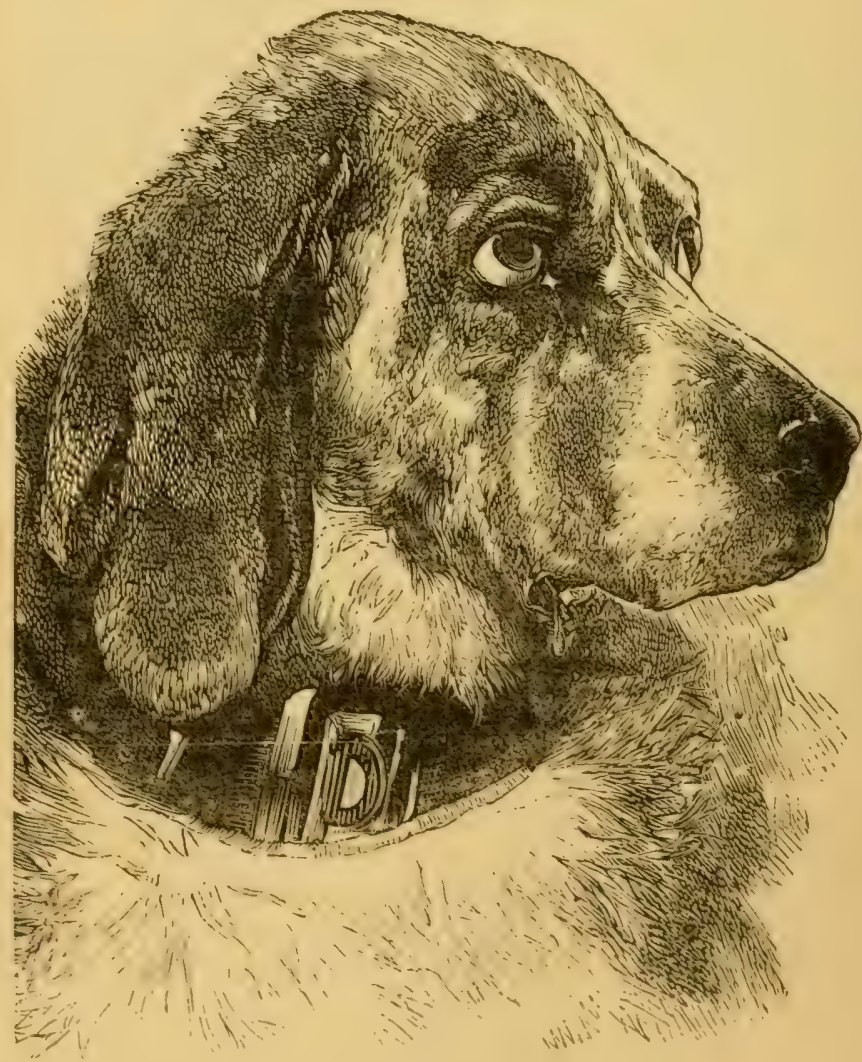




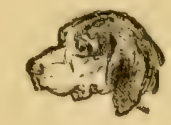

\section{MANAGEMEN' ANI) TREATMENT OF J) OGS.}

IT is more important to understand the management of a dog, than to be possessed of a thousand nominal remedies for the cure of his various ailments; inasmuch as the Antidote is at all times preferable to the Cure.

I shall first throw out a few hints on the guardianslip of pets. Whilst many are sacrificed, for lack of necessary attendance, there are thons:nds, who perish prematurely from orer doses of kindness. Delicate breeds of Dogs certainly require great care and attention in rearing, but overstrained tenderness is often more dangerous than culpable newlect. The dear little creature, that is allowed to lay un. der the store, that is stuffed with delicacies two or three times a day, that is never allowed to brea the the fresh air, except under a cloudless 
sky, is more subject to colds, fits, rheumatism, sore eyes and cars, worms, de., than the wortl. less mongrel, who was raised on the stret, nerlected and despised. The former are affected by every change of the atmosphere, and subjected to a variety of diseases, unknown to him, who has been hardened from his birth. I ask you then, neither to stuff nor starve ; neither to chill nor burn. A house pet should always have a sleeping-place allotted to him, warm and comfortable, not near the fire, nor in the damp. Anything round is hetter for an animal to lay in; such as a tastefully ornamented cheese-box, or anything of a similar shape. In cold weather, it should not be larger than to contain him comfortably. It is better for the following reasons : he may keep himseli perfect. ly warm, and his bed may be made exactly to fit him; it also takes up less available space than any other shane. He shonld nerer he fed to the full, neither cxeited to eat, when he appears disinclined. Lack of apjetite, so com mon to pampered farorites, is generally the result of an over loaded stomach and disordered digestion. This is easily cured by medicine, but more safuly and simply without it. Fast 
him for twcuty-four hours; after which, keep him on hall his ordinary allowance: if it agree with him, and he keep in fair condition, contime the regimen. Nursing in the lap is injurions; not in itself, but the animal is thereby sulyected to constant chills, in emerging from a snoozy warmth to a cold carpet or chilly bed. A dog accustomed to the lap is always shirering after it. and renders him:clf quite troublesome by his imprortmate alderes. A molerate share of mursing is well enough, but should be indulged in only as an occasional treat. Great care should he taken in the washing of delicate dogi. When this operation is performed, they should be rubled perfectly dry ; alter which they should be covered, and remain so, till the shivering hats completely subirled. The water should be only blood-warm; it is far better than hot, and not so likely to grive the animal cold. Injudicions washing and bud drying are produetive of ruming sore eyes, more esprecially visible in white P'oodles, where the hair is long and wooly, retaining the moisture. Once a fortnight is often cuongh to wash any dog but a white one. Washing has very little effect in the destruction of Vermin. Fleas can lire 
some time under water, which I have often thought only makes them bite the harder and stick the closer, when reanimated from their temporary torpidity. If "Butler's Mange Liniment and Flea Exterminator" cannot he obtained, the animal may be well sodden with solt soap and washed about ten minutes after. 'I'his cannot be done with safety, except in warn weather, In cold weather, the comb may he used. immeliately after the application of the soap, as the fleas will then be too stupid to eflect their escape. "Butler's Liniment" destroys all rermin instantaneously, without risk of injuring the animal, and the quadruped may be riused one minute after; no flea will remain alive; the skin will be thoroughly cleansed and the coat heautilied. Dogs should never be allowerl to suffer the torment imposed on them by these detestable rermin. If the owners could only realize the importance of ridding them of these ever noisome pests, there would be far less of snappishness, mauge, fits \&c. I lave scen animals literally worricd to death by fleas, perfectly exhausted, from inces. sant irritation, at last worn to a slieleton and gradually extinguished by a creeping consump. 
tion. Jesides, who, for his own personal comfort), would not rid his immediate vicinity of a worthless mob of blood-suckers awaiting the first firrorable opportunity of regaling themselres on human blood. If your dog lio on straw, burn it once a week, as fleas har. bor and propagate in the tubes of the straw. If the bed be carpet, or anything similar, let it be often cleansed or changed. Vermin revel in filth, and their extirpation depends mainly on cleanliness.

By attending to the general health of a rlog, much discase may be avoided; inkeer, this is fur more essential than prescriptions for a curc. It is very easy to carry off a slight in. disposition by gentle purgatives and a reformen diet; whilst confirmed disease is often difficult to combat, as few of the eaniuc race ean have the adrantages which are oftimes cssential to their restoration. 'The eyes, the nose, the gums, the hair: the breath and particularly the character of the stools should be carefully noterl. The eyes may be red ol pale, sumken or protrud ed ; the nose may be hot or dry or matted with dirt; the gums may be pale, \&c. It will require bnt little experience to discover a disorganiza 
tion, which may be easily detected by him who has noticed the healthful appoarance of the different parts and their variation under indisposition. When the bowels are swollen, it is generally an indication of worms, especially in puppies. who. if they are not attended to, may drop off. before they reach their fourth month. If you are in the habit of keeping your dog on the chain, let him at least run a few minutes every day. If he be kept in doors, he should also be al'owed a little daily exercise outside. Clrange of air and diet will sometimes renorate, when all remedies fail; a change from city to country, from greasy meat to fresh milk, trom a confuned yard to the green fields, where he will generally recruit himself without the aid of medicine. Nature, (to whom Physicians are so deeply indebted for so many wonderful restorations), often effects a cure unaided, which might have defied the efforts of Apothecary's Hall. In summer, particularly, be careful to provide a supply of fresh water and a cool shelter from the sun. Never take your dog out, during the intense heat of the day; this is very apt to produce fits, often resulting in sudden death. Farly in the morning is preferable 
for summer exereise. 'The kennel should be located in a shady spotduring the summer ; in winter it should be sheltered from the wind and so placed as to enable the dog to enjoy the sun shine, at will. Ahove all things, never chain a dog, where he cannot screen himself from the sun's rays. He must have the option of sun. shine or shade; he should not be allowed to drink watcr, that has been standing in the sun or is otherwise damaged. If you should chance to forget to feed him for forty-eight hours, he would not run as much risk of injury, as during three hours of thirst, in hot weather. The best and cheapest dog-house may be made from a common packing-case; it will require nothing but a round hole, about six inches from the bottom, made just large enough to armit of the passage of the tenant; a frame with suffici. ent pitch should be made over the top, to be shingled or boarded for a roof, which should project all round, as much as convenient, to shelter the animal from the sun and rain. If the back or front part only, under the roof be enchused, it will answer as a convenient depot for chain, collar, whip, comb, brush, modiçine, \&c. There should be a piece of joice under 


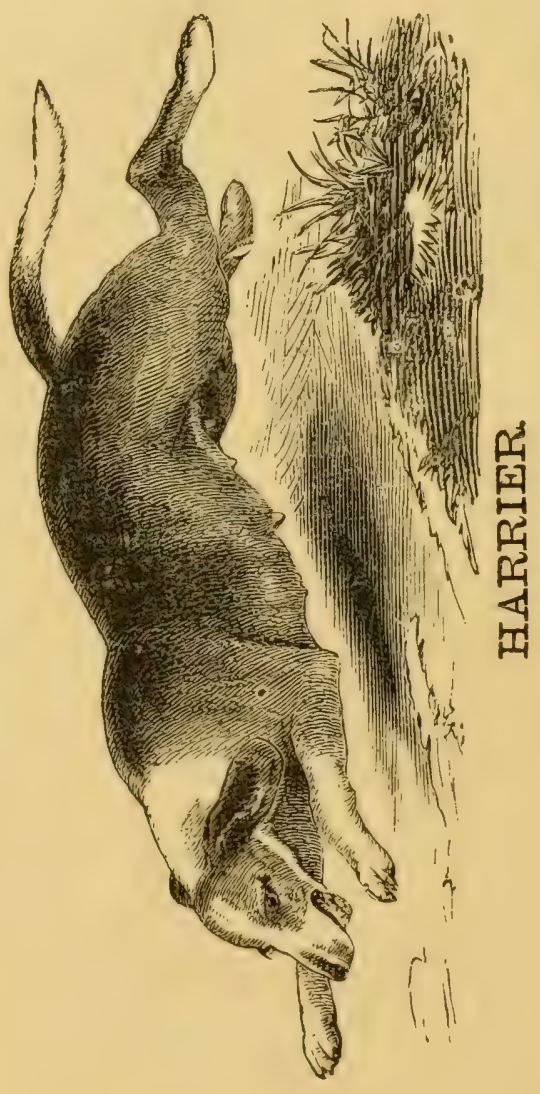




\section{HARRIER.}

Favors the Foxhound and the Linglish Beagle, Just as the hawk resembles much the cagle ; Tho well known Harrier, pride of wealthy squires,

No hunter but his sportive stock adnires. Foxhound in color, but less high in limb, Less elegant, less daring and less trim; Of like endurance, not so swift of font, Of equal seent and cooler nerre to boot; Well disciplined and maniserly, in fine, No hunger tempts him on his game to dine; but seized his prey, by long exciting run, Restrains his appetite and feasts on fun. Hie to the fichls and scan the marshalled corps, Of eager Harriers, forty, p'raps or more ; Onward thoy rush, when Pussey lents the way, A way they stride, with mellow notes so gay ; While country bumpkins from the village erowd 'the neighboring woods, and shout with voices loud ;

Ascend the hill, the glad'ning hunt to view, Again, again, their boisterous shouts renew. Lo! here she comes, the fleet but jaded hare, Struggling to gaia some dark secluder lair, Now closely pressed the lounds their prizo must gain,

Wlen Lepus springs in safety up a drain. 
cach cud of the house, to keep it off the ground, is order to aroid dampness. In summer, an excaration, two or three feet in depth, should be made under $\vdots$ t, and open at both ends, that the animal may have a cool retreat, during the heat. Those, who do not object to a trifling expense, may have the house posted on a large paring-stone, with an cxearation under it, as before recommended. All burrowing animals seck the earth in hot weather ; everything on the surface is heated; their instinct dictates to them the most reasonable method of sheitering themselves from the heat, at the same time. absorbing the cool cxhalations from the ground. In southern climates, especially, this methor is all important. In this manner, I liave kept dogs from the polar regions, in comparative comfort, whilst many native-born and nerlect. ed have been scalded intolits, paralysis, rabies or hydrophobia. In the hot season, with young dogs, raw meats should be aroided, except it be quite fiesh, and then it should not be orer fed, especially to animals, who are debarred abunclant exercise and excluded from their own ratural medicine : grass. Neverthcless I have not perceived any evil effects from the moth. 
crate fecding of fresh sheep's heads, tripe or even entrails to animals of sufficient age and strength. A dog will thrive better on raw meat, than on any other food, and will grow larger: but he should be fed with discretion, and his health attended to, should his dict visibly disagree with him. He will trow fatter aud be more healthy on moderate meals, than to be ovelgorged. 'The better plan is, to ascertain his average consumption and then allow him a little less. Keep his digestion in good order, and disease will rarely trouble him. His coat and ribs will generally indicate whether he he sufficiently cared for, whether he he sick or sound in his digestive orerans. Feed him always in the same place, and at the same hour. Once a day is sufficient, if he be over six months old. By being fed only onee a day, he is less choice, and will consnme what he might refuse, if his appetite were dulled by a previons meal. Hould yon require him to be watchinl at night, feed him in the morning ; if you wouls? have him quiet at night, feed him late, and don't leave him bones to gnaw. Dogs are pretty quict, during the digestire process. whes left to themselves, and sinuld not have muh erer. 
eise, after a heavy meal. They shonld only bo lightly fed, before training-lessons, or on sporting-days; on the latter occasinus. a little refreshnent may be administered as occasion may require. Those kept in doors should be allowed to run a little after meals, when they generally require an eracuation. If a dog be revularly exercised, he will seldom eren dirt around his kennel, and a heaitly louse-pet is rarely tronllesome, except aíter eating. If a dog be dirty in the house, he should decidedly he broken of it, although he should not be colrected, unless he has had a fair opportunity of aroiding it. He should be invariably taken to the spot, be sufficiently iwigged there, and unceremoniously scolded into the yard. It is important to catch him in the act, and administer summary chastisement. The punishment will be far more justly administered, if the animal be let out at regular intervals; this being done, he will not attempt to infringe the law, except in cases of dire necessity. Young puppies however, nust be, in a measure excused or mort gently corrected, as they are incallable of' selfrestraint. Nerertheless they may be very carly initiated into habits of eleanliness. i 
Dog is often spoiled, by being caressed iny hundreds, and kicked by scores; either painpered by all, or fed by none; either constantly bound with a cramped range of a few feet, or left to ramble undirected, through the streets. IIe should have but one master; should not be rendered sullen and surly, for lack of associating with his superiors, neither should he be allowed an enlarged acquaintance, especially in his own neighborbood; as it will tend to render him listless as a guardian, and perchance too familiar with some, whose presence, it might he the peculiar interest of his master to aroid. Although there is as great a rariety of talent and disposition in $\operatorname{dog} s$, as in mankind, yet we can almost mould them, as we please. If they be too savage, they may be softened down by accustoming them to a variety of faces and friends; and correcting them in their fiery ebulitions. If too meek, their diopositions may be roused and their dormant passions excited; solitude, encouragement and occasional irritation may be resorted to ; in fine, a tame listless temperament should be cantiously handled, yet continually fed with gentle irritants, and the animal will not long require smarting up). I 
in is have reduced the sarage bull-dog to be as tractable as a hand organ, and hasc made the gentle Spaniel a thoroughly ficree watch-dog. We must use firmness, without severity, except in cases of conscious misdemeanor ; pass no doglaws which we are not at all times prepared to enforce; never punish for a fault, un'ess we are perfectly satisfied of guilt; allow no one else to correct, unless urgent necessity rlemand it, and never allow the fire of our imagination to inflict more than deserved punishment.

Pups should be cantiously corrected, and although their obedience must of necessity be enforced, as early as they can distinguish between roast beef and stale brear, too much should not be exacted from them, and no screrity used; as it may have the effect of cowering them down, thus materially effecting their pluck and spirits in after life,

I an satisfied as a general rule, that a well amalgamated mixture of animal and regetable, is the most healthful diet, for dogs of all ages, breeds and conditions. Dogs living in the house should on no account be fed on raw meat, as it gives them a very offensive smell and is in other respects very unsuitable. 


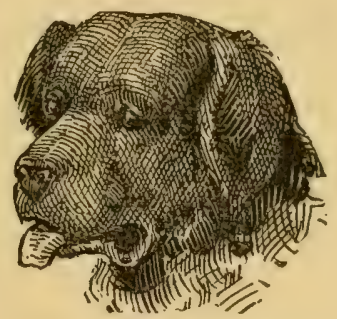

MEETHING, TEETH ko.

A Great deal of stress is lavd on the teething of dogs. About this period, Nature appears to be undergoing a certain change, and a dog is in less dauger from dying from Distemper, after the operation is thoroughly effected. The animal of course becomes stronger, as he gets older; consequently the better fitted to withstand disease; otherwise the simple act of teething, I cannot imagine to effect materially the general health; although from the great excitability of delicate breeds of dogs, fits may he often attributed to the annoyance occasioned hy the process of dentition. Until the teeth be fully dercloped, the animal will require more than ordinary care and attention. His stomach should never be overloaded, yarticularly with 
maxt or any gross food. Of light fare however, he mav always eat to the full, and his strength should be maintained by gencrous living. It is said there is great danger, should a puppy happen to swallow any of his teeth: For my part, I do not believe in any such nonsense, and should not be afraid to give a dog half a dozen with his dinner; I am satisfied there would be no fatal result. It may be advicable to remove some of the first teeth, should any be in the way of the second crop, but I seldom see any occasion for it, except when they are quite loose, or interfere with the new-comers. Giv. ing medicine to $\operatorname{logs}$ simply because they are shedding their teeth is quite unnecessary. Should they be fererish or indisposed, it would be expedient, otherwise, Nature had better take its course. Dogs are apt to get cankered teeth, especially when attacked by Distemper, during the teething process ; therefore exposure to this latter disease should be avoided as much as possible, until the mouth is fairly furnished. The teeth often become foul and incrusted with Tarter. This arises cither from gross feeding, the results of Distemper, or a disordered diges- 
tion, and is sometimes lereditary. Any gecd tooth-powder may be used and they may bo cleaned with a brush. The ashes of burnt iread are about as good as any thing for cleansing the teeth, and in no wise injurjous. 'T'he teeth may be scraped, if necessary; but it sliould be done carefully, so as not to disturb) the enamel. An occasional scrubbing with rinegar tends to sweeten the mouth and is excellent for cleansing the teeth. I do not imasine howerer, that cleansing the teeth will effectwally cure fetid breath. It certainly has a grood efiect, but the stomach is more the seat of the affection, and must be kept healthy. Deeared teeth should be extracted as they rencer the breath very offensive. An auimal with finl hreath should be allowed but little meat. and be occasionally treaterl to a yentle purarative. Without attending to this, the teeth will soon become recoated, and the breath remain but little improved. For the age of a dog; we generally look to the teeth, but this is by no means a decided test, except porhaps at ages undicr two years. A five year old $\operatorname{dog}$ may perhaps have a better mouth than others of half his age. Nevertheless a young dog 


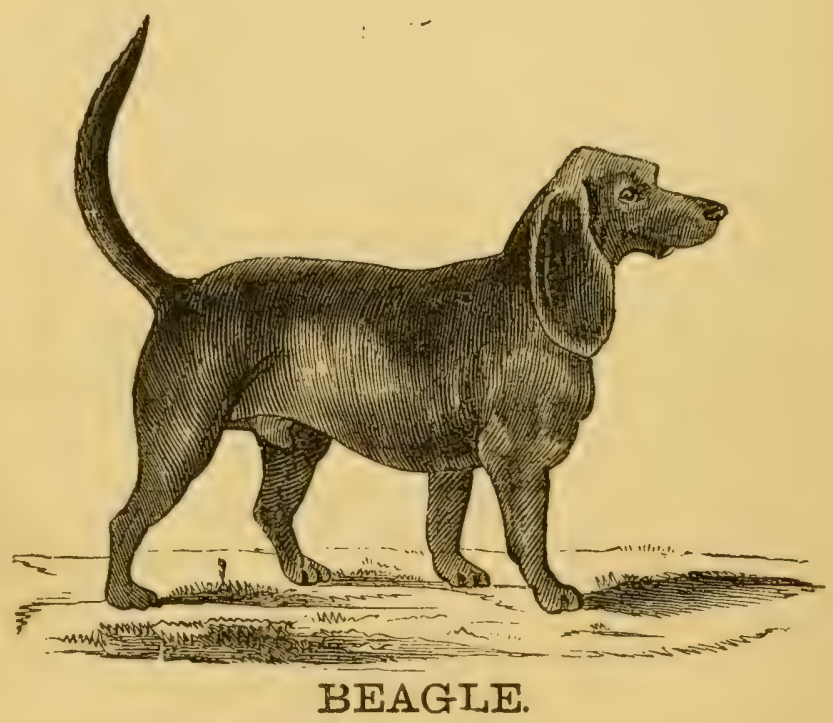




\section{BEAGLE.}

With ears of Hound, and Turnspit limb to hoot, The gouty sportsman most inclinel to suit ; M ust some relation to the Turnspit be,

Eilse none with back, so long and low as he: Black-tan, in color, tho' not ever so, With Connoisseurs, the former all the go. While yet the smallest of the hunting class, But few his slow activity surpass;

Ilis watchword "Onward," tardy tho" his pace; IIis motto : Slow and steady wins the raciso" Rabbit or hare, in covert. apt to dodge, From sheltered wall or thicket to dislodge, And luckly after many a sinuous run, Presents the rictim to the fatal gun.

In slower times, in England widely knora; ()f late, in Germany, more often grown.

When Hawk and Beagle graced the liunting field,

'Ere yet the sun the pearly dew revealed, In days of Wassail and of good old Sack, Away they sped, the merry tuneful pack. The lusty Baron, and the portly Squire,

'.'h' embroidered Lordling and the bloated Friar, In concert joined, to greet the rising morn, 'The gladdening echo of the inspiring horn. 
TEETHING, T'EETH, \&C.

may generally be distinguished from an old one by the lack of wear in the small front terth. and from the clear whiteness of the teeth in gencral. 'The small front teeth are the first to grive way: indeed some dogs (those of the short-nosed breeds cspecially) are apt to lose them at a rery early age. If all were fed alike the teeth would mole farly incleate the years, but an animal, who has had to grind bones for a living, will file of more irory in three days than the ordinary wear and tear of a decently fed animal, in a year. Long-nosed dogs generally have the best, the longest and most durable teeth, whilst the small front teeth of the snub-nosed are set so lightly in their sockets. that they are easily dislodged. 'This is more peculiar to Bull-dogs, King Charles' spaniels and Pugs. 'Those fed on warm food and furing principally on rich meats will show early symp. toms of decaying tecth. Close confinement. lack of exercise and a too nutritious dict tend to destroy the healthy tone of the srstem, consequently must be injurious to the teeth. Fetching stones is the most injurious of all things and should nerer be permitted, as it not only destroys the teeth, but the animal who is 
TEETHING, TEETH, \&C.

allowed the pastime is generally at the beck and call of every one, makes a periect fool of himself, and will own any one tor a master

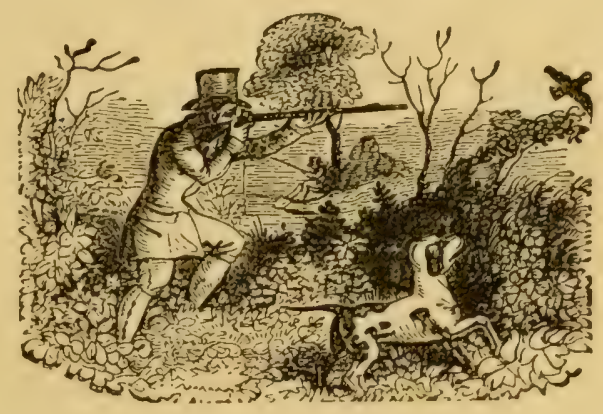




\section{CROPPING, TAILING, DET-CLA WS.}

Tre dog-fancying portion of the community are so accustomed to the cropping of Bull- $\operatorname{logs}$, 'Terriers, Bull-terriers and others of the pugnacious class, that the public, through them, have become conrinced that the operation is absolutely indispensible.

The practice originated in a desire to save the ears of the animal from being lacerated and torn, and to prevent them serving as a hold in his warlike cucounters with others of the same stamp. It is decidedly an injurious practice, often producing hardless of hearing, if not deafness, by exposing the ear to the reception of all kinds of filth and tending to produce disease. I certainly am accustomed to think it improves the appearance of some breeds of $\operatorname{dog} \mathrm{s}$, but I believe they would be less punished, cren in a fight, with their ears on; as the bite 
on a short ear would consequently be nearer the head, and on that a ecount the more punishing. As for their being torn by thorns and otherwise damaged, the flaps are the greatest protection against all internal injuries. The method I adopt in cropping. is first to cut the top off one car to the desired length; the piece taken off to be used as a measure, by which to cut the other top. When both tops are off. flatten the car out with one hand and cut in a straight line from the base of the ear to the farthest point at the top, cutting of course both ears exactly alike. Do not cut too close in at the base, if you do not wish to subject the dog to great discomfort, for the sake of fushion. There are various methods of cropping, but whichever you adopit. be careful to cut both ears exactly alike, or the beauty of the handsomest animal may be ruined for life. It should he done with a large shary, seissors, so as to be effected with one cut; thus it will be better done and give the animal less pain. But never attempt the operation, unless you have a steady holder, as on this depends perhaps more than on your own skill. If the ears should be left long, or appear to be inclined to droop, they 
may be tied together for a few days, over the head by a piece of thread, passed through the ends of the ears with a needle. After the operation, strong salt and water will stay the bleeding and stop the smarting. A little olive oil mav be afterwards put on twice a day, with a light feather ; but the ears will do about as well, if let alone. Some advocate the cutting of the ears, when the animal is only a few weeks old, True, they very soon heal under the mother's care, and the sooner on account of their tenderness, but I prefer waiting till the dog is four or five months old, because the ear is not developed at such an early age; therefore in its growth, it becomes naturally thick, and seldom looks well; in the second place, before the ears be cut, the natural droop has to be considered, and they should be shorttened accordingly, or they will never stand up right. Besides in case of sickness or more especially Fits, it may he adrantagcous to have ears to cut off, to reliere the flow of blood to the head. As to tailing, it is a very simple operation (now almost out of fashion) and requires nothing but a knife or any sharp instrument, with which the norrative may be abtreviated 
CROPPING, TAILING, DEW-CLAWS.

to suite the taste of the owner. It is far pref. erable that this be done when young, as the tail is more difficult to heal than the ear. 'To stnp the flow of blood, if necessary, put salt alirl rinegar in a rag and tie it orer the end of thr tail. There is no need of this, when the animal is rery young; when more matured, how. ever, I have seen several instances, where the animal would have bled to death without it. If you cut it when young; take care not to leave it too short, as it will not grow in propor. tion to other parts of the body, and a short stump is a most inelegant appendage to the most symmetrical form.

Dew-claws are considered by many as a proof of impurity of breed. I see no ground for such a supposition, as I have found them occasionally on all breeds, good, bad or indifferent, and I must say I cannot account for their appearance. They may, howerer, have once been the distinctive mark of a pure stock. Those who have any objection to them can easily remove them with a sharp scissors. They are generally very lightly attached, and the pain nust be very trifling, especially when the ani mal is young. 


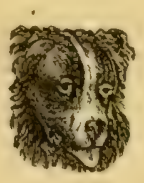

CASTRATION OF DOGS.-SPAYING OF SLUTS.

Cistration is one of the most simple onera. tions. requiring nothing more tlan a sharp knife, a steady hand and a little experience. The most suitable age, I consider to be from five to nine months. For this operation, the animal should be made perfectly sccure, by one person holding his head, and a second the legs, whilst the hands of the operator must be perfectly free. If the dog's head be put into a bag, or be otherwise covered. he will be far less restive. or perhaps wholly unconscious of any danger. For all painful operations, a dog should be blinded; it will detract greatly from his nerrous restlessness aud matevially facilitate the process. The skin at the base of the testicle should be firmly held between the thumb and finger of the left hand, so as to 
present a fair tightened surface; then cut through the skin just decp enough to expose it to view. Whilst you still hold perfect?y fast will the left hand, draw out the testicle, string and all with the right. Should it be dificult to draw out, the knife may be passed round it, to facilitate the extraction, but if the operation be performed at an early age, this will seldom be requisite, as the pressure of the thumb and finger will suffice to foree the testicle ont so as to present a fair hold for the right hand. Should the string not draw ont, it may be cut off; of course each must be taken ont separately ; the same means used in extracting the first, applies also in the second. The operation should not be performed either during rery warm or cold weathe:, unless the animal can be kept in a somewhat moderate degree of warmth, for at least a couple of wecks. No after.apulication is required, other than washing the parts, with strong salt and water, immediately after the operation. and a little lard or goose-grease, to soothe the irritation. The dog should be kept cool, quiet and cheerful; his food should not be gross, and he may requre a little cooling physic. He should be exposed to no extremes 


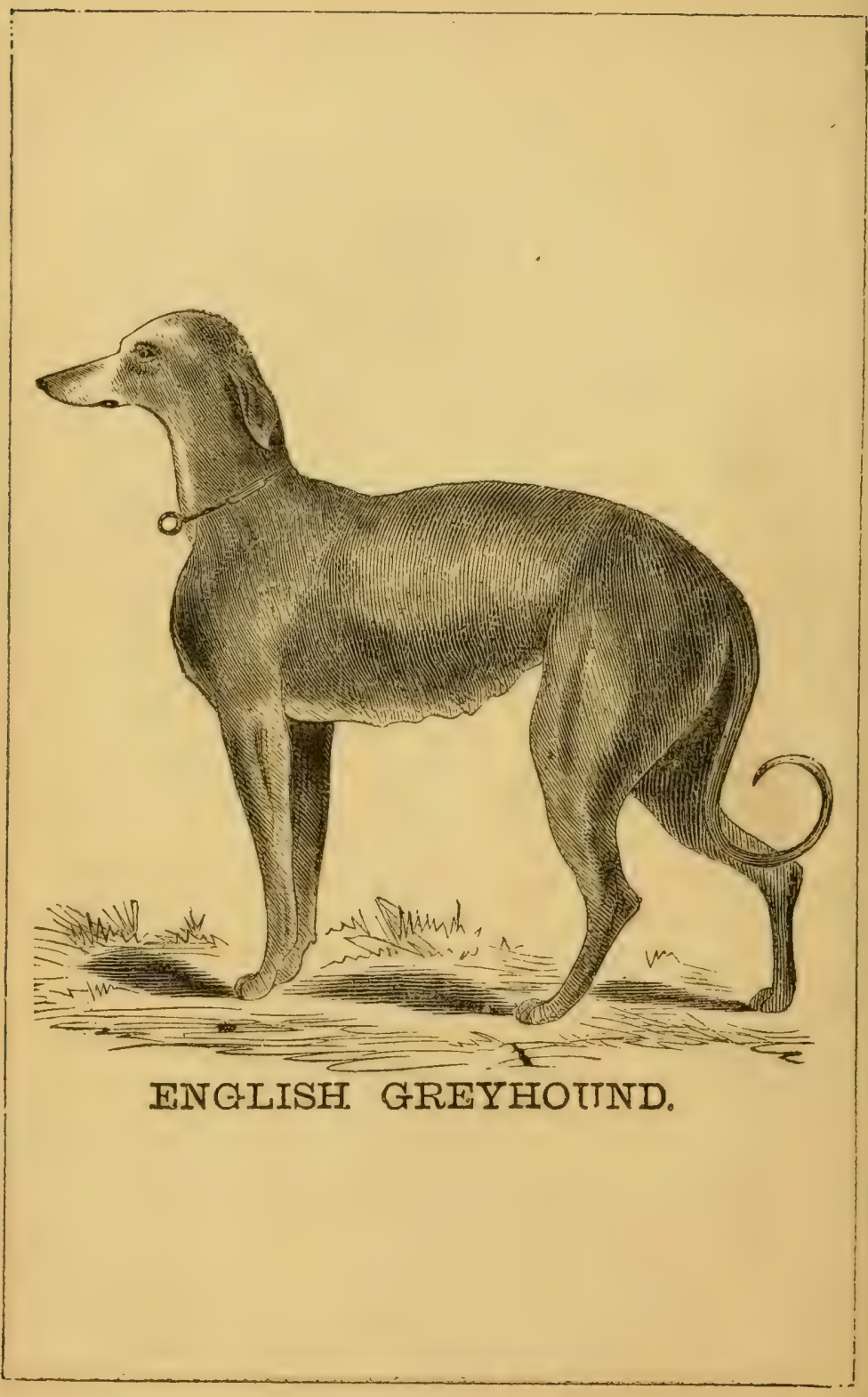




\section{FNGLISH GREYHOUND.}

ITis sinewy limb, gymmetric form and grace, $V$ ie with the hind, and equal him in pace ; Elastic, bouncling o'er the flowery meal, Unmatehed his spring, agility and speed. Ifis culor hlark or white, red, bluc or grey; The latter, the original, they say ;

1.oir tancring nose small ear and piercing cye, II s destined game uncrringly desery.

With common hound, disdains to secnt his prey ; By sight alone, he speeds his light'ning way; The trembling hare, for safety flies in vain, An! fruitless secks the shelt'ring copse to gain. On Alhion's shore, where hunting is the rige, His feats and pedigree grace every page ; Grandsire and Granilam, all is there recorded, And to the fleetest, is the prize awarderl. If ought impure, in blood or limb, we trace, His name's ignored, excluded from the rave; Condemned a Lurcher, fit for Poacher's gyime, But for the nobler sports, despised his mune. And many a liero, famed for martial dceds, Vaunts his fleet greyhounds, and his rampant steeds;

And when in giee, the sparkling wine they sup, Points to Diana's prize, the "Golden Cup." 
of either heat or cold, be allowed very little exercise and be kept in a perfectly clean place, that no dirt may enter the sore. The charges produced by this operation differ in different subjects; as a general thing, its results are fat and a lazy independence, and of course in all cases a perfect indifference to the charms of the other sex. I am inclined to believe that if these altered subjects were not allowed to get too fat, they probably wnuld retain more of their natural vigor. I am far from believing that it detracts either from their sagacity or intelligence. I have seen several cases, where it has added to their pluck and daring. These may be quoted as exceptions. They are decidedly less inclined to roving; are more cleanly in their habits and the more casily recorered, if lost.

The Spaying of Sluts is not much practiced now-a-days. The effect on them is about the same as on tine male. I hare wituessed the operation, but have nerer performed it. It consists in making an incision in the flank, and extracting the ovaries, which renders the animal incapable of producing young. It requires a practiced hand to ensure success; I shall therefore not enlarge on the subject. 


\section{DOG-TRAINING, TRICKS, \&O.}

\section{INTRODUCTORY REMARKS ON THE TRAINING OF DOGS.}

Oxe might suppose from the surprise and aston. ishment expressed, on the relation of examples of the extraordinary sagacity, instinct and reasoning powers of the dog, that these gifta were bestowed by Nature only on the favored few ; whilst the majority of canines were far beneath the level of ordinary brutes and actual. ly incapable of instruction, denicd the privilege of ranking among their more favored brethren. This impression howerer is not altogether groundless, considering how few persons there are, who take into consideration the evils, to which they are personally subjected, through the lawless multitude of untutored quadrupeds, with which the whole country is infested, or who pause to imagine the benefits which might revert to themselves, did they contribute their * 
H.are, towards ameliorating the condition of animals, who are erer willing to serve and doubly blest in obeying.

Mr. Smith envies Mr. Jones, betause Mr. J. is the owner of such a well-behared, intelligent, respectable $\mathrm{log}_{\text {, }}$ and wonders where lie got the breed. Mr. White can't imagine how his neighhor Green could have taught his dog so many curious tricks, and is anxious to get a puppy of the same stock. which of course he expects will educate himself, at a very early age.

$\mathrm{My}$ object is to prove that it requires but a small amount either of time or labor, to rescue eren the meanest mongrel from a life of degradation and misery and place him in a position, where he may be respected for his virtues and appreciated for his worth.

The most important points to be considered in the training of a dog are first: to under. stand somewhat of his natural disposition and tempcrament. Secondly: not to exact too much of him at once. Thirdly: to use as lit. the force as possilile. Fourthly: always to in. sist on obedience and never to pass unnoticud the slighest act of insubordination. Fifthly : begin your instructions as early as possible. 
(The pup is never too young to learn, especially to do wrong, if left to himself.)

The principal causes of so many dogs being epoiled in the training may be traced to their laving been taken in hand too late; having had too many masters, from the indecision or sererity of their instructors. The moment a $\mathrm{dog}$ is known to fetch, three or four objects are thrown at once, and every acquaintance amuses himself in putting the abilities of the animal to the test ; he is consequently puzzled, considers it only a play-game and becomes remiss in his duty to his master. Just so with any of his other perform. ances. He is perhaps allowed to follow a variety of persons, which often tends to lessen his attachment and obedience to his real owner, at the same time allowing him fuvorable opportunities of committing a variety of acts, which he dared not dream of, in his master's presence. A dog then to be rightly trained, should be under the sole management of one person; he should be allowed to do nothing without his master's knowledge and consent. He should be expressly habituated to all kinds of company. hogs, cows, dogs, goats, sheep, chickens, \&c., so that he may be firmly checked by lis master, 
should he attempt any wanton attacks on others of the animal kingdom, at the same time that he may be taught to rid himself of all fear of their presence by occasionally associating with them. The earliest impulse of a canine, that has any pretension to pluck, is to attack the first animal he sees, whilst all dogs, either with or without evil intent are inclined to pursue every living creature that runs from them. This inclination can either be encouraged or checked, either speedily annililated or cultirated, to suit the will of the trainer ; therefore it necessarily follows. that as soon as a dog has a will of his own, it should be well directed or immediately curbed. If he be old enough to eat, he is old enough to be made to let it alone; if he be old enough to come when called and go away when he is bid, he is also old enough to know his place, and be made to stay there, till he is wanted, (at least in his master's presence.) But in these carly lessons, we must be extremely careful to keep in perfect good humor, and to let our punishments be very light; as there is not only great danger in forcing too much on weak intellects, but in inflicting too much on youthiful pets. Let your lessons be light, easy, 
short and pleasant. If your pupil tires, adjourn the meeting. By consulting his feclings, he will be more apt and willing, will delight in your teachings and long for their repetition. Half a pound of encouragement, two ounces of decided disapproval, a quarter of a pound of patience and two ounces of gentle correction, form an excellent mixture as a basis for canino instruction. I have trained many dogs for my own private use, and I confess they have causca ine anything but trouble; they liave been all extremely apt, docile and willing. I do not attribute this to their superior intellectual proportions, neither to any inborn sagacity of my own, but merely to a method of consulting their inclinations and exciting their wills, thus rendering their toil a pleasure, their studies a sport. The teachings, (as I often observe) should be short, often, and reinuar. A quarter of an hour twice a day will be of more effect than two hours three times a week. The best place, (for early lessons especially) is in a yard or moderate sized enclosure, as the animal will be far more obedient, where he has no cliance of escape, and his attention will not be diverted by other objects. He had better also be 
taught alone, until he is well advanced, as I have observed dogs to be very shy at first in performing in the presence of others. The 'Trainer should also appear very joyous when the student does his duty. This has a most astonishing effect; as dogs (being no hypocrites theinselves,) judge entirely from appearances, and look one right in the face, which to them is the unerring index of the mind. When you unchain a $\log$ to give him a lesson, always let him have a good romp first, (if he please), as he will generally he uneasy, if you omit it, consequently less attentive to your instructions. If possible, never allow any one to help you teach him; he will readily digest the commands of one, whilst a second method is apt to puzzle him; besides he will always be more tractable under one instructor, and will far more readily obey the teachings of his master. Any strange system of management will only tend to diminish his attachment and obedience. By these remarks, I do not mean to infer that a man is bound to train his own dog, neither that an animal might not be better educated by two persons, than by one only, who in a measure either neglected him, or treated him improper. 
ly; but, that the animal is the more easily managed, when directed by one head, and own. ed solely by one master. With regard to Sporting Dogs, I consider it advisable that they shou!d be trained rather by regular Sporting men, than to be spoiled by a youthful Greenhorn. A regular Breaker is better enabled to give him constant practice in the field of his future labors, than the occasional Sportsman, in whose keeping he may become addieted to bad habits. Another thing, he should, if convenient, be raised in the country, where he will become more healthful, vigorous and har$d y$; that is to say, unless the owner should have other means at hand of securing to him that sanitory exercise, indispensably necessary to his perfect physical and mental development. Dogs in some respects are like children. Show me a dozen genteel children raised in the city, pampered with delicacies, exereising themselves in the nursery, carefully cloaked and india-rubbered, on the slightest fall of the barometer, thus fattening the Doctor and Apothecary at the expense of their delicate constitutions. Compare with them a dozen Rustics. Who will throw a stone the farthest, climb a tree the 


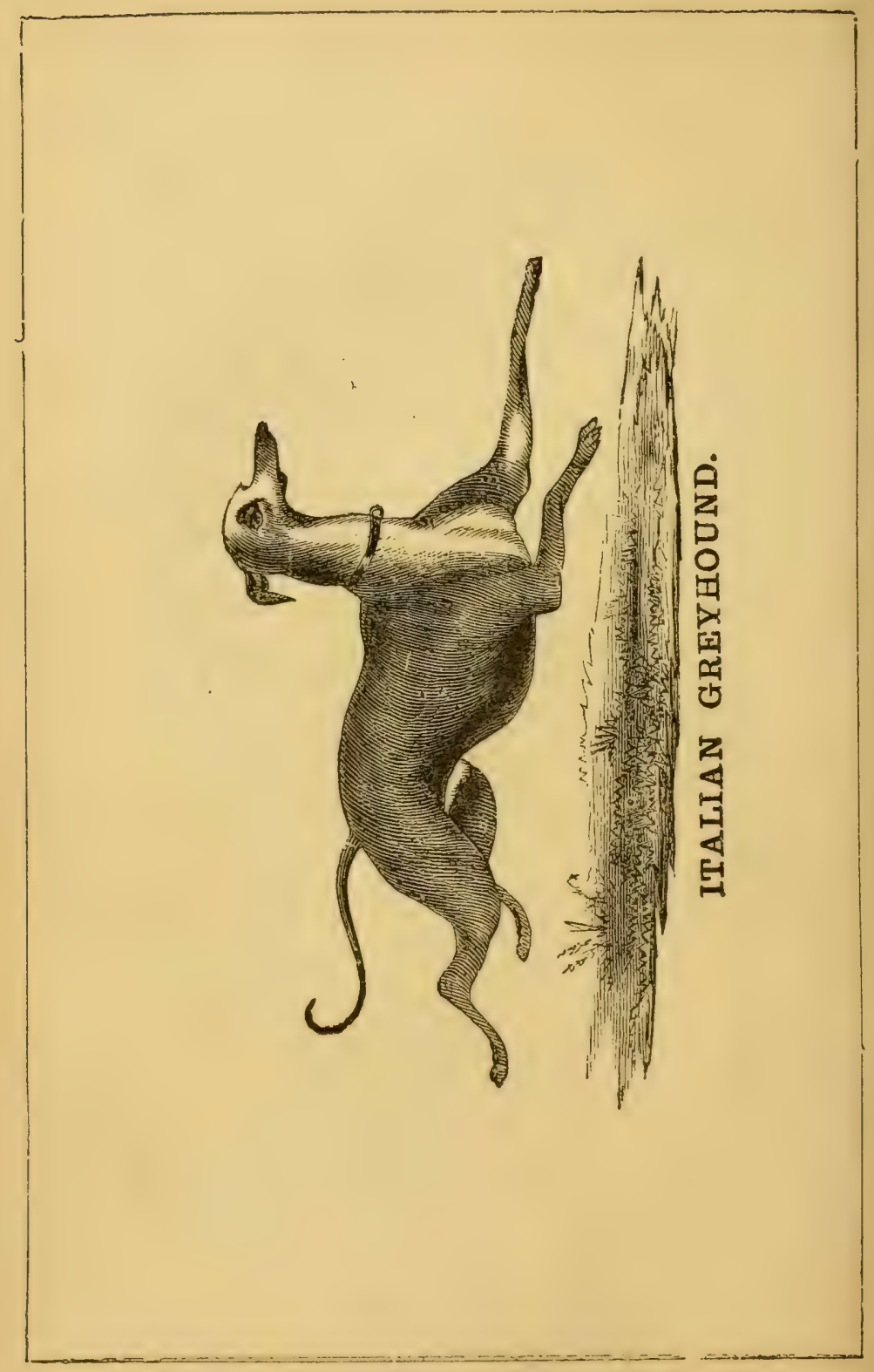




\section{TALIAN GREYHOUND.}

Molel of beauty, Eymmetry and grace, From fair Italia springs thy sylphlike race; siwcet emblem of the clime, that gave thee birth, Symbol of action, sprightliness and mirth! like his famed compeer of the nobler grade, Of different color, and of varied sliade; Matchless in mould, of fawnlike form and limb ; Small silken ear. soft, light, transpar nt skin, Fitted alone in genial warmth to dwellGentecl appendage of the flaunting Belle. His magic trip and quick, elastic bound, Disgrace the awkward step of meaner hound ; The gay attendant of the proud and fair, 'To doubt bis use or merit none shall dare. 'The maiden's nursling and the bride's deligkt, Fondled by day, and feathered up at night; For ruder sports, inapt his slender form, Yet quick of ear, the stealthy rocue to warn, In courage lacking, yet his very fear

IVill rouse the house when thief or burglar's near.

Then wonder not, a pampered hound like he, So delicate, effeminate should be ;

His graces cliarm, nor let his faults perplex, Since he was framed to please the gentler sez. 
quickest, or stand toil the best? Just so wit! animal nature in other forms. Again, I repeat, wholesome foo l, plenty of air and exercise are the principal ingredients necessary to fiane a ha: $d y$ and enduring constitution, and the safest antidotes against degeneration and disease.

\section{DOWN! STOP! STEADY THEFE！}

Down! Gently press the dog down, repeat. ing "Down! Down Sir !" hold orel him a twig or a whip ; if he resist. (as most probably he may,) use the whip very lightly, and increase in srerity, according to the obstinacy of the animul, whilst you carefully exhibit firmuess without anger. As soon as he has remained "Down" about half a minute, do not omit to encourage and play with him, give him a little rest, and repeat. As soon as you see he understands it, make him perform without the sign of the whip, raising only the hand orel him. (The whip may be concealed in your pocket. and produced in case of necessity.) When he lowns without threatening, try him at a little 
distance fiom you, (say six feet). If he rofuso at that distance, approach him, administering a little corrction, and repeat, till a polite request be sufficient to enforec compliance. Ie cautious not to weary him, by repeating th? same thing too often. Change off to a fetching, or a:ly other lesson. Keep up his spirits. by constant encouragement, and appear to join in the fun, though always maintaining your authority. Whon he downs short at six feet, or at any distance fiom you, change your command "Down". to "Stop! Down !". The hand uplifted the same, and go on increasing the distance, little by little, always enforcing the "Stop" till it becomesinstantanerus. Continue this, till he is perfect at a distance, equal to the full extent of your voice. When he is in 1notion, omit now the word "Down," and only use "Stop)." 'This being effected, accustom him to stop, when he is on the full run; throw an olsject for him to fetch, and occasionally stop him short, when at the height of his speed. Then set him at some animal, and before he quite reaches him, check him short with the "Stop)." Don't weary him by a too of repetition of the game thing. The next thing is to make him 
stay, under the word "Stop" till he is permitted to more; and he never should at any time be allowed to stir. unless invited by the signal "Up." At first, of course, a very short time must be exacted, (say half a minute) at the expiration of which he must be released by the sigual "Up" accompanied by raising the hand, invitingly called away and encouraged; but he the time erer so short, he must nerer be allowed to leave of his own accord. By gradually increasing his time, and unerringly enforcing your orders, you may erentually succed in keeping him there for hours, if you wish. I have occasionally forgotten my own orders, and have found my faithful dog, true to his jost, lours after the command of "Steady there" was issued. This is the word now to be used. Renomber then "Down," "Stop," "Up" and "Sicudy there."

\section{CONE IN ! KEEP IN! GO ON!}

UxLess a $\operatorname{dog}$ come, when he is called, he is not to be depended on. He may be tempted either for sport, malice, or pastine to pursue a 
cat, hog, dog, \&c. ; worse than that, he may bo inclined to dodge after the opposite sex, regardless of his master's commands, deaf to his threats and entreaties. As a barrier against such casualties, he should be strictly taught to come immediately at call. Now this cannot be classed among dog-ricks, but perhaps it is more difficult to teach, as it requires considerable judgment to enforce, and often great patience to forbear. A dog must be taught to come, with as little threatening as possible, especially when he is at a distance. as young dogs may casily be too much intimidated by threats. When a command has to be obeyed at a distance, its execution depends principally on the animal's will. He should then be humored, until lie thoroughly understands his duty, after which he will bear such seasonable correction, as the case may require. He should be regularly drilled into it, at gradually increasing distances. A beckoning sign should also be made accompanying the command, or a peculiar whistle used, more particularly if he be a sport. ing dog, who may be often out of sight. It is conrenient that he should understand both sign, voice and whistle. His obedience should bo 


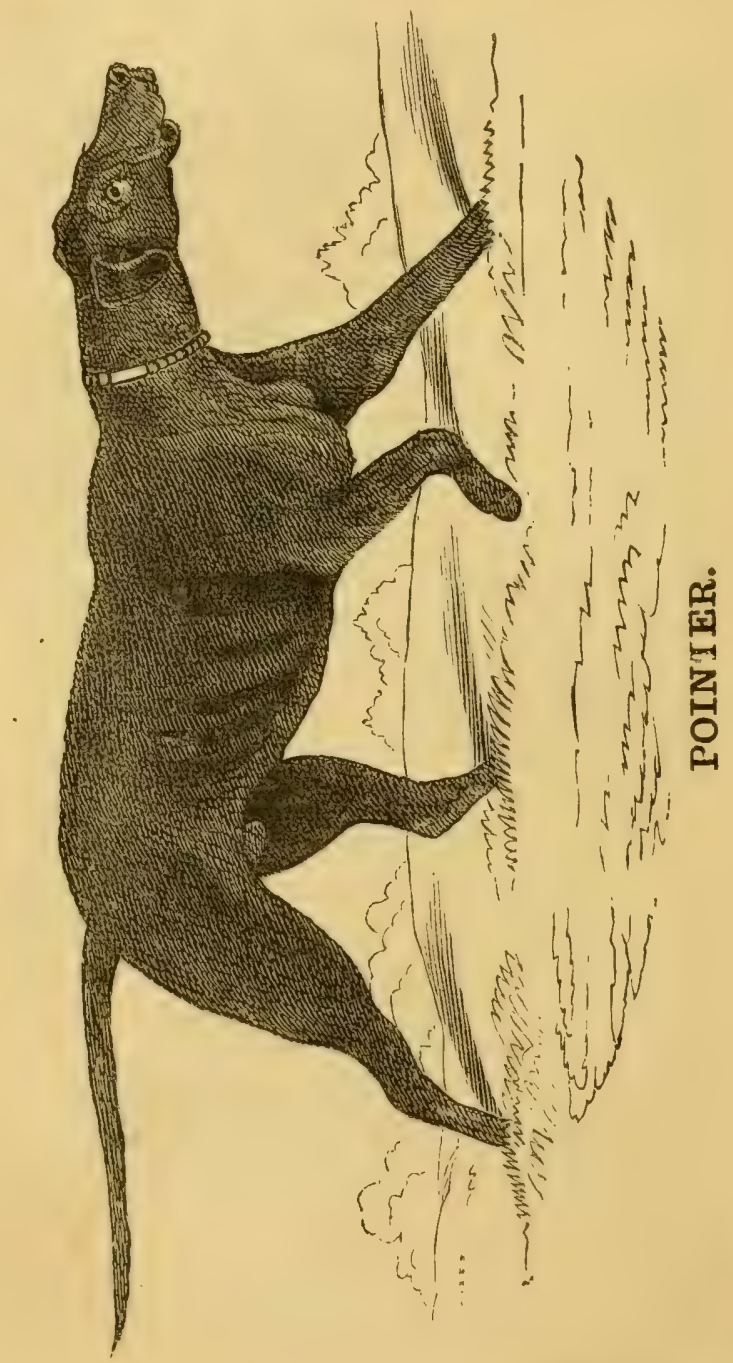




\section{POINTER.}

In color, size, to Setter most akir ;

With him contends Diana's prize to win ; Of for'm more elegant, when highly bred,

Smooth drooping ear and intellectual head ; (f) nervous build and muscular in limb,

Clear, close set coat, with tail, long, straight and slim ;

In Englun I,Scotland, Ireland,France and Spain, Varying in leature, yet in worth the same; By some, the setter is the worthiest deemed; By other's, Pointers are the most esteemed; But, 'ere deciling, we should tirst compare Climate and treatment, manarement and fare. 'The former thickly clad, by Nature warm, Adaptell best, to orave the cold and storm. 'T'hr, ugh bush and bramble, fearless cleares his way, I)eep roshing waters must his steps oher; The Pointer flags nol, in the burning heat, Nor jadest. pants. the cooling spring to greet; Solely, wholly, purely, all tor lim, His aim is centered, in the double gun. Unlike the Homnd, he hunts not to de-troy ; 'The sportsman's glory is his highest joy ; In fine, in gaming powers, so like the Setter,

$\Delta$ task it were, to nominate the better. 
thoroughly tested in every way, and his habita of willing submission indelibly confirmed.

"Keep in" is also essential to the good man. ners anil safety of your dog. It kceps him from wandering off at undesirable periods, and enables him to wind his way through a crowd, without lusing his master. He slould not be allowed to go on, withont the order "On, Go on." If he should show a determination to adrance, he may be saluted with a gentle tap, to the tune of "In, Keep in!" At first, lie should not be kept in too long at a time, but often encouraged by the word "On." If he refuse to go on, he may be excited by throwing a cracker \&c., a little ahead.

Remember, although he may be forced to come $i n$, it is extremely difficult to force him to go on, until he is thoroughly drilled. This must therefore be effected principally by encouragement and good humor, sometimes by patting and cxciting, or even by adrancing at a quick pace yourself. In all these things, the disposition of the animal must regulate in a great measure our method of treatment. One thing is certain, the more he is pleased with you, the more readily will he obey. 


\section{BHAKING HANDS; HIGHT HAND ; LEFT HAXD; SITIING UP ; STANDING UP ; WALEING ON TUE HIND LEGS.}

Gexeralit, the dog's first act of frieniship is to juit up lis hand to his master. His paw shonld be taken and gently shaken; then the other; at the same time, repeating " right hand" for the right, and "left hand" for the left, always taking tlie one required, and inrariably refusing the other. Your hand should be first extended to the side of the paw demanded, so that the other paw cannot reach it. He will soon become habituated to the words right and left, and immediately distinguish between them. Ife may then be taught (if you please) to go round and shake hands with the. whole company. To make it perhaps more amusing, you may term the right paw the gentlemen's and the left the lady's; or you may while standing up, hold out both your hands, inviting him to jump up. When he has done this a few times, you can, while your hands are out, say "Show me how you shake hands with the ladies" when the act of giring both pans, will be the ansiver. 
To make a dor sit up, he must be placed in mosition, and be there made to sit for a short time and seriously threatened, should he dare to disobey the order "Sit up Siv." Ile must be kept a rery short time at first and his poorest efforts must be flattered. Although at the outset, he must be placed in position, he should soon be taught to rise at a touch, accompanied by the word of commard, and shortly after ly the word alone. A gentle rap on his fore-fect with a twig may be of occasional service. When he answers to the word, you should increase your distance from him, be more perempr tory in your orders, and rather more screre, if he disobey. He may then, at a short distance have a pipe placed in his mouth and a cap on his head; he may also be ornamented with a pair of spectacles, which togetler with a newspaper, placed before him, will render him well worthy of your attention.

As for teaching an animal to stand up on his hind legs, a piece of meat will be found quite sufficient inducement. This is the most natural and simple method of instruction. As he stands up to reach the meat, it should be drawn slowly forward, for him to follow on his 
hind lege, while at the same tine, you repeat "Walk along Sir." You nay find it casier per. haps, to start him from a wall, against which he must be stood upright, and tempted onward in hopes of the meat, of which he should be al. lowed a small portion, whon he behaves well, but never unless to reward him for his efforts of obedience. Of course he will require no regular fee, when he thoroughly understands his duty, although an occasional kinducss will at no time be throwu away.

FETCHING, CARRYING, SEEITNG, FINDING.

Nearly all dogs, (especially in their pup. pish days) have a natural propensity of running after objects and carrying them about. I have rarely met with an exception; it appears to be the instinctive pastime of the whole canine fraternity. There can be no difficulty therefore, in cultivating an instinct so amus. ing ; no barrier to directing it to pleasing and useful results. 'The first lesson must be perfect play. A ball, a piece of wood, or anything 
easy to grasp and not injurious to the teeth, shonld be thlown a little way. As soon as the pupil has picked it up, lic must be terpted, (if possible), to carry it back to his master. Should he not return to him with it, it should be gently taken out of lis mouth, and again thrown, ex. citing the dog a little between the acts. It should invariably be taken ont of his mouth. If he persist in holding it fast, tap lis nose, saying, "Let go Sir," to make him relax his holit; at the same time keep hold of the olyect, till he gives way. Then praise him and play with him a little. As he progresses, send the object farther and insist on his restoring it to you. Remember this: in training a dog, no more punishment must be administered, than iust enough to answer the purpose. Recollect also, that the less of reprimand you can get along with, the better. I have observed a general defect in all trained dogs; they are too "hard broken;" have been taught more to fear than to respect. See how snealingly they crouch at their master's thr at! This should not be. They should be engaged, as far as possible, to yield a willing obedience. A dog will show his style of education, as perceptiblv 
as a child, and the method pursued in his training is calculated either to secure to him a carcer of comfort and enjoyment, or to impreg. nate his erery morement, with a sneaking timidity, degrading to the brute and disreputable to his master. When he fetches well and is carrying the olject in his mouth, walk off, calling him to follow you. Do not go too far, before you take it from him; then gire it to him again and go a little farther. Shonld he drop it, make him pick it up again, which if he refuse, replace it in his mouth, and make him carry it again, and still go on, never omitting either to make him piek it up, or to replace it in his month yourself, erery time he may drop it. Aroil his dropping it at all, if you can, by not allowing him to carry it too far at first. When you are satisfied that he knows his duty, he may be corrected a little or scolded upon every transgression. A basket may now be given lim to carry, the handle of which must be phiced straight in his mouth. IIe must then follow with it. It should be taken from him at short intervals at first, (erery time praising nim up), gradually increasing the distance as before, and occasionally, should he drop it, lre 
may be made to feel his transcression. It all events, whenerer he drops it, lie must be impressed with a conscionsucss of wrong. The severity of the punishment must be praded according to the merciful judgment of the owner. Often a screre lucture will give great effect to a light chastisement. The basket should be thrown for him to fetch, and should he take hold of it wrong, the handle should be presented to him, that he may take it off the ground.

Secking and Fizcling, are also rery casy to teach a dog, already initiated in fetching and carrying. In order to effec: this, when you have thrown any thing, hold your pupil, a little, before you let him fetch it ; first of all a very short time and at a very short distance, increasing little by little both time and space. This being fairly accomplished, throw the object where he cannot see it. repeating the same means. Should he not find it immediately, pretend to help him look after it, eren pointing it out to him, if necessary. Make him follow you with it a little; then take it out of his mouth, drop it, unknown to him, and excite nim by "Look about" till he find jt. Continue this exerciss of dropping, until he is perfectly 
familiarized to it. After this, drop or place the object in any spot, holding him in view of it et the same time; then take him off a shor't dis. tance, but out of sight; whisper to him "Fetch $i t$ " and let him go, that he may bring it to you. You may reduce all your commands to a whisper, if the whisper be used conjointly with the regular word of command. In this manner, he is made clearly to understand, from having had a previous indication of your will. By dropping an article and causing him to fetch it, at graduated distances, he may be trained to retrieve at any length. In order to render this more effectual, introduce him occasionally to your pocket-book, gloves, handkerchief, cane, \&c. Of course he will the more readily reeognize these objects than other strange articles, and when dropped, he will never fail to recover them.

GOING ITTO AND FERCHING OUT OF THE WATER. DIVING.

Sone dogs hare such a desire for aquatic adventures, that they require only the sight or 


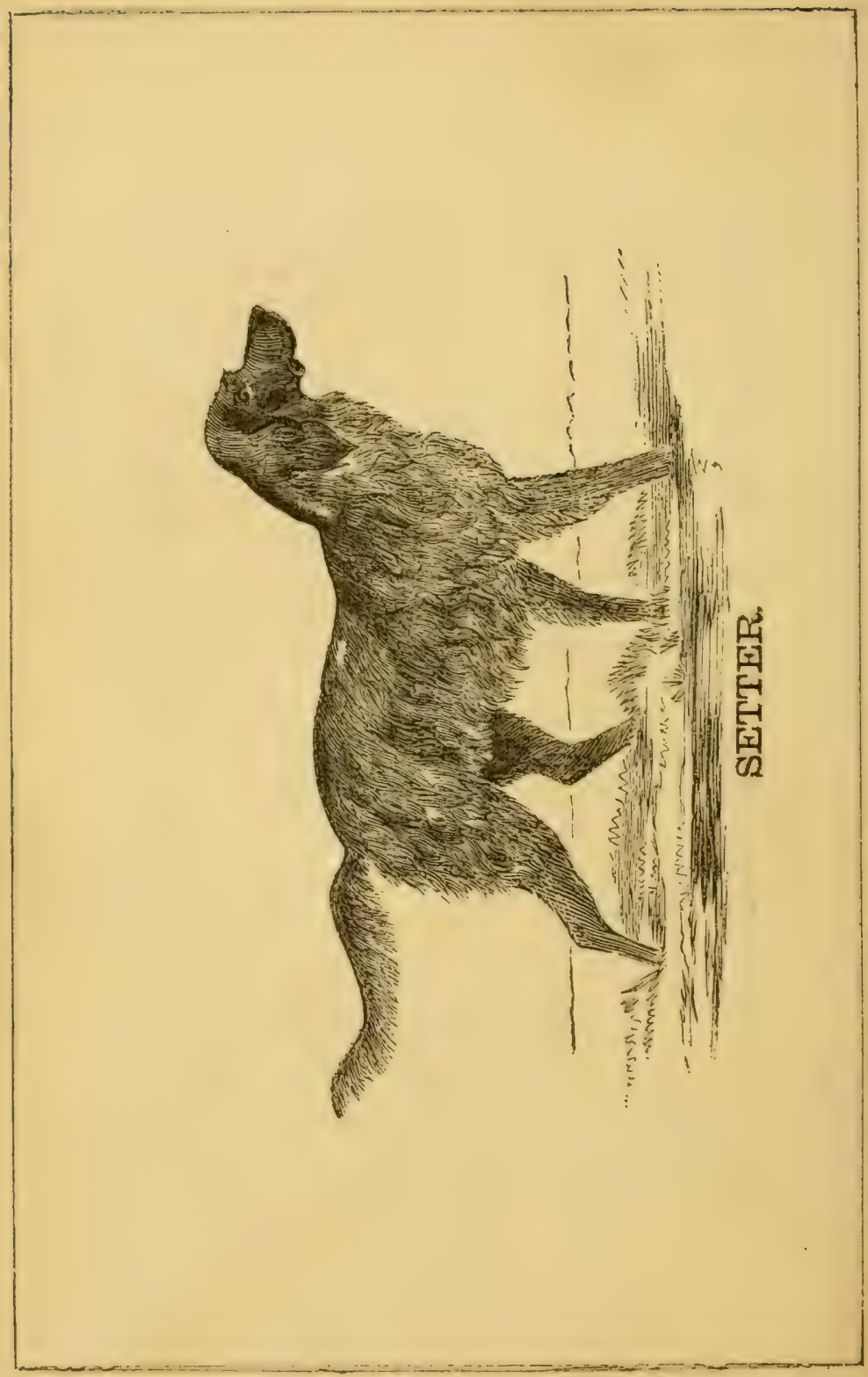




\section{SETTER.}

Red, brown, or orange, lirer, white or black: P'laps b'ack or tan. or mottled on the back;

little it matters, what his hue, ol sharle, If *nely cast, and well proportioned made. Such strange varieties smring up of late. Perdhance "t were vain, his salicut points to state;

Ear irooping low, with neatly feathered hair; Light flowing tail, and leygs well fringed with care ;

Bright serions eye, black nose, nor s'arp, nor round,

Unlike Itulian or King Charley hound;

Something in shape, in pattern and in monld, Like a Newfomuland, ahont six mont's old. 'Tho' nume but sinortsuen din'e his merits scan, 'T'is he, the choicest pastime gives to man; Ite finels the L'ore., Wootcoek. Suije and Rail; IIe points the Grouse, the l'heasunt, l'artridge, Quail ;

Like a trained Rifteman, he threads his way, But sulden laths, to mark his desined prey; With foot, well poised, and every nerre astrain, IIe holds his breath and stills his crery rein; With powcrful nerve, his strurerling wilidenies, Firm as a rock th' enchunted vietim eyes : 'I he fluttering game alone his bonds release, Or echo of the fatal. fowling piece. 
perhaps smell of the water, in moderate weather, to invite them in. The Newfoundland and Spaniel appear to have the strongest in. stinctive desire for swimming, though even some of these require considerable encourage. ment and training, to make them good waterdogs. I have however never raised a dog msyelf, whether Newfonmdland, St. Bernard, Spanicl, Terricr, \&c., withont laving casily imparted to him a particular fondness for the water. Greyhounds, thin-coated and hairless dogs are the most backward, on account of thicir light covering and chilly nature. I have known hardy Bull-terrices to face the ice, better than a Newfoundland, no doubt to be accounted for by their dauntless conrage and deternination, rather than by their fituess to resist the cold. A large dog is the more easily taught it, when young, than a pup of smaller breed, as he can renture farther, without getting out of lis depth. The first lesson should be in shallow water, or if deep, of rery gentle descent, as young dogs are often checked, on finding themselves too suddenly out of their depth. The pupil must be very gradually introduced to the watery element, by casting the object to be 
Petched, into shallow water, close to the bank. and taking it immediately out of his mouth on landing. 'The distance must be daily increased. according to the aptness of the scholar. Care should be taken to make the lessons very short, until lie is far enough adranced in practice, to venture freely of his own acenrd; even then it is injurious to prolong too much the cxercise, on account of disgusting the animal, or ('ausing him to be too much chilled or exhausted. A dog should upon no consideration be thrown into the water, unless you are positively satisfied he can never be tempted to venture alone. It will serve at any rate to purify his pelt, but will never make him a water-elog. Hundreds, who might have made good water-dogs, are ruined, by being foreed against their will, and thereby seared at the very iclea of d:inking out of a pond. When you begin your instructions, let it be in warm summor weather, that the dog may feel a real pleasure in cooling himself off. If you commence in cold weather, you may set your dog against it, by his disagreeable early impressions; therefore begin in shallow-water, and in warm weather, and let his introductory initiatious be short, easy and rery encouraging. 
He must be taught to dive on the same graduated principle. Let the object thrown, be a first barely under water, increasing its depth, according to progress. By way of practice, a tub may he used, and a piece of meat thrown into it, that he may be taught to immerse the whole head. In learning to fetch from the bottom of the water, the same article shouid be thrown, which he is perfectly willing to fetch on land, that he may be the more eager to talie it. In spite of all our endearors, entreaties, remonstrances and threats, some animals appear to be almost bomb jroof, against diving lessons; when such is the ease, their talents should be diverted in another chamel. Anything that sinks gradually in the water is the best to teach with, as on secing it sink, the animal will be the more likely to dip after it. A basket slightly weighted will answer this purpose. A duck will be found occasionally serviceable. One of his wings should be clipped a little, that he may be compelled to dire, in order to escape. But eren a duck will not always dive. Whilst a dorg is swimming, only one olject chould be allowed to engage his attention at once, which he should invariably be induecd to 
bring ashore. If he miss it, a stone should be thrown to point out the spot. But to assist in these swimming lessons, there is nothing like a well-trained water-dog; he will teach your beginner more swimming in ten minutes, than you can urge on him in a week. Dogs who in. dicate no aqueous desire whaterer, will often suddenly change their ideas, when another leads the way, eapecially if the latter be a com panion. When once thoroughly initiated, he is far better alone, as in fetching together, they nre apt to get in each other's way, and are likewise rather subject to quarrel. A lire rat to a rat dog or others is a great temptation. Any ocher animal demonstration may be devis. ed. should the canine prove unwilling from or dinary excitants.

GOING UP STAIRS, GOING DOWN STAIRS, KEEPIN( OUT OF DOORS, STAYING IN DOORS.

These are very simple things to teach, and as easily understood by the must ordinary of caume intelleøts. Here, the teacher's coaxing. 
is of little serrice. At first a person should be posted at the top of the stairs, whilst the mas ter stands at the bottom with his dog. The former must call whilst the latter seconds him by saying "Go up stairs Sir," and if necessa. ry should add the twig to his gentle rebules, in which case the student will be delighted to escape the blows, to rush to the protecrion of a friend. This repeated a few times, acompanied with the command "Up stairs," \&cc., wili soon be thoroughly understood, after which the word alone will be sufficient, and by practice even a whisper. If he be slow of eomprehension or backward in obedience, your friend at the top of the Stairs may tempt him with a light refreshment. The "Doun stairs Sir," may be eflected in the same way, simply by reversing the position of master and assistant. Recollect, practice makes perfect, and that good humor will ensure constant obedience, while severity and crabbedness are forbidding to the whole animal creation. Accustom your dog to signs, accompanying his every act of submission, and test him often by a whisper. Your distance from the stairs may be increased, according to progress. To keop a dog from entering a house, 
when the door is open. keep in some suitable bot, a long twig or whip; let it suddenly remind him, that he is decidedly out of place. Say nothing to him, till after the stripe is given, and then simply "Out." If the fimily agree to this method of treatment, a few simple cracks will not fail to keep him in his place; but, if in. vited in, loe will not fail to take advantage of the indulgence, in the absence of his monitors. The door should be occasionally left open, in order to test him, whilst a person is concealed close by. ready to adininister chastisement unawares. This will be effectual, as he will always besuspicious, when no one is at hand. He should also be tempted by a visitor, to walk in for a piece of meat, when he should be suddenly checked by an unseen hand, so that erentually no temptation will be of any avail, and the choicest viands will be secure from his attacks. In the city especially, it will be well to keep your dog from going out, when the street dloor is open. 'This may be effected by using the same means, in the street, that are recommended for the house. A stranger should tempt lim outside, whilst the master is in amhush to greet him with a twig and the word "In." The door 
may now and then be left open, whilst the dog is watehed and effectually taught that he must not go out, without his master, or a privileg'ed inmate of the house.

JUMPING THROUGH A HOOP; OVER A STICK, \&C. DOWN DEAD. STAND FIRE.

"Necessity is the mother of invention," particularly so, where the digestive organs are at stake. The safest and most expeditions method of teaching a dog how to jump through a hoop, is to hold a piece of meat, on the other side of it, denying him all other access to it, except ly going through. The hoop must be so lield or placed, that he ean neither get orer, under or round. At first he may be awkward, and blunder through it, but necessity and prac. tice will soon make him expert. As he progresses, the temptation may be withdrawn; still a stranger should not be allowed to practice him, without paying his fee.

When the dog has heen taught to lie down at command, lie must be made to remain 
stretched at full length and sererely threatened, if he offer to stir. He must then be pulled along by the tail and then by the leg, whilst you still insist on his perfect and motionless submission, which must absolutely be enforced at all hazards. This must be repented in short and casy doses, until he remains perfectly still. Al. though this lesson will require great firmness and decision, his temperature must be taken into scrious consideration, for, if you do not keep him in decent humor, you will render him the more intractable. If thercfore he be of the snappish caste, you should grade your exactiong accordingly. You may also test his dearlness by making him stand fire, while you strike all round him with a stick, call him by name, \&c., but he must only rise at the word " $U p$." You may then use any expression you think proper terminating with the word " $L p$," when of course he will briskly start up, regardless certainly of the words preceding it. For instance: you may say "If thieves were in the house, I don't beliere that dog would get " up." He will appear to understand it all, and spring up immediately. The word " $U p$ " should bo pronounced with emphasis enough to attract 


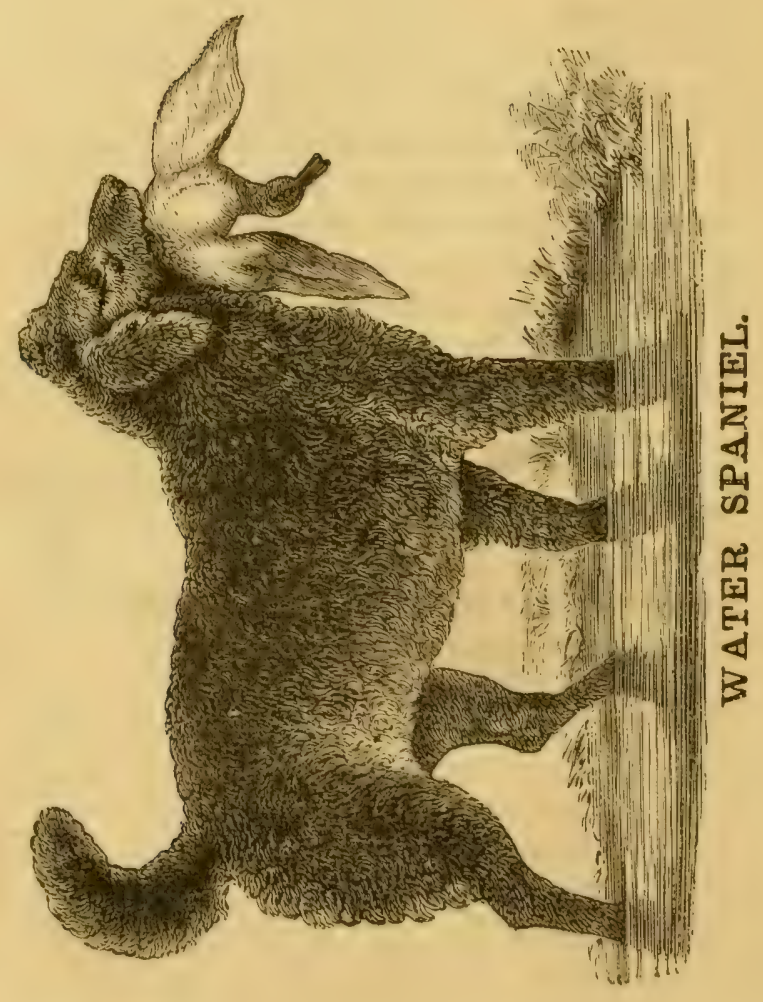




\section{WATER SPANIEL.}

Of him, the trifold merits we demand, Of Pointer, Beagle and of Newfoundland; Active, intelligent, determined, spry, In hunting qualities, with 11 ound may vie, With Pointer, trace the Woodcock, Snipe or Hare,

Or with Newfoundland, surging waters dare. In form compact, in temper faultless too, In pluck and vigilance excelled by few ; Best of retrievers, in all climates good, For river, swamp, or lirake, or thorny wood, Of liver color, oft'times mixed with white, The king of Spaniels, if but tutored right; Largest of all, in limb more firmly set, Fondest of all the Genus Canis yet;

Robust in frame, with soft and curling hair, Except the head, which should be somewhat bare ;

An eye full beaming with expression kind, Bespeaks his friendship and his trut! combined; An car, with graceful ringlets drooping low, His limbs well clad and feathered to the toe. Although Dogographers oft' disagree, Methinks his race original must be ; Oid England boasts the honor of his birth, His fame acknow'edged, and esteemed his worth, 
Lis attention, and still not to make it appear in . tentional. He must be practiced with "Up and Down" till he obeys instantly. All sorts of exciting words may be addressed to him, when dead, but the teacher must on no account allow him to stir, exeept to one command. An assistant will be useful to excite him in every way to rise, while his master insists on perfect "Dead." Be casy, firm and decided in your commands, and appear to be highly delighted in their execution, always allowing intervals for a frolic, between yourself and your pupil. You should never lose sight of this in your teachings. It is not so essential after the dog is thoronghly trained, but even then, it should be often resorted to, as an incentive to willing submission.

STEADY! WITH MEAT ON THE DOG'S NOSE. MEAT IN HIS MOUTH, NOT TO BE EATEN.

Place a piece of meat on the dog's nose; keep him steady with it there, till you have slowly counted "ten," repeating fuller the last 
number " $T e n$," after which, give him liberty to eat it. Repeat this manner, a few times; then make him keep perfectly still at the word "Sleudy," without touching him, after which the counting alone will soon be suffieient. It ho let it fall, before the ten is fully counted, he must be reprimanded or corrected and the operation resumed. During the lesson, he should have nothing given him, except after the word "Ten."

This being got through with, you may allow him to take a bit of meat or any thing nice in his mouth. At first, press his jaws gently, while you are counting; shonld he attempt to bite it, he must be checked and the pressure increased, repeating the word "Steady." Whien the ten is up, allow him to swallow it. Repeat this, after the same fashion, till you are satisfied he knows his duty; after you may gire him the hait in his mouth, trusting to his education alone. Again repeat, "Steady" and go on counting. Should he unfortunately swallow it, you must correct him according to your judgment, and commence another trial. As he becomes accustomed to his duty, you may count slower, and occasionally pause, to test his pa. 
tience. To try him more severely, exercise him when you know he is hungry. In any of your teachings, should you find it necessary, you may keep the dog within bounds. by a chain and collar, although it should be aroided, as far as possible. Nevertheless, it may occasionally be indispensable, to restrain the muruly or to embolden the timid. With animals, whose carly tuition has been neglected, it may be the morenecessary, as a more decisive treatment is requisite, and in many cases, we need the absolute power of correction, without admitting a chance of retaliation or escape.

FETCHING FROM THE STOLE. CARRYING TO A GIVEN POINT.

A Dos. $\pi$ ell rersed in ordinary fetching and carrying, will requile only a little directing and discretionary management, to enable him to execute many little useful errands to a neigh. boring store, or eren at a considerable distance. It would not be adrabable 10 practice it much 
n the City, unless the animal is watched, as the poor creature runs a great risk of abuse, with out any chance of redress, and such an exposure might prove injurious both to his phrsical and mental developments, by deterring him from similiar adrentures for the futurc, to say nothing of the risk of his coming in contact with a new master. The same means recom. mended for "Going up and doun stairs" must be resorted to here. When he is taught to fetch the basket, it may be left in a Store or elsewhere, whence he should be made to fetch it ont; (Sce "Fetching") first only at a short distance, and in sight. When this is done, a person in the store, should call the dog, who holds the basket in hismouth, while standing by his master, who orders him to go to the store, the person in the store should take the basket out of his mouth, and replace it shortly after, adding the word "Back" and giving him sigus to return to his master, who should call him at the same time. After a few revetitions of Backuards and Foriards, aided by the second person, the owner may begin by sending him alone, not forgetting to finish with the word "Store," at every command. He should 


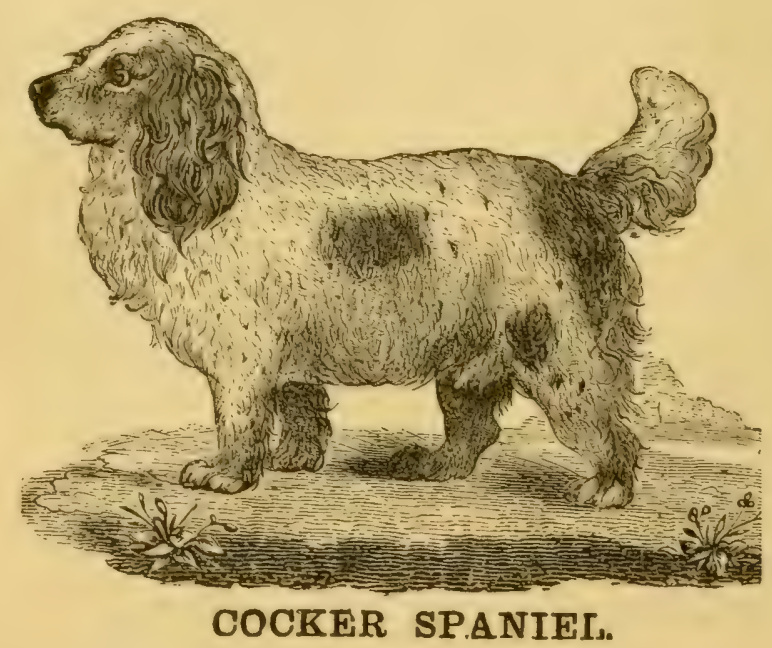




\section{COCKER SPANIEL.}

In size fifteen, to thirty pounds hetwist; Of liver color, or with white commixed; Lively and gay, intelligent and spry ; Ears pendant, flowing hair, endearing eve : For Snipe or Woodcock, Rail, and such like grame,

Well known his worth, indelible his fame ;

Where Pointer, Setter cease their game to trace, He rushes to their covert hiding place.

Like the Feoteh terrier, threads his sinnous way, Nor tangied briars, his onward movement stay; Ever afield and ever in again,

Careful he scours the wood and scans the plain. Returning oft', to seek his master's will; Anxions his joyous mission to fulfil.

Look where you may, among the canine inass, In seenting powers, the Cocker none surpass: In learning apt, and fawning in his ways; 'l'rue in affection, sensilive to praise; Excels in memory, passing foul of fire, While yet for water, native, his desire. If e'er to man, decreed a friend above, His looks are fondness, and his actions love ; No treatment harsh, or cruel, or unjust, Can e'er seduce him from his wonted trust. 
invariabiy be encourager by both partics and occasionally have a penny to spend for himself. When he goes entirely on his own account. another and a different kind of basket should le used, so that he may be taught to distinguish between his own private affiairs and the business of his master. A penny may be wrapped up, which he may be sent to lay out for himself, which of course, should be spent for something eatable. If he were tanght this iurariably at regular hours, he would as certainly come at the appointed time for his penny, as for his reg. ular meals. By this simple way of training, a dog may be rendered higlly serviceable, in the country; he can fetch the milk from a neighboring farm, supply the kitchen with wood, do all the little errands at the store, and make him. self generally useful. Nuch time need not be devoted to educate an animal thoroughly ; constant habit and experience will work wonders on him. Only feed a dog three days in succes. sion, at the sume hour, if you omit the fourth, you may be sure he will remind you of it. Colrect him three times for the same transgression, and he will searecly ever require another reprimand. His momory surpasses in many things, that of 
the human race, and he is alike the creature of habit and circumstance. Let your lessons be short and regular; make them as pleasing and cxciting as you can, and your pupil will always be up and ready, cheerful and willing to execute either your nod or your whisper. Is it not worth while to rise a quarter of an hour carlice (if necessary) for a fow months, to educate a faithful friend, who will be rendered the happier, by deroting his whole life to your useful service.

TEACH YOUR DOG TO CALL YOU, AT A REGULAR HoUR.

ArthoUgir the Dog may be considered disin. terested in his affection and fidelity to his owner, he is neverticless as really alive to his own interests, as is the master, whom he serves. INe has the same animal wants, is born with the same natural desires and necessities, which are absolutely essential to his support and pro. tection. Self-interest is the most important and the absolutely indispeusable ground-work 
of all the acquirements of the master anil his dog. The dog must be made to enjoy the dis. play of his talents, by hopes of encouragement or reward, else lie will be slow to obey and difficult to instruct.

If you wish your favorite to arouse you at nny particular hour of the morning, the hour should be definitely fixed on. If he be fed at that time only, it will greatly facilitate his memory and absolutely cusure his punctual attendance. The master should regularly call his dorg to the door of his sleeping apartment, at the time required, and give him some very palatable refreshment; after which he should be gently ordered away. This treatment should be continued, until the student be eonstantly found at his post without being called. On the master's calling, the bed-room door should be left open for several times, so that the animal may clearly understand where he is to go ; after which it may be closed and his visit awaited inside. Should he fail to attend at the usual hour, he should be called and the door closed, so that he may knock or scratch for admission. This of course must be repeated according to the aptness of the pupil. 
If, after this lie should be at his post, and make no importunate efforts at the door, he should be called from the inside, which will excite him to attempt a forcible entry. By repeating this a few times, if you fail to call him, he will get impatient and knock at the door. Be very careful to be mild in your commands, when you order him down stairs, or he might other. wise be led to conclude that he was forbidden to come up. Give him his fee, pat, flatter and gently dismiss lim. If you please, you may cause him to lic on a mat, outside your chamber till you are ready to go down, when you should take him out of doors and exereise him in a little frolic, \&c. This would bean extra inducement to his regular attendance.

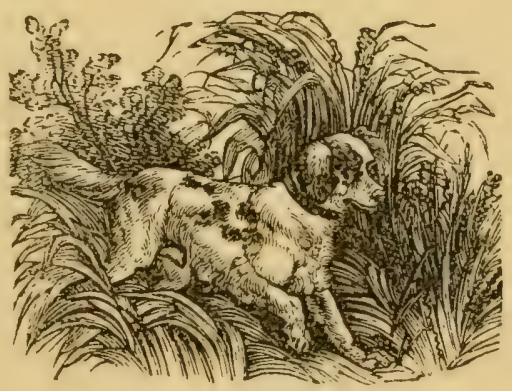




\section{TO MAKE TRUSTY IVATCH DOGS AND GOOD RATTERS.}

BAREING is the peculiar prerogative of nog. dom. By many, an animal that makes an incessant yelping, disturbing his master and annoying his neighbors, is considered a first rate watch dog. This is certainly a false criterion : a bascless conclusion. An animal that is really good, will not be annoyed by the distant yelling of ill-bred mongrels, neither will he be excited by every form that crosses within his gaze, nor will he exercise his roice unless he have some cause of suspecting a trespass on his domain.

When a dog barks without sufficient cause, he should invariably be checked. Should he persist in making unnecessary noises of any kind, you should wait concealed, somewlicre near him, so as to catch him in the act, and 
purish him accordingly, to the tune of " $I n$, Sir." A few light and timely corrections will suffice to silence him, and impose on him a sal. "tary dread of your presence, and should he occs. sionally forget limself, a simple "In Sir" will take a wonderful effect on him. On the other hand, he should le excited to vigilance in the right direction, and should be praised in all lawful efforte to ward off the attacks of the in. rader. He should hare the extent of his range clearly pointed out to him, and be also discour. aged in any attempt to pass the boundaries of his stewardship. It is well to walk round the premises with him occasionally, and excite him at anything nearing his bounds, at the same time, peremptorily checking him, should he attempt to cross the barrier. He should not be allowed many acquaintances, neither should he be permitted to follow any bat his master. A stranger may be employed to strike against the fence, or anmoy him at his kennel. Should he appear listless, he should be urged to the attack. A bullock's or hor'se's head, or a large bone of meat may be given him, when he is chained, and should it fail to render him 
134 WATCH-DOGS, RATTERS, \&C.

watchful, a stranger should poke it occasionaily with a long pole. He should not however he allowed to gnaw his bone too near, when hungry. A hard bone is rery rearing to the teeth of a hungry animal ; but I consider it ${ }^{-}$a benefit to a certain extent, if the animal he not too hard set with hunger, to injure his teeth.

If you wish him to scize every stranger he sees, you should make the effigy of a man and encourage him to fly at and tear it, and whilst you hold on to his chain, set him at any individuals who may be willing to second your efforts in making him a "regular graliber." If he have any original grit, you may temper his disposition to any grade of severity : citler re. dueing it to a lower standard, by introducing him to society, accustoming him to strangers, kecping him always unchained, checking him in his barks, snaps and growls, feerling him on a farinaccous or vegetable diet, allowing him to accompany a variety of persons, placing lim in a situation where there is a great deal of passing; in fine, you may, by constant checks and tyrannous severity subdue his hycna-temperament, till he becomes scared at the rustling of a leaf, or the creak of a shutter. It must 
then be left to your own judgment, to mould him to your will, to direct, moderate or excite his instinctire and reasoning derelopements. In the selection of a full grown guard-dog, whose character is already former, of course, you must be somewhat governed by the position and extent of the premises, to be committer to his charge, and the nature of the services to he required of him. If you prefer raising one from a puppy, I should recommend a Newfoundland, St. Bernard, or a cross between the two. as calculated to make the best family-dogrs, which from being generally admired by er. ery one and less liable to ill-usage, are noble and frank in their deportment, free from treach. ery, less ferocions, yet more powerful and impo. sing than canines of minor growth.

They are in the habit of holding without tearing, watching without yelping, and with a slight knowledge of the world, readily distin. guishing the man of business from the sneaking beggar, welcoming legitimate visitorsyet deny. ing admission to suspicious invaders.

In spite of all risk and trouble, I decidenly prefer raising my own dog, as I then know exartly what he is. Should he not equal $\mathrm{my}$ 


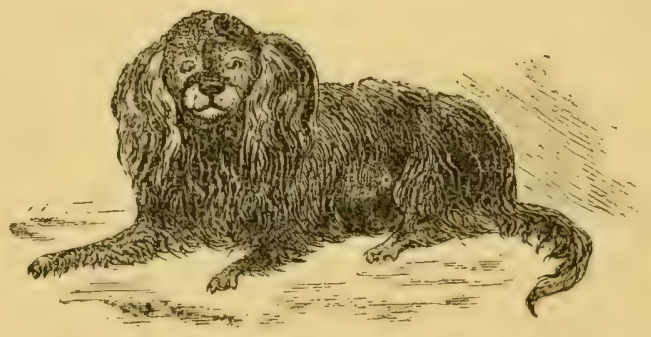

\section{KING CHARI,ES SPANIET.}




\section{KING CHARLES' DOG.}

A perfect specimen of Charley hound:

Of all canines the rarest to be found.

His points are eight, yet, if in ought he lack, Like a base counterfeit, we send him back.

Head, eye and ear, nose, coat, shape, co!lor, size: In these combined, the stainp of lieanty lies.

Head, full and round, large cye, projecting clear, With short snub nose, and long well feathered ear ;

Ten pounds, or less may be allowed to weigh ; The sinaller, the more valuable they say.

Well shaped his form, nor should a hair of white,

A doubt of his royal pedigree invite;

of glossy coat, with raven locks beset,

Face, breast and limb of tan, and body jet.

To Second Charles of England, owes his name,

A regal gift from Second Charles of Spain.

Although, since then two hundred years hare flown.

Still fashion's favnrite, as when first was known, He wears liis honors, with becoming pride, Jealous with ought his tribute to divide. Flattered by all, the menial and the great, On him the Page and powdered Flunkey wait ; On velvet couch, with Royalty reclines, And with the queen, and heir presumptive dines. 
anticipations, I should attribute it to my own neglect, provided he were the offspring of undoubtedly good stock. There may be excen. tions, though it has not hitherto been my misfor. tune to encounter one.

For a good Rat-dog, select either a Scotch or an English Terrier. Scotch is the hardiest and stands the most work. When he is young, give him something he can kill, wilhout being much punished, a small rat on a string, or a muuse. Put him often at a rat bole to scrateh. If you can, let him be with an old killer, that he may see the performance. Excite him well, before you let him have the rat. Don't let him pound him much after he is dead, don't hunt him on a full stomach to disgust him with the taste of the rat, nor allow him to kill many at trst.

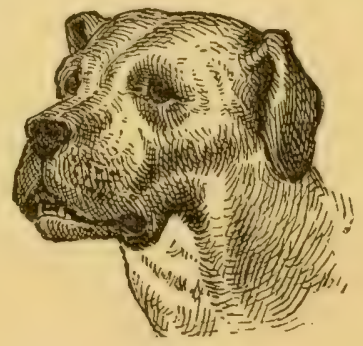




\section{ON THE TRAINING OF FIGHTING DOGS.}

As I am particularly requested to compound a chapter on the training of fighting-dogs, for the satisfaction of the curions, I will endearor to present a few general ideas on the sulject, for some of which, I heg to acknowledge my indebteduess to a learned professor of the art. The sulject is grating to the ear of most penple of refinement, by whom the practice of Dog-fighting is justly condemned as neither resprectalile nor moral. Simply testing the courage and endurance of particular breeds of animals, (whose valor we are anxious to prove, in order to satisfy ourselres of the intrinsic merits of the stock as guardians, hunters, \&c.), may perhaps be pardonable, to a certain extent, as these virtnes are important ingredients in the component parts of a trustworthy companion 
a sd defender; but that an animal, whose pluck has been thoroughly verified, should be teased, torn and tortured, solely to satisfy the deprared taste of the thoughtless and desperate. few would dare to assert. However strange it may appear, the owner of a fighting dog is perhaps as careful and teider over him, as the lady with her parlor-pet. The s'ightest insult offered to his dog would be a personal challenge te limself, and although the animal may be devoted by his guardian to battle and death, the poor confiding brute is greedy of the honor of perishing in defence of him, who sacrifices his only disinterested friend, to reap the benefit of his sufferings and the glory of his scars.

These dogs (Bulls and Bull-terriers) are decidedly the most courageous, but not naturally more quarrelsome than others; but no sooner can they run, than their latent passions are cxcited and thoir courage put to the test; they are perhaps sccluded from respectable associates at the end of a four foot-chain, there to be ageravated, poked and worricd by their owners and others, through wlose instrumentality they are defamed, dreader and despised. A dog, to be in good fettle and condition for 
fighting, must not be allowed to carry more flesh than is necessary for his health, and that should be firm and solid. When he is matched to fight at a certain weight or under, he has generally to be reduced or increased in weight ; more commonly the former. In either case, at the commencement of his training, the animal should be (what is technically termed), purged out. His stomach must be first cleansed by abont two grains of Tartar emetic. On the following day, he should have small doses of castor-oil or other opening medicine, every two or three hours, until his bowels are thoroughly purified. When this is effected, the renovation, by care, regular bracing excrcise and diet, begins. The food sliould be of the most nonrishing kind, yet great care must be taken not to orerload the stomach. He must be fed lightly three times a day, so that he may be enabled to stand the repeated and arduous exereises to which he must be subjected, as his endurance has to be tested by as much hard work, as he can bear. (rood beef, broiled ard rery little blood left in it, should be his diet, with hard biscuit occasionally, or his diet may be varied if occasion require. No blood. raw 
meat, liver or vegetables may be given him. The quantity given him must depend on his appetite, his condition, and the amount of flesh to be worked off by exercise. He should be allowed very little water; at the same time; ferer from thirst should be carefully guarded against; therefore he may have little and often, that he may require the less. He should be kept in a sufficiently warm temperature, and not exposed to either cold or heat. Should he be taken out in the cold air, his loins slould be corered, and he must be kept moving at a brisk pace. He had better not be exercised out of doors, either in hot or cold weather, excepting carly in the morning in summer. As to the ways in which he may be exercised, they are varions: the harder the work in reason, the better. A stuffed bag may be suspended from the cicling, and when the dog is muzled, he should be excited to seize it. A large ball may be rolled for him to rum after, or he may run a few miles oceasionally at a brisk pace, following a horse. 'These exercises must be persisted in as far as he can conveniently bear, which must be left to the judgment of his trainer, but the animal should nevor be allowed to exhaust himself too much 
at once, or to suffer for want of food or water. If his bowels should become too constipated, a little magnesia may be given him, perhaps an injection of soap suds, or his cxercise may be increased. If he should be in anywise relaxed, his becf should be more cooked, his bisenit more baked and his exereise diminished for a season. However no powerful purgatire should be given, unless in case of an absolute stoppage. While it is highly important that he should not he overfed, he must not be reduced below his strength. As a safeguard against a mis. take of this kind, he should be weighed every morning lefore feeding. His best figliting and most healthy weight should be ascertained, as it is safer to grive nne's adrersary the adrant. agre of a pound or two than to reduce one's dog below his real fighting standard. The less your dog has been accustomed to excrcise, the more time should you demand previous to his bighting; as courage without endurance is a common defect in dogs, who have not becn thor. oughly hrrelened to toil ; and many a plucky animal has turued for want of breath, when he bad courage enough to face a hundred deaths. In hasty matches, dogs are often rapidly sweat. 


\section{TIAINING OF FIGHTING-DOGS.}

ed down, which is very disadvantageous to them and ought to be avoided. The amount of food ought not to be much shortened too suddenly. but a little more or less every meal. After hard exercise the animal should be well suhbed and well sovered.

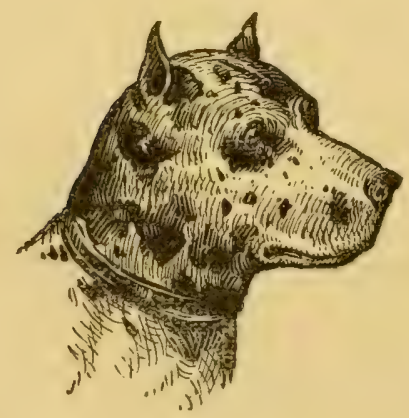


COMPARATIVE VIRTUES OE POINTE? AND SE'I'IER.

Mucr has been said with regard to the respective merits of Pointer and Setter. Some Sportsmen stoutly mantain that the Pointer is far the superior, whilst others aver that the Setter is greatly to be preferred. Each however, has his distinctive merits. He, who has been the owner of a few good Pointers, and has chanced to be the proprietor of a bad Setter or two, is inclined to believe that the Setter must be the inferior, and vice versa.

This is a wholesale mistake, yet lyy no means a common yet unfair inference. 'The Setter is hardier, stands his work better in cold weather. is generally superior as a water-dog, bolder in thick corer and less suspectible to injury by thorns, \&c. The Pointer stands the heat hets 


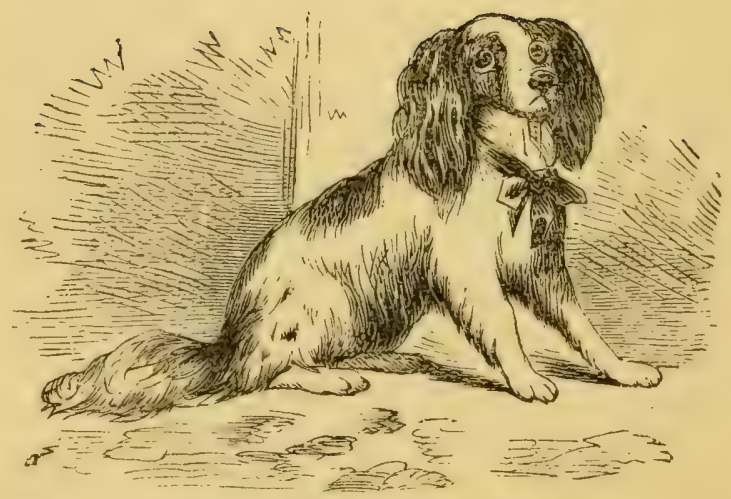

BLENHEIM SPANIEL. 


\section{BLENHELM SPANIEL.}

of Charsey stock, in shape and feature par, If nought contend his regal stamp to mar; Orange and white, the genuine it is said, Or black and white, with features tinged with red.

Descended from an ancient Spanish race, In vain, his prime original we trace; Once a famed hunter, of Castilian state, 'I'ho' since enfeebled and effeminate; So elegant, so highly bred and so gentecl, These honored traits his pedigree reveal; His virtuous failings, that once vice were deemed,

His passive dignity, now must estecmed.

If ought of preference 'twixt the two be found, Yield it in favor of the Charley hound; The latter fuller tasselled, more compact, With larger eye and feature more exact. I've oft' remarked, with beasts of every grade, Hardier and healthier is the darker shade ; This in a measure may perchance explain, Why Charley more of vigor may retain. As Charley's virtues are of Blenheim true, It bodes me not his morits to review ; If further scrutiny, your thoughts engage, Please turn to Charley, on the othor page. 


\section{VIRTUES OF PUINTER AND SETTER.}

ter, can trarel farther without, water, is consid. ered less difficult to break and less headstrong in the field. The one suffers more from the cold, the other from the heat. $\Lambda$ Setter appears to formet his training more easily than a Jointer; the only way in which I can acconnt for it, is the mixture of Spaniel to which I believe the former is partly indehted for his origin. If either can boast of originality of race, I should certainly, (contrary to the general opinion) attribute it to the P'ointer, who shows no trace of syaniel, and canot have inberifed his bird-hmuting and stutionery instinet from the Foxhound, fiom whom he is said hy Natural. ists to have drseculded. 'Jo the Setter appears to belong th: stubhorn willness of the Spanicl. 'The Pointer if not delicately reared o: too finely bred, will stand on the arerage as much work as the Setter.

'I'he color of a hunting dog is of sone little importance. Dark colors absorb the rays of the sum much more than light ones, and are consequently less adapted for hot climates. In hot weather, the Pointer may be said to be preferable to the Setter on account of the lightuess of his dress, although the sun itself 
VIRTUES OF POINTER AND SETTER. 149

would take more effect on the thin-coated Poin ter, than on the thicker covering of the Setter whereas the air, which would keep a P'ointer cool, would scarcely be felt through the heary dress of the Setter.

Before we decide then, which is to be preferred, the Pointer or Setter; let us take into consideration Breed, Habits, Climate. IVeather, Country, \&e., and stake our opinions accord. ingly.

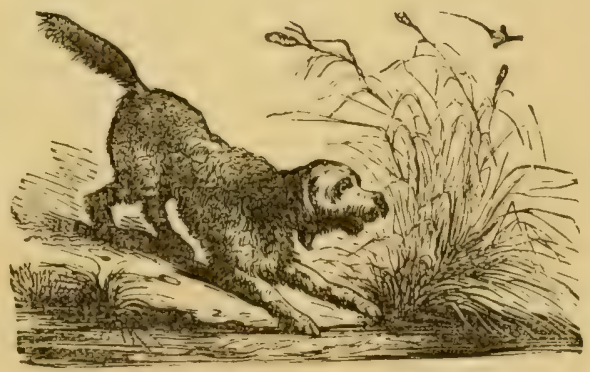




\section{TRAINING AND BREAKING POINTERS AND SET'IERS.}

I Ax not aware that there is anything mysterious in the art of training a Sporting-Dog; although it might be inferred from the scarcity of thoroughly broken animals, either that it were a secret, revealed only to a few professional Breakers, or that few ever made the attempt, either from lack of time, talent or sclf confidence. This may be sufficient to form a plausible reason for neglecting the education of the Sporting-Dog; though, after all, to come when he is called, and to do as he is bid, is about all that the most scrupulous could exact from him ; the balance must be left to develop itself in his own native instinet and sagacity. It necessarily follows that an early education is of the lighest importance. It is then that 
his habits are formed, his powers developed and his submission secured. Should he not b introduced to his fielding or training, till he has nearly reached his growth, he can be brolien. it is true, but with far greater difficulty, and at the risk of annihilating the noblest qualities of his nature. He will be always more or less difficult of restraint and will require pretty constant exercise to remind him of his duty ; whereas, with an carly and judicious course of moderate instruction and implicit oberlience, he is well brought up, and when more finly developed, requires but a slight introciuction into any new field of labor, to arouse his already well organized intellect.

Breaking is certainly a very appropriate term for pounding bad habits out of canine pelts; habits, which never could hare been contracted, lad ordinary attention been paid to early tuition. When animals commence their training after months of entire freedom from restraint, severity is often necessary, as they become so naturally self-willed, as abso. lutely to require Breaking. It is the easiest thing in the world to prevent a bad habit, but often next to an impossibility to restrain it. 
It is a common old Proverb "It's hard to teach an old dog. new tricks." but. hard indeed as it is, it has continually to be done, yet is often done so imperfectly, and I may add so improperly, that a well-trained dng is au exception, to the army of half-broken ones; so that sportsmen are continually in trouble, for want of a first-rate dog. One is too wild; another isn't staunch; a third won't fetch his game; the fourth isn't under good command: the fifth pounds his bird; the sixth won't take the water ; the seventh bolts at the first scolding; the eighth is apt to take after rabbits and squirrels; the ninth won't point the dead hird; the tenth is often inclined to disobedience or may follow another Sportsman, who may offer him a bait. I could enlarge on the defects of many nomincilly brotien dogs, but fear I may be accused of doing so already. I enumerate these vices, simply to repeat, that were they early taught and brought up to habits of implicit oberlience, these failings would seldom or never ocemr.

In the first place, if you wish to raise a Sporting Dog, set two; so that if one shonld dic, you may still have one loft. If one bo 
THAINING POINTERE AND SETTERS. 153

better than throther. keep the best; if they bo both good, one will pay the other's delsts, if you feel inclined to dispose of him; though I deciderly recommend you to keep them both. See that they are the offspring of rood and. healthful stock. If you have the choice of a [m], sclect the strongest, the holdest, the hand. somest of the litter. Tothing like a little fre to work upon. "The wildest colt generally makes the best horsc." As to color, it is mere fancy, and in my opinion amounts to nothing, cxcept in as far as climate is concerned, or the color of the ground you may be called to shoot over. I lo not imagine for a moment that the dog himself is the better for heing either white, black, orange or liver, but a light color is cer. tainly preferable in a hot climate, as the sun has less effeet on it. I refer you to several of the preceding " Dng Tricks," which will assist you in training a Fporting Dog, as well as any other breed, such as: "Down, seek and find, felch and carry, going in the water, going on, keeping in, \&.c."

This is all very well, but a Sporting Dog, requires somewhat more than this; he must be trained to hunt. must be practiced in funding 
154 TRIINING POINTERS AND SETTERS.

his game, quartering his ground, \&c., he will require continual restraint and must be kept within reasonable distance of his master. If ho only be well bred, he will need but little excitement to attend to his work. His natural instincts will only require directing or restrain. ing to suit his master's will. His habits of implicit obedience may be formed either in or sut of the field, but he should be brought to practice as early as possible in the theatre of his glory.

There are only two points to be attended to in Dog-training, these are: first, what the animal shall be compelled not to do, and secondly, what he shall be taught and induced to do. The first point is far more easily orercome than the second, and simply consists in decided checks on all his attempts, either to enforee his own will or to act in defiance of that of his master. The second requires somewhat more of knowledge, judgment, insight, patience and discretion than the first. It consists in moderating and directing his natural porrers, engaging them to be subservient to your will, and in moulding them to act well the part they are destined to perform. 
TRANING POINTERS AND SETTERS. 157

Let us suppose him then, perfectly up to the mark of Down charge! Come in! Keep in! IIie on! Seck and find, fetch, carry, go in the water! (according to previous lessons), or at auy rate perfectly obedient, as far as he has been taught. We will now teach him, or rather let him show us how to find the game, de. By way of trial, suppose we get a live quail or partridge, clip its wing, attach a string to its leg and let it run a hundred yards or so in diflerent directions; to test his nose, (a dead bird may be dragged along, if a live one cansot be obtained). Sclect a good sized field, drag it, or let it run in four different directions, set the dog on the scent, so that if he go wrong, you may direct and encourage him to hunt in the right direction. When you finish dragging, put the bird in a box and test the actions of your dog, making him. Steady, \&c., as he approaches it. Where gatme is abundant, of course this sham hunt need not of ten be resorted to, although a few minutes may occasionally be found for practice at home, when there is no spare time even for a short shooting-trip. "Down charge" may be taught to be obeyed by the discharge of the gun, if the report be often made to accomprany 


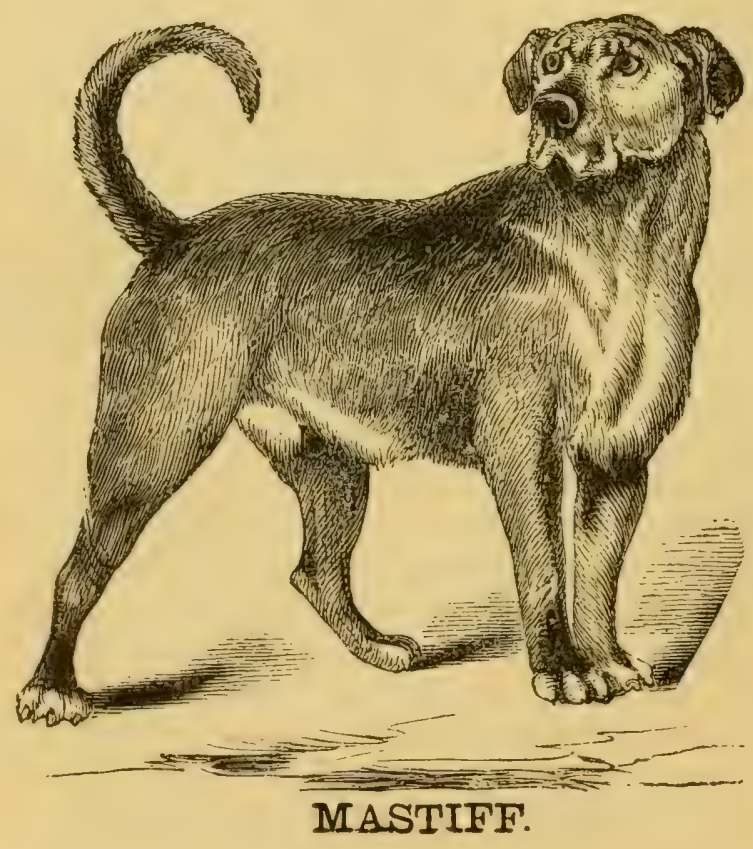




\section{MASTIFF.}

3erious and stern, majestic, brave and bold, The Baron's pride, in Halcyon days of old, Escuteheoned uft, by kniglits and men of state The dreaded guardian of the castle grate. His head, somewhat the contour of the Bull, With pendunt ear, deep chest, both broad and full :

In color red. or tawny, by the by,

Deep hanging jowl, black lip, and threatening cye :

His coat clwesct, s. zioritcr doubly strong, From tip to tip, he may be six feet long.

By massire walls and ponderous bar's confined Alone, he reigns, contented and resigned; Heedless of danger, marks no distant sound, Solemu and poncive, stalks his dreary round: The thief"s detector", and the foeman's dread, Silent and listful, notes each stealthy tread; Honest, ingenuous, true in all his ways, Emblem of salety, in the bygone days. Let not degencrate stock his name disgrace, Nor soil the virtues of this noble race ; Dauntless of yore, and just as sturdy now, He bears the stamp of England on his brow; Earnest in friendship, and of candor full, Distant to strang: ys, like a true John Bull. 
the command, but many have a great olyection to it, as the dog may be often checked in his duty, by the discharge of another fou ling piece. This may be left however, to the option of the owner. Quartering the ground is not difficult to teach, lut requires considerable good hmor and encouragement, accompanied hy "Hic on" and the ware of the hand in the requred direction. Should he take the wrong beat, he should at first be recalled and redirected, and thus continually exercised in following the voice, acenmpanied by the wave of the hand, so that he may be erentually commanied and directed by the hand alone. Various methods are arlopted by Breakirs to teach clogs to oliey their commands. I have seen many a pool animat with his neck in wounds by the use of the force collar, (a strap lined inside with spikes, or a string of spiked balls) to punish the poor beast, upon erery light deviation from his master's command. A long string is attached to the collar. and the check is given when any order is not immediately executed This method, I certainly do not admire, althongh there are cases (where animals have bcen entirely neglected in early life), which 
TRAINING POINTERS AND SETHERS. 161

may aboislutcly warrant it, when all milder at tempts have proved fruitless.

Another methorl is adopted to prevent a dog from pounding his game. He is taught to fetch and carry that only, which will hurt his month, if he press hardly on it. But the difficulty in teaching a dog to fetch is greatly increased, when lie is continually suspicious of in. juring himself; therefore if this method be adopted, great eare must be taken that the article used for feteling jurposes be so fixed, as in no way to injure his mouth except mpon hard pressure. A better and safer method however, I believe to be, to accustom him to carry a partridge or quail, teaching him by snitable instruction, reprimand and correction, that he must neitler mumble, maim, nor mutilate it. He will not be found to fetch as checrfully, of his own free will, if his gums have suffered by the trial. Nevertheless the spiking system, if carefully carried out and without sererity may oceasionally be advisable in perverse subjects, when the disposition to pound appears difficult to eradicate.

'The principal error committed in training Sporting-dogs, is in the use of severe and threat. 


\section{TRAINING POINTEIRS AND SETTERS.}

ening language not unfrequently accompanied hy the lash, to induce the animals to perform an act, which they camot thoroughly comprehend. Now, when a dog is caught in an act of positive transgression, punishment may serve to convince him of the wrong committed; but on the other hand, an act of non-committal is not so easily defined, and the correction may often be interpreted by the sufferer, as a caution against its performance. Therefore encouragement, rather than threats should be the basis of all our attempts to direct the instinctive developments of the sporting dog; our rebules and punishments should be reserved for enforcing submission, and of testifying our disapproval of conscious disobedience. Every thing should be done to ensure both respect and affec. tion, and sererity will seldom be called for. Recipes for training $\operatorname{lng}_{\mathrm{g}}$ will be of little service, unless their owners have common sense enough to compreliend somewhat of the raried dispositions of canine nature. Some animals need to be dealt very gently with, whilst others are almost insensible to moderate treatment, jet firmuess without severity, determination softened by patience, must be our sgencral rule 


\section{TRAINING PUINTERS AND SETTERS. 163}

The exceptions must be managed, according to the judgment of the trainer.

The amount of reprimand and correction reyuired in such hard eases should howerer be dealt out in graduated doses, so that, at all events enough may suffice. The Sporting-dog, especially should have a few minutes run erery day, not only for the benefit of his health, but to prevent his wildness in the field. Dogs, after being tied up for a length of time, become so elated, when set at liberty, that they are not only excessively wild and of ten unruly, but un. fitted for a day's work and apt to wear themselves out in a hurry; whereas a dog, regularly exercised, is seldom known to tire, is always in good condition, easily kept under good command and rarely troubled with sore feet. Many sportsmen are in the habit of letting fly a charge of dust-shot at their dogs, when they undertake to run after the game, or when they refuse to obey call. In France, especially, I have seen many peppered sterns. It may have a good effect sometimes, (if our animals coald only get used to it) but I consider it a very dangerous practice, as I have known several dogs utterly ruined hy it. 


\section{TRAINING PONNELS AND SETTERS.}

An old and well-trained dog is very advanta. geons in assisting in the field-training of the youmg beginuer; though the latter should be previously well rersed in all necessary acts of obsdience and suhuision, or it will generally render him the wilder and interfere with the tactics of the more experienced. If the young dog you are training, give evident proofs of a lack of nose, or game-scenting powers, you had better dispose of him at once, as this is a defect, for which no virtue can ever atone. It is well to carry a few crackers in your game-liag and give your dog a bite now and then, to enliven his spirits and increase his endurance. Give him but little meat, during the working seaton, unless it be well boiled and mixed with Indian meal, oat meal or eracker, \&c., whichercr be most conrenient or suit him hest ; but, if gon ean get nothing but meat, don't kecp him too short, on that account, as his strength must be kept up. $\Lambda$ good rubling, a good supper, and a wallm bed will do him good after a hard day's work. 


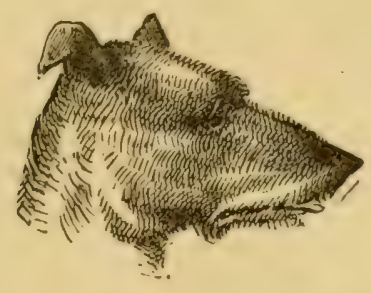

\section{GFNEIIT, REMIARKS ON TIE DIS EASES OF DOGS.}

It may perhaps somewhat surprise those who have hitherto been accustomed to a variety of incomprehensible Latin Prescriptions, receipterl to curc Diseases which are not positirely known to exist, or which are so mystified by anatomical techuiculities, that they cammot be easily recornized by the minitiated. Y ea: I doubt not some of my rearlers may be astonisied, (on reading my simple remarks and prartical instructions on the Diseases of Dogs.) that I have neitler unvailed the secret of the Apothecaries' shop, nor dissecterl every fibre of the canine fabric. 'These things, I have 


\section{IEILARKS OF DISEASES OF DOGS.}

carefully avoided, first, because 1 am by profession neither Chemist nor Anatomist ; second$\mathrm{ly}$, because my object is to simplify that which is too often rendered unintelligible, and to present a condensed lisi of antidotes, rather than a profusion of infallible cures. I perfectly agree with my learned friend Deschampss, who acknowlerges the existence of only one Disease, "a Disorganization of Nature," and one cure, "the Reorganization" I will proceed still further by stating my belich that Nature effects through suitable relaxation and gentle stim. ulants far more than can be forced on $\mathrm{Her}$ by drastic purges or powerful astringents. Preventives generally indicate cures; upon this impression I have based my ideas and am satisfied in having carried them out in my treatment of the Diseases of Dogs. If I err, I an convineed it is on the safe side. I have nothing to say in contradiction to the opinions of others, but as that which I offer is the result of my own experience, I have reason tr hope it may be tested, before it is condemned. As, in a errtain sense, all Diseases are one, I have not particularized every ailment incident to the 
RFMLRKS ON DISEASES OF DOGS. $16 \%$

ranine fraternity, but simply those, which may ve iderified by the non professional, miner stood by the inexeperienced, and relieved with out medical advice.

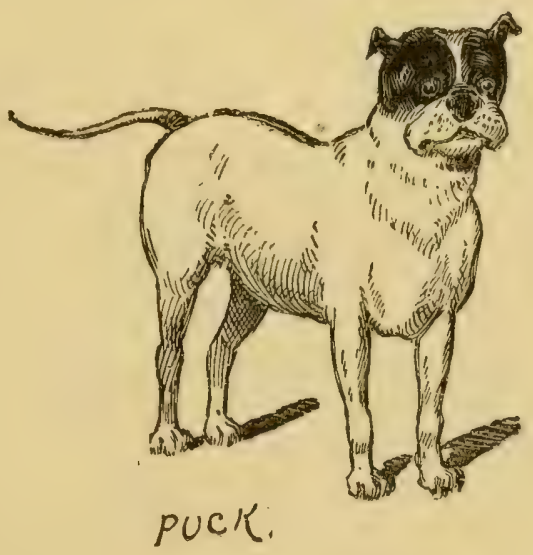




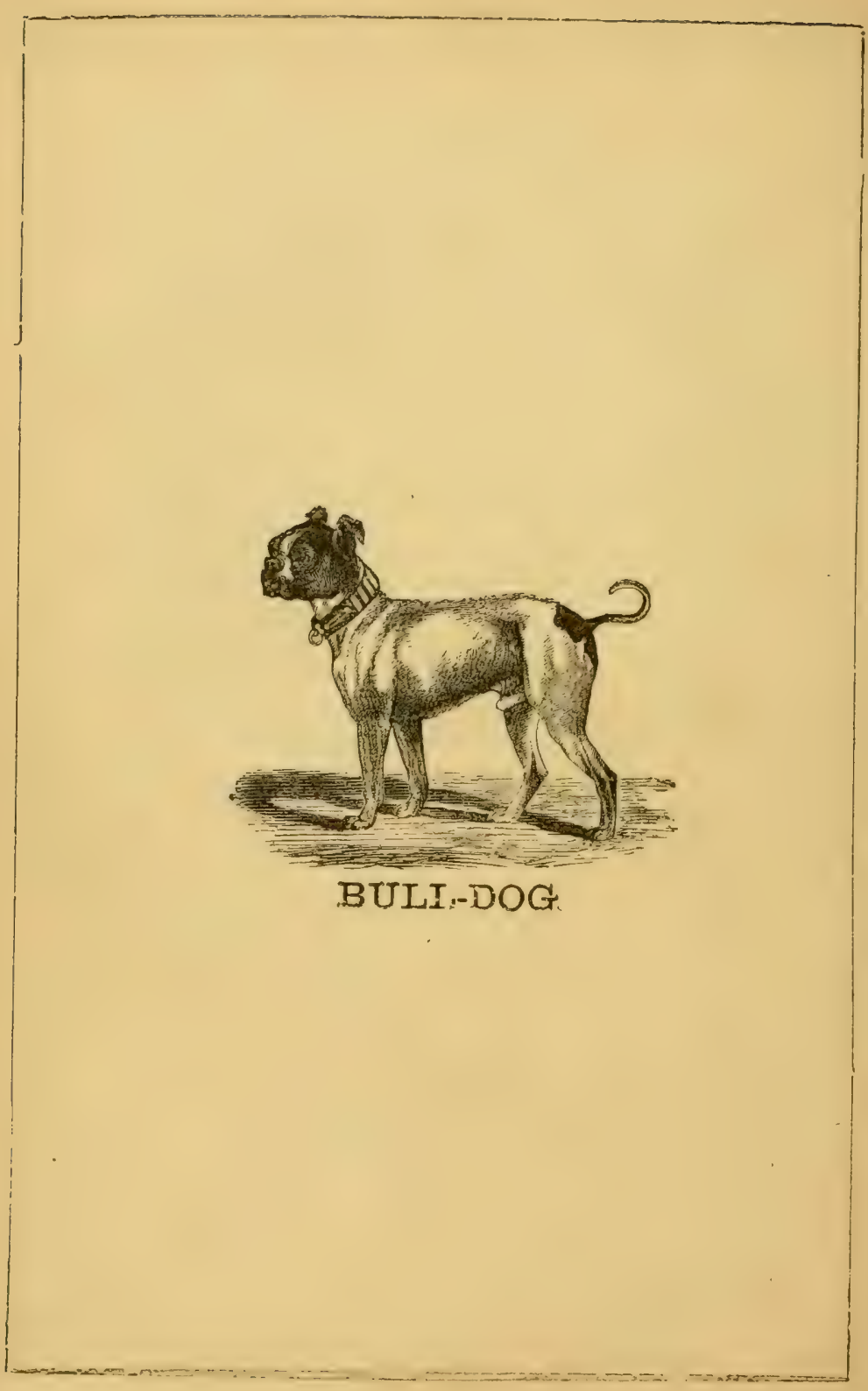




\section{BULL-DOG.}

Sullan, morose, unsociable and grim!

Show me the man, who'd dream of trusting him !

With ahort anub nose, full, treach'rous glaring cye.

Projecting teeth, small ear and forehead high :

Capacious chest, with muscle, well displayed.

The Boxer's bully, and the 'Tinker's jade;

For them he fights, the scars alone his prize,

True to the last, for them, unpiticd dies.

Exposed his vices, now his merits scan;

The latter real, the former due to man.

By nature true, courageous, serious, stern;

Exeited oft, his latent passions burn;

Rude urchins, educated in the street,

Rowdies genteel, who on the corners meet;

Some men of sense and title too, in fine,

Make crucl pastime of this brave Canine. Concealed to view, and worried, day by day, Trained to the Bait, the Battle and the Fray,

Inured to hardship, 'reft of every friend, His life's a torment, and a boon nis end. Tho' few his social virtues dare to boast, Yet those who know him best, will prize him most ;

While others yap, and yelp and yell, and fly, Carse o'er his grave; "I conquer or I die." 


\section{DISEASLS OF DUGG.}

FITS.

ALt breeds of dogs are more or less sulject to Fit: although among the coarse mongrel kinds, they are but little known. Dogs of fine stock, of tender constitutions, those glutted with rich fond and lacking necessary exercise are its most common victims. I consider fits to originate in the lack of a regular circulation of the blood, or from an overcharged digestion, perhaps more than from any other cause. A weak-nerved dog, who is much confined in the yard or house is over joyed at the chance of an unlimited romp, and becomes so highly elated as to cruse an extra flow of blood to the head, causing a temporary pressure on the brain, thereby rendering the sufferer wholly uneonscious even of the prescne of his mater. This 
I beliere to be one cruse. Another is a disur ganized digestion, (more or less deranging every part of the system), striving to vent itself by forcible efforts to expel an overflow of vitiated humors. A third cause is an exposure to the sun, acting more immediately on the nerres of the brain. Fits are often confounderl with Distemper, of which they are ofttimes a dargerous accompaniment. Distemper-fits are quite of a different character to those of which we are now speaking. In all my experience and experiments, I have hit on no antidote or sorereign cure for these uncertain ebullitions of subverted Nature. I will first speak of prerentives, before I propose a method of cure. Animals that are subject to lits should be allowed plenty of excreise (within certain limits), and should be fed on light fare. They should not be exposed to the sun, and great attention should be paid to their bowels, which never should be constipated. 'They shonld never be fed to the ful!, nor on any indigestible food. Wet feet will suddenly bring on fits, especially in dogs who have been long entined. I have often noticed how soon these fits were brought on by their feet sudden- 
ly coming in contact with cold water. If a dog subject to fits be too fat, his flesh should be immediately reduced by light purgatious, his diet changed, whilst he is gradually habituated to an increase of excreise. He should be ridded of every thing tending to annoy him; he should not be exposed to any excitement, and should he appear to he more joyous than usual, he should be immediately checked, stilled or chained. By noticing this, he may generally be spared the trial. I am speaking now of fits, where no distemper exists, as distemper-fits require a somewhat different treatnent. Heated rooms are very productive of these attacks, especially where the ereature is "llowed to lay under a hot stove. Basking in the sun will often bring them on. Dogs are very apt to get bewildered by the sun, and I have often had to remove them from their dangerous fascination. However, with dogs who have no predisposition to fits, I imagine there is not much to be feared from their spontancous baskings. 'Tlıe antidotes then are light fare, regular exercise, freedom from excitement, liealthy stools, avoiding the hot sun, wet feet, \&c. In the majority of cases, previous to a fit, 
the dog has a wild staring expression, and appears to be somewhat alarmed at every thing he sees: he will sometimes stagger and run backwards and forwards without an ob. ject; he may then perhaps stand still, his visiou and hrain eridently wandering : he may start in any direction before he falls, or he may occasionally fall, without any previous in. dications, He will often make the most distressing yclning, both before and dming the paroxym, whilst at other times he will be comparatively noiseless, except from the champing of his jaws, from which he ejects a slimy froth.

Thousands of poor brutes (only temporarily deranged), have been destroyed for being gnilty of Hydrophobia, although it bears but a very slight resemblance to Fits. Ordinary Fits a very sudden, give but short (if any) notice of their approach and the animal either specdily returns to his consciousness or expires. A sulien, morose, unsociable change may be the forerun. ner of Madness, but previous to a Fit. the suf. ferer is generally more profuse and urgent in his professions of friendship. The owner of an animal who is sulject to Fits, slould alıays be prepared with a chain and collar, whenerel 
he takes him ont, as he can then the more readily secure him and manage him withont difficulty. He will thus avoid having him slanghtered, under the popular hne and cry of " Mad Dog."

Althoum the snapping, foaming, staggering, kicking, yelping, should not be mistaktu for Hydrophobia, yet I would particularly adrise all those who may be treating a patient in this condition, to aroid being bitten ; for two simple reasons. First. 'The bite of a dog in pei'fect health convers with it a certain amount of poison, exactly in proportion to the state of the system, upon which the impression is mate. Secondly. Great caution is required to aroid the bite of an animal in this stultificl contition, and I am further perfectly satisfied, that his lite under such eircumstances would he more likely to prove serious, on account of his dis. ordered state; althongh there need certainly fre no ground for alarm or apprehensions of Hydrophobia. Still as dog-lites unrter any rircumstances are far from agreealsle, and furthermore, as the beast is then unconseions of his actions, and especially ungorernablo in his fuifs, his dental operations should be carefully 
Arouded. He may be safely held by the sack of the neck, or kept at a respectful distance by means cf a chain and collar; or should he bo too powerfnl to manage in this way, he may ?: made fast to the first convenient hold. WVith sluts, Fits often prove fatal to Breeting; cither by unfitting the animal for healthy propagation, or destroying the embryo. From such I recommend you to aroid breeding, both dogs and sluts. I would also, advise all owners of confirmed uncuralile fitters (if such there be), to administer a dose of Strychnine, to stay all further procecdings.

The cure must be somewhat similar to the prerentive, with a few simple additions. When he is first attacked, pour a stream of cold water on his head, and immediately put him in a dark place, (or cover his eyes). Give him an emetic of common salt, as much as he can swallow at once. The next day, admin. ister small doses of castor-oil, every two hours, until his bowels are thoroughly, though gently purified. Bleeding may occasionally be re. sorfert to. A little blood may be taken from the ears $01^{\circ}$ tail ; a fly blister may be placed on top of the head, Or a setou introduced in the back 
of the ncek. Should these fits be found to procend from worms, the above treatment need not be followed. The worm medicine should be first administered, where you have any doubt about the case. Should worms be the cause, some of the preventives proposed. would be powerless, though certainly notinjurious. I have found rubbing to be rery effectual in restoring them, when they have been apparently stiffened out for death. A little brandy and water, (say one fifth best French brandy), sweetened, and a teaspoonfiul more or less, administered every half hour, is often of essential service. Nothing, howerer, shonld be given during the convulsive action of the fit, or mil the animal can swallow with adse?. 


\section{DISTEUPER, DIATRHEA, CONSTIPA. 'TION, STOPPAGE.}

"Distemper" is a term, with which well nigh every owner of a dog, is perfectly intimate, but the exact source, cause or origin of the discase appears to have baffled the most profound researches of the "Dogographici" and the Anatomist, to have puzzled the public at large and completely mystified the linowing ones. Nerertheless, a thousand infallible cures are reccipted for it, the majority of which are admirably calculated, either to hurry a suffering canine out of a miserable existence or render him a cripple for life. Distemper may be attributed to a variety of causcs. Like fevers, measles and small pox, it may be corsidered both infectious and contagious, yet, is still of tener a spontancous outburst of disease, origi. 


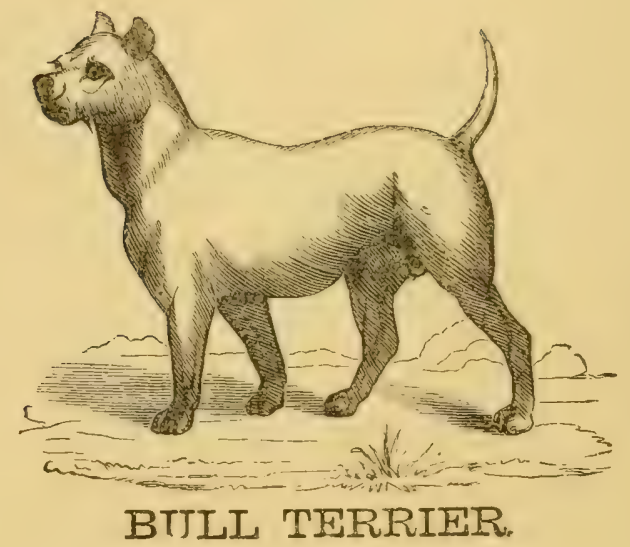




\section{BULL TERRIER.}

In him, the Terrier and the Bull we trace,

Well known to all, his famed, tho' compound

\section{race ;}

The glugrish Bull-dog, thus, new vigor gains;

'The Terrier ton, the former's pluck retains ;

Thus stubborn courage and deliberate nerre,

To check the hasty and impetuous serve.

A Mongrel true, yet, tho' a Cur he be,

If right his stamp, no better hound than he;

Defies the water, braves the very fire,

Unites the merits of his Dam and Sire.

'To fix his size or color. were a jest,

Yet true it is, the smallest sclls the best;

A doubtful title, but which some concede

'To ought that bear's a shadow of the breed;

Of colors all, weight forty pounds to three,

T'oo dwarfish for an honest pedigree.

Apt as a scholar, faithful as a friend.

ii ell armed and ready, raliant to defend;

He knows no danger, and he fears no foe, And if vindictive, man has made him so;

His instinct ever, on his duty set ;

True Courage never was a Bully yet.

Shou'd any doubt, if this be true or not,

Peruse the writings of Sir Walter Scots 
nating in the system itself; yet from what par. ticular infuences, has not yet been satisfactorily determined. No antidote or safeguard ngainst its attacks has yet becu brought to light, neither has any sovereign remedy been effectual, in averting its fatality. The malady presents itself in such raried forms and types, that it is often not recognized as Distemper, even by those who have had some experience in Dor-kecping; whilst other and widely different ailments are often attributed to Diatemper. Its appearance is not confined to any age, season or climate, neither is it peculiai to any breed, or the result of any particular kind of diet, locality or management. One breed is ag subject to it as another, yet certainly not equal. ly liable to becone its victims. The worthless mongrel stands a far better chance of recovery than the appreciated pet or the high bred Sporting-dog. The reasons of this to me are eri. dent. 'The cur' is hardier', from his cross-breed and habits of cxposure, and is naturally of a stronger constitution, conscquently, the better fitted to resist disease; is seldom pampered and gorged, gets more exercise and less physic. High bred dogs are always somewhat difficult 
to rear. There appears to lack in them a certain rigor of constitution. in which the cur is seldom deficient. For this reason, great care is requisite in the raising of choice breeds, till they attain their growth, or pass the ordeal of Distemper. It must not be supposer howerer. that all dogs must of necessity hare the disease, any more than all children are bound to have the Small-pox or Scarlet fever. Again, some hare it so lightly, that it is scarcely perceired, whilst others makeshort work of it, and snuff out in a canter, in spite of all efforts to sare. The common symptoms are restlessness, heariness, disinclination to more, redness and someimes great paleness of the ere, whiteness of the gums, runniug at the eyes and nose. loss of appetite, looseness of the howels, dryness and dirty appearance of the nostrils, dry cough, wasting of the flesh and general debility. Ulcers will often appear ahout the lips and gums, the breath becomes offensive, and the erac. wations have a putrid odor. These indications do not appear at once, nor in all animais, neither can Distemper always be traced, when some of these symptoms are apparent. After all, the general appearance of the patient 1 s 
enore to be relied on than any one of these diz temper-like appearances. A marked difference will be perceived in the general deportment of the canine, which any olserver of his general habits will not be at a loss to interpret. His owner should be in the habit of kecping a strict watch on him, now and then for a few minutes, without engaging the animal's attention; as dogs, like men, are prone to wear a merry com tenance, when the system is diseased. It is therefore necessary to sean their spontaneous movements, which is the plan I invariably adopt in discovering the most important of canine ailments. Of course their various parts may be likewise cxamined, in order to ascertain the rery spot, where any disorganization may more visioly develop itself. Distemper ap. pears to be more fatal at some periods than at others, without reference to any particular season of the year. I have however found it more fatal in the fall of the year than at any other season, especially on the first appearance of cold weather. It may attack a litter of puppies, some very lightly. some severely and others fatally, yet these have breathed the sane air, eaten of the same food, orcupied tho 
sane beil and received the same treatment. Who then shall prescribe an antidote against its inroads, or an absolute remedy against its fatality? Its effects nerertheless may in most cases begreatly mitigated by constant attention to the health of our charge, forbidding the least indisposition to pass mnoticed, and hy resorting (as occasion may require) cither to gentie aperients, wholesome astringents, or moderate abstinence. I an arerse to administering Calomel to dogs. It is decidedly dangerons, and thousands of poor animals have been sacrificed by it: it can only begiren with comparatire safety. where the animal would he subjected to no kind of atmospheric change, and this would be rery diffenlt to aroid, as his coat cannot he conveniently thickened to suit the weather.

When a whitish mucus fluid runs from the nose, it is almost invariably a sign of distemper. This may be generally considered a farovable symptom, and far more favorable, than a dry hot nose, emitting little or no moisture: in which case I have often found the diserse settled on parts more rital and more difficult of relief. I beg of you not to consider Distem 


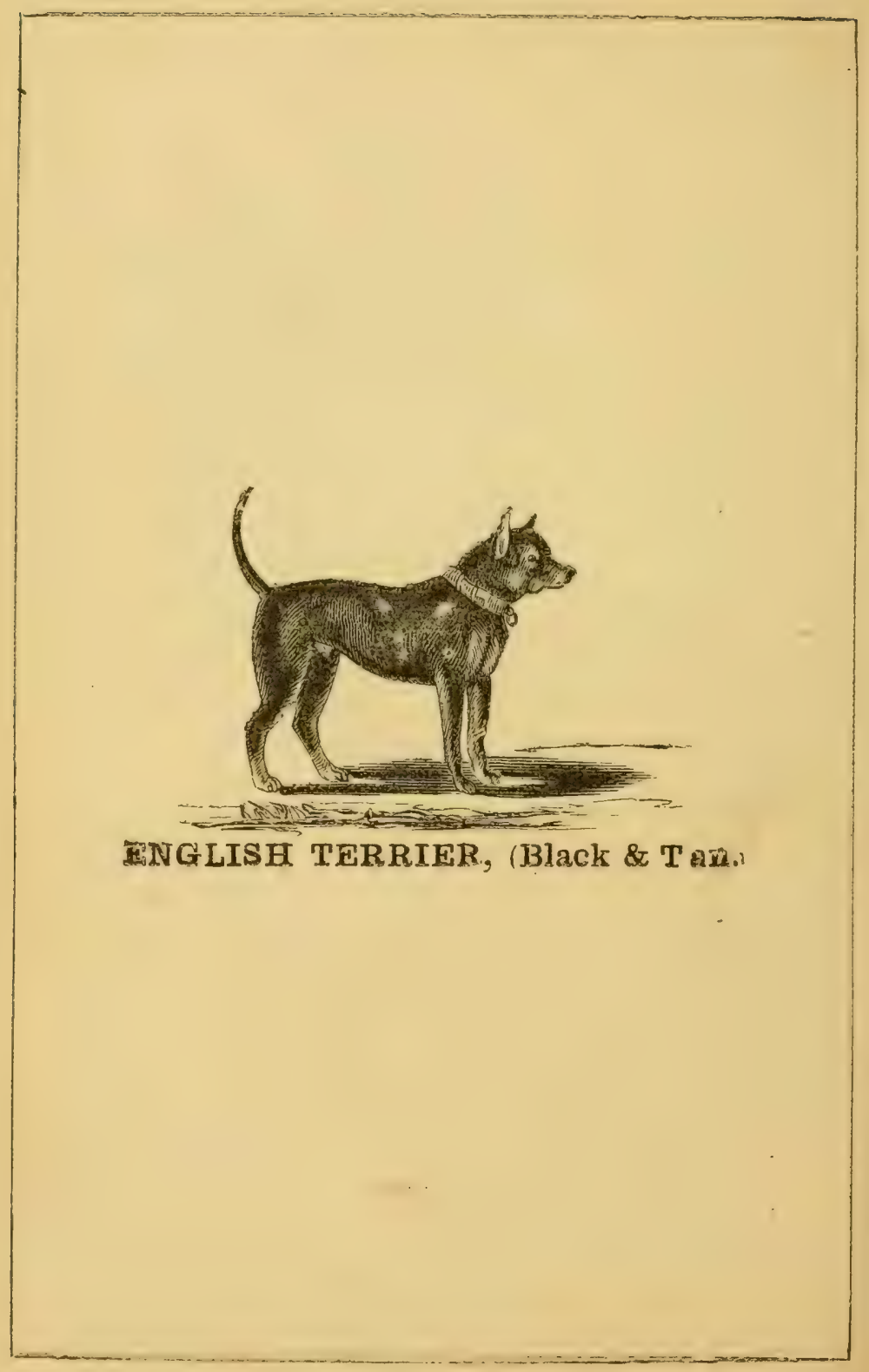




\section{ENGLISH TERRIER, (BLAOK \& TAN).}

of varied color, fashion black and tan,

In England, (say they,) this famed race began, Rel, white, nod yellow have been highly prized, 'Thoagh sundry ti,ıts, by man are of'c' devised. Well shaped his form, with Greyhound-taper. ing head,

Leg, bre:ust and jowl, well flushed with tannish red ;

His body black, with coat, high glossed and fine,

Varying in weight, from twenty pound, to nino. If ought of white his feet or breast disgrace, Too light a red or brindle there we trace; 'Too ciurnsy limb, too coarse his tail or coat, Doubtful his Sire; his purity remote.

Staunch and couragens, daring in his ways, Quick as a flach, the noisome rat he slays; His stern endurance oft' has proved him fit To slungiter hundreds in the graming pit. Of late contrivance, springs a dwartish race, Fitted alone the drawing room to grace ; Of tender growth, yet cleg:int in limb, Active and sprightily, vigilant and trim, Watchful alarinist, docile, apt and small, Is now Yclept the favorite of all, And oft' reveals the wealth and taste of man, The perfect, pencilled, tiny Balack and tau. 
per, this rumning at the nose, as a gimple dig. ease of the mucus membranes. The origin is not there; it is a general attack on the whole system, commonly originating in tho stomach. Nevertheless this rumuing ought to be encouraged, by often sponging off with luke warm water, especially when it cakcs around the nostrils, after which a little swect oil may be rubbed on them. 'This appears to have but little to do with the cure of the discasc itself, yet it is a great relief to the animal, facilitating his hreathing, and conscguently di. minishing his sufferings, thus in a measure cuabling him the better to withstand the malady. 'The principal object in Distemper (as with many other discases) is to keep the bowels in a proper state, by preventing the system becom. ing too debilitated to outgrow its attacks. 'The seat of Distemper being principally in the digestive organs, the stomach must be the principal olject of our solicitude. The food should be nourishing; yet easy of digestion; a little should be giren at a time, say three or nore times per day. according to the strength of the patient, lut not to interfere with the operation of modicine. Exposure to ret, cold, or damp 
is very much against recovery, likewise too much heat or close confinement. A little exercise is benelicia!, but this need not be forecl. As I have just observed, presuming the seat of the discase to be in the stomach and bowels, let us attempt a cure by first cleansine and thoroughly ridding them of all purulent offensive matter, which I have found to exist in all distempered dogs. 'This must not be effected by too powerful means, as Nature is more iujured than benefited by drastic purges, and often disibled in her efforts to recruit herself. Aroid then strong doses. At the outset of the disorder however, an emetic must be resorted to, to cloanse the stonach. Common table salt will have the desired effect. One good throatful, or as much as can be gulped down at once is generally sufficient to produce vomiting, and should be the dose for any dog, of any size. You need not be alarmed at the quantity, as it will almost invariably be reject. ed, when given in large doses; or will some. times act, both as an emetic and purgative, in which case no other aperient will be required for the time being.

I propose then to cleanse the stomach the first 
day and give no other medicine. Take care that the patient have plenty of cold fresh water to drink, light farc, beef soup, with rice or pilot hread well boiled in it. or according to the dog's mode of living, with more or less of meat, but well cooked and well mixed. so that it be not eaten alone. Where there is a tendency to looseness, raw flour may be tied up in a fine cloth and boiled for three or four hours, after which it may be mixed in with the soup. It is . not so common for dogs with Distemper to be constipated in their bowels; the reverse is generally the case, and has frarticularly to be guarded against, after the system has been thoroughly cleansed. In many distemper-cases, the dog has a ravenous appetite and appears to decrease in size, according to the amount of food eaten, clearly proving that it passes off undigested, thus leaving the multitudinous parts of the system wholly unprovided for, and the whole frame to wither away. The sccond day castor oil in rery small doses should be admin. istered every two hours, till it operates freely, say, from a quarter of a tea-spoon to half a table-spoonful at a time, according to the age and size of the animal. Should he be rery 
costire, the doses may be doubled. The less medicine giren in Distemper, the better, nerertheless what is necessary, must be done. Sufficient warmth, perfect cleanliness, freedom from damp, light diet, and a comfortable bed are essential to a fair prospect of recovery. The strength must he kept up as moh as posibile, by feeding little and often, but never as much as the dog would eat. Yon need not be uneasy about lis dying of starvation; he is the last animal in the world to dream of committing suicide. If he will only eat a little, he need not be forced, except on particular occasions, such as his absolutely relusing all manner of food for a day or two, in which case a little strong beef soup may be fed to him with a spoon every hour or so. Fits are very common to dogs with Distemper, and still more common to those who have it not. As an accompaniment to Distemper, they are far more dange. rous; but let us once see the digestive organs right and all the dependencies will follow suit. In wounds and local attacks, local applicatiots may in a measure suffice, but in distemper, the righting of the whole machine must we effected at the main spring. For distemper-looseness. 


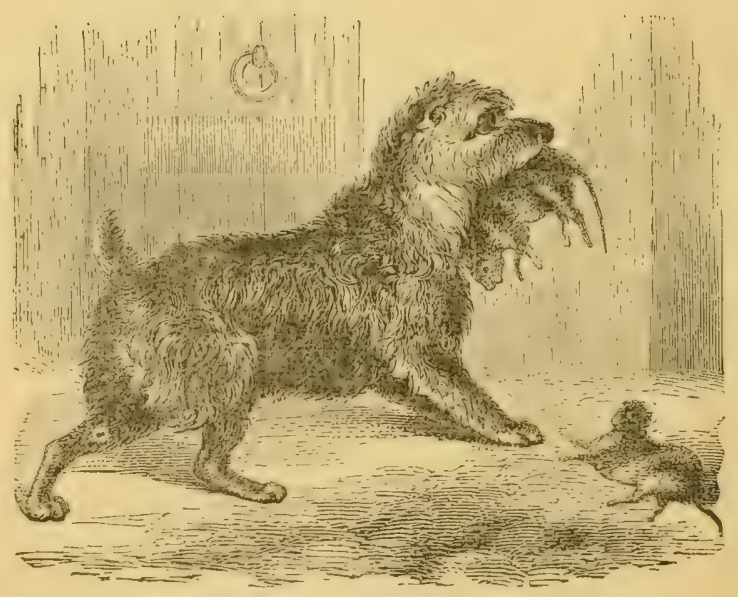

SCOTCH TERRIER. 


\section{SCOTCH TERRIER.}

Small, rough and whiskery, and of santy he Though sometimes gray, and oft' of dusky blue; Clear, bright, inquisitire, sagacious eye, Moustachiod lip. with brows deep sianled by ; Brave. hardy, vigilant and ever gay,

First famed on Scotia's lofty hills, they say : Kills for and weasel, sknnk, racoon and cat, Rabbit or squirrel, hedgehog, mousc or rat ; Onirard he rushes, with impetuous ire, His wiry pelt dares bramble, bush and briar; Through matted brakes, he threacla his thorng way,

Digs in the earth, or te'npts the flood for prey; Not swift of limb, the flecter game to trice, Attacks the foe, within his hiding place; of noxions vernin rids the house and storeInspects each corner, searches every floor'; When cumning Renard, pressed by boisterous hounds,

Rushes to earth and thus the pack confounds, I'he valiant Scot assails him in his den, All grore-lyegrimmed, he drags him forth again. His coarse exterior, some may chance contemi, Others his blunt expression may condemn; Yet none his virtues ever dare deny ; IIis merits rigid scrutiny defy. 
diar'rnoen or dysentery, the best renedy I have . found is the proof Frencin Brandy, gromel allspice and brown sugar, viz: a gill of French Brandy, a table-spoonful of ground allspice, nud a heaped table-spoon of brown sugar. Mix the allspice and sugar in a sancer and stir in the brandy. Place this saucer and its con* tents on an inrerted saucer, and set fire to the ingredients, and stir gently till the fire goes nut. When cool enough, pour into a bottle: shaking it well, every time you pour off. Give the patient from half a tea-spoon to half a table-spoonful in twice or three times the quan. tity of water, every hour or two, till the loose. ness is checked. If the animal should be at any time ton costire, gire small doses of castor oil as before recommended. With these simple remedies, the enemy may be kept at bay, and Dame Nature will have a fair cliance of minding her own business, In a healthy dog the nose is cool and moist, and is consequently "very fair index to the general health; although when the animal is consumptive, or much reduced in flesh, the nose, cars and ex. tremities are all cold, from a lack of the power of general circulation. Snall stimula tire doses 
nre then very usctul; a litlle weak, well-singar. ed brandy and water, every hour or two, with ol without strong beef tea. according to neecs. sity. Looseness is far more dangerous than costiveness, and far more difficult to arrest on a sure basis, as it should by no means be too suddenly checked by powerful astringents. 'The hrandy and allwpice compound before recommended, I consider to be the safest and most efficient. With this I have not only cured the most obstinate cases of Diarrhoea, but have restored animals, who appeared to have breatled their last. I once sharpened my knife to skin a farorite King Charles' șmaniel whom I supposed to be breathing his last, lut suldenIy changing my mind, I gave him three doses of this compound, at intervals of half an hour. Ifter the first, he kicked out his hind leg, after the second he olightly laised his head; artel the third he tottered off several yards, and from that hour rapidly recovered. Remember, I ain a powerful advocate of little and often, in all rases of prostration from riscase, more especially in Distemper. Nature in an exhausted state is paralyzed by powerful doses, whilst she appropriates adraitageously the 
\&entle droppings. If stoppage should not. yield to smail hourly doses of castor oil, the bowels may be well rubbed, with brandy spurits of turpentine, or alcoho! with spirits of camphor and ether. An injection of blood-warm soap-suds may he used and repeated every fifteen minutes till an operation is effected. Should this not succeed (and the patient be not inconveniently laroge), give him a bath, as hot as he can readi'y bear it, for fire or ten minutes; after which, rub him heartily and thoroughly dry : keep him well covered, till he has entirely recorered its effects and a natural reaction has taken place. I have howerer, very rarely failed with small doses of castor-oil, which I have occasionally perserered in for thirty-six hours. Of course on the first indication of relief, it must be stopped and small doses of light nomishing food be substituted. When the distempered dog shows heariness about the eyes or giddiness, he should not be exposed to much light. As what eftects the eye, eflects the brain and what effects the brain acts on the whole system. A slight aftection of the brain, requires in a dos, but litile outer excitement to prodnee fits, which tendeney shonld be cliceked. as much as possible. 
Fine bred pets are very easily unnorved. especially when in a delicate state of health; quietness is as essential to their recorery as to a human being in a similar condition. I) not presume that all fits have any connexion with distemper. They often arise from a naturally weak and nervous temperament, and oftener still from indigestion and worms. The latter may gencrally be known by a tightness of the belly, (especially in puppies), irregularity of stool, sometimes lonse and sometimes the re. rerse, jumping durings sleep, a rumbling noise in the inside; by the animal dragging himself along on his hind parts, hy his suddenly yelping and changing his position, and by tho oft renewal of his yelling. These symptoms have seldom any thing to do with Distemper, thongh they may sometimes co-cxist with it. The worms shonld be got rid ol first and Distemper afterwards, should both be visibly marked together. Worms, in young puppies are often mistaken for Distemper. The looseness arising from worms should not be cliccked, till the worms are expelled by medicine. Stoppage is also caused by worms, by solid knots of them blockading the intestines. As the worm 
medicines I recommend moler the head of " Horms," are not calculated to injure the con. stitution of the most delicatc, it may be safely administered whenerer worms are suspected. Dogs have been inoculated for Distemper, lut I have not heard of any lenefits arising from it. In raising Sporting-Dogs, my plan is to in troduce them to the discase, when they are in a healthy state, but not when the disease has assumed a virulent form, I think the most farorable time to be just after they have finished shedding their teeth. They are then generally in a healthy condition, and on that accomnt the disease seldom prores fatal; to say nothing of our heing fully prepared to treat our paticnts accordingly. It is very rare indeed for an ani. mal to contract the disease twice, thomgh it may often return, if it has not been judicinusly or thoroughly eradicated. I would advise those then, who would raise Pointers or Setters, to foree them into Distemper at a suitable period, as it is more particularly trying to lose a sporting-dog, after the trouble and expense of rais. ing and breaking; to which may he added the blighting of our lone cherished hopes of an invaluable field companion; but ou no accoun 
expose him to the Diseade, till he present hia new set of teeth, as they are often totally ruin ed by its effects; not only the oreans of mastication, but his breath, his health and his beauty. Setters, Pointers, Greyhounds and Newfoundlands are more sererely affected by Distemper, than the ordinary breeds of Dogs. Their food in early life should not be too gross, neither should the stomach be overeharged; for although, as I have before observed, there be no antidote against Distemper, yet its attacks may be mitigated by attending to the general health of our farorites. We must first he careful to procure healthy stock, keep them on wholesome food, neither stuff nor starve them, keep their ears warm, their noses cool, and their gums rosy; neither compel them to be hot or cold, wet or exposed.

In Distemper, the matting up of the eyes should be cautiously guarded against; by often washing with warm milk and rubbing a little sweet oil on the lids. When the animal cannot see, his trouble is licightened, and the whole nervous system thereby affected, and as dogs are very sensible and sensitive animals, endowed with almost human intellect, we must 
remember that whatever tends to cheer and enliven them, has a happy effect on their lihysical ailments. When the heaviness of the head is not relieved by aperient medicines, the crown of the head may be shared and a fly-blister placed thereon; a little blood may be taken from the ears, or the head may be often bathed with cold water and carefully dried off. Howerer, I do not recommend bleeding, execpt in extreme cases. Instead of a seton, so much recommended by Dogologists, I prefer passing a sharp red-hot iron about the size of a learl pencil throngh the skin at the back of the neck, leaving the wound to fester; it often has a haply effect, in relieving the head and carrying off the humors. It may be allowed to lieal of its own accord and reopened, if requisite. If any twitching or shaking of the limbs shonld come on, it should be immediately taken in hand, and every means used to keep up the circulation, ly rubbing in a strong liniment, composed of spirits of turpentine, alcohol, oil and laudanum, or if nothing be used, the frietion alone will he serviceable. "Butler's Mange Liniment," has been used with great effect, in such cases. In this state, especially, the animal 
should not he exposed to any kind of danp ; the bowels should be kept in a proper state, the foor shonld be light, he should be carefully supplied with fresh water and a confortalile bed. If the weather be farorable, he should have as much exercise as he ean enreniently bear. These nervous twitchings, if not attend. ed to in time, are difficult to cure, and eren with all our precautions and attentions, are always to be dreaded. When they neither yield to care, medicine, diet or friction, the poor sufferer had better be put out of his mise. ry. I have had valuable patients lying helpless, for many montlis, long after the whole hind parts were completely paralyzed and lifeless, and have at last been induced to destroy them by drowning, the only method of proving whether their limbs might erer regain their motion. in the agonies of dissolution; but the sufferers have invarially sunk, unveighted to the hottom. Light twitchings happen to dogs occasionally, when they have no Distemper, and often depart without help. For this I have found nothing so good as rublung and warmth. Mange and other cutaneous erup. tions are considered by some writers as fore. 
runners of Distemper. Distempered animals often hare postules on the bowels principally, but they have not the appearance of ordinary mange. When these postules lreak nut in Distemper, it is far from a farorablesympicm. 'They should be treated howerer, as Mange, and great care should be taken of the sick one, as he is then more liable to take cold, than at any other period. Distemper is more apt to be fatal with animals ferl on a rank meat diet, but do not suppose that any food is an absolute preventive; I have seen hundreds die, who nerer tasted anything but cracker and milk, and many indeed, who never lived long enough to eat anything at all. Dogs are very rarely hlimbed by Distemper ; the bluish film which often covers the eye, naturally disappears, as the animal recovers, and it is far better let alone, with the exeeption of gently washing with warm milk and water. If a dog be taken with Distemper, he should be removed from his companious, to avoid infection, though I have found this to be no positire guarantee, as the canses originating it in the one, may equally operate on another. and Distemper may be lurk. ing in the system for wecks, before it makes a 
decided appearanse. I could entemerate a bost of Distemper remedies, but as my object is to simplify, J shall not eularge on tinoir сёрестіке virtuen.

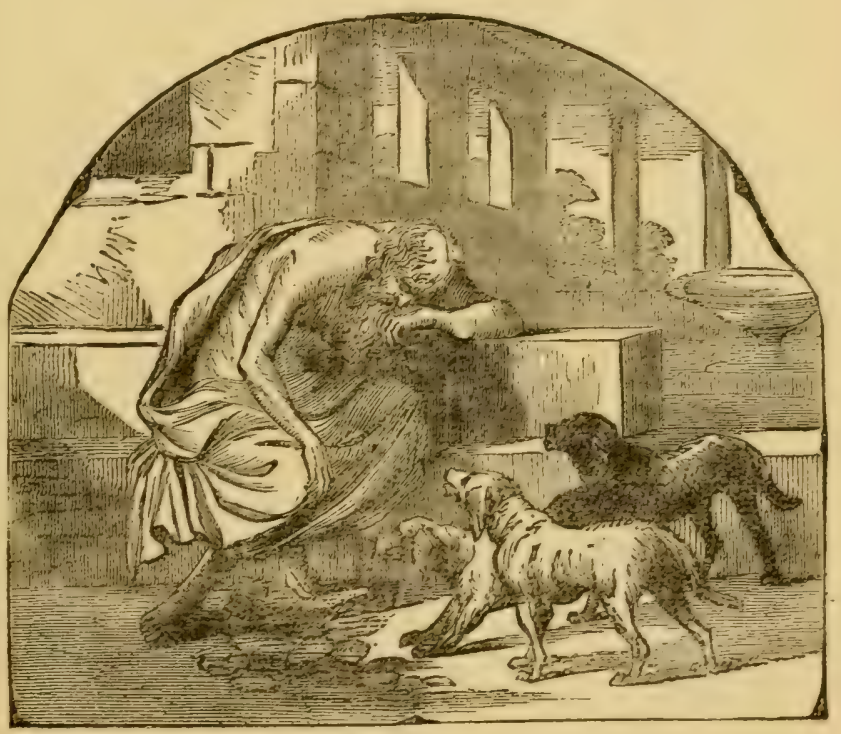




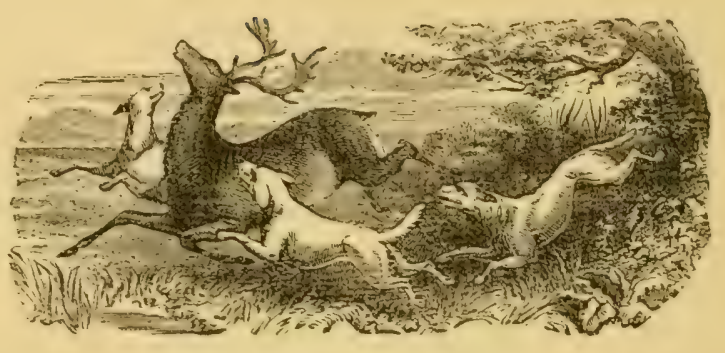

MANGE.

Next to Distemper, Mange is the most common and the most troublesome disease, that Dogr dom is heir to. No breed, no age, no size is exempt from its attacks. It is propagated in a varicty of ways, and is to a great extent hereditary. It is also contagious, is spontancously produced by gross feeding and dirty bedding, and is sometimes an appentage to $D$ is temper. I have seen puppies, corered with Mange sores on their entering the world, entailed on them lyy their sire or Dam, or per. haps even of origin more remote. $\Lambda$ dog, by simply lying where a diseased animal has been, may become contaminated, or by coming in contact with him in the street. Fortunately, it caunot be taken by any human being, (a: 
least I have never known a case), any more than the Searlet Feres can be conreyed to a dog. 'It is very similar to the Iteh, in the human l'ace, and I should think surpusised even the genuine "Scotch Firldle." I have good groumds for believing that ordinary Mange, is produced by insects. generated in the blood and hrought to life on the skin. Of the secret of their formation, I confess my entire igno. rance; but as outward applications are far more efficacious than anything taken iriternally, and as one rubhing with the Nange-Liniment allays the irritation, I am still further con. rinced of its being an animal prorluction. Are not inscets visibly bunght to light in the same way on the surface of the human body? The tendency of the secretions of the system to produce tir sc animalculie may cer. tainly in a great measure be arerted, by licep. ing the body in a healtliy state, so as to check auy stamancy of the juices, which favors the spontancous production of animal life. Whole. some and moderate fare, exercise and cleanli. ness are the grand preventives, "Butler's Mange Liniment and Flea Exterminator" is a Eovereign cure, as it not only eradicates the 
MANGE。

discase, but speedily reproduces a superabun. datice of hair. But I would recommend both preventivez and cure. As the Discase is principally caused by impuritics, perfect cleanliness must be attended to without, and all grossnesg aroided within, where there is any indication of eruption. If "Butler's Mange Liniment" cannot be had, Oil of Vitriol, diluted to the strength at which it can just be borne on the tongue, without burning, to which add a quarter of an ounce of finely ground Indigo and a quarter of en ounce of Gunpowder, (mixerl well together), to a quart of the diluted Oil of Vitriol. The animal should be first weil washed (if the weather, \&c., be farorable), and then rubbed all over with the mixture, every other day. Every alternate day, he should be well anointed with common fish $\cdot$ oil. An ointment of Sulphur and Lard is another remedy, but I object to Sulphur, as it often strikes to the limbs of the animal, injuring him for life, go if this be used, he should be carefully kept from taking cold. It is preferalle that he should be washed, before every application. Whaterer be used. the beast should be rubbed from the tip of the nose to all his extremities 
and the mixture must be well rubbed in. " [Butle:'s Mange Liniment," never fails to produce a heautiful coat and to allay the irritation on the first application; which I have never known any other compound to effect. Its application should however, be repeated erery other day, for three or forr times, to ensure death to all fortheoming animaleula. No aniinal occasionally rubbed with it, has been linown to take the Mange, and for beautifying the cont and cleasing the skin, its equal is not to he found. Doges affected with any cutancous eruption, should be suljected to a thorough but gentle physicing, and their morle of liring should be entirely changed, in order to give the constitution a fair chance to purify itself, and put a stry to all further spontancous insectile productions anong the sluggish soeretions of a disordered frame

The risible symptoms of Mange are, hare spots. irritation, eruptions on the skin, a shortening. or unnatural falling off of the hair, redness on the back, bowels or other parts. Fleas also produce a kind of Mange, perliaps the most difficult of cure; as they direase and poison the whole surface of the body, and if 
neglected sometimes reduce the sristem to recoverable weakness, by depriving the dog of his necessary rest. Very old dogs are the most difficult to eure.but 1 have not net with an inemable subject yet. 'The disease, howerer, should be taken in hand as early as possinle?, as, to saty the least of it, it greatly anuoys anc disticures the sufferer for a season.

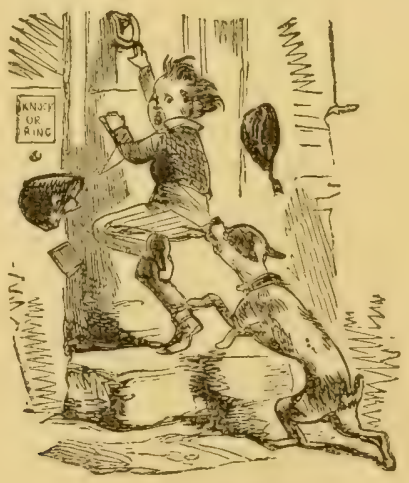




\section{RABIE, HỸDROPHOBIA,}

IT is somewhat difficult to define the taried symptoms of IIydroplobia. Incatitiously to attempt it might perhaps arouse fears, where there existed no canse for alarm. For the consolation of the nerrous howerer, I may com. mence by assaring them, that a mad fiog is indeed a very rareproduction, and that perhap not orel one in a thousand of trose acensed of it may be pronouned guilty. Every ill-bren strect-roving bone-grabber, every dog despairingly secking his master, every canine in a fit, every noor beast, overcome with heat and fixtiguc, erery affrighted quadruped scekingr ro! nge from his mereileas pursuers, in fine, every farorite, who may portiay a certain strange. ness of demeanor, nust of course be mad. In the last ten year, I lave not had a single cas? 


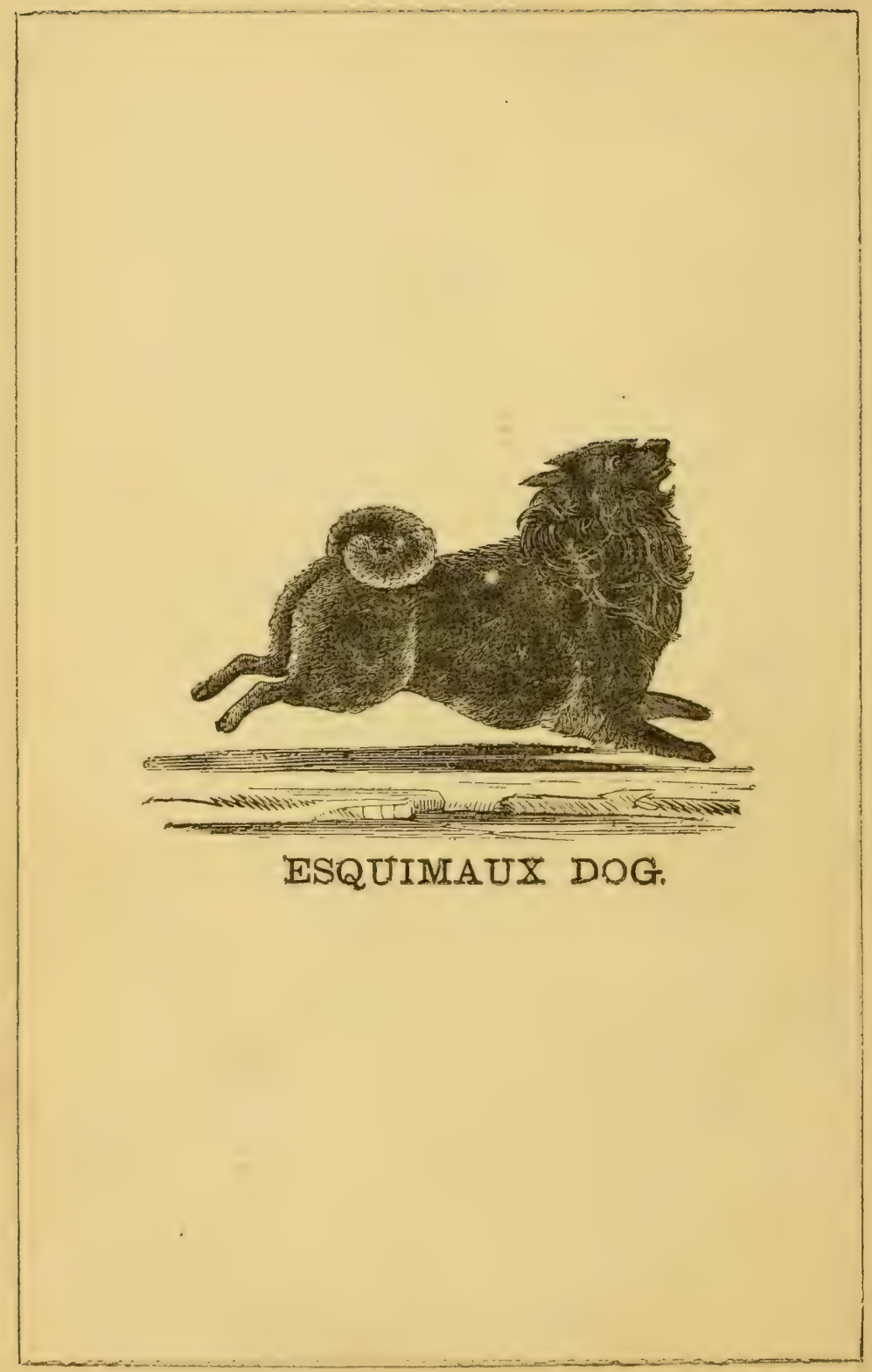




\section{ESQUTMAUX DOG.}

Pet of the Laplander and Esquimaur,

Where dwarfish men aud stunted mosses grow ; Whore winter long extends his dreary reign, And ponderous icebergs choke the norchern main.

Fox-like in shape, nor varies much in size, Short ear erect, sharp nose and cunning eyes ; Or black or white with coarse and leng thy hair ; Condensed hy climate and by scanty fare; Thick bushy tail, flat on his back and curled; 'Tho' in the hour of peril, oft' unfurled ; Lively and active, vigilant and gay, Not lacking courage, anxious to obey ; Spitz, Pomeranian, Arctic, Esquimaux, By various epithets, the breed we know; Yet so peculiar is the genuine race, The least impurity his traits deface; His compact form, thick set, robust and trim, His sprightly gait, black nose and supple linb, His dress unique, his dark inquiring eye, All base ignoble counterfeits defy. In German States, where men most need their wits,

Is most eateemed of all, the watchful Spitz; A bribuless gruard, not oft' with strangers free, 'There's many a hound, that well a Spitz might be. 
of Hydropholia, among an arerage stock of sixty or serenty dogs, under my own eye, nor a solitary case, among some twenty or thirty moie, kept for me by otliers; although I bave had many, which, had they fallen under. public notice, would no doubt have exeited the usual and alarming celo of Mnd dog ! Mad dog!

A racant, wild, sullen expression of the eye, morements to and fro, apparently without an object, a tendeney in the animal to devour that, which he would at other times have left umno liced: unusunl indications of affection, in which he persista, in spite of his master's commands: a marked uneasiness in all his morements : a constant changing from place to place; a dis. position to suap on the slightest approach of nnnoyance: a desire to retire from the presence of any one : an unwillingness to quit his retreat or to come at his master's call, licking his own mine, se., these are symptoms of Hirlophobia. Tet all these may exist in different animals, and not one of them he bordering on madness, Nevertheless, there is after all, a certuin something, in the appearance of an animai with the symptoms of Rahies, that should not be misun- 
derstood by him, who has been accustomed to scan the ordinary morements of his farorite. The decided change which has taken place should not be carelessly disregarded, and when erer any suspicious indications present them eclres, the animal should be securely chained or confined, where he may be out of the reach of everyboly, until the case be clearly defined. I do not mean by this, that a suspected individual, who has already hecome the subject of a marked change of demeanor, should be even trusted with his master's fingers, but that he should be collared and chained in such a way, as to annililate all risk of injury. The eye will generally denote the disposition; therefore where suspicion exists, and before the hand be extended to touch the animal, he should be playfully spoken to by his master, who may gently and jocusely present him some olject attached to the end of a long stick, which will be a fair way of testing his feelings.

He should be exeited by his usual watch words, that he may afford an opportunity of noting his actions. His nsual food and water should be cautiously placed within his reach; in fine, every precaution should be observel. 
lur although cases of $\Pi$ ydrophobia are hajpily rare, the bare idea of it, (as an old lady justly remarked,) is no joking matter. 'Thus, should there be nothing amiss, a great deal of uneasiness may be avoided. Some of the causes of Madness in dogs, I have found to be the following; exposure to the sun, without the power of retreat; depriration of water, especially during warm weather; unwholesone food, remaining undigested in the stomach; heat, excitement and lack of nouishment, accompanied by continued worryings, peltings, and drivings; the constant wear and tear of the whole nervous system, produced ly fleas being allowed to accumulate; the bite of rabid dogs or renomous reptiles; bones or any foreign olject stuck in the jaw or throat. But a more ordinary impulse to Rabies than any of the foregoing, I believe to be the dogged determination of the male in pursuit of the female, more especially when great heat, lack of food and water, and protracted journeyings are added to the torments of unsatisfied lust. Of this I havo known several unmistakeable instances; indeed every circumstance attending these headstrumg peregrinations combines to agitate and 
disoriter the whole nerrous fabric of the natu. rally cxcitable canine. Some years ago, I had three cas s of decided madness; two cansed by the bite of renomons reptiles; the third by a sunstroke. Of course I safely and securely chainel all the patients and markel their daily progress. The two bitten subjects grew worse and worse, till I reliered them by a mereiful death; the third, by my throwing cold water ou her, three or four times a day and liecping her in the cool shade, with little light. gradually recorered, and afterwards prorluced several litters of puppries, one of which lived just loug enough to he swallowed by an alligator on the banks of the Mississippi. Neither of these dogs refused to drink, but the two former had lost all power of swallowing, for some time previous to my destroying them. Ralies, caused by renomous bites or objects sticking in the throat or jaws is perhaps the most incurable, as it is by no means adrisable for the inexperienced to risk an operation, at an adranced stage of the inflammation. I beliere many cures might be efiecterl, if the animals were only kept safely bound in the stade and constantly cooled with water, I mean where 


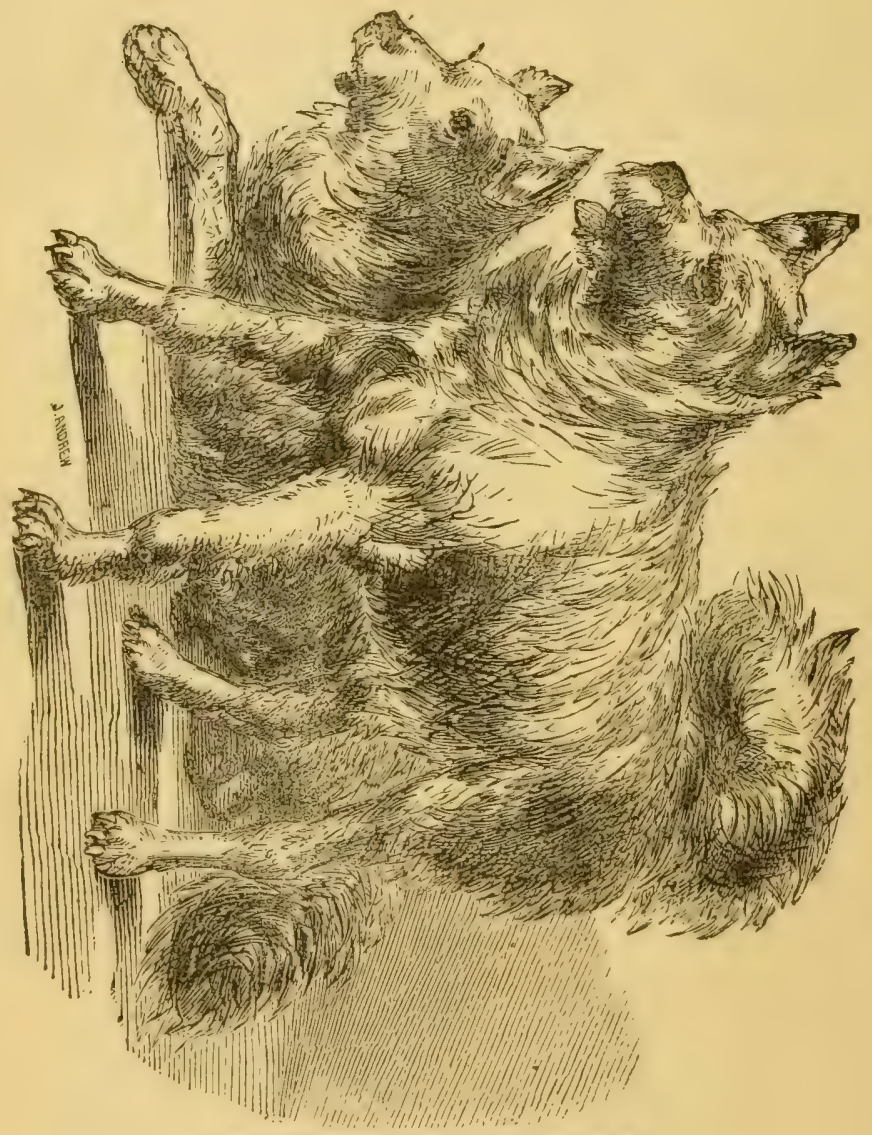

ARCTIC SLED DOG. 


\section{ARCTIC SIED DOG.}

A noted member of the frigid zone, Hardy and tough, adapted to his home, 'I'o him the tratits of horse and hound belong; His feats the theme of many a polar song.

Of wolish form. ret somewhat stouter grown; The sled dog, solo in Aretic regions known; With stiffened car crect, keen prowling eyc, Sharp pointed nose, and coat of raried dye; His dress compounded of a woolly wire, I)fying cold, disdaining sun or fire :

In vigor strong, to hardship c'er inured, lirom pampered taste and indolence secured; of lasting foot, with firm and nervons tread, Unwearied dracgs the cumbrous I appland sled. Or lightly bomding with the travelers' sleigh, With gladsome trip, makes seventy miles a diy. Pary, MeClintock, Belcher, Ross and Kane, With thankful lip, recorl his memoricil name; O'er Greenland snows and ice ol' Baffin's bay, Hungry and graunt, he led the trackless way. For ever barred the sweets of home to taste, Triumphant sperl them throngh the frigh waste, $\mathrm{O}^{\prime} \mathrm{er}$ the brave Franklin, raise one grateful sigh!

His faithiful dog lies bleached and withered by. 
the cause may be indigestion, over-excitement or sunstroke. When an animal has been bitten by another, known to be mad, I consider it un. doubtedly the safest method to destroy him: although I have known many dogs, which have never becn affected by the bite, whilst others have hecome its rictims.

Dipping in salt water, three times following, each time kecping the patient under till he is nearly cxlianster, has been thought to take such an effect on the system, is to annihilate the renomous power. True, I remember a case in England, where two dogs were bitten by a mad dog, within five minutes of each other. One was a Pointer, owned by a great sports man of my acquaintance, who immediately drove twelve miles to the salt water, and there plunged his favorite almost to death. The other dog remained mmoticed and unattended to. In a few days after, the neglected animal rent raving mad and committed fearful ravages, whilst the Pointer never portrayed the most remote symptom of Hydrophobia, during the remaining years of his life. I have also seen various persons at Southampton, almost dured to death, to aroid the consequence of the bites 
of mad log:s, and this was eomsidered an ont sulficient safeguard. But 1 an rather slow at hasty inferences, especially on the sulpject of mad dogs. With regard to the fact of the Pointer mentioned, his system might not have been as susceptible of absorbing the virus as that of his mulucky neighbor, neither might he hare been as severely bitten, and as it is well known that all dogs will not be aflected by bites of ratid animals, the Pointer might have belonged to the class of non-absorbents. With regard to the peroons alluded to, they might have been bitten either by an imaginary mad dog, or by one whose nerrous system alone was under temporary derangement.

The bites of really mad animals differ widely in their poisoning powers, and in many cases I imagine the danger would he very trifling. the venom issuing from a really corrupt sys. tem must differ willely in rirulence from that produced by simple nervous excitement. I have often been bitten by dogs, laboring nnder temporary derangenent and mad to all in. tents and purposcs (if animals unconscious of their acts may lo termerl inane.) ant I certainIy have nerer lelt any fear and but little incon. 
renience from it. But the bite of a really rabid snimal, who has had the disease festering his whole frame, is at all times to be dreaded. Neither the Fits in Distemper, nor ordinary Fits should be mistaken for Hydropholin. 'They bear but little resemblance to it. Fits, in rabiel animals are preceded by different premonitory symptoms, and are generally the sequel of a train of incohorent, extraordinary and unreasonable performances. In all fits, howerer, the animal should be handled rery cautiously, as his unconsciousness may result in inflicting injury, where none was intended, and bites are at all times more or less poisonous. A person bitten by a mad dog should have the wounded parts immediately taken out by a skilful surgeon, and the sore should be afterwards thoroughly burnt out with lumar caustic. I would also recommend the application of a dozen lecclies to the neighboring parts, and a soft poultice to encourage the flow of blood to a limited extent, whilst a bandage be tied above the wound, to lessen the circulation, till the operation be terninated. Cooling aperient medicines cannot be amiss; the treatment howerer should be regulated through the adrice of a skilful practitioner. 
From what I hare seen and heard, I havo Eome little faith in salt water-ducking, and wonld certainly try it, as it would not be likely to do any injury. Do not wait for a Doctor to eut out the bite, if he be far off, and you have judgment enough to oplerate, without cutting an artery, or risking danger in the loss of blood. Time is every thing, amd if attended to carly, there is rery little fear of danger even from the most renomous bite. Many foolish people imagiue that if a liealthy dog bite a person and the animal should at any after time become rabid, that the individual may on that account become the sulject of Firdrophobia. This must be all monnshine. By the same method of reasoning, should the person with whom I associate in New York, die of the rellow ferer in New Orleans, I must also fall a rictim to it. How many faithful animals liare been sacrificed, through this nonsensical idea! Certainly it were better for a dog to suffer death, than that the nerves of anz human being should be continually agitated even by such peurile humdrum, yet it is high time that reasoning minds should aroid conclusions, where there is no connection between cause 


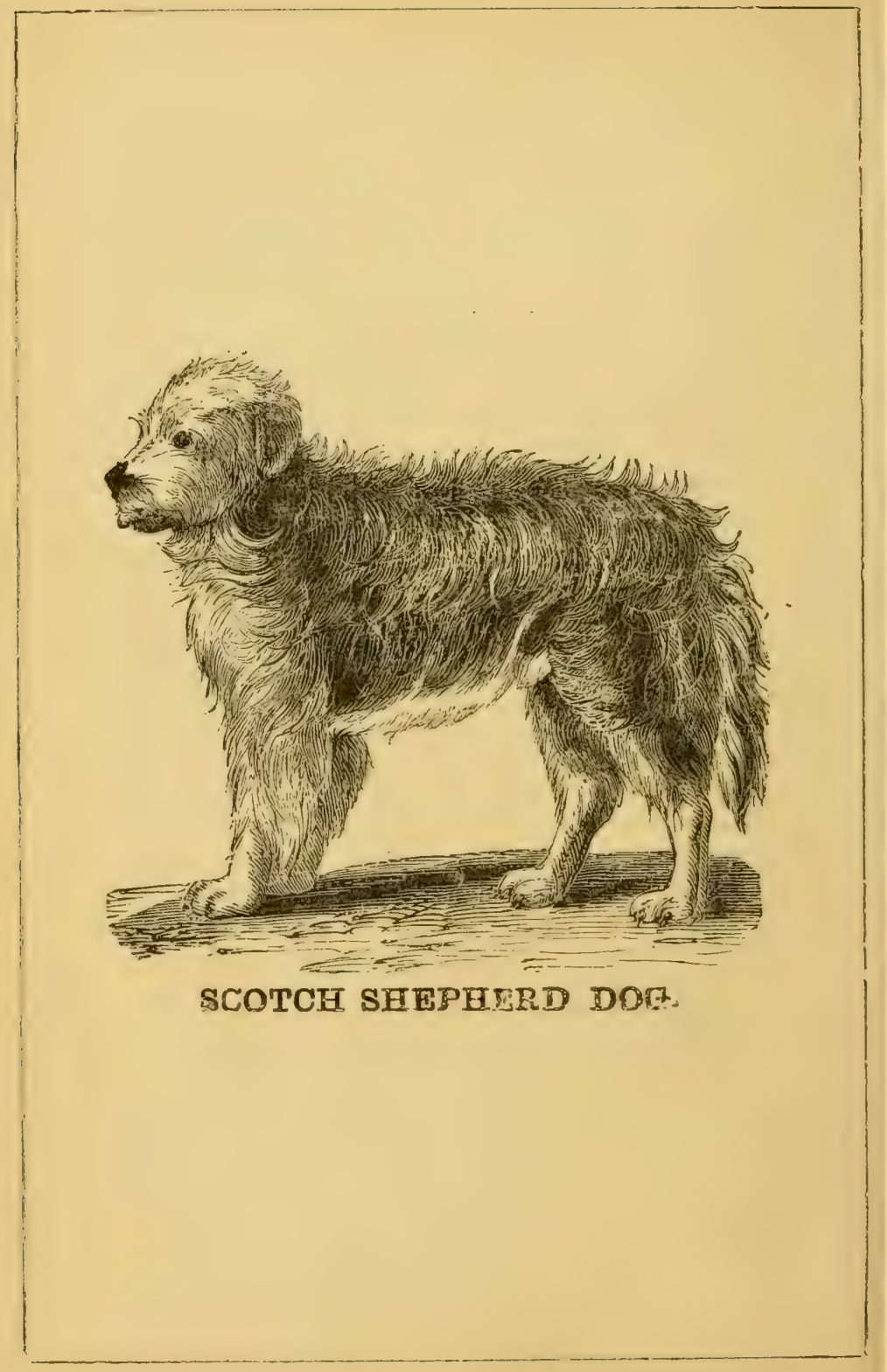




\section{SHEPHERD DOG.}

'T were rain, the Sheep-dog to depict in rerse, In doggerel rhyme, his merits to rehearse;

Known in all rerions, by a foreign name, Distinct his origin, his use the same.

Of varied caste, of different form and size, But ever honest, vigilant and wise; On Grampion hills, on Alps or Pyrenee, A matchless hound, of doubtful pedigree. Unlike his brothren, born to lounge at ease, Raised on the monntain, nurtured in the breeze, The truthful index of his master's eye, With him alone, content to live and die. On boundless plain or thickly crowded street, The faithful Colly, with his trnop we meet ; With speaking gesture and expression firm, Directs each movement, dictates erery turn. Inured to hardship, dreads nor cold nor storm, The sleepless sentinel, his flock to warn; Unseen, aloine, his midnight watch to keep, The bribeless guardian of the heipless sheep. Gentle his sway, yet stern his strict command, He guides unerringly his fleecy band;

No truant lamb evades his watchful eye, Nor dares his sovereign generalship defy. 
and effect. Hydropinobia signifies a dread of water; but it is no proof of canine madness that a dog should refuse to drink, neither is it a test of his sanity, should he drink to the full. In a certain stage of Irydrophohia, where the hearl is the most affecter, anytling glistening causes the unconscious animal to start and rary his course. When kept in the dark, or wirh little light, the rabid animal will generally kecp seciuded and still ; therefore in all cases of affection of the brain, he should be kept as much as possible from the light. Mad dogs when not exeited by glaring objects often drink freely to assuage the fever raging within, but in their flighty paroxysms they shum all dazzling oljects which flash on their disordered viaion.

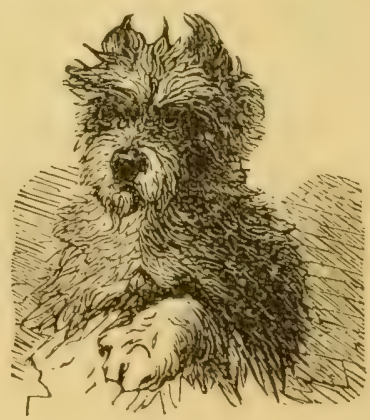




\section{COLDS, COUGHS, ASTHIIA, INFTAAS. MATION OF THE I.UNGS.}

Cotriss and Cough, when unconnected with any other complaints are seldom difficult to cure. Dogs are very liable to take cold, but we seldom notice it, except when we consider it either the forerumer or accompaniment of Distemper, or some serious affection of the lungrs. Indeed an ordinary cold, discernible only by a light watery oozing from the eyes or nose, seldom requires any medical treatment, should no other symptoms nresent themselves. An emetic of common salt, and the next day from half a teaspoon to half a table-spoonful of castor oil, repeated every two hours, till a good operation be cffected, keeping the animal in a sufficiently warm place, feeding him rather less than usual, (should he be inclined to fat or not 
habituated to exercise) will often cure a newlycuntracted cough or cold, without further rem. cilies. Should these fail, try the expressed juice of onions, boiled up with sugar; a teaspoonful or so to be given every three or four hours. Rubbing the throat and breast with spirits of 'Turpentine and oil in equal parts, or "Butler' 3 Mange Liniment," if you have any, will be of service. If the dog will drink fish oil of his own accord, he may have a teaspoor or tablespoonful two or three times a day. A few drops of paregoric, in ten times the quantity of water, administered occasionally, I have also fomd to afford relief. Distemper-cough, must be treated as a part of Distemper and other symptoms taken into consideration, but in any case, what I here recommend, cannot fail to be of good effect. Blisters may be resorted to, should other means prove unsuccessful, and should there be a continuance of ferer, the animal may be bled. I am no adrocate of blecding except in cases of incurable fits; blisters also are very troublesome, and I think may general. ly be aroided. Small and reperted doses of fish-oil tend greatly to relieve Cough or Cold, but should not be allowed to act too freely. 
A warm hed, light fare, freedom from damp or sikdten chills must however be particularly attended to.

Asthma is troublesome, and not so casily got rid of. It appears to settle more firmly on the constitution than either cough or cold, and is commonly the result of orer-feeding, of continued lack of exercise, of exposure to chilis, \&. c; therefore asthmatic quadrupeds should be liept on light diet, or if otherwise, should never be fed to the full, be well supplied with fresh water, and not be exposed to cold or wet. Gentle emetics often relieve for a season ; rub'bing the throat with a powerful liniment, not allowing the patient to get fat; gentle and regular exercise, all contribute to effect a cure. Milk, sweetened with molasses, is good for all complaints of the chest in dogs. Asthma is with diffieulty totally eradicated, but, by attending to the remedial means, the animal will generally suffer but little, except in cases of age, or a delilitated constitution. Blisters and bleeding are resorted to by those who undersiand the busincss, but their effects are seldom of lasting benefit. Hot baths and hearty ruh. bings are also very beneficial and the bowels should never lie constimated. 
Inflammation of tlie Lungs imparte to the animal a drowsy, sleepy appearance. He is little inclined to lie down, and is continually droop)ing his head, when sitting on hishaunches, is gen. crally very thirsty, with little appetite and hot breath. It is often an accompaniment to Distemper, when it is more fital than under any otlier circumstanees. When this disease is manifest, the diet should be rery light and nomrishing; the animal shonld be kept confortably warm. From ten to twenty grains of Nitre with from two to five grains of antimonial powder may be given morning and evening. A little croton-oil or blister-ointment may be rublied on the chest, or a bag of liot hops be placed between the fore legs for a few hours. But after all, care and attention are the most important, as any cold taken by an animal in this state is liable to be fatal. The foeces should be carefully noted, and Diarrhoca or Constipation immediately attended to. Rapid consumption will be the result of Inflammation of the Lungs, it the disease be not attended to in time. Warm baths, if the animal ean be afterwards thorough ly well rubbed and dried, will tend to invigo- 
rate and increase the circulation, but they should not be often repeated, or they may have the conirary ellect.

D.PFOSTERS

"LION"

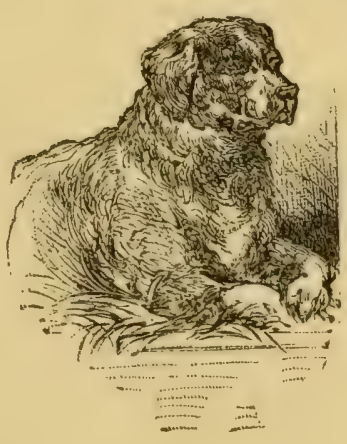




\section{WORHS}

Worus are very annoying to Dogs of all breeds andages, but arc seldom fital, after the teething-period. Puppies often come into the world, loaded with worms; if not,they generally begin to suffer from them, before they have deft off sucking. In puppies, worms nay be detected by an enlargenent and tightness of the bowels, a weakness in the eyes, coldness of the ears, a restless movement from place to place, particularly after a meal. Sometincs they produce great pain and cause the animal to otart up, continually uttering distressing cries, as though he were suddenly pricked with some pointed instrument. In dogs of maturer growth, the suffering does not appear to be very severe, but the annoyance generally reveals itself, by the animal dragging his hind parts along the ground, when the worms 
approach the rectum. He will grow lean without any apparent cause, will sometimes be ravenous and at other times refuse his food. Although I beliere few full-grown animals fall victims to worms, yet they are a constant source of annoyance and destroy both the com. fort and comeliness of the animal. As well nigh all dogs are more or less troubled with them, and as they may be destroyed withont resorting to dangerous medicines, the neces. sary remedics may be applied, where there is suspicion of their presence. In young puppies, sometimes a fow small doses of castor-oil will carry them off. Should this howerer. not suffice, other medicines must be resorted to. There are many excellent remedies for worms. The three following I consider all-sufficient: First, Cowage and Bitter Aloes. Sccond, finely powdered Glass, followed by a dose of Bitter Aloes the next morning. Steel-filings, followed by a dose of Alocs the next day. ' 'r'y three successive doses of the first, erery other morning on the animal fasting, if no improvement be visible, use the sccond in the same way, and if that does not give satisfac. tion, administer the third. Either of them may 


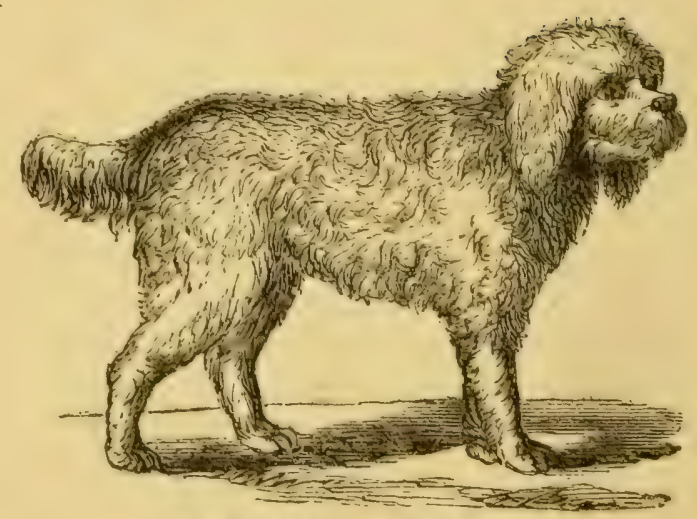

POODLE DOG. 


\section{POODLE DOG.}

White, black or brown, thick clothed in wooly hair,

A general favorite of the Ladies fair ;

'The showman's pet, of mountebanks the boast,

Snid to originate on Gallia's const.

Varies in weight, from sixty pounds to tiree,

Kind disposition, and from mulice free;

His dress (of course, ) rnust be in fashion work,

His noge, and hack, and feet all reatly shorn.

In conrage lacking, yet in fondness true;

His merity known, his vices hid to view;

Rendered effeminate, by female care,

By tender petting and from lack of air ;

Cuddled in laps, and nestled warm in led,

His pampered appetite on dainties fed ;

His race has dwindled; yet a hardy fow

Of vigornus growth, his sterner traits renew:

Frmous in wuter, vigilant on shore,

In Paris numerous, in Madrid a bore;

Found in all climates, known to every rank,

The silky Cuban and the curly Frank;

To music dances, vaults on head or toe,

Barks out the hour, or plays at Domino.

Such are his talents, that ere long, I guem

He'll beat Paul Morphy, into fits at Che 
he mixed up in fat ur suet, which the dog may be tempted to siallow, if the pill be wrapped in a picee of meat; if not, he may be easily made to take it. Rubbing the bowels with sprivits of turpentine is rery good, but it should be rubbed in, till thoroughly dry. Puppies with worms should be kept warm and comfort. able, ag when wormy they are wak and chilly. 'liere are a variety of these worms: thread. worns, tape-worms, wire worms, flat-worms. 'The wire-worm, I have found the most frouble. some and fatal; they are an inch or so long. about the size of small twine, very hard, and sharp pointed at both ends. They collect in knots, impeding the passage of the foeces, and will often, ii neglected, bore thromgh into the cavity of the bowels, after which the anima! will not long survive. I have opened many puppies, where the intestines have container nothing but worms, proving that what should have nourished the animal had been completely alsolbed by them. Cough is sometimes indicative of their presence, consequently may sometimes be reliered by the worm medicines. An emetic of common salt is a good beginning towards their destruction, as they often lodgo 
in the stomach and sometimes creep out at the month and even through the nose. If a dog docs not gain flesh on a reasonable allowance of food, he may be suzpected of worms and treated accordingly

Calomel, of courac is a great worn cure, but I never use it, because I consider the remedy worse than the disease.

\section{WORM DOSES.}

First.

1-2 ounce Stecl-filings, mixed in fat and made into twenty-lour pills, one more or less, to be given every morning, according to size $\circ f$ dog.

\section{Second.}

Teaspoonful Cowrge; 48 grains powdered Aloes; made into 12 pills, one more or less to be given every unorning.

Third.

A pinch, more or less of powdered Glasm, mxed in suet, each dose.

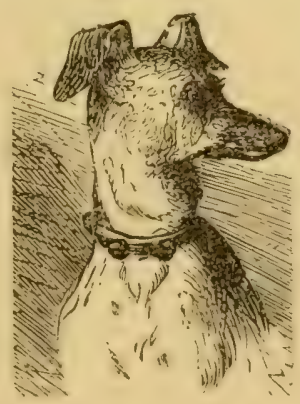




\section{RHEUMATISII, PALSY, PARALYSIS.}

DISEaSes of the nerres are not at all uncommon with dogs, and arc by no means the most easy of management, as they are often the focus of other maladies, which seem to revenge them. selves on the nervous system, and must not be considered mere local affections. They are not howerer sn difficult to cure, if taken to in time, before the muscles beeome too contracted to ndmit of restoration. Of course the longer the contraction has existed, the more distant the cure; therefore all nervous nflections should be taken in hand at the earliest stages.

Rheumatic affections in dogs, (as well in as the hrman race) are more effectually treated by simple preventives, than by any amount of Gamboge, Colocrnth, Calomel, \&.c. The fol- 
lowing causcs may suggest the most natural remcdies, viz: slecping in the damp, exposture to cold after violent exercise, sudden change from lieat to cold, lack of sufficient circulation after coming out of the water, gross fecting, combined with lack of exercise, \&c. No doubt the above are amply sufficient to produce any malady, incident to the canine system ; still, well uigh every dog is continually exposed to them, yet, how few comparatively are troubled with rheumatic complaints.

To the orer kindness or cruel treatment of the master, are to be attributed the majnrity of these ailments. The Sportsman hastily layz down his gun and hurries to his repast, whilst the poor dog, who has traveled three or four miles to his master's one, is left out of doors, chilled and unattended to, impatiently waiting at the door for a stray bone, or a few indigestible seraps, instearl of his having been heartily rubbed, decently fed and comfortably hediled. The house pet is hurried out from under the hot stove into the cold air, or is perhaps condemned to shiver awhile at the door, to atore for a milemeanor. The farorite New foundland is indulged to a bath, and tied up dripping to 
his kennel; the trusty guard-dog is allowed to bask all day by the fire, and is condemned to bark all night at the moon, to keep I imself warm. Continued constipation of the howels is often productire of various forms of muscular athection, by checking the regular action of the system, and prodncing an irregular and confined circulation. In fact, anything that tends to disorder the canine fabric may develop its results in a rheumatic form. I hope I may not be accused of Quackery, if $J$ an inclined to treat all diseases more or less alike; but one thing is certain, the stomach and digestive organs are the root of almost every maladr, and must be the first objects of our solicitude, in all plysical derangements. To many, the idea of giving an animal castor-oil for the Rhematism. or Sult for a broken leg, may appear decidedly preposterous. But with Rliemmatism we must also begin by purifring the system and attenring to the diet. The patient must be kept as much as possible from sudden ehanges, must be fed on light, yet nutritious fars, be provicied with a comfortable slecping place and not bo allowed to go out in wetweather. In the kennel to which he is chained, all chinks should 
be stopped, to exclute side-draughte, or ho should, (if not in the house), be more properly kept in the stable, or any convenient enclosure. Repeat rubhings, morning and evening of the parts affected with strong penetrating lini ments, * keeping the bowels gently ophen, and occasionally administering the anti-rheumatic compound :

Gamboge.

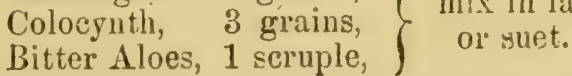

6 grains, $\{$ mix in fat

Divide into six pills, from half a one to two whole pills, to be given every evening, according to the size of the animal, and if necessary, a small dose of castor-oil, to be artministered every following morning. After the above amount of pills have been taken, (or six doses), the patient should be allowed to remain two days without medicine, unless it should be requisite, to stay a looseness or promote an eracuation. Setons and blisters may he resorted to, should milder treatment prove abortive, and when there is inflammetion, and there be strength enough to warrant blecuing, it may occasionally prove adrantageous.

"Butler's Mange Tiniment," is very effeacious. 
Warın baths are ofton productive of great benefit, if the animal he not permitted to take cold. The muscular affections produced by Distemper should be treated in a similar way. When the hind legs become weak or partially paralysed, a common pitch-plaster is excellent. The hair should be thoroughly shaved off, or it will not stick: the animal may be either muz. zled, or a little eil of 'Tar rubbed occasionally on the plaster will generally prevent him from bit. ing it. Strychnine has been used to advantage in desperate cases of Rlieumatism, Palsy and Paralysis, and I have known one instance. where a dog was cured by a dose intended to kill him. With all this, if it be seed at all, it should be in very minute aoses and under the advice of a medical man, and then only ais a forlorn hope.

To Calomel, we are indebted for many casez of incurable Rheumatism; therefore avoid it, us much as possible, except in cases, where the sufferer is free from cxposure, or where other remedics have failed; even then I would only wive about a third of the ordinary veterinary dose, combined with a sufficicint quantity of Rhubarb to correct it, and Aloes to carry it off. Is in other disorlers, strengthening 
medicines may be necessary, such as Peruvian Bark or Gentian Root mixed with ground Allspice. For delicate dogs a covering may be made to go over the loins, where there is a tendency to werkness, which should be put on enly, when he is taken out.

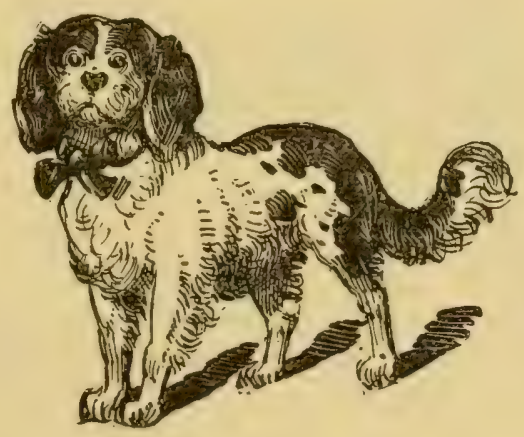




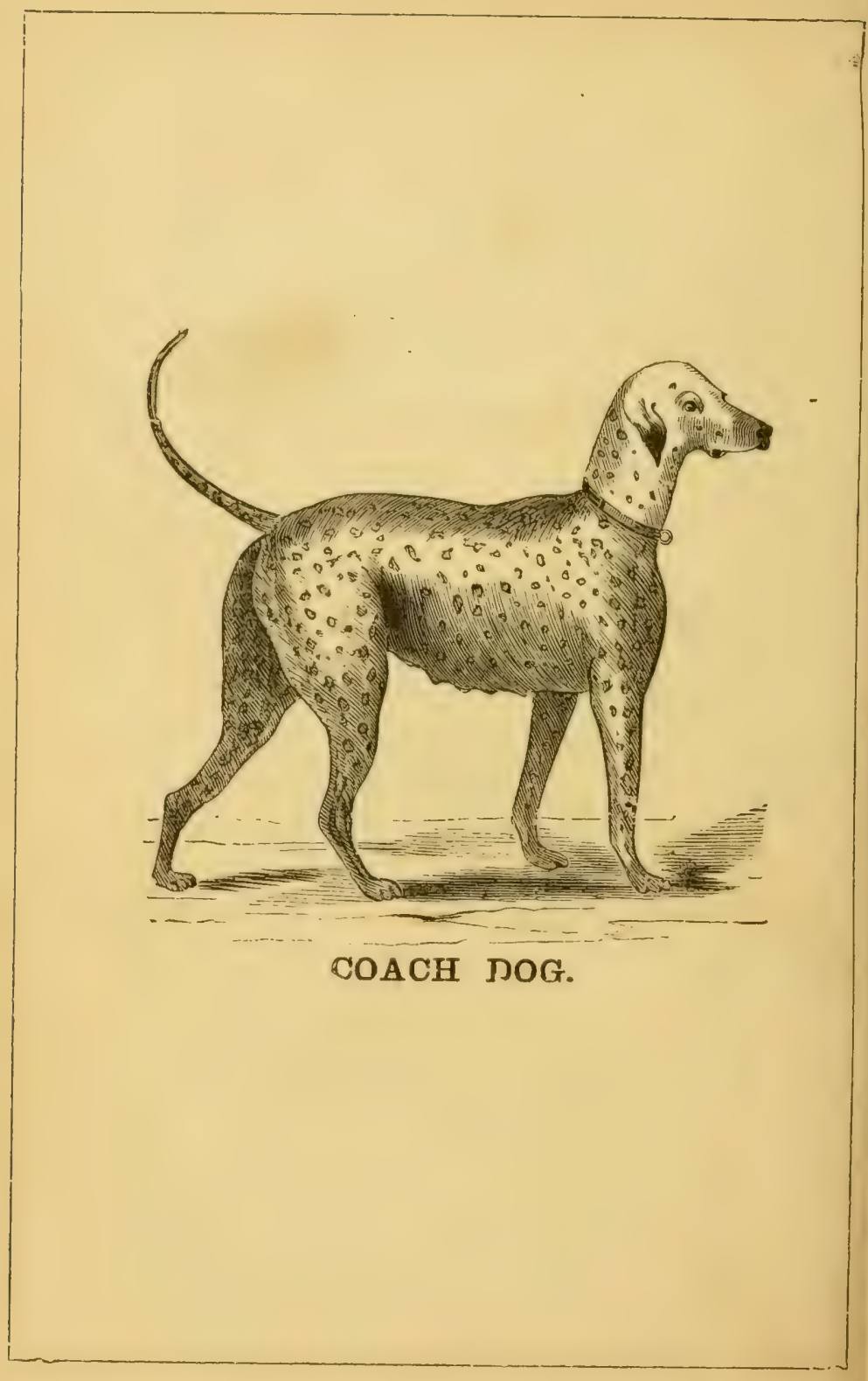




\section{COACII DOG.}

Denmark ('t is said,) was once the faror'd State. Where Coach dogrs first were wont to congre. gate ;

Now graces every canine catalogue,

'The well known spotted coach, or earriage Deg. Of growth genteel, of Pointer ferrn and weight, Is highly prized by fancy men of late;

But erery spot must be distinct and clear, Of equal size, and free from blot or smear ; His form erect, with tapering tail and tine Smonth close-set hair, and perfect erery line; Thin drooping ear, clear-chanber'd glassy eye, Lest either lacking, should his race belie. From mean as occiates, scornfully abstains, Nor mongrel cur his confirlence obtains ; The horse his friend, the stable lis delight, Follows by day, and beds with him at night ; Onward they travel up the hill of life, Unenvious, sociable, devoid of strife ; Attachment strange, yet true, 'twixt horse and hound ;

For 'mongst them all, was ne'er a traitor found, With joyous glance, salutes his friend at dawa. And checrs lim in his weary journey on; In days of languor, or whato'er betide, His faithful guardian, sleepless by side. 


\section{DISEASES OF THE EYF}

TuE eye of the Dog is subject to a rariety of morbid afections, the majority of which do not originate in the eye itself, but in a disordered state of the secretions; therefore, the general health has to be taken into consideration whilst our efforts are alike directed to the locaiity. The eye may be inflamed from ferer within, may portray the paleness of general debility; may display its sympathy with disease fastened on the whole system, or may be deranged sim ply from outward causes; yet, in nearly all cases, the foundation of its cure must be in righting the main-spring. Any disordered action of the secretions will generally be visible in the appearance of the eye. Unless the disease be purely local, no powerful wash or lotion whatever, should be used to the eye of the Dog. 
Gently washing with lukewarm milk and water, keeping it perfectly free from mucus, rubbing in fresh lard, butter or goose grease around the neighboring parts: add to this light fare, ligh aperients aud little sunshine, and rou will do more to abate inflammatory action, than by any powerful application.

The dull blueish film, often formed on the cye of the distempered animal, requires no application whaterer, except that the eje be kept perfectly clcan and lightly greased. It generally clears away, it the animal recovers; whether or not, I consider all local attempts at for cing a cure are worse than useless. The film or coating that makes its appearance on the eye of a healthy animal should not be allowed to thicken or increase, or it may erentually terminate in cataract or blindness. White sugar, fincly pulrerized and blown into the eye through a quill, every morning, will at tl:c outset generally effect a cure. A little butter dissolved in the corner of the eye is often of great serriee. When the foregroing are unsuccessful, finely powdered alum, in minute quantities blown into the eyc may have the desired effect. Should this fail, it may be washed with a weak 
solvicion of sugar of lead, or sulphate of zinc, otherwise a solution of nitrate of silver, one grain to a wine-glass of water with a tea-spoonful of brandy in it. Only a drop or two of this must be dropped in the eye morning and evening. Common wounds, bruises, swellings and such like in the region of the eye, are speed. ily cured by "Butler's Mange Liniment;" but this shotild never be dropped into the eye. Where this is not to be had, a compound of Brandy, olive oil, laudanum and turpentine may be gently rubbed aromud but must not be allowed to enter the eye. Where nothing else can be found, goose-grease lard or butter will be of gleat service. Cataract in the eye of s, dog is seldom eured, if firmly established, as it that state, ordinary applications are of little service, and few understand the operation of remoring it; nerertheles, if the patient be of sufficient value, an oculist might operate ou it with suecess, as the animal may be safely and securely bound for the operation.

Running eyes are commonly caused by high fecding, constant colds, lack of general exercise, damp beds, \&c. Sometimes they are the result of Iistemper and often hereditary, in delicate 
and higl-bred pets. Keeping the eye clean, restricting the animal to moderate fare, allow ing him regular exercise, kecping him from sudden chills, forbidding him the hot fire or burning sun are among the principal preven. tives. 'This running appears to be a natural leak of the system, and unless the health be attended to: no local application will be availing. I am by profession neither Surgeon nor Oculist, therefore I shall not enlarge on the different affections of the eye, nor infringe on its anatomical technicalities, ss I am not writing a medical work, but propose simply to give the results of my own personal experience. For any serions operation on the eye, I would refer my rearlers to some competent su'geon or oculist, adrising them by no means to risk it themselres. If requisite, soft lukewarm poultices of bread and water, bread and milk, flaxseed, \&c. may be applied with advantage, where inflammation arises from any canse whatever: as to putting on and kecping them in place, it must be left to the best judgment of the owner of the patient. 'To keep the eye in a healthy state, especially in animals of high breed and delicate constitutions. ererrthing gross in diet 


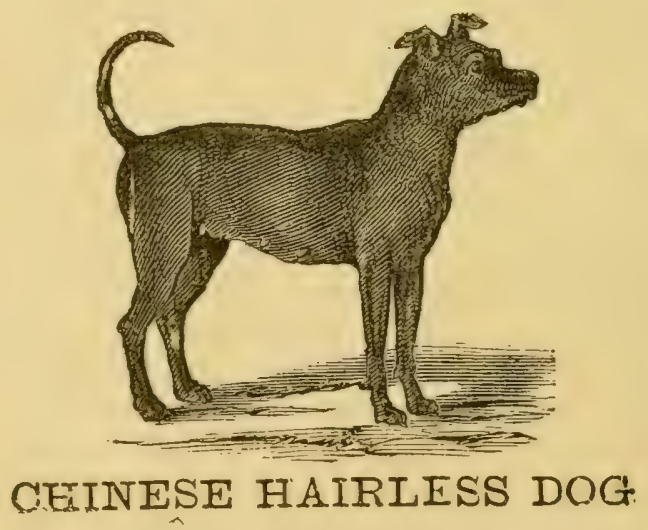




\section{CHINESE HAIRLESS DOG.}

Of goodly form, oft' portly, plump and round; In every clime occasionally is found; Of high repute, in that celestial sphere, Where dogs are dainties and fat pork is dear. Called Turkish, South American, Chinese; Tho' fitted best, Jolın Chinaman to please ; For tastes refined and Epicures decreed, Good roasted, boiled, fried, stewed or fricassced; Guards well the house, and keeps the thief at bay ;

Does useful crrands, for the folks by day; Barks at their pigtails, licks their stunted feet, And grubs lis hasty living in the strcet; But woe betide him, when for cooking fit; It bodes him not, his merit or his wit; Doomed to the oven, or frying-pan his lot, His grave the stewpan, or his tomb the pot. Doubitless well known, in ancient days was he, Ages before the Anno Domini ; They say Confucius fared on Canine stew, And sent Pythagoras a chop or two. Be't as it may, yet dare not raise a laugh, Such menial hounds inspire no epitaph ; They crave for food, that they nas fat tho faster,

And die a sacrifice to feed thetr master. 
should be forbidden, and constipation carefully aroided. Although in many cases, weakness and running of the eres are incurable, the fore going preventires will be far more effective than all that medical treatment could ensure. Slecping in a damp place is highly farorable to the production of orerflowing humors of the eye, and no cure can be expected, where an animal given to weeping, is thus exposed. Blecding and blistering are sometimes resorted to, for redness and other inflammatory syimp. toms of the eye, but as few of the unprofession. al understand these operations, I shall not re. commend them here. Some dogs hare naturally a ferocious redness abont the ball or in the corner of the eye. When this is constintional, there are little hopes of a cure. In cascs of continued inflammation of the eyc, a red hot iron, about the size of a common lead pencil, may be presecd through the skin, at the loack of the head, (should other remedies fitil) and the w. sued may be kept open, unnel st marked im. provement or a cure be erfected. 


\section{DISEASES OF THE EA?.}

Drsease of the ear is mostly confined to over fed animals. Wandering mongrels ard dog's boarding at their own expense are not so liable to outbursts of gross humors. Heary-coated dogs are of tener attacked with it, thin the less thickly-coated. Regular exercise, cleanliness and simple diet are the most important preventives. The ear is subject to disease in a variety of forms; common inflammation, sores, boils, ulcers, canker, polypus, dc. Any ailment of the ear may generally be discovered by the animal's shaking his head and rubbing it with his paw. Should there be any thick or matted hair inside the ear, it should be cleared out as gently as possible, with a pair of tweczers or the thumb and finger. Whatever be the form of the sore, the ear should first undergo a thor. 
cugh cleansing twice a lay with Castile soap and lukewarm water for two or three days, withrout any other application. After every washing, the ear should be rubbel perfectly dry. After this, a weak solution of alum may be used twice a day, gradually increasing its strength for three or four days in succession; after which rub in "Butler's Mange Liuiment," which never fails to heal up any kind of wound or sore. If this howerer be not at hand, make an enbrocation, composed of one-fourth spirits of turpentine, one-fourth oil of tar, and a lalf of olive oil well mixed together, which. shonld be applied every day. If the ear should be very thick and nuch inflamed, a soft poultice may be applied, either of flaxseed meal, bread, or Indian meal made with strong green tea. But, if we can do without poultices; so much the better, as they are troublesome things, and most animals dislike bandaging. It may occasionally be adrisable to lance a sore, should it continue to inflame, after other applications have proved unarailing, but should it form a natural head, I have found it better to allow it to take its course and burst of its own accord. With solid tumors, the case is different, if they fail 
to diminish from the use of ordinary means, the only remely is to have them carefully cut ont by a skillful practioner. Whaterer be used as a wash for the ear, it should be bloodwarm, both on accomt of its being more suitable to the sole or infiammation, lut far less shocking to the auimal. A weak solution of extract of lead, with one-tenth brandy may be used as a wash, and if used bloodwarm, may be poured into the ear, if the part affected camnot. be reached with a sponge. For olistinate discases of the car, that yieli neither to a purification of the system, nor to ordinary outward applicatious, the base of the ear may be bored with a red-liot iron, about the size of a common lead pencil and the wound kejot open till the discase is staycd. I lare found this to be of grent benclit ; it acts as a counter-irritation and thus relieves the affected part. The edges of the cars are sulject to a scably mangy appearance, which destroys the growth of the hair. and sometimes gralually inflames the whole flap. "But'er's Mange Liniment" will speedily cure this. If it caunot be had, rub the ear every two days with merourial ointment, and every other day it should be thoroughly cleansed and 
waslicl off with alcohol, as strong as the ani. mal can hear it. If a riolent discharge of the ear should not be checked by the forcgoing remedies, the ulcer may be burnt out with caustic. Often a putrid odor will issue from the diseased enr. thongh this cannot continue long, when it is kept thoronghy elean. A solution of chloride of lime, very weak, will act as a purificr. This slould be used with the sponge, if the diseased parts can be reached. In curing diseases of the car, as with all other ailments, the most important thing is to attend to the general health of the patient, as otherwise the disease may lie only driven from one locality, to be forced out of another. It may be often necessary to muzzle the animal, on ap. plying the wash, poultice, seton, \&e. ; lie may easily be kept steady and harmless, and should on no accomnt be neglected. on account of his aversion to handling, but as little roughness as possible should he resorted to. 'Thorns shonld he carcfully extracted fiom the ear, before any inflammation sets in. as they then become more difficult to detect and more painful to extract. I recommend as a prerentive against sore cars, that they be kept perfectly clean by a rerular 
systematic cleansing with soap and water. I re ally believe filth to be the gre andwork of half the discases of the ear, as, however clean other parts of the body may be, the ear is generally left in a dirty condition. Few even, who wash their little pets a : er think of thoroughly cleans. ing the inside of the ear.

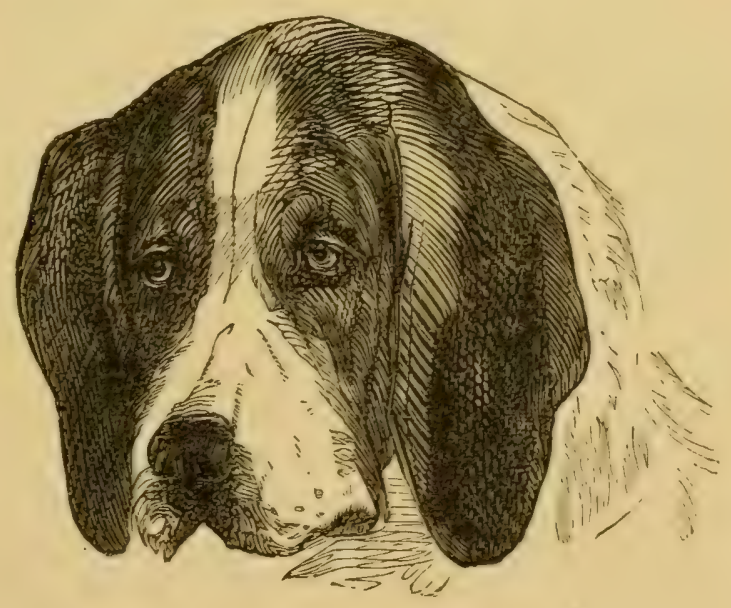




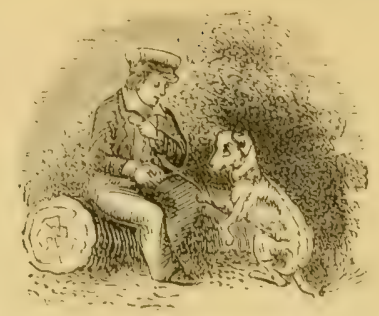

\section{SPRAINS. NISLOCATIUNS, FRACTUKFS, WOUNDS, SWELLINGS IN THE NECK ANI) 'THROAT'}

Srrans.-frowing doges, in particular, from their will reckless gambols are very apt to sprain their joints. I have had a number of cases, where a puppy has become lame for a considerable time, yet the exact nature of the spratin could not be defined, as nothing could be felt out of place. I have therelore been led to supprose that some of the small tendons uniting the joint were over-strained. If not allended to carly, a constant lameness may be he result. 'The rubbing in of a strong liniment such as "Butler's Mange Liniment," or any other powerful counter-irritant, bathing the part often with cold water, enforeing on the euimal perfect rest, alministering cooling med. 
reine should there be any sign of inflammation are about the best means of effecting a res toration.

Drsiocation, or the displacement of a joint, shonki be immediately somght for, shomld there be the least suspicion of its cxistence; as a joint remaining unset for a time, not only becomes rlificult to re-set, lut ser’ions inflammation may arise, from its being neglected, and the cure lie remleren excecelingly diffeult. By carefully fecling for the joint and moving the limb gently backwards and forwards, a dislocaltion may he easily detecter, and little skill will he reguired in settine; but don't pull too harel at once; let your effurts be graduated, according to nccessity, or you may straiu the nerves in righting the bones. After all is made right, the same means may be used as those recommended for Sprains.

Froctures demand more skill in their treatment, as the lonnes require to be set in their place, and small pieces may have sometimes to he extratel. The splinters (two thin pieces of wood, whalchone or cardhoard) should be care. fully put on and bandared over with a strip of calico, muler an inch in breadth, but sereat cau- 


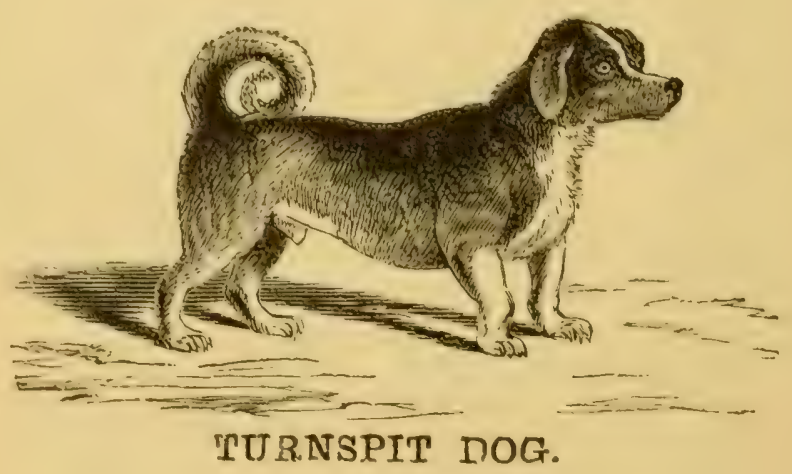




\section{TURNSPIT DOG.}

Yellow or brown, with muzzle nften black, Low bandy legs, and disproportioned back ; Eye of intelligence. ear rather small, Nose quite extensive, teeth, the hest of all ; Short coat, stout builr, inclerant in form, Problen unsolved, where 'Turnspit first was born ;

His home the kitchen, 'prenticed to the cook, He notes her movements, scansher erery look. When fat and lazy, and for work unfit: Is oft' incor., when ealled to turn the spit; Hides in the garret, or would fain be laine, So dir ner's late, and Bandy gets the hlame. J)efends his post beside the kitchen fire; Nor stranger dare provoke his latent ire; Jisplays lis irorics, and with angry tone, Growls out menacingly, "let me alone." Unlike his compecrs, rever made a pet, Confined at home, and at his duties set, His worhing time p'raps three scant hours is day,

From them, unguarded, slyly steals away. Although his master often may you greet, Ashamed t' acknowledtere Bandy in the street: Alone perchance you'll find him on the jog. The awkward, crooklegred, lireside kitchen dog. 
tion must be used, not to tighthen them ton much, which would produce inflammation; yet they must at the same time he made fast enough, to prevent them slipping, or causing a disunion of the bones. It should not be taken off until the fracture be thoroughly and stontly knit, unless there should he appearance of inflammation. The dog should be kept at rest, until sufficiently recorered, and thea he should for a season be led on the chain, and not be allowed to romp at discretion. The fracture may be afterwark dity strengthened by penetrating liniments, and cold water applications. Fractures, other than of the limbs, will require skilful treatment, or must be left to work their own cure. Dogrs are wonderful creatures and really recover the most desperate poundings, withut medical adrice or surgical aid; there. fore. what you don't understand, you had better let alone.

Wounis arc seldom difficult of curc, and will heal up without our assistance, unless the system be disordered; in which case. coolingr medicines may be necessary to pmrify the bleod and facilitate the efforts of Nature. If a wound be linge, it should be sewed up with 
thread; by uniting the parts, it will lieal the soonce. Uil of 'Tar and olive-oil in equal parts will both cleasse and heal a wound. "Butler's Arange Liniment" is also a specly cure. Any kind of grease is soothing, but shonlit lave no salt in it, unless the wound be foul, in which case it may be washed occasionally with weak alum water, which is very clcansing and prevents the formation of proud flest. For mange sores, use "Butler's liniment." In any case, keep the animal cool and quiet; provide him with light food, fresh water and comlortable lodgings.

SWeltivgs IN THE NeCK AND THROAT will sometimes make their appearance, so inexpectei and suddenly, that we are at a loss to account for their origin. With external swetlings, I have seldom found any difficulty. Spipits of turpentine, oil of 'Tar and olive-oil in equal parts form an excellent liniment, which should be well rubhed in morning and erening. Should lancing be necesary, it should be done by some one that understands it, and this not till the inflammation has pretty well reached its height. Conling inedicines may he neces. sary to purge the system aud lessen the tenden- 
cy to putrefietion in the humors. Any strong liniment will be of serviee, and if none can be had, bathing the part in colil water may effect a cure, or if you will tic the animal up in a cool place, feed him light, give him a regular supply of fres! water and a little cooling medicine, a cure will generally be effected. Nature, with a little encouracement knows well how to reject impurities, that have been fored upon her. Should the swelling arise throngh any foreign ohject having poisoned the part. every eftort should he made to extract it: if this cannot be efferted. linsechlmeal with a litthe oil of 'Tur may he used as a proultiee, or a pitch-plaster with a hole in the centre be placed orex the part. When the swelling is inside the mouth or in the throat, it lecomes more serious and difficult of management, as when there is irritation or pain insicle the mouth, a dog gets restless and is sometimes diffieult to handle, witliont endangering one's fingers. Blisters and liniments may, howerer, be applied to the neighboring parts. Objects stuck in the throat should be pushed low with the first suitable thing that ma! present itself, os, if the animal be choling there is no time to 
be lost. A pliable twing a teaspon, or tableapoon will answer the purjuse; a piece of whalelone will do better. For any settled ailment of the throat, an occisional emetic of common salt will generally greatly relieve the suffering, by cleansing the diseased part, rirding it of purulent matter and perlapes burst. ing the sore. But with all swollings in the in. terior of the mouth and neck, I recommend the animal's being safoly chained, as he will sometimes lucones exceerlinely irritalle; so much so, as not to prorluce IIydropholia, but such a nervons timidity (I presume) that he dreads the approach of any one, and is willing to attark anything, in alporent selfedefence. I have seeti several cases of this kind, where my arl. rice has been luckily attended to, thus avoil. in? any amount of alarm, if not of recided dancerer. For all dienrders of the neck, throat, \&c., the bowels slinuld be kept in a proper state, the riet should be light, and the dong shoud he kept as quiet as posilile. When he is unable to eat solid ford. hie shonld loe supulied with soup, milk, \&ic. A tea spron of olire-oil, now ansl then will afford the throat some relief, as well as inpart nourishment to the animal. 


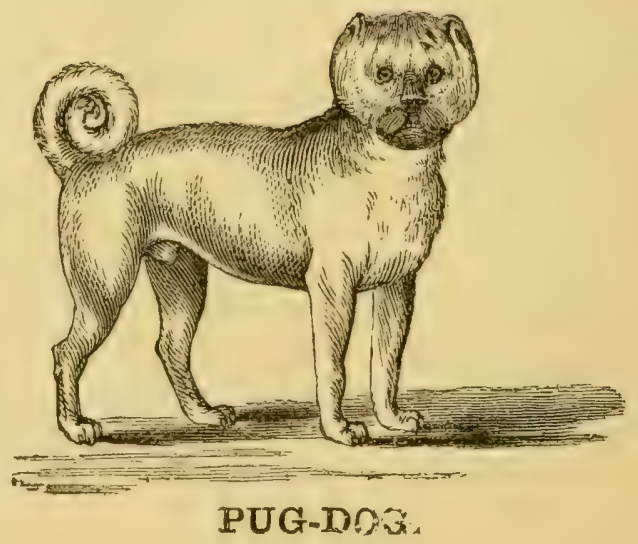




\section{PUG-DOG.}

B!ack nose, with body brown and curly tail, Uld fashion Pug! Come tell us whence you a hail!

Thy race declines, thy former history fades, Tho' once the idol of forlorn old maids.

And t' were as well ; thy compact form displayg Far nobler traits than speak thy meaner ways; Pugnacious front, round head and daring eye, Thy bumps renowned Phrenologists defy. With noisy yelp, both friend and foe he hails, But triskly ilies, when ought of pluck assails; Growls at the moon, and starts at every crack, And at the sound of danger, turns his back. Doubtful his pedigree, his origin obtuse, "Tis clear he's more for ornament than use ; Yet:-till, with all his faults, there surely is Something unique about his matchless phiz. He must have thought how men could be such brutes,

To pluck his hearing organs by the roots;

A fancy notion, say they, of the man,

A IIollander, who brought him from Japan. Companion of the gentler sex alone,

"Tis thought that hence he might have timid grown ;

If true it be that " manners make the man,"

What makes the Pug ? let him decide who can. 


\section{SORE FLE'P.}

Huxtige dogsespecially are frequent!y sulyee to sore feet. 'The causes are: traveling far on the hot ground or on a gravelly soil, orer work, frost. mange cruptions, improper fecting. \&e., but the most prominent of all, is lack of regular exereise. Any luman being, macenstonicel either to riding or walling, will feel the sore effeets of a prolonged pedestrian or equestrian excreise. 'Therefore the greatest preventive against sore feet is regular daily exereise. My cxprerience in this is contirmed by multitudes of professional Sprortsmen.

The remedies are rarions. Sometimes simply washing the feet with alum water will eflect a spredy cure. Whaterer he the applieation, the feet must first be thoroughly eleansed, and be well furstected ayainst dnst, dirt, other- 
wise the cure must naturally be delayed. or the evil increased. A few days rest on clean straw and the application of fiests lard, two or three times a day may be sufficient, strould the feet he simply cracked with the heat. If the hair be falling off and enptions apprear, "Butler's Mange Liniment" will ctlect a curc. Jf it proced from a gencral groseness througl the whole system, the diet should be light, and grsutle aperient medicines will he of service. A flused poultice is excellent, where there is infammation. 'The fect should be carcefully washed with Castile soap and luke-warn water, betore every application and the pronlice should not be left on till dry, nor too often repeated, which might cause an enlargement of the wounds. The diet should he light, the animal should be allowed resy little exercise, and the gencral state of his liealth shruld be atterisled to. In dry parched weather, leathern bonts are a great protection to the feet, when there is any tendency to soreness. The dog must be haljituated to them, before lie is taken out, or he will find them troo great an annoyance, to permit him to attend to his dutics. Should the to nails grow inconven. 
icntly long, they had better be filed off; as they are ant to injure the licet, and prove an annoyance to the auimal.

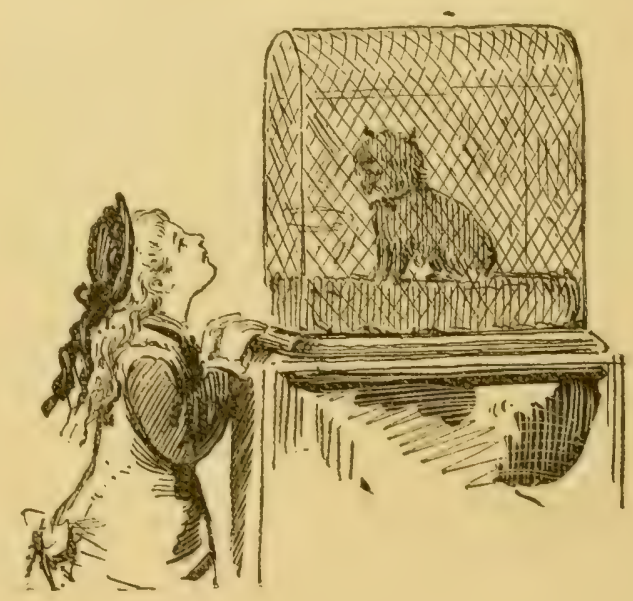




\section{REMARKS ON ILLUSTRATIORS.}

Is presenting to the public what I believe to be faitlful representations of sumiry varicties of the Canine Specirs, I camot dare presume, that even the linoving ones will pronounce them all to reflect the image of unariulterated stock; first, becanse there does exist a great varicty of appearance, even in animals of pure and un. suspected blood; sccondly, our ideas of purity seldom exactly agree, owing to a peculiarity of stamp, preferred ly different fancy-breeders. Nevertheless, the animals have been selected by the Artist and mycelf, as the fairest speciinens, which our united judgments could dictate, as the most likely to convey the idea or distinet Pedigree, to the total exclusion of Mon grelism. I can simply rouch for their being true to the life, and trust that in charity, all de 
268 IREMARKS ON ILLUSTRATIONS.

fects may be antributer to the Dog's, rather than to the Artist or inyself.

Bruvo.-The illustration represents a well trained animal, in possession of the Author. 'I'he breed owes its origin to the St. Bermard, Newfoumdland and Alprine Shepherd-dow, although I commonly term them the St. Bernared Newfoundland. The sire, old Brumo, was purchased of me by B. M. Whitlock, E:q., of New York city, by whom he is highly estecmed and treated like an educated dog should be. 'This breed is everything that can be desired, being equal in size. and (I think) superior to all others, in beauty, intelligence, activity and vigilance. Height from 30 to 34 inches; weight from 130 to $200 \mathrm{lbs}$.

St. Bernard.-These dogs take their name from a mountain of the Alps, celebrated for a Convent inhabited by Monks, who breed and train them for the purpose of carryiug provis-

- ions to travellers, who may chance to lose their way in the deep and ofttimes impassahle snows. licy are from 29 to 34 inches in height; length from 61.2 to 7 feet, and when in gond condition will weigh as high as 200 lis. Their color is senerally buff or light red, the muzzle dark 


\section{RENARLS ON ILLUSTRATIONS. 269}

They are not presumed to be an origiunl breed but appear rathes to be a mixture of Spanist Mastiff and Bloodhound.

The Neweound Laxd is perhaps better known than the majority of breeds, being a general furorite. 'There are rarious stamps of New. foundlands, varying both in shape, growth and hair, according to the latitude of their nativity. The pure should be entirely black. They may be greatly imvroved by a judicions cross, after which tne color's of course are inclined to vary. On the Sea coast, he will subsist entire. ly on raw fish, and spends the greater part of his time in the water.

St. Bernard Newfoundland, is a cross between the St. Bernard and Newfoundland. He is a fine large, handsome, majestic and respectable looking dog, remarkable in beauty, sagacity and intelligence. His height is from 30 to $3 t$ inches, and I have had them weigh orer 200 lbs. He appears to inherit the virtues of both Sire and I)am, without any of their failings. Their colors vary from jet-black down to light fiawn-color.

Broodhouxd is the largest of the Hound species, but his appearance and courage indi- 
cate a tinge of Mastiff or Bull-dog. The pure old fashion breed is nearly extinet, and various stamps of Dogs are now termed Bloodhounds. ITe is not naturally such a ferocious amimal as lis nane might imply, but as he is trained to follnw the scent of human blood, he is deservedly dreaded by those, who are macquainted with him. He is principally renowned for catching Negroes, and when put on the scent of a man will follow it as true as the IIarrier does the Hare.

Scored Deer-mound appears to have orienill. ated in an amalgamation of Scotch Terrier and Greyhound. He is powerful, flect and comra. geous, and measures sometimes orer 30 inches in height. His hair is rough, and generally of a yellowish color. In him are combined the nelre of the Foxhound, with the fleetness of the Greylound. These dogs are rare, and fetch occasionally enormons prices, as few ercr own them but the Nobility and Gentry, who hold almost exclusire possession of the pure Stock.

Stag houxd, Chaxtereer.-A true English Staghound of the stauncli old breed; now all but extinct. This race of homis is very rare, even in England; the fast going moderu Fox. 
hourd, (bred chiefly for speed) haring banished the old breed from the kenuels. In the days when this Hound was used, the hunter was a strong complact horse, not fast, but a good fencer, agrecing in every respect with the sturdy, cleep-mouthed pack, he was called upon to follow. At present, the fashion is altered, and higher bred animals are required to keep pace with the pack before him.

Foxnound, Jolly boy.-This extraordinary IItound was bred in Yatterson, N. J., and comes from a race of black and tan Foxhounds alike celebrated for their speed and mettle. His real time is not known, but from his astonishing performances, it is fair to presume he may outlast anything, than can be brought into com. petition with him. A glance at hisslortround barrel, his monstrous shoulder, the broad and ample quarters, the fire of his eye, and the res. olute dare-devil expression of his face will be a sufficient guide, as to what the tout ensemble of a good lasting Foxhound should be made of. Jis owner elallenges him, without hesitation, against any Hound, which England or the United States can produce, to run drag, Fox or Deer. No fence lias been found too high for 


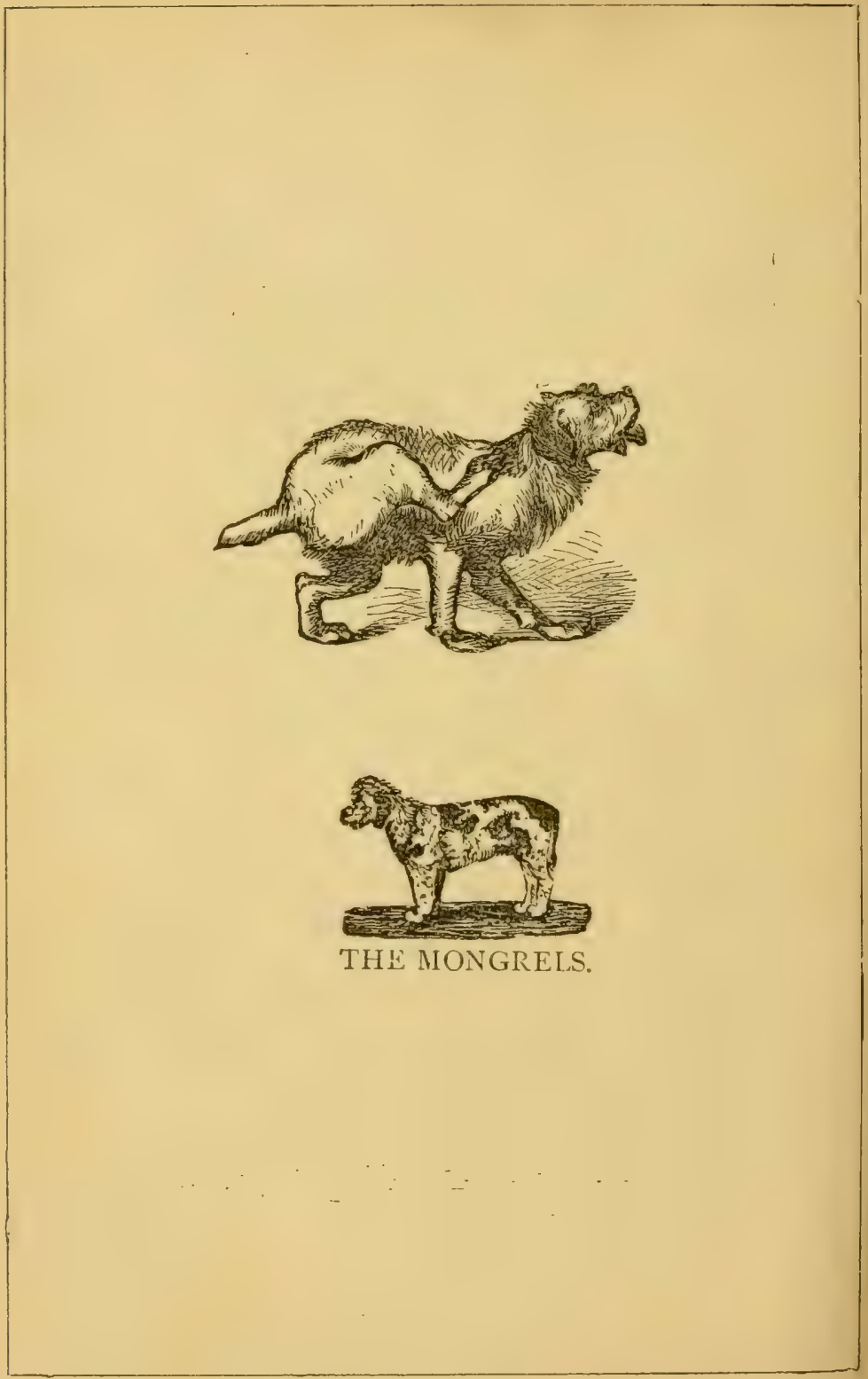




\section{MONGREL.}

Call lim Nerfoundland, Turnspit, Pointer, Skye!

Crooked leg, long back, snub nose and bleary cyce :

With Setter head, Hound-car and Terrier-tail!

Whilst Pug and Poodle on the whole prevail!

A public nuisance, and the neighthor's pest;

His home the gutter, and the street his rest;

Nor road, nor path, nor byeway, but reveals

Some sucaking Yipyap, skulking at one's heels.

Incessant yelps, cries thief by niglit and day,

Rut thicf in sight, the Mongrel shirks away;

Mocks the faint echo of each canine tone,

Yet flies impromptu, frightened at his own.

'I'o title such a despicable brute,

Demands a sobriquet, his race to suit;

By dogdom doomed, of wit and merit stript,

Outcast, pleb: ian, Mongrel, nondescript,

But may exclaim some educated Cur :

"Why h'ast our race, by such contemptuous slur?

Pause, pity, ponder thy polluted page,

Rude, raving rhymist, rest thy ranting rage;

A mong us rare, the Mountebank or Scholar, And varer yet the Cur, that's worth a Dollar ; Yet treat is well, and train us like a Setter, A Ilungrel's word for 't, we'd ba ten times better." 
him, no run too long, and no IJound sufficiently swift to show him the rond.

Hamine, "Barman."-An honest representation of an honest hunter. Small, light made and possesing wonderful power of nose, she is able to keep her place in the field, with the best of Foxhounds; often performing miracles in eold weather, when the leading hounds are at fiult. Barmaid was never known to orerrun her game. Our illustration gives her action, wlen rmming at full cry, and will be recognized by many, who have witnessed her performances.

BeAfie is the smallest of the Hornd Speeies. They were formerly hunted in packs, but since the introduction of faster stock, their use has been diseontinued. Ite has superior scent and great enduranee, and is the best dog in existence for rabbit-hunting, on account of his slow pace and diminutive size.

Greynound (English) is perhaps the most elegant of all the hunting breeds. Mis spred is supposed to equal that of the fastest race-horse. If thorough bred, he runs wholly by sight, which is superior to that of any other dog. In a coursing match, should he attempt to make 
use of his scenting powers, he would be ruled off the course, as foul-bred. They require great care and attention in lot climates, as on account of the thinness of their pelts, they are very susceptible of atmospheric changes.

Greynound, Italian, is rery similar to the Englisli, but much smaller and too flimsy and delicate, to be of any service in the ficld, though certainly the most graceful of parlor-pets. Some, when full grown will not execed 6 or 8 lbs. in weight.

Ponser is much similar to the Selter, in his natural instincts, and equally varies in size and color. ITe is more suitable than the latter for Sporting in hot weatlier, on account of his thimmer envering. Several countries boast of their celebrated breeds of Pointers. My own opinion is that they are equally good in all bat itudes, when they are well trained.

SETter when well bred is a very clegant dog, and deservedly esteemed for his game-limuting propensities. His color, size and appearance vary (like the Pointer) according to ilue taste and judgment of the breeder, but as three or four shades often appear in the same litter, the Idea of color regulating the quality of the an 
imal, can scarcely be supported. The Setter appenrs to originate from the Pointer and Spiniel. For hard work and endurance, he may be considered superior to the Pointer.

IVater Spaniel is larger than the Cocker Spaniel, his ears are longer and his coat more curly. He is superior to all others for aquatie jurposes, and is more particularly scrvicable in duck-shooting. His disposition is of the most aniable, and his affection unwarcring.

Cocker Spaniel is very much used in England, in Woodcock and Snipeshooting; is good on all kinds of game, rather inclined to be wild, is more difficult to train than Pointer or Setter. He is little used in the United States, as the method of training him is not generally understood. 'l'ìcre is a great variety of socalled Cocker Spaniels, varying in weight from 12 to $20 \mathrm{lbs}$. Their color is generally liver or liver and white. They appear never to tire, where either hair or feuther is at stake.

King Charles' Spaniel.-This breed takes it name from Clarles 2nd, who was the first to introduce them into England. Some suppose them to have originated in Japan, as there ex. 
ists there a brecd. somewhat similar yet larger. 'To be perfect, a Charles' Spaniel should haro 7 good points: round head, short nose, long cur. ly cars, large full eyes, color black and tan, without white, perfect symmetry of form, and under 10 lis. weight. Such is the original of the illustration: cost 44 Guincas in London. IIe is now in my possession. A short time ago, one was sold at public auction in England, and realized the sum of 525 guineas or over 2600 Dollars! They would be good hunting dogs, were they not too much enfeebled by confinement, indulgence, \&c.

Buerien Spaniel takes his name from a village near Oxford, England, where the breed has been kept particularly select. Ife is very much similiar in appearance to the King Charles, lut generally more delicate and slenter ; they are both no doulut of the same origin. The Blenheim varies in color; orange and white, blick anr tan and white, \&c., according to the fashion of the day.

ARCFr-Dog.-- The dog represented is of the maller breed of Polar-dogs, and was brought to New York in one of the ships of the "Kane Expectition." Weight about twenty pounds. 
He is remarkable for his actirity and vigilence, and his sense of hearing is far more acute than that of any other $\operatorname{dog} I$ lhave ever owned. He has pluck enough to face anything, but will never quarrel, except when jealous of attention, bestowed on others, when he becomes wholly ungovernable.

$J_{\text {APAN DOG.-This dog is the property of }}$ Captain McClooney, and was bronght by him in the Japan Expedition under Commodore Perry. He resembles slightly the Charley and Blenheim stock, but lacks their beanty and symmetry of form.

Engutsh MLASTFF has a serions, majestic air, is of a noble and courageous teniperament, disdaining eren to exchange civilities with an ordinary cur, or to take offense at trifling insults from his inferiors. He is rather slow in his morements, and perhaps not as rigilant as some of his cotemporaries ; yet the terror imposed hy his stern and resolnte aspeet may atone for his lack of activity. Iis lieiglit may be from 28 to 30 inches, and he is well proportioned and muscular.

BULL-DOG is the most courageous and un. flinching of the whole canine race. The pure 
breed is now rarely to be seen, and is well nigh extinct. 'The cross with the 'Terrier', (either Scotch or English), nroducos a superior animal, rivaling the Bull in pluck, and converting his dogged independence into a lively amalgamation of activity, beauty and nseful. ness. Whatever horrid ideas may be connected with the word Bull-dog, we are indebted to lim for much of the energy, pluck and endurance imparted to other breeds, which otherwise might liave fađed out.

Buld-Telraer is a closs from the Bull-dog and Terrier, and is one of the most useful guard-dogs now in nse. In the woods he is an overmatelı for the Badger, Fox, Skunk, Coon, \&c. His comrage is equal to that of the Bull. dog, and none can excel him in activity, vigilance or sagacity. No animal is more abused, or less deserving of it. The illustration represents my celebrated Dog, 'Tiger', to whom I am indebted for seventeen years of active service. Tiger knew about all that a dog can know, did all that any dog conld perform and was faithful even to death. (Sce his Life and Adventures, published by the Author.) Srotcu-terrier is a name now generally 
given to erery small sized dog, with a rough woolly pelt. 'The breed has raried perhaps more thin any other, on accomnt of the tendeney in cross breeds to moduce something litie the orig. inal. am there is no regulay standard, by which to test their purity. He is the hardiest of all dags, very comageous and particularlyzealous in the destruction of all linds of haip rermin.

Sire Tenruer is originally from the lsle of Skye to the north of Seotland. He is very rough, with long hody and short legs, has rather a weazley shape, and is a first rate rat killer.

WIRE 'TerRien is a cross between the Scotch and Huglish lerrier. and is quite as good ats either of them for destroying rats and other vermin. Gay, tough and renturesome, he rushes forward, in spite of lorake, briar or cat's claw.

Exighism Terrier (black and tan), is an elegant animal, when finely bred and well cared for. 'The illustration represents a female of the true old fashion breed. 'T'hese dogs are very quick and intelligent; gencrally excellent ratters and may be trained to hunt anything. 'I'hey vary greatly in weight, from two to 
twenty-five pounds, having of late years becn greatly refined by crossing with the Italian Greyhouml. If persisted in, this produces some very elesant suecimens, but their proportions generally lack symmetry, and they become deli. cate and unfit fol aetive service.

POODLE is well known the world over, and is famous for his funtastic performances and grmnastic excreises. 'They vary cxcecdingly in size and apprearance, \&c., from the different effects of climate and usage. Weight rarying from 2 to 60 lios. 'They are without courag'c, and their instrinsic value has yet to be revealed.

CoAcr-Dog, when full bred is a rery beautiful animal. If perfect, he should be evenly spotted from tip to tip. Each spot should be perfectly distinct and not interfere with another. There are several ramifications of these dogs: salit to be natives of Denmark, Dalnatia, \&c. 'They appear to form a stronger attachment to the horse, than any other animal, and are capable of performing long journeys, keeping exact pace with their favorite. The true breed is raluable and difficult to procure. 
REMAIRKS ON ILLUSTRATIONS.

Prince-dog, or Siberian Brood-hound.Prince is the largest Dow known in modern times; measuring 361.2 inches in height, 7 feet, 9 inches in length, reighinus over $2001 \mathrm{bs}$.

This breed was probably well known to the Romans in days of yore, whin the combat with wild beasts was a striking feature in the impe. rial pastimes. 'The Author hat the honor of introducing this celebrated Iog to $\mathrm{Her}$ Majesty and the Court at IVindsor Castle, when Prince was unanimously decided to be the King of Dogrs. I am still in possession of the stock.

Sugpuwa Dog, Scotch Colly, may be termed the most faithful of all Dogs. Te lives a lifo of sslitule, consequently ueither his manners not his morals ale corrupted. He is both master and slare to his flock, a perfect pattern of patience, fitelity and rencrelship.

'l'here are sundry virioties of the shepherd Dor, difering in size nul fature; every canine botonging to a shephert. being dubled with that title. 'The Scotch Colly weighs from 45 to $601 \mathrm{lbs}$.

'l'ne 'Tursspre derives his name from his 11) 
arocation. Weight from 15 to 20 lbs. ; long low and banty legred, resembling the German Beagle, though his nose is longer, and his ears shorter. He is snappish, suliea, and unsociable and has little but a good set of teeth to recon. mend him.

Tue Pugr-Dog was once a very fashionable and appropriate appendage to an old maid. He is not unlike the Bull-log, in appearance; yet his very antipodes in merit : barks at everything, but turus his back upon the mean. est foe. Color yellow, with black nose; tail thoroughly curled; weight from 15 to $25 \mathrm{lbs}$. His race is well nigh extinct, and who slall dare regret it?

Chinese Hatrless Dog.-A noted dish in the Celestial Empire. There is a variety of these Dogs. differing much in size, from 7 to $40 \mathrm{lbs}$. weight. In shape they are similar to the English Terricr. They are not very agreeab) to the toucl, and are alapted only for warm climates. They are active, intelligent and faithful, and worthy of a nobler fate than to be petted for the steir pan, or pampered for the pot. 
Sren-Dug...-These animals perform the duties of both Horse and Hound. Their endurance in harness is truly astonishing. They are accustomed to hard work, scanty fare aud ill-usacre; yet they never aesert their jost, or forsate their mister. They are natives of the extreme nothern latitudes, consequently ill. adapted to Southern climates.

ro them we are partially indebted for the dis coveries of Parry, Ross, I'Clintock, Kaue \&ic.

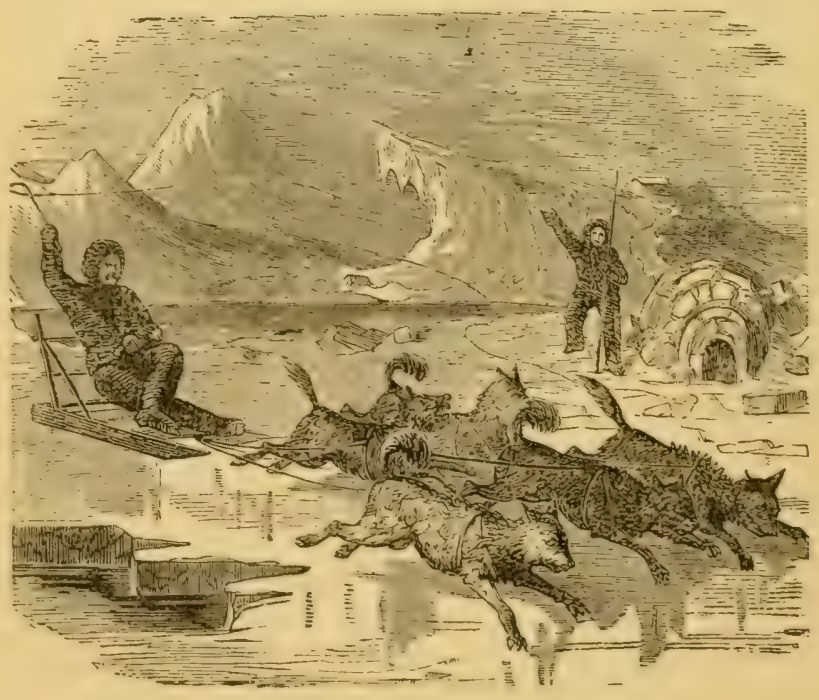




\section{PRACTICAL, IIINTS TO OIVNELS OF PL'T DOGS, \&c.}

Grve your dog a little less than he can eat, and a little more than he can drink. All food is better cooked. Avoid raw meat in hot weather. Kicep your pet from the fire; give a comfortable bed, but don't cover up. Don't let him get too lat; if he become too corpulent, shorten his fare and increase his esereise; if necd be, administer gentle aperients. Be carcful in washing to rub dry, and wrap well ul, till the trembling is past. Give your dogr a carcful examination at least once a week. beware of fleas: they create great excitement and in ritation, Mange, \&c., producing fits and perhaps consumption and death. Aroid all salt meats; $y$ ct a little salt should be added to ali that is in process of cooking. One groo' meal a day is enough for a sturdy dog; puppies and delicate animals had better be fed twice. 'T'o ensure a good watch dog', feed once a day, in the morning. His nocturnal vigils 


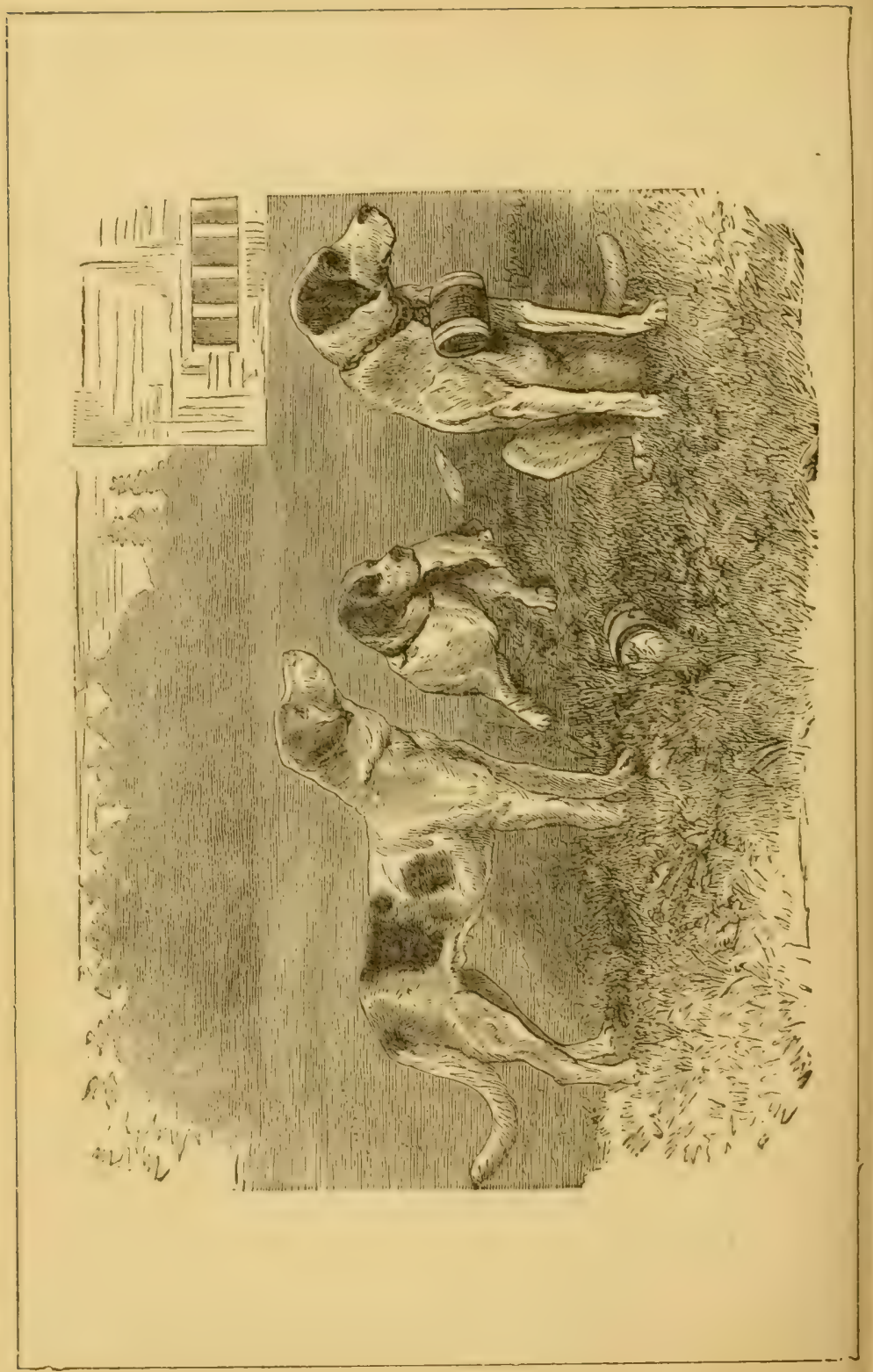


will be inspirited by his alulominal rearninga. I Fecl at regular hours and give a litle exercise immedialely after, to aroid a domestio catastrophe. be particularly carcful in fecel. ing puppice; they will always eat more than they can conveniently digest. Feed as littlo meat to them as possible, unless well amalya. mated with cooked meal or regretables. 'This rule is more or less applicab:e to the whole canine fraternity. Don't believe such indi. gestible nonsense, about a worm in a dog s tail, or under his tongue; place no faith in having his tail bitten olf; don't waste the lump of insoluble hrimstone in his water. Don't up. braid your dog for his indillerence, if you allow him hall'a-dozen masters. Don't admin. ister more punishment to him.than is absiblucly necesany, and nerer forget to make it up with him after a scourging. Never let a faux prs pass unreluked, nor a transgression unpar. doned. Let puppies have plenty of exereise, and sce that your watch dog has a staile, chain, collar and spring, that are perfectly loliable. Be eareful to gire cool slade in Eummer, and warm shelter iu winter. 


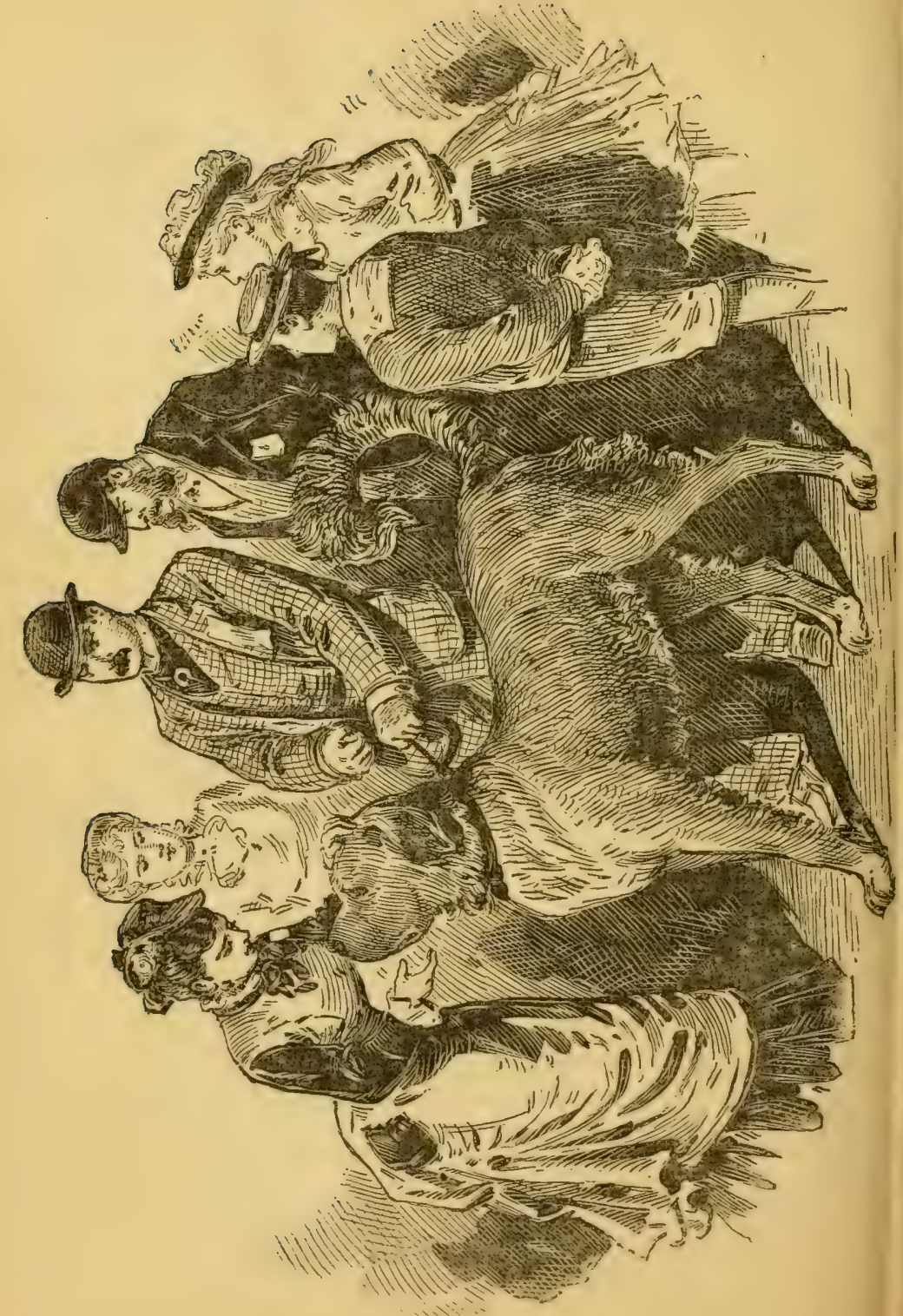




\section{APPENDIX.}

Mr: Edward Jesse, keeper of the Quecns Park, London, in his "Anecdotes of Dors:", las shown great research and study on this noble ainimal, which has been truly strled "the most faithful friend of man." In the following pages will be found many good things from his work:

A French writer has boldly affirmed, that with the exception of women there is nothing so agreeable, or so necessary to the comfort of m:n, as the dor. This assertion may rendily be disputel, but still it will be allowed that man, deprived of the companionship and services of the dog, would be a solitary and, in many respects, a helpless being. Let us look at the shepherd, as the evening closes in and his flock is dispersed over the almost inacessible heights of mountains; they are speedily collected lyy his indefatigable dog-nor do his services cud here: he guards either the flock or his masters' cottage by night, and a slight caress, an' the coarsest food, satisfy him for all his trouble. The dog performs the services of a hor'te in the 
more norther'n regions. In the destruction of wild beasts, or the less dangerous stag, or in attacking the bull, the dog has proved himself to possess pre-eminent courage. In many instances he has died in the defence of his master. He has saved him from drowning, warned him of approaching danger, served him faitufully in poverty and distress, and if deprived of sight las gently led him about. When spoken to; he tries to hold a conversation by the movement of his tail or the expression of his eyes. If his master wants amusement in the field or wood, he is clelighted to have an opportunity of procuring it for lim; if he finds himself in. solitude, his dog will be a checrful amel agreeable companion, and may be, when death comes, the last to forsalie the grave of his beloved master:

There are a thousand little facts comnected with dogs, which many, who do not love them as much as we do, may not lave observed, but which all tend to devolop their character. For instance, every one knows the fondness of dogs for warmth, and that they never appear more contented than when reposing on the rug before - a good inre. If, however, we quit the room, 
our dog leaves his warm hertl, and places himself at the door, where he can the better lear our footsteps, and be ready to greet us when we re-enter: If we are preparing to take a walk, our dog is instantly aware of our intention. He frisks and jump: about, and is all eagerness to accompany us. If we are thoughtiul or melancholy, he appears to sympathise with us; and, on the contrary, when we are disposed to be mery, he shows by his manner that he rejoices with us. TVe have often watched the effect which a change in our countenance would produce. If we frown or look severe, but without saying a word or uttering a sound, the effect is instantly seen by the cars dropping, and the eyes showing unhappiness. Before a dog, however, arrives at this knowledge of the human countenance, he must be the companion of your walks, repose at jour fect, and receive his food from youx hands: treater in this manner, the attachment of the dng is unbounded; be becomes fond, intelligent, and grateful. Whenever Stanislas, the unfortunate King of Poland, wrote to his rlaughter, he always concluded his letter with these words-"Tristan, my companion in misfortune, liclis your feet:" thus showing that he bad still one friend who stuck 
to him in his adversity. Such is the animal whose propensities, instincts, and habits, we propose to illustrate by various anecdotes.

I'he propensities of the dog, and some of them are most extraordinary, appear to be independent of that instinct which Paley calls, "a propensity previous to experience, and inde. pendent of instruction." Some of these are hereditary, or deriver from the liabits of the parents, and are suited to the purposes to which each breed has long been and is still applied. In fact, their orrans have a fitness or untituess for certain functions without education;- for instance, a very young puppy of the St. Bernard breed of dogs, when taken on snow for the first time, will begin to scratch it with considerable eagemess. We have seen a young pointer of three or four wecks old stand steadily on first secing poultry, and a well-bred terrier puppy will show a great deal of ferocity at the sight of a rat or mouse.

Some naturalists have endeavored to trace the origin of the dug from the fox; while others, and some of the most eminent ones, are of opinion that it sprung from the wolf. The former theory is out of the question. The wolf, perhaps, has some claim to be considered as the 
parent animal, and that he is susceptible of as strong attachment as the dog is proved by the following anecdote, related by Cuvier:

He informs us, that a young wolf was brought up as a dog, became familiar with every person. whom he was in the habit of seeing, and in particular, followed his master everywhere, evincing evident chagrin at his absence, obeying his voice, and showing a degree of submission scarcely differing in any respect from that of the domesticated dog. IIis master, being obliged to be absent for a time, presented lis pet to the Ménagerie du Roi, where the animal, confined in a cien, continued disconsolate, and would scarcely eat his food. At length, however, his health returned, he became attacherl to his lieepers, and appeared to have forgotten all his former affection; when, after an absence of eighteen months, his master returned. At the first word he uttered, the wolf, who had perceived him amongst the crowd, recognized him, and exhibited the most lively joy. On being set at liberty, the most affectionate caresses were lavished on his old master, such as the most attached dog would have shown after an absence of a few days.

A secund separation was followed by similar 
demonstrations of sorrow, which, however, again yielderl to time. 'l'hree years passerl, and the wolf was living happily in company with a dog, which had been placed with him, when his master again returned, and again the long-lost but still-remembered voice was instantly replied to by the most impatient cries, which were redoublel as soon as the poor animal was set at liberty; when rushing to his master, he threw lis fore-fect on his shoulders, licking his tace with the most lively joy, and menacing his keepers, who offered to remove him, and towards whom, not a moment before, he had been showing every mark of fondness.

A third separation, however, seemed to be too much for this faithful animal's temper. He became gloomy, desponding, refused his food, and for a long time his life appeared in great danger. His health at last returned, but he no longer suffered the caresses of any but his keepei, and towards strangers manifested the original savageness of his species.

It must, in fact, be always an interesting matter of inquiry respecting the descent of an animal so faithful to man, and so exclusively his as zociate and his friend, as the dog. Accordingly, this question has been entertained ever 
since Natural History took the rank of a science. But the origin of the dog is lost in antiquity. We find him oceupying a place in the earriest pagan worship; his name has been given to one of the first-mentioncl stars of the heavens, and his effigy may be seen in some of the most ancient works of art. Pliny was of opinion that there was no domestic animal without its un. subdued counterpart, and dogs are known to exist absolutely wild in various parts of the old and new world. The Dingo of New Holland, a magnificent animal of this kind, has been shown to be susceptible of mutual attachment in a singular degree, though none of the experiments yet made have prover that he is capable, like the domestie dog, of a similar attachment to man. The parentage of the wild dogs has been assigned to the tame species, strayed from the dominion of their masters. This, however, still remains a question, and there is reason to believe that the wild dog is just as much a native of the wilderness as the lion or tiger. 'If there be these doubts about an animal left for centuries in a state of nature, how can we expect to uniarel the difficulties accumulated by ages of domestication? Who knows for a certainty the true prototype of the goat, the sheep, or ox? 
To the unscientific reader such questions might appear idle, as having been settled from time immemorial; yet they have never been finally disposed of. 'The difficulty, as with the dogr, may be coniseted with modifications of form and color, resulting from the long continued interference of man with the breed and habits of animals subjected to this sway.

Buffon was very eloquent in behalf of the claim of the sheep-dog to be considered as the true ancestor of all other varieties. Mr. IIunter would awarl this clistinction to the wolf; supposing also that the jackal is the same animal a stcp further adranced towards civilization, or perhaps the dog returned to its wild state. As the affinity between wolf, jackal, fox, and dog, cannot fail to attract the notice of the most superficial observer; so he may ask if they do not all really belong to one species, morlified lig varieties of climate, food, and education? If answered in the negative, he would want to know what constitutes a species, little thinking that this question, apparently so simple, involves one of the nicest problems in natural history. Difference of form will searcely avail us here, for the pug. greyhound, and spaniel, are wider apart in this respect, than many dogs and the 
APPENDIX.

wild animals just named. It has olten been said that these varieties in the dog have arisen from artificial habits and breeding through a long succession of years. This seems very like mere conjecture. Can the greyhound be trained to the pointer's scent or the spanicl to the bulldog's firocity? But admitting the catuses assigned to be alcquate to the effects, then the forms would be temporary, and those of a perm znent kind only would serve our purpose. Of this nature is the shape of the pupil of the eye, which may be noticel somewhat particularly, not merely to make it plain to those who have never thought on the subject, but with the hope of leading them to reflections on this wondrous inlet to half our knowledge, the more especially as the part in question may be examined by any one in his own person by the help of a looking-glass. In the front of the eye then, just behind the transparent surfice, there is a solt of curtain called the iris, about the middle of which is a round hole. This is the pupil, and you will observe that it contracts in a strong light, and dilates in a weaker one, the object of which is to regulate the quantity of light admitted into the eyc. Now the figure of the pupil is not the same in all animals. In 
the horse it is oval; in the wolf, jackal, and dog; it is round, like our.own, however contracted; but in the fox, as in the cat, the pupil contracts vertically into an elongated figure, like the section of a lens, and even to a sort of slit, if the light be very strong.

This is a permanent character, not affected, as far as is at present known, by any artificial or natural circumstances to which the dog has been subjected. Naturalists, therefore, have seized upon this character as the ground for a division of animals of the dog kind, the great genus Canis of Linnæus, into two groups, the diumal and nocturnal; not to imply that these habits necessarily belong to all the imlividuals composing either of these divisions, for that would be untrue, but simply that the figure of the pupils corresponds with that frequently distinguishing diay-roaming animals from those that prowl only by night.

We will give a few anecdotes to show how different this animal is in his specific character to the wolf, and that he has a natural tendency to acknowledge man as his friend and protector, an instinct never shown by the wolf.

In Ceylon there are a great number of what are called wild dogs; that is, dogs who have no 
APPENDIX.

master, and who haunt villages and jungles, picking up what food they are able to find. If you mect one of these neglected animals, and only look at him with an expression of kindness, from that moment he attaches himself to you, owns you for his master, and will remain faithful to you for the remainder of his life.

"Man," says Burns, "is the God of the dog; he knows no other; and see how he worships him! With what reverence he crouches at his feet, with what reverence he looks up to him, with what delight he fuwns upon him, and with what chcerful alacrity he obeys him!"

Such is the animal which the brutality of man subjects to so much ill-treatment; its cliaracter depends very much on that of his master, kindness and confidence produce the same qualities in the dog, while ill-usage makes him sullen and distrustful of beings far more brutal than himself.

We have had many opportunities of olsserving how readily dogs comprehend language, and how they are aware when they are the subject of convcrsation. $\Lambda$ gentleman once said in the hearing of an old and favorite dog, who was at the time basking in the sun,_- must have Ponto killed, for he gets ald and is offensive." 
The dog slunk away, and never came near his master afterwards. Many similar anecdotes might be brought forward, but I will mention one which Captain Brown tells us he received himself from Sir Walter Scott.

"The wisest dog I ever had," said Sir Walter, "was what is called the bulldog terrier. I taught him to understand a great many words, insomuch that I an positive that the communication betwixt the canine species and ourselves might be greatly enlargerl. C:unp once bit the baker, who was bringing bread to the family. I beat him, and explained the enormity of his offence; after which, to the last of his life, he never heard the least allusion to the story, in what ever voice or tone it was mentioned, without getting up and retiring into tine darkest corner of the room, with great appearance of distress. Then if you said, "the baker was well paid," or, "the baker was not liurt after all," Camp came forth from his hiding-place, capered, and barked, and rejoiced. When he was unable, towards the cnd of his life, to attend me when on horscback, he used to watch for my return, and the servant would tell him "his master was coming down the liill, or through the moor," and although he clid not use 
any gesture to explain his moaning, Camp was never known to mistake him, but either went out at the front to go up the hill, or at the back to get down to the moor-side. He certainly had a singular knowlerlge of spoken language." An anecrloto from Sir Walter Scott must be always pleasing.

Mi: Smellic, in his "Philosophy of Natural History, mentions a curious instance of the intellectu.l ficulty of a dog. IIe states that "a groser in Elinburgh lad one which for some tims a:nusel an. astonis!rel the people in the neighbourhood. A man who went through the streets ringing a bell and selling pies, happened ons day to treat this dog with a pic. Tha next timo he hearil t'ıe picman's bell he ran impatuo: $3^{1} y$ towaril him, seized him by the coat and woald not suffer him to pass. The pieman, who un larsto.) I what the animal wanted, showed him a penny, and pointed to his master, who st:ml at tice st:"eet-door, and saw what was going on. Tha d is immediately supplicated his masta: by many humbl z gestures and looks, and on rasiving a penny lie instantly carried it in his mouth to the pieman, and received his pie. This traffic between the pieman and the grocer's 
dog continued to be daily practiced for several months."

The affections which some dogs show to theit masters and mistresses is not only very often surprising, but even affecting. An instance of this lately occured at Brighton. The wife of a member of the town council at that place had been an invalid for some time, and at last was confined to her bed. During this period she was constantly attended by a taithful and affectionate dog, who either slept in her room or outside her door. She died, was buried, and the dog followed the remains of his belored mistress to her grave. After the funeral, the hushand and his friends returned to the house, and while they were partaking of some refreshment the dog put his paws on his master's arm, as if to attract his attention, looked wistfinlly in his fice, and then laid down and instantly expired.

In giving miscellaneous anecdotes in order to show the general character of the dog, we will mention the following very curious one:

During a very severe frost and fall of snow in Scotland, the fowls did not make their appearance at the hour when they usually retired to roost, and no one knew what had become of them; the house-dog at last entered the kitchen, 
having in his mouth a hen, apparently dead. Forcing his way to the fire, the sagacious animal laid his charge down upon the warm hearth, and immediately set off. He soon came again with another, which he deposited in the sume place, and so continued till the whole of the poor birds were rescued. Wandering about the stack-yard, the fowls had beeome quite benumbed by the extreme cold, and had crowded together, when the dog observing them, effected their deliverance, for they all revived by the warmath of the fire.

Mr. Bell, in his "History of British Quadrupeds," gives us the following fact of a dog belonging to a frieud of his. This gentleman dropped a louis d'or one morning, when he was on the point of leaving his bouse. On returning late at night, he was told by his servant that the dog had fallen sick, and refused to eat, and, what appeared very strange, she would not suffer lim to take her food away from before her, but had been lying with her nose close to the vessel, without attempting to touch it. On Mr. Bell's friend entering the room, the dog instantly jumped upon him, laid the money at his feet, and began to devour his rictuals with great voracity. 
"It is a curious fact, says Mr. Jesse, that dogs can count time. I laad, when a boy, a favorite terrier, winich always went with me to church. My mother thinking that he attracted too much attention, ordered the servant to fasten him up every Sunday morning. He did so once or twice, but never afterwards. Trim conceiled himself every Sunday morning, and either met me as I entered the church, or I fourd him under my seat in the pew." Mr. Southey, in his "Omniana," intorms us that he knew of a dog, which was brought up by a Catholic and afterwards sold to a Protestant, but still refused to eat any meat on a Friday.

A gentleman who had a dog of a most endearing disposition, was ubliged to go on a journey periodically once a-month. His stay was short, and his departure and return very regular, and without variation. 'The dog always grew uneasy when he first lost his master, and moped in a comer, but recovered himself gradually as the time for his return approached; which he knew to an hour, nay to a minute. When he was convineed that his master was on the road, at no graat distance from home, he flew all over the house; and if the street door happened to be shut, he would sufler no servant to have any 
rest until it was opened. The moment he oitained his freelom away he went, and to a ecrtainty met his bencfietor about two miles fros: town. He played and frolicked about him till he had obtainerl one of his gloves, with which he ran or rather flew home, entered he housc, laid it down in the middle of the room, an.l danced around it. TWhen he had sufficiently amused himself in this manner, out of the house he flew, returned to meet his mastcr, and rin before him, or gambolled by his side, till he arrived with him at home. "I know not (says Mr. Dibdin, who relates this aneclote), how frequently this was repeated; but it lasted till the old gentleman was infirm, and ircapable of continuing his journeys.

Colonel IIamiltun Smith, in the "Cyclopæclia of Natural Ilistory," mentions a curious instance of fidelity and sagacity in a rog. Ile informs us that "in the neigborhood of Cupar, in the county of Fife, there lived two dogs, morial enemies to each other, and who always fought desperately whenever they met. Capt. $\mathrm{R}$ was the master of one of them, and the other belonged to a neighboring farmer. Capt. R--'s dog was in the practice of going messages, and even of bringing butchers' meat and other ar- 
ticles from Cupar. One day, while returning charged with a basket contanining some pieces of mutton, he was attaked by some of the curs of the town, who, no doubt, thought the prize worth contending for. The assault was fierce, amel of some durition; but the messenger, after doing his utmost, was overpowered and compelled to yidel un the basket, thomeh not before he liad secured a part of its contents. Tho pice sared from the wreck he ran off with, at full speed, to the quarters of his old enemy; at whose feet he laid it down, stretehing himself beside it till he had eaten it up. $\Lambda$ few smufl's, a fow whispers in the ear, and other dog-lilie courtesies, were then exchanged; after which 1licy hoth set ofl tewether for Cupar, where they worricel almost every dog in the town; and, what is more remarliable, they never afterwarls quarrenel, but were always on friemdly terms."

'That society and enlture solten and menerate the passion of dogs e:mot be doubted, and they constanty imbibe feclings from those of their master. Thus, if he is a coward, lis dog is erencrilly found to be one. Doges are, however, in many'respects, rational beings; and some pronfs of this will be given in the present work. They will wateh the comutemance of their mas. 
ter-they will understand worls which, thenterls adrlressed to others, they will ayply to themselves, and act aceordingly. Thuss a rlos, whirls from its mangy state, was ordered to be destroyed, tork the fir:t ofluontmuity of quitting the ship, and would nevere afterwards commen neate a sailor belonging to it. If I desire the scrvant to wash a little terrier, who is apparently asleep at my fect, he will quit the jomen, and hide limmself for some hours. $\Lambda$ dog, though pressed with hunger, will never seize a piece of meat in presence of his mater, thomeh with his r.y.s, his movenents, and his voice, he will make the most humble and expresive petituon. Is not this reasoning?

Buth the wild and romestio dor, aponear io be posiceserel of aturl to exercise firethourdit. They will hury or hirle forrl, which they are unable to consume at once, and return for it. But the domestic dore, lerbaps gives stronger proofs of foretionglit; and we will give an instance of it. 1 larese metal yot, turued on one side, in which a great quantity of porridge had been boilerl, was set before a Newloundlana puply of three or four months ojrl. At first, lie contented himself by licking ofi yromions of the vatmeal which adhererl to the interior, but 
findime this mantisfuctery, he seruphel the morsols with his fore-paws into a heilp, and then ate the whole at once. We had a dog, who, haring scalded his tongue, always afterwarls, when given his milk and water at hreakfast, put lis paw rery cautiously inte the saucre, to see if the liquid was too hot, be fore he would temeh it with his tongue.

Doges have lrequently leen known to huni in comples; that is, to assist (ach oflere in securing their prey:

At Palemo, in Sicily, there is an extraordinary quantity of dogs wamlering about without owners. Amongst the number, two more partieularly distinguisberl themselves for their animosity to calts. One dity they were in pursuit of a cat, which, seeing no other platee of refuge ne:ar, made her escape into a long carthen waterpipe which was lying on the gromul. These two inseparable companions, who always styprorted cach other, pursued the eat to the pipe, where they were seen to storl, and applarenty to consult each other as to what was to be done to deceive and gat prossession of the poor cant. Aiter they had stood a shert time they diviced,

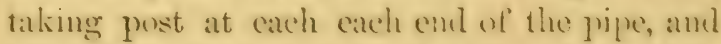
bran to bark alternately, chamging places while 


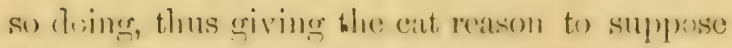
that they were both at one enrl, in order to induce her to come out. 'I'his mancenver hal a suecesful result, aml the cheited "at ledt her hidingrplace. Searecely hard she ventureel ont, when she was seized by one of the dngs; the other hastened to his assistance, and in a few moments deprived her of life.

In the small town of Melbourne, in Deroy-

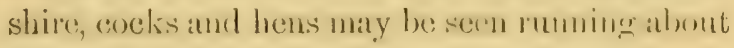
the streets. One dity a game cock attackerl a sinall bantam, and they fomght furiomsly, the bantam having of cours the worst of it. Some perans werestanding alont lowking at the fight, when my informant's homse-elog sudilenly darted out, suatches uj the bantam in his mouth, and earried it into his house. Several of the spec. tators followed, believing that the poor fowl would be killed and eaten by the rog ; but his intentions were of a more benevolent nature. After guarding the entrance of the kemuel for some time, he trotted down lhe yard into the street, looking aloout to the right and left, and sceing that the coast was clear, he went hack at gain, and once more retmaned with his portege in his month, saldely depresited him in the street, and then wallied quictly away. How few hu- 
man beings would lave acted as this dog had done! .

Here is another curious anecdote from Mr. Davy's work. He says that the cook in the house of a friend of his, a lady on whose accuracy he could rely, and from whom he had the ancedote, missed a marrow-bone. Suspicion fell on a well-behaved dog-a great favorite, and up to the time distinguished for his lionesty. He was charged with the theft; he lıung down his tail, and for a clay or two was altered in his manner, having become shy, sullen, and sheepish. In this mood he continued, till, to the amusement of the cook, he brought back the bone and laid it at. her feet. Then. with the restoration of her property, he resumed his checrful mannel: How can we interpret this conduct of the dog better than by supposing that he was aware he had done amiss, and that the evil-doing preyed on him till he had made restitution? Was not this a kind of moral sense?

If a $\log$ finds a bone while he is accompanying his master in a walk, he does not stay behind to gnaw it, but runs some distance in advance, attacks the bone, waits till his master comes up, and then proceeds forward again with 
it. By acting in this manner, ho never loses sight of his master.

A dog has been known to convey food to an. other of his species who was tied up and pining for want of it. A dog has frequentiy been seen to plinge voluntarily into a rapid stream, to rescue another that was in danger of drowning. IIe has defended helpless curs from the atticks of other dogs, and learns to apportion punishment according to the provocation received, frequently disdaining to exercise his power and strength on a weaker adversary. Repeated provocation will, horvever, excite revenge. For instance, a Newfoundland dog was quietly cating his mess of broth and broken scraps. While so employed, a turkey cndeavored t. share the meal with him. The dog growled, and displayed his teeth. The intruder retired for a moment, but quickly returned to the charge, and was again "warned off," with a like result. After three or four attempts of the same kind, the dog became provoked, gave a surden ferncious growl, bit off the delinquent's head, and then quietly finished his moal, without bestorving any further attention on his victim.

The celebrated Leibnitz relited to the French Academy an account of a $\log$ he had seen 
which was taught to speak, and could call in an intelligible manner for tea, coffee, chocolate, \&c.

The dog was of a middling size, and the property of a peasant in Sixony. A little boy, tho peasant's son, imagined that he perceived in the dogr's voice an inclistinct rescmblance to certain Woldis, and was, therérore, determined to teach him to spoak distinetly. For this purpose he spared neither time nor pains with his pupil, who was abont three years old when his learned edueation commenced; and at length he made such progress in lauguage, as to be able to articulate no less than thirty woris. It appears, however, that he was somewhat of a truant, and not very willingly exerted his talents, being rather pressed into the service of literature, and it was necessary that the worls should be first pronounced to him each time before he spoke. The French Academicians who mention this anecdote, add, thit uniess they had rescived the tastimony of so great a man as Leibnitz, they shoulst scarcely have dared to relate the circumstince.

" "An invalid gentleman" says Mr. Jesse, "who resided for some years on Ham Common, in Surey, had a dog which distinctly pronounced John, William, and two or three other words. 
A medical friend of mine who attonded this gentleman has frequently heard the animal utter these words; and a female relative of his, who was often at a visit at his house, assures me of the fact. Indeed it need not be doubteri."

$\Lambda$ dog; belonging to the late Dr. Robert Hooper, had been in the constant habit of performing various little personal services for his master, such as fetching his slippers, \&c. It happened one day that Dr. Hooper had been detained by his professional duties much beyond his usual dinner hour. The dog impatiently waited for his arrival, and he at last returned, weary and hungry. After showing his pleasure at the arrival of his master, greeting him wit's his usual attention, the animal remained tolerably quiet until he conceived a reasonable time had elapsed for the preparation of the Doctor's dinner. $\Lambda$ s it did not, however, make its appearance, the dog went into the listehen, seized with his mouth a half-broiled beef-steak, with which he hastened back to his master, placing it on the table-cloth before him.

The following aneedote shows extraordinary sense, if not reasoning faculty, in the dog:-

A lady of high rank has a sort of colley, or Scotch shepherd-dog. When he is ordered to 
ring the bell, he does so; but if ho is told to ring the bell when the servant is in the room whose duty it is to attend, he refuses, and then the following occurrence takes place. IIis mistress says, "Ring the bell, dog." The dog looks at the servant, and then barks his bow wow, once or twice. The order is repeated two cr three times. At last the dog lays hold of the servant's coat in a significant manner, just as if he had said to him_-"Don't you hear that I am to ring the bell for you ?-come, my lady." His mistress always had her shoes warmed before sise put them on, but one day during the hot weather her maid was putting them on without their having been previously placed before the fire. When the dog saw this he immeaiately interfered, expressing the greatest indignation at the maid's negligence. He took the shoes from her, carried them to the fire, and after they had been warmed as usual, he brought them back to his mistress with much apparent sitisfiction, evidently intending to say, if he could, "It is all right now."

At Albany in Worcestershire, at the seat of Admiral Maling, a dog went every day to meet the mail, and brought the bag in his mouth to the house. The distance was about an cighth 
of a mile. The dog usually received a meal of meat as his reward. The servants having, on one day only, neglected to give him his accustomed meal, the dog on the arrival of the next mail buried the bag, nor was it found without considerable search.

A gentleman residing in Denmark; M. Decouick, one of the king's privy councillors, found that he had a remarkable dog. It was the habit of Mr. Decouick to leave Copenhagen on Friclays for Drovengourd, his country seat. If he did not arrive there on the Friday evening, the $\operatorname{dog}$ would invariabiy be found at Copenbagen on Saturday moruing, in search of his master: Hydrophobia becoming common, all dogs were shot that were found running about, an exception being made in the case of Mr. Decouick's dog, on account of his sagacity and fidelity, a distinctive mark being placed upon him.

The following anectotes are from Daniel's "Rural Sports :"-

Dr. Beattie, in one of his ingenious and elegant essays, relates a story, in his own knowledge, of a gentleman's life being saved, who fell beneat' 1 the ice, by his dog's going in quest 
of assistance, and almost forcibly dragging a farmer to the spot.

Mr. Vaillant describes the losing cf a bitch while travelling in Africa, when after firing his gun, and fruitlessly searehing for her, he de. spatched one of his attendants, to retmin by the wiay they had proceerled; when she was found at about two leagues' distance, seated by the side of a chair and basket, which had dropped unperceived from his wagon: an instance of attentive ficlelity, which must have proved fatal to the animal, either from hunger or beasts of prey, had she not been luckily discovered.

As instances of the dog's sagacity, the following are submitted: In crossing the mountain St. Gothard, near Airola, the Chevalier Gaspard de Brandenberg and his servant were buried by an avalanche; his dog, who escaped the heap of snow, did not quit the place where he had lost his master: this was, fortunately, not far from the convent; the animal howled, ran to the convent frequently, and then returned. Struck by his perseverance, the next morning the people from the house followed him; he led them directly to the spot, scratched the snow, and after thirty-six hours passed beneath it, the chevalier and his domestic were taken out safe, 
hearing distinctly during their confinement the howling of the dog and the discourse of their deliverers. Sensible that to the sagacity and fondness of this creature he owed his life, the gentleman ordered by his will that be should be represented on his tomb with his dog; and at Zug, in the church of St. Oswald, where he was buried in 1728 , they still show the monument and the effigy of this gentleman, with the dog lying at his feet.

Colonel Iutchinson relates the following anecdote:-

"A cousin of one of my brother-officers was taking a walk at Tunbridge Wells, when a strange Newfoundland snatehed her parasol from lier hand, and carried it off. The lady followed the dog, who kept ahead, constantly looking back to see if she followed. 'The dog at length stopped at a confectioners, and went in, followed by the lady, who, as the dog would not resign it, applied to the shopman for assistance. He then told her that it was an old trick of the dog's to get a bun, and that if she would give him one be would return the property. She cheerfully did so, and the dog as willingly made the exchange."

The above anecdnte proves that dogs are no 
mean observers of comtenances, and that he had satislied himself by a previous scrutiny as to the probability of his delinquencies being forgiven.

We will give a laughable philosophical ac. count of dogs, under the supposition of a transmigration of souls, and with their general natural history from Lineus and Buffon, from a facetions believer in the art of distinguisling at the sight of any creature, from what class of animals his soul is derived.

The souis of deceased bailiffs and common constables are in the bodies of setting dogs and pointers; the terriers are inhubited by trading justices; the bloodlounds were formerly a set of informers, thief-takers, and filse evidenees; the spaniels were heretofore courtiers, hangerson of alministrations, and hack journal-writers, all of whom preserve their primitive qualities of fawning on their feeders, licking their hands, and snarling and snapping at all who offer to offend their master; a former train of gamblers and black-legs are now embodied m that species of dog called lurchers; bull-dogs and mastiff's were once butchers and drovers; greyhounds and hounds owe their animation to country squires and foxhuntcrs; little whiffling, useless 


\section{APPENDIX.}

lap-dogs, draw their existence from the quondam beau; macaronies, and gentlemen of the tippy, still being the playthings of ladies, and used for their diversion. There are also a set of sad dogs derived from attornies; and puppies, who were in past time attornies' clerlis, shopmen to retail haberdashers, mon-milliners, \&c. \&c. Turnspits are animated by old aldermen, who still enjoy the smell of the roast meat; that dronirg, snarling species, styled Dutch pugs, have been fellows of colleges: and that faithful, useful tribe of shepherd's dogs, were, in days of yore, members of parliament, who guarded the flock, and protected the sheep from wolves and thieves, although indeed of late some havo turned sheep-biters, and worried those they ought to have defended.

'The manner in which the shepherds of the Pyrenees employ their peculiar loreed of dogs, which are large, long-haired, of a tawny white color, and a very strong build, with a ferocious temper, exhibits a vivid instance of the trust they repose in the courage and fidelity of these animals, and of the virtues by which they merit and reward it. Attended by three or more dogs, the shepherds will take their numerous flocks at early dawn to the part of the moun- 
tain side which is destined for their pasture. IIaving counted them, they descend to follow other ocenpations, and commit the guardianship of the sheep to the sole watchfulness of the dogs. It has been frequently linown, that when wolves have approached, the three sentinels would walk round and round the flock, gradually compressing them into so small a circle that one dog might with ease overlook and protect them, and that this measure of caution being executed, the remaining two would set forth to engage the enemy, over whom, it is said, they invariably triumph.

It is now settled, as a philosophical question, that the instruction communicared to dogs, as well as various other animals, has an hereditary effect on the progeny. If a dog be taught to perform certain feats, the young of that rog will be much easier initiated in the same feats than other dogs. Thus, the existing races of English pointers are greatly more accomplished in their required duties than the original race of Spanish pointers. Dogs of the St. Bermard variety inherit the faculty of tracking footsteps in the snow. A gentleman of our acquaintance, and of scientific acquirements, obtained some years ago a pup, which had been produced 
in London by a female of the celebrated $\mathrm{S} t$. Bernard breed. The young animal was brought to Scotland, where it was never observed to give any particular tokens of a power of tracking footsteps until winter, when the ground became covered with snow. It then showed the most active inclination to follow footsteps; and so great was its power of doing so under these circumstances, that, when its master had crossed a field in the most curvilinear way, and caused other persons to cross his path in all directions, it nevertheless followed his course with the greatest precision. Here was a perfect revival of the habit of its Alpine fathers, with a degrce of specialty as to external conditions at which, it seems to us, we cannot sufficientiy wonder.

Such are some of the quilities of dogs in a state of domestication, and let us hope that the anecdotes related of them will tend to insure for them that love and gratitude to which their own fine disposition and noble character give them a claim fiom us.

It is pleasing to observe that men of the highest acquirements and most elevated minds have bestowed their sincere attachnent upon their favorite canine companions; for kindness to animals is, perhaps, as strong an indication of the 
possession of gencrous sentiments as any that can be adduced. The late Lord Grenville, a distinguished statesman, an elegant scholar, and an amiable man, affords an illustration of the opiuion: It is thus that he eloquently mates his fivorite Zephyr speak:

"Captum oculis, senioque hebetem, morboque gravatum, Dulcis here, antiquo me quod amore fores, Suave habet et carum Zephyrus tuus, et leriore Se sentit mortis comblitione premi.

Interiêre quiclem, tibi quæ placuisse solebant, Et formæ clotes, et facile ingenium:

Deficiunt sensus, tremulæ scintillula vitæ

Vix micat, in ciserem mox abitura brevem.

Sola manet, veruli tibi nec despecta ministri, Mens grata, ipsaque in morte memor domini. Hane tu iswitur, pro blanditiis molique lepore, Et promta ad nutus sedulitate tuos. Pro saltu cursuque levi, lusuque protervo,

Ifanc nostri extremum pignus amoris habe. Jamque vale! Elysii suboe loca lata, piorum Quæ dat Persephone manibus esse canum."

Pope sinys, that history is more full of examples of fidelity in the dog than in friends: and Lord Byron characterises him as-

"in life the firmest friend,

The first to welcome, foremost to defend;

Whose honest heart is still his master's own;

Whose labors, fights, lives, breathes for him alone; " and truly indeed may be called

"The rich mun's guardian, and the poor man's friend." 
APPENDIX.

\section{CANINE SUICLDE.}

In Bethlehem, Pa., there lived, a few years ago, a man named P., who kept a saloon by the side of the railroad, and was the owner of a ine Newfoundland dog, of great sagacity. The saloon was often visited liy boisterous and bel. ligerent customers, who were "spoiling for a fight," and considered a bar-tender as presenting the kest subject for a pummeling. In all such cases Mrr. P. only had to say "Mrajor," ancl the big Newfoundland had his paws on the shoulders of the pugnacious customer, looking him in the fuce. Tro or three artmonishing words from his capacious mouth was always a sufficient warning to keep the peace. He often amused the barroom crowal by his various tricks, among th.em was that of taking the lat from the head of any one in the room. Once a stranger came into the saloon to get some refreshments while waiting for the train. P. wished to show some half-dozen loungers Major's tricks, and ordered him to remove the stranger's hat. Major did as ordered, but the hair also came with the hat. The manceuver frightened the gentleman badly, and Mr. P., seeing the hair pealed from the gentleman's head, was more frightened than 
the stranger, and made haste to make amends. Major had great friendship for a little dog, a cross between the Poodle and the Seotch terrier. The little "Prince" was often set upon by his larger neighbors, and generally got the worst of it. In such cases be would sally forth in quest of his friend Major, when the fight was renewed and his assailant punished for his temerity. The little fellow was often, in summer time, partly sheared, which gave him, in the eyes of some, an ugly appearance. If any one made a derogatory remark about him, he noticed it, and showed his teeth in a very passionate manner. If Major was along, he also raised his roice in protest of any disapproval of his friend's looks. Major's master occasionally took too much of what he dispensed to others, and one evening, after sending Major to the field for the horses, which he drove up in good style, as was his practice, he followed his master up stairs. P., not finding wife or child to malireat, kicked poor Major down stairs, injuring his spine. He dragged out a miserable existence for a few months; but beenming tircd of life, he laid him. self across the railroad track that fronted the door. He saw the locomotive coming, and when it neared him, he turned? his head away, and al- 
lowed the train to crush him. This was witnessed by dozens of people, who lnew it to be a deliberate case of suicicle.

Another Newfoundland was installed in Major's place. The brutal master undertook to lick him around, but we are happy to say not without resentment, for he turned upen him, scizer lim by the throat, and would have choled him to cleath had not lis cries brought the bar-keepcr to his assistance.

The newspapers of the present week contain an account of a lighly prized Newfoundland clog in Walicficld, Mass.s, af.ce tugrging at his muzzle, placed on him in accordance with the law, became despondent, and soon afterward jumped into the pond and drowned himsclf.

The owncr of an oid watch dog some where in the Stute of Wisconsin, sceing that the dog was useless, and rathcr troublesome in consequence of arge, expresscd lis intention of shooting the old follow. This was said in the hearing of the dog, and within an hour he was missing, and was found a fow days afterwards in a pond near the house, where it was supposed that he had committed "dog-icide" by drowning bimself.

A Cantane Doctor.-There is a dog on 
Staten Island, that seems to be a sort of physician among the canines in his neighborhrod. If what rive hear of this dog is true, he is a wonder indeed. It is said that whenever he meets with any other dog that is sick, he wili by some mysterious intelligence inaluce the canine invalid, to follow him to the fields, and there eat of some grasses or weed, that in a few days effect a cure of the sick one. Several persons owners of dogs in the neighborhood, say from what they have witnessed that they believe, what is above stated.

Mr. II. Mr.Donald, in his lecture on oddness gives the following anecdotes about dogs :-

I once heard of a dog, from bis earliest puppy* hood would walk twice around his food before touching it, and always to the left. If called away by his owner before he had gone fully around the second time, he would finish the circle from the point or place at which he had left off. On one occasion while his master kept him at a distance, his meat was taken up and lairl on a bench. But on returning replaced it in nearly the exact spot it had been taken from, and then finished lis ring movement. The diameter of the circles were as nearly uniform, as a man might have them withou measurment. 
and were about four and a half feet. I will not attempt to explain or say what was the cause of this oddity. But as the owner of the dog averred that be had not been taught,and instinct it could nardly be called, I set it down to a habit acquired by circumstances.

A most curious trick of a couple of dogs I remember to have heard often in iny boyhood, and as the family in which the dogs were owned, were neighbors and friends of my Father's family. My memory was thoroughly impressed with the story, which is a true one. The two logs named respectively Carlo and Ponto, were of the large mastiff breed, and besides being excellent watch dogs, were also safe companions or escorts to tuke along for protection against insult or attack of any kind. Now it so liappened that one of the daughters of the fumily allucled too, who I shall call Miss Lena, was invited out to an aftermoon quilting party, that in the evening was to be turnerl into a party fur singing, and engaging in some of the old fashioned party plays, and of course the joung men of their acquaintance were to be present after tea time. It further happened that among these young men there was one who was introduced to Miss Lina, and who during the evening 
solicited the honor of sceing her home, a request that was readily granted. At the proper lour perhaps $12 \mathrm{P}$. M. they started homeward a distance of over two miles, Lena's two four fonted guardians, who had waited for her from the midule of the afternoon, joining in the escort. They did not however wag their tails, nor go bounding ahead nor stop to lick their Mistress' hand, as was their wont on other occasions, but simply trotted along behind the young couple in a sullen sort of a way with heads downward, and noses near together, as if in an undertone conversation. But when about a quarter of a mile on the way, Carlo without even a warning, gravely laid hold of Miss Lena's young man escort by the leg of his trousers, and would not permit him to move on any further, and neither the threats, blows, nor coaxings, of Miss isena, could induce him to let go his hold. The other dog took no part in the arrest, but trotted briskly a few yards ahead, indicating that he was ready for escort duty. The gentleman suggested to the young lady to accept the offer apparently made by Ponto, and that after she had started he would be set free, she did so reluctantly of course, and was soon joined by Carlo. The cscort did not deem it healthy to make an effort 
to regain his position. Now the question that maturally presents itself is, were the dogs jealous of the attentions of the rival escort, and I think all will admit that such was the fact. If so how did they arrange their plan of rerenge, on their rival? Is there a language by which animals can make linown their thoughts to each other. It almost seems as if it was so. The story may seem like a very strancre one, and though I am certain of its truth, it does nevertheless seem odd even to me.

Some years ago a large Newfoundland rlog was honored with a metal, upon which was inscribed "A distinguished member of the IImane Society." Among the well-authenticated accounts of his usefulness is that of rescuing the crew of a vessel driven on the beach of Lydd, in Kent. Eight poor fellows were crying for help, but no boat could live in endeavoring to go to their assistance. At length a gentleman came on the beach accompanied by a Newfoundland dog. Ile directed the attention of the animal to the ressel, and put a short stick in his moutl. The intelligent and courageous fellow at once understood his meaning, springing into the sea, he fought his way through the wares. He could not, however, got close enough 
to the vessel to deliver that with which he was charged; but the crew understood what was meant, and they made fast a rope to another piece of wood, and threw it toward him. The noble creature dropped the one in his mouth, and seized that which had been cast to him, and then, with a degree of strength and determination scarcely credible-for he was again and again lost under the waves-he dragged it through the surge, and delivered it to his master ; a line of communication was thus formed with the boat, and all on board were saved.

"Juno" was a dog in which were mingled the blool of the spaniel and Newfoundland, and rescended from a family remarkable for intelligence; for with dogs, even more than with men, talents are hereditary. This playful, intelligent creature, without any instruction, performed so many feats that she won a wide celebrity. So fond was she of her reasoning playmates, that she would at any time abandon her puppies to have a romp with the children. As a nurse, she took care of "the baby," and would follow it about, pick up its playthings, rock its cradle, and carefully restore to its hands the "chicken bone," for the moment dropped on the floor. Having once accompanied her master on 
a fishing excursion, she afterward wonld dig angleworms, draw the fishing-rod from its hooks, and insist in the stable that the horse should be saddled, and then lead the animal by the bridle up to the door. Her kind care exteuded to the chickens and ducks, and if any of the little ones were lamed or died, she at nightiall took them to their respective owners, and thrust them under the maternal wing. When the garden was made Juno seemed to admire the nicely-arranged beds, and throughout the whole summer, looked through the palings with indignation at what she supposed to be the intruding plants in the nicely-prepared ground.

Juno never would allow the servants to possess in pare any property once belonging to her master; mistress, or their children, which was not formally given away in her presence; in that cass, she never noticed the articles at all. In New Orleans this dog attracted a great deal of attention, because she would not touch the poisoned sausages thrown into the street. She did not confine her useful labors exclusively to those who owned her, but would restore lost property, wheu she met with it, that belorged to any of the neighbors. She appeared to understand the meaning of words, and would in- 
stantly show by her manner how perfectly she comprehended the passing conversation. It any subject was alluded to in which she took an interest, she would bark and caper about, and dusignate as far as possible the different things allurlel to. She would remain perfectly quict, with an affectionate eye alone upon her master, through long discussions on polities or philusop.ry ; but let anything be said about angling or hunting, about the poultry in the yard, or kindred subjects, and she wouli go almost crazy with delight. This log, combining within herself the qualities of the two most intelligent brueds of her kind, seemed but little removed from a reasoning, intelligent being; there were, at times, expressions in her cre, of affection, of thought, of sorrow, of joy, so very human that it was painful, and startled the imagination for the moment with the idea that Pythagoras was indeed correct, and that the souls of formermen were imprisoned in the bodies of animals; for it was easy, in contemplating this remarkable doy: to suppose that she was possessed of a hilden intelligence not properly belonging to bruts life. And yet Juno was only one of the many intelligent beings so frequently to be met with among the dogs, who, in their humble 
sphere, teach us lessons of devotion, disinterestedness, and friendship.

India is remarkable for wild dogs, among which is the poor Pariah, an inhabitant of the confines of civilization, and yet is nerer fairly adopted into human society. This dog, naturally gentle, a British officer relates, was caught by the natives in great numbers, and used to feed a tiger, liept in the garrison for the amusement of visitors. On one occasion, a pariah, instead of yielding to fear, stood on the defensive, and as the tiger approached he siczed him by the upper lip. This continued to be done several days, when the tiger not only ceased his attacks but divirled his food with the poor dog, and became his friend, and the two animals occupied the same eage for many years. An old lion, in the Tower of London, conceived a liking for a little dog that accidentally got into his cage, and the two animals became inseparable. It was a source of great amusement to observe the impudence of the little puppy, who would bark at visitors while the old lion would lonk dignifiedly on, seemingly determined to assist his little friend out of any difficulties lis presumption might lead to.

Some years ago, it was not uncommon in 
Connecticut to employ dogs as motive-power to light machinery. $\mathrm{A} \mathrm{Mr}$. Brill had a pair of dogs which he employed together on a sort of tread-mill. After a while the motion of the machinery was noticed from time to time to he considerably retarded, when the tender would go to the mill to see if the dogs were doing their duty, and every thing appeared to be right. Another and another interruption would occur, and so continued, until the owner began to suspect that his dogs were playing some trick upon him. Accordingly he placed an observer where all the movements of the animals could be seen, and the mystery was thus explained. After the two dogs had wrought together for some time, one of them was seen to step off the treacmill and seat himself where he could catch the first warning of any approaching foot-step. After he had rested awhile he took his place at the wheel again, and allowed his associate to rest: thus these sagacious creatures continued to bear each other's burdens.

An unfortunate dog, in order to make sport for some fools, had a pan tied to his tail, and was sent off on his travels to a neighboring town. IIe reached his place of destination perfectly exhaustel, and lay down before the steps 
of a tavern, eycing most anxiously the horrid amoyance fastened behind him, but mable to move a step farther to rid himself of the torment. Another dog; a Scotch shepherd, laid himself down beside him, anrl, ly a few caresses, gaining the confictence of the afflicterl cur, proceeded to gnaw the string by which the 1inisy appendage was attacherl to his fricnd's tail, and with about a quarter of an hour's excrion, severed the cord, and started to his legs, with the pan hanging from the string in lis moutl, and after a few joyful capers, reparted on his travels in the highest glee at his success.

Some years ago, while traveling up the Mis. sissiply river, in common witil other passengers on the steam we were attracteil by the docility and intelligence of a pointer dog. This excellent animal. woule voluntarily return mislaic books, hats, or other trifles to their owners, and seemed to desire to render himself popular by doing such kindly offices. The trick he pelformed, however, which created most surprisc, was taking notes from gentlemen to their wives in the ludies' cabin. This be would do whenever called upon. The person sending the note, would simply call the dog, and his master would give him the cirections what to do, and we be- 
lieve he never made a mistake. The dog would take the paper in his mouth, go among the lady passengers and hunt around, and finally put the note in the lap of the person for whom it was intended.

The son of Dr. Dwight relates, that his father, the greatest theological writer our country has ever produced, was indebted to a dog for his life, the faithful animal obtruding in his pathway, and compelling his horse to turn out of the ruad he was traveling. In the morning the Dictor discovered that if ho had pursued his journey according to his intent, he would have been dashed down a precipice, where to escape with bis life would have been an impossibility.

An English gentleman discovered, one morning, that some miscreant har cut off the ears and tail of a favorite horse. A blood-hound was brought to the stable, which at once detected the scent of the villain, and traced it more than twenty miles. The hound then stopped at a door, whence no power could move him. Being at length admitted, he ran to the top of the house, and, bursting open the door of a garret room, found the object he sougint in bed, and would have torn him to pieces, had not the 
huntsman, who had followed lec dog on a flect horse, rushed to the reseue.

A Miss Childs, a keeper of a tavern in London, quite recently posscesed a black and white spaniel which performed tricks almost surpass. ing belief. This dog could plity at ganes of whist, cribbage, and dominoce. In playing these games the dog was placed behind a screen, and had the carls all arranged before him; over this sercen he watelsed his antagonist, and reached with his mouth the silite required. Out of a pack of cards he would instantly select the best, cribbage and whist. On the names of any eity, county, or town being placed by printed cards before lin, the dog would, without hesitrtion, fateh the one requested, and at the bidding of any one present, and in the absence of his mistress. IIe could, by the aid of printed cards, tell how many persons might be in the room, how many hats, or the number of coins any one might throw on the floor. After being taken out of the room, if any one present touched a card, the dog on his return would designate it. So numerous, indeed, were the evidences of intelligence exhibited by this dog, that it was impossible to resist the impression that he was possessed of reason. 
APPENDIX.

The following anecdotes of an astonishing dug called "Dandie," are related by Captain Brown:-

"Mr. M'Intyre, patent-mangle manufacturer, Regent Bridge, Ediuburgh, has a dog of the Newfoundland breed, crussed with some other, named Dandie, whose sagacious qualifications are truly astonishing, and almost incredible. "When Mr. N'Intyre is in company, how numerous soever it may be, if he but say to the dog, "Dandie, bring me my hat," he immediately picks out the hat from all the others. and puts it in his master's hand. "Should every. gentleman in company throw a peulnife on the flonr, the rogr, when commanded, will select his master's knife from the heap, and bring it to him. A pack of eards being scattered in the room, if his master has previously selected one of them, the dog will find it out and bring it to him. A comb was hid on the top of a mantla-piece in the room, and the dog required to bring it, which he almost immediately did, although in the search he found a number of articles, also belonging to his master, purposely strewerl around, all which he passed over, and brought the identical comb which he was required to find, fully proving that he is not guided by the sense of 
smell, but that he perfectly understands whatever is spoken to him. One evening, some gentlemen being in company, one of them accirientally dropped a shilling on the floor, which, after the most careful search, could not be found. Mrr. M'Intyre seeing his dog sitting in a corner, and looking as if unconseious of what was passing, said to him, "Dandie, find us the shilling, and you shall have a biscuit." The dog immediately jumped upon the table and laid down the shilling, which he had previously picked up without having been perceived. One time baving been left in a room in the house of a lady, he remained quiet for a considerable time; but as no one opened the door, he became impatient, and rang the bell; and when the servant opened the door, she was surprised to find the dog pulling the bell-rope. Since that period, which was the first time he was observed to do it, he pulls the bell whenever he desires; and what appears still more remarkable, if there is no bell-rope in the room, he will examine the table, and if he finds a hand-bell, he takes it in his mouth and rings it. His master, one evening having supped with a friend, on his return home, as it, was rather lite, he found all the family in bed. He could no. find his boot-jack in the place 
where it usually lav, nor could he find it anywhere in the room aftel the strictest search. He then said to his dog, "Dandie, I cannot find my bootjack; search for it." The faithful animal, quite sensible of what had been said to him, scratching at the room-door, which his master opened. Dandie proceeded to a very distant part of the house, and soon returned, carrying in his mouth the bootjack, which Mr. M. now recollected to have lefit that morning under a sofa.

A number of gentlemen, well acquainted with Dandie, are daily in the habit of giving him a peuny, which he takes to the baker's shop and purchases bread for himself. One of these gentlemen, who lives in James's Square, when passing some time ago, was accosted by Dandie, in expectation of his usual present. $\mathrm{Mr}$. T then said to him, "I have not a penny with me to-day, but I have one at home." Having returned to his house some time after, he heard a noise at the door, which was opened by the servant, when in sprang Dandie to receive his per. ny. In a frolic Mr. T-gave him a bad one, which he, as usual, carried to the baker, but was refused his bread, as the money was bad. He immediately returned to $\mathrm{Mr}$. $\mathrm{T}$ _'s, knoclied 
at the door, and when the servant opened it, laid the penny down at her feet, and walked ofl; scemingly with the greatest contempt. Althougii Dandie, in general, makes an immediate purchase of bread with the money he receives, yet the following circumstance clearly demonstrates that he possesses more prudent foresight than many who are reckoned rational beings. One Sunday, when it was very unlikely that he could have received a present of money, Dandic was observed to bring home a loaf. $\mathrm{Mr}$. M'Intyre being somewhat surprised at this, desired the servant to search the room to see if any money could be found. While she was engaged in this task, the dog seemed quite unenncerned till she approached the berl, when he ran to her, and gently drew her back from it. Mr. M. then secured the dog, which kept struggling and growling while the servant went under the bed, where she found $7_{2}^{1} d$. under a bit of cloth; but from that time he never could endure the girl, and was frequently observed to hide his money in a corner of a saw pit, under the dust.

When Mr. M. has company, if he desires the dog to see any one of the gentlemen home, it will walls with him till he reach his home, and 
then return to his master, how great soever the distance may be. A brother of Mr. M.'s and another gentleman went one day to Newharen, and took Dandic along with them. After hav. ing bathed, they entered a garden in the town; and having taken some refreshment in one of the arbors, they took a walk around the garlen, the gentleman leaving his liat and gloves in the place. In the meantime some strangers came into the garden, and went into the arbor which the others had left. Dindie immediately, without being ordered, ran to the place and brought off the hat and gloves, which he presented to the owner. One of the gloves, however, had been left; but it was no somer mentioned to the dog than he rushed to the place, jumped a. gain into the midst of the company: and brought oft the glove in triumpl.

A gentleman living with Mr. MIntrre, going out to supper one erening, locked the garlengate behind him, and laid the liey on the top) of the wall, which is about seven feet high. When he returned, expecting to let himself in the same way, to his grat surprise the key could not be found, and he was obliged to go round to the front inor, which was a consilerable distance about. The next moming strict 
search was made for the key, but still no trace of it could be disenvered. $\Lambda$ t last, perceiving that the dog followed him wherever he went, he said to him, "Dandie, you have the key-gro, fetch it." Dandie immediately went into the garden and scratched away the earth from the root of a cabloage, and producel the liey, which he himself had undoubtedly hid in that place. If his master places him on a chair, and requests him to sing, he will instantly commence howling, high, or low, as signs are made to him with the finger.

Ahout three years ago a mangle was sent hy a cart from the warchouse, Regent Bridge, to Portobello, at which time the dorg was not present. Afterwards, Mr. M. went to his own house, North Back of the Canongate, and tor)] Dandie with him, to have the mangle delivered. When he had proceerled a little way the dog ran off, and he lost sight of him. He still wallied forward; and in a littie time he found the cart in which the mangle was, turnerl towards Edinburgh, with Dandie holding fast by the reins, and the carter in the greatest perplexity; the man stated that the dog had overtaken lim, jumped on his cart, and examined the mangle, and then had seized the reins of the horse and 
turned him fairly round, and that he would not let go his hold, although he had beaten him with a stick. On Mr. M.'s arrival however, the dug quictly allowed the carter to proceed to his place of destination.

"TAG," a large Newfoundland dog was put to work in a dog power wheel used for churn. ing purposes, but from the first showerl a deciled dislike for labor. Having been hurt in a fore foot a few months afterwards, he had a rest for a couple of weeks to parmit of his foot getting well. When put in the power again he refused to turn it, but held up the foot that had been lame, and howled as if in great pain. His owner suyposing that he had perhaps strained the lame foot, let him out, and 'Tag limped off' on three legs, but was soon discorered dashing across a meadow in company with a neiglıbor's dog, as though he had never been lame. He was called in and again put in the power, and again held up his foot and howled, but a cut or two of the whip convinced him that his trick was seen through. so he weut rlogfully to work, and nothing of 'Tays's lameness was afterward seen. 


\section{MLNOS, THE LEARNED DOG.}

A very learned man has just written a long article for one of the magazines to prove that dogs, horses and birds have souls. Of course we cannot all agree with him ; but we are ready enough to admit that these creatures have minds, -pretty active ones too-whether they have souls or not. Minos, the dog, on page 18t, is a wonderful little fellow. He came from Havana, and is now being exhibited in France. His mistress, Maulame IIager, has taught him to answer questions which would puzzle some children seven years old. He finds a given number correctly; works out examples in addition, subtraction and division; he can read words that are written and placed before him, and indeed does so many remarkable things that fashionable people in Paris are glad to have lim and his mistress visit them at their elegant houses.

Now if a poor dumb dog can learn so much by being simply attentive and obedient, what ought we not to expect of wide-awake boys and girls who can talk, and have not only active minds, but souls as well? 
APPENDIX.

Mr: Youatt gives the following anecrote as a proof of the reasoning power of a Newfoundland dog.

Waiting one day to go through a tall iron gate, from one part of his premises to another, he found a lame puppy lying just within it, so that he could not get in without rolling the poor animal over, and perhaps injuring it. $\mathrm{MI}_{\mathrm{r}}$. Youatt stood for awhile hesitating what to do, and at length determined to go round through anuther gate. A fine Newfoundland dog, however, who had been waiting patiently for his wonted caresses, and perhaps wondering why lis master did not get in as usual, looked accidentally down at his lame companion. He comprehended the whole business in a momentput down his great jaw, and as gently and quickly as possible rolled the invalid out of the way, and then drew himself back in order to leave room for the opening of the gate.

We may be inclined to deny reasoning faculties to dogs: but if this was not reason, it may be difficult to define what else it could be.

MIr: Youatt also says, that his own experience furnishes him with an instance of the memory and gratitude of a Newfoundland dog, who was greatly attached to him. He says, as it became 
inconvenient to him to keep the dog, he gave him to one who he knew would treat him kindly. Four years passed, and he had not seen him; when one day as he was walking towards Kingston, he met Carlo and his master: The dog recollected Mr. Youatt in a moment, and they made much of each other. His master, after a little chat, proceeded towards Wandsworth, and Carlo, as in duty bound, followed him. Mr. Youatt had not, however, got halfway down the hill when the dog was again at his side, lowly but deeply growling, and every hair bristling. On looking about, he saw two ill-looking fellows making their way through the bushes, which occupied the angular space between Rockhampton and Wandsworth roads. Their intention was scarcely questionable, and, indeed, a week or two before, he bad narrowly escaped from two miscreants like them. "I can scarcely say," proceeds Mr. Youatt, "what I felt; for presently one of the scoundrels emerged from the bushes, not twenty yards from me; but he no sooner saw my companion, and hearl his growling, the loudness and depth of which were fearfully increasing, than he retreated, and I saw no more of him or his associate. My gallant defender accompanied me to the direc- 
APPENDIX.

tion-post at the bottom of the hill, and there, with many a mutual and honest grecting, we parted, and he bounded away to overtake liis rightful owner. We never net again; but I need not say that I often thought of him with. admiration and gratitude."

Newfoundland dogs may readily be taught to rescue drowning persons In France, this forms a part of their education, and they are now keps in reaciness on the banks of the Seine, where they form a sort of Humane Society Corps. By throwing the stuffel figure of a man into a river, and requiring the dog to fetch it out, he is soon taught to do so when necessary, and thus he is able to rescue drowning persors. This hint might not be thrown away on our own excellent Humane Society.

The Newfoumdland $\operatorname{dog}$ may be broken into any kind of shnoting, and, without additional instruction, is generally under such command, that he may be safely kept in, if required to be taken out with pointers. For finding wounded game of every description there is not his equal in the canine race, and he is a sine qua non in the general pursuit of wild-fowl. These dogs should be treated gently, and much encouraged when required to do anything, as their 
faults are easily checked. If used roughly, they are apt to turn sulky. They will also recollect and avenge an injury. A traveller on horscback, in passing through a small village in Cumberland, observed a Newfoundland dog reposing by the side of the road, and from mere wantonness, gave him a blow with his whip. The animal made a violent rush at and pursued him a considerable distance. Having to proceed throngh the same place the next journey, which was about twelve months afterwarks, and while in the act of leading his horse, the dog no doubt recollecting his former assailant, instantly seized him by the boot, and bit his leg. Some perisons, however, coming up, rescued him from further injury.

A gentleman who had a country house near London, discovered on arriving at it one day that he had brought away a key, which would be wanted by his family in town. Having an intelligent Newfoundland dog, which had been acenstomed to carry things, he scnt him back with it. While passing with the key, the animal was attacked by a butcher's dog, against, which he macle no resistance, but got away from him. After safely delivering the key, he re. turned to rejoin his master, but stopped in the 
Way at the butcher's shop, whose dog again Eallied forth. The Newfoundland this time attacked him with fury, which nothing but revenge could liave inspired, nor dicl le quit the agresso" till he lad killed him.

A ggentleman in Ireland had a remarkable fine and jutelligent Newfoundland dog, named Boatswain, whose acts were the constant theme of admiration. On one occsion, an aged lady who resided in the house, and the mother-in-law of the owner of the dog, was indisposed and confined to her bed. The old lady was tired of chickens and other productions of the farmyard, and a consultation was held in her room as to what could be procured to please her faney for dinner. Various things were mentioned aud declined, in the midst of which Boatswain, who was greatly attached to the old lady, entered the room with a young rabb:t in his mouth, which he laid at the foot of the bed, wagging his tail with great exultation. It is not meant to infer that the dog knew anything of the difficulty of finding a dinner to the larly's taste, but seeing ber distressed in rnind and body, it is not improbable that he had brought his offering in the hopes of pleasing her.

On another occasion, his master found this 
dog early one sumincr's morning liceping watch over an unfortunate countryman, who was standing with his back to a wall in the rear of the premises, pale with terror. Ue was a simple, honest creature, living in the neighborhood. Having to attend some f.iir or market, about four o'clock in the morning, he made a short cut through the grounds, which were under the protection of Boatswain, who drove the intruder to the wall, and kept him the:e, showing his teeth, and giving a growl whenever he offered to stir from the spot. In this way he was liept a prisoner till the owner of the faithful animal released him.

A gentleman had a shepherd dog, which was generally kept in a yard by the side of his house in the country. One day a beggar made his way into the yard, armed with a stout stick, with which be defended himself from the attacks of the dog. who barked at and attempted to bite him. On the appearance of a servant the dog ceased barking: and watshing his opportunity, he got behind the beggar, snatched the stick from his hand, and carried it into the road, where he left it. 


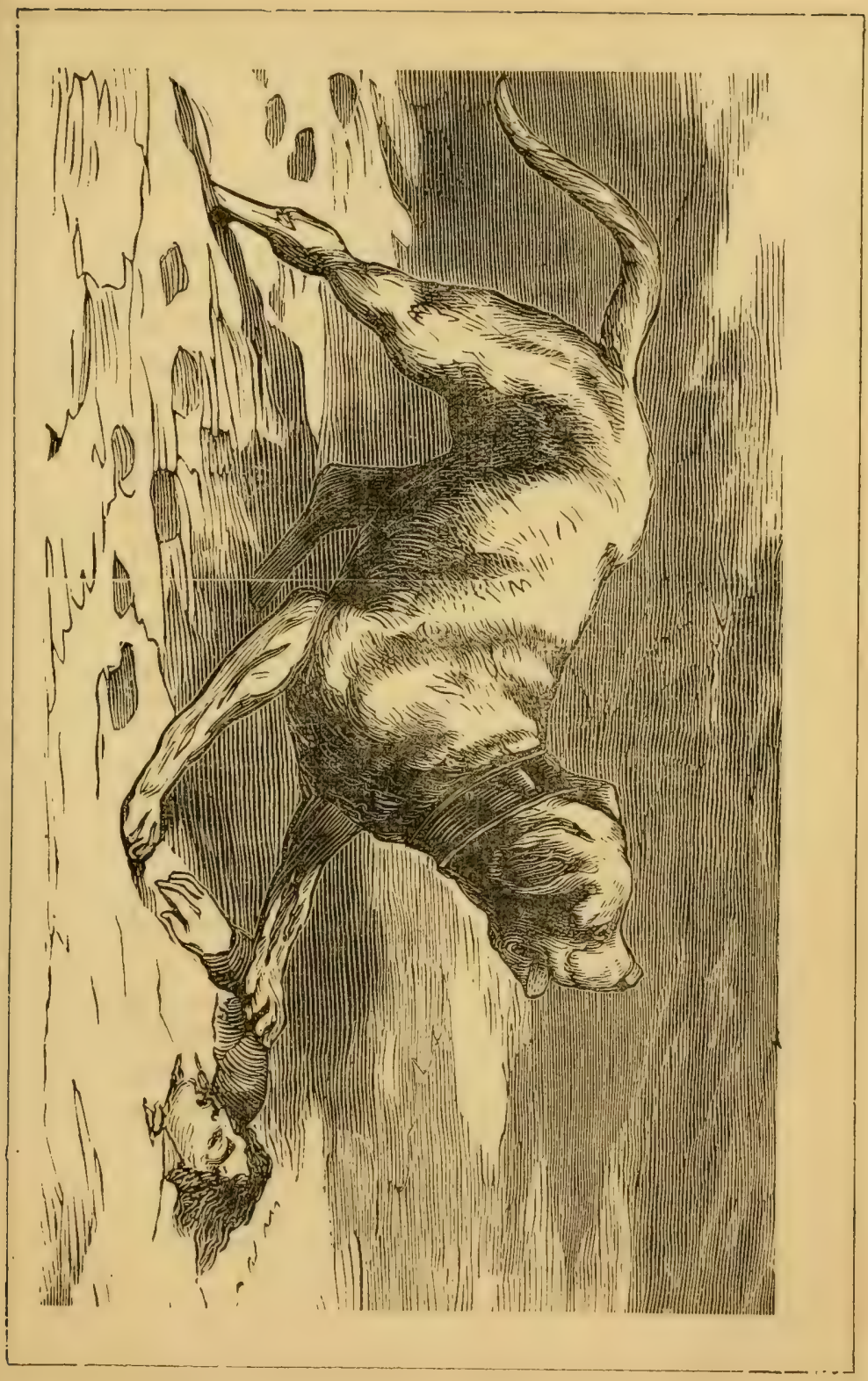


APPENDIX.

\section{BRAVE DUKE, THE MASTIFF.}

The picture on the opposite page portrays the scene of an attempted murcier in the $P_{y}$ renees, of a young Englishman, by a relative, who was next of kin, and would, by the young man's death, become heir to a vast estate. While making a tour of the continent, the young man was joined by this treacherous relative, who murderously knocked him from a cliff, into a snow-choked chasm, many feet beneath. The snow that was expected to form his winding sheet, and forever conceal his corpse, and the heinous crime committed upon him, from mortal eye, was a cushion to shield him from being dashed to atoms, and his faithful dog "Duke," penetrated the suow till he found him, and then went for assistance, which be conducted to the spot by his signs of distress. The mercenary relative, to save himself from his dastardly deed ended his life by his own band. 
Mr. Millar, a Scotch gentleman, a resident of Melbourne, Australia, entertained the opinion that dogs of ordinury sagacity were capable of recognizing the members of a family which they had not previously seen. He claimed they could do it from resemblance, and also by the scent, which must be similar in families. IIe had an opportunity of proving very conclusively, both of these theories. The incident was related to us by nene of the participants, a lady, now residing in Brooklyn:

While traveling near Melbourne, Mr. Millar was followed home by a young Retriever: Finding him to be a valuable dog, he advertised for the owner, but failing to find one, "Jennie" was installed as the housshold pet and grardian. Two smail children were always accompanied in their walks by her, and no stranger could as much as lay a hand on them. A side gate, near which was her kennel, was guarded against strangers, with the greatest fierceness. At the time of Jennie's installation Miss Lucy, a daughter of fifteen, was away at school, Millar considered her return home wonld afford a good opportunity to test his theory. "Jennie" had in her kennel, near the guarded gate, a litter of young pups, and was uncommonly savage, but 
Mr. Millar did not hesitate to send his daughter alone to the lane and through the gate, which she had barely passed, before the dog came at her in full speed, and with such sarageness that her stout heart quailed. When within a few paces from her, the dog stopped, looked in Miss Lney's face, tinen approached her and smelt of her dress, making a circuit around her, after which she placed her nose into the young ladic's hand, exbibiting great satisfaction at making her acquaintaice.

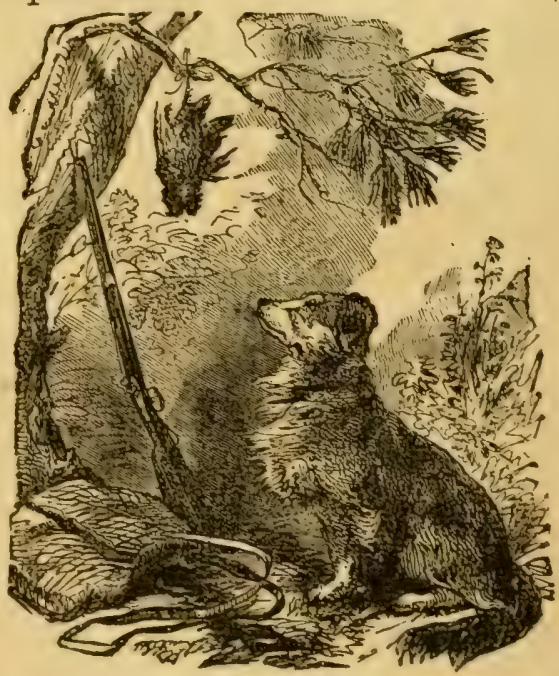




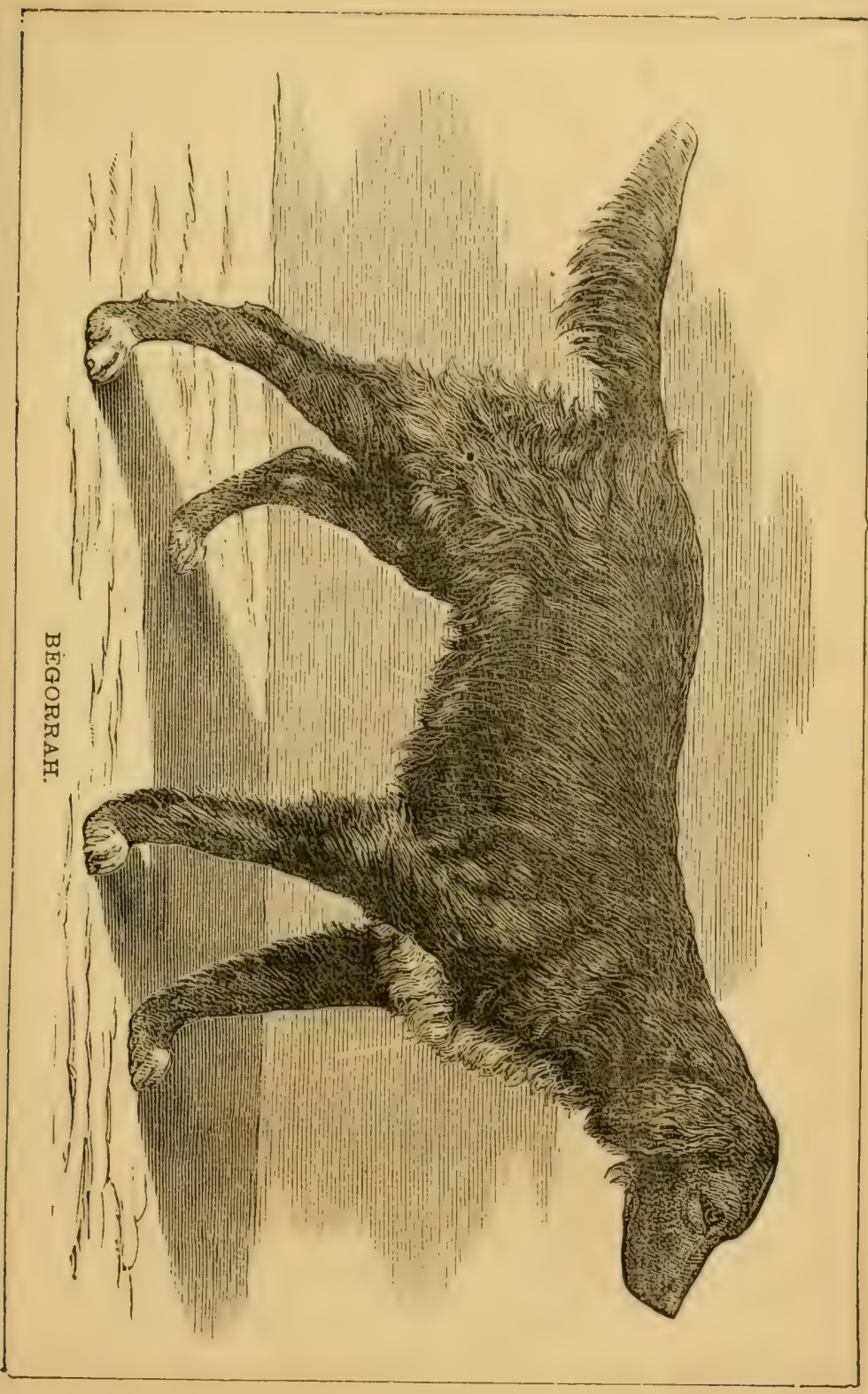




\section{BEGORRAH.}

We give the engraving of the setter "Begorrah," as one of our specimens of the Irish-American Setter. He is a strong, well built setter, with an intelligent head, possessing remarkable strong loins, and is rather more deeply feathered than is represented in the engraving. His color is of a deep red, with white on his breast and twes. Me was bred by Mr. Nicholas Saltus of Brooklyn, and is the property of Mr. P. Noël of New York. Begorrah was very highly commended at the New York bench show, this being the first show at which he was exhibited. He was born in 1876; he is a young dog, but promises much. His sire, the celebrated dog "Plunket," is the winner of 11 prizes won at bench shows and field trials. His grand sires, Macdonas' Grouse and Sultus' Dash, are both prize winners; his great grand sires, on his sire side, Hutchingson Bob and Birtwhistle Tim, are celebrated English prize winners. And no doubt Begorrah, if his owner will give him a chance, will not disgrace his ancestors. We wish him the greatest success. 


\section{DISEASES OF DOGS.}

FeEr,-Sore. - When dogs get their feet sore from travelling, it is common to wash them with brine; but which is an erroneous practice. It is better to bathe them with greasy pot-liquor, milk, or buttermilk, and afterwards to defend them from stones and dirt, by wrapping them up. When the feet become sore from any diseased affection of the claws, the proper treatment may be seen under that head.

Fever.-Simple fever seldom, if ever, exists in dogs. Inflammations of the principal organs of the body, as of the lungs, intestines, kidnies, bladder, \&c., are very common: but pure fever does not occur, except of the specific kind, as the fever of distemper, and the fever of rabies, \&c. \&c.

P1Les.-Dogs are subject to piles, but the symp. toms, by which the complaint shows itself, are by no means known as such, although they are not very dissimilar to the human bremorlhoids. Piles are brought on by confinement, heat, and heating food; and show themselves by a sore red protruded anus, which the dog aggravates by dragging it on the floor. 
$360^{\circ}$

APPENDIX.

Piles are frequently the effect of costiveness. Diarrhoea will also often occasion tenesmus, which may readily be mistaken for piles, the anus appearing red and sore. In such a case, to effect a cure the lonseness must be restrained, and the sore anus may be anointed with the ointment directed below, omitting the tar.

The habitual piles will be greatly relieved by the use of the following ointment:-

Take sugar of lead...........6 grains.

T:r...................... half a dram.

Elder ointment, or fine lard...... 3 drams.

Mix, and anoint the fundament with it two or three times a-day. To keep down the habit towarts the clisease, feed moderately on cooling food, exercise sufficiently, and, as long as the disposition to it is considerable, give daily one of the following powders :-

Nitre, powilered............. half a dram.

Nilk of sulphur.............. 3 drams.

Divide into nine, twelve, or fifteen doses.

\section{FLEAS IN DOGS.}

Arrong the numerous inconveniences to which these valuable animals are liable, I hardiy know one more troublesome to themselves, or vexatious to their owners, than this common 
one of fleas. It is, therefore, a very frequent inquiry made, how they can be destroyed, or how they can be prevented from accumulating? Washing the body well with soap-suds, and directly afterwards carefully combing with a small-toothed comb, are the most ready means of dislodging these nimble gentry. But it must be remembered, that the previous wasl. ing is only to enable the comb more readily to overtake them: the water does not destroy them; for $\operatorname{logs}$, who swim every day, still have fleas. These animals are hardy, and soon recover this temporary drowning; the comb, therefure, is principally to be depended on for their caption before they recover. But as wasbing is not, in many instances, a salutary practice, and in many others is a very inconvenient one, so it becomes a matter of consilerable moment to prevent their accumulation without these means.

Innumerable other means I have tried to drive auray fleas, but the only tolerably certain one I have discoverer, is to make dogs sleep on fresh deal shavings. These suavings may be macie so fine as to be as soft as a down bed; and, if changed every week or fortnight, are the most cleanly and wholesome one that a dog can sleep 
on. But, where this is absolutely impracticable, then rub or dredge the dog's hide, once or twice a week, with very finely powdered rosin; if simply rubbed, add some bran. Fleas are not only troublesome, but, by the irritation they occasion, they produce a tendency to mange.

The realer is referred to the advertisement on page 408, for remedies for various ills with which dogs are afflicted.

\section{CASTRATION.}

It now and then becomes prudent to perform this operation, from disease of the spermatic chord, or from swellings in the testicles themselves. Whenever such a necessity occurs, although it is not a dangerous operation, it requires the assistance of a veterinary, or a human surgeon. Each testicle should be taken out of the scrotum separately, and a ligaturc applied, moderately tight only, around the sper. matic chord, previous to the separation by means of a scalpel or knife.

In performing this operation on cats, nothing more is requisite, than to make a slight opening on each side the scrotum, to slip out the two testicles, and draw then with the fingers. The rupture of the spermatic chord prevents hæm. 
orrbage, and no future inconvenience is felt. It is often found difficult to secure a cat for this overation; hut it may be easily managed in two ways. One is, by putting the head and forequarters of the animal into a boot; the other is managed by roiling her whole body lengthways in several yards of towelling.

\section{FITS.}

The fits that usually appear in dogs, though not very different in appearance from each other, arise from very different causes, and, therefore, require vory different treatment. The epileptic fits that attack dogs of all ages, and and otherwise apparently healthy, may be idiopathic, or they may probably arise from costiveness or worms, \&c. In countries where there are lead mines, dogs have often violent fits from the effeets of the lead on the water. The oxen, sheep, goats and horses, of such situations, also participate. Mercury appesrs to form the best antidote for these contractions, either rubbed externally or given internally.

In the treatment of fits, it is evident that the cause producing them must be attended to, to effect a curs. The immediate fit itself may be 
removed at once usually, by plunging the dog: into cold water; or sprinkling it in his face even, is sufficient in many eases. Whenever a fit has happenerl to a healthy dog, he should immediately have a brisk purge given bim, for tits are very frequently brought on by simple costiveness : and even if such was not the case previous to the fit, this treatment would be the most proper. Should it be at all suspected that the affection arose from worms, treat as directed under that hearl. Some dogs are so irritable, that whatever raises any strong passion in their minds produces an epileptic attack: hence $\log _{\mathrm{g}}$ much confined, on being suffered to run out, frequently bave a fit. It is this irritability in the mind, likewise, that produces fits in pointers and setters when hunting; for they are more frequent in the highbred and eager, than in the cool coarse dog. As a general rule, more frequent exercise should be allowed; and, in this latter instance of sporting dogs, the general constitution should as much as possible be strengthened; for fits are here the effect of too much energy of the mind, beyond the powers of the body : and in all cases they are, probably, the effect of a peculiar debility. The irritability of the mind itself should also be attempted to 
be lessened: in sporting dogs, it is best dome by habituating them to the sight of much game, which greatly lessens their eagerness. For a very valuable dng, belonging to a gentleman in Kent, affected with fits whenever he bunted, I recommended a removal into a country more plentifully supplied with game than his neigh. borhood afforded; the consequence of which was, that though, for a few days after his removal, he had more frequent fits than ever, yet they gradually lessened, and at length wholly leit him. Some dogs, however, who exercise much, have fits merely from the repletion of the head: in this case bleeaing, an occasional purgative, with a seton worn some time in the neck, proves useful: and, whenever fits have become habitual, a seton should be applied, and kept in some months. Fear in irritable dogs produces fits, of which I have seen innumerable instances.

A very distressing and dangerous kind of epileptic fits sometimes attacks bitches while suckling. In these cases it arises from the owners being too anxious to rear several puppies, by which they burthen the mother beyond her powers: the consequence is an attack of convulsions, which too frequently destroys the an- 
imal. Teething in puppies will sometimes produce fits; but some sportsmen, aware of this, fall into another extreme, and consider all the fits of young dogs to originate from this cause: when by far the greater number of these attacks are the effect of worms, or the precursors of distemper.

The fits that are the consequence of distemper, may be usually discovered by the other attendant symptoms: sometimes, however, a fit is the very first symptom, in which case it is remarkable, that the fit augurs nothing unfavourable: but when a fit comes on some time after distemper has made its appearance, the animal seldom recovers. The convulsions accompanying distemper are more frequent in winter than in summer, which shows that warmth is one of the best preventives against these attacks. The convulsion most usually present in distemper begin in the head, and first attacks the muscles of the face and jaws, producing a quick champing of the mouth, with a flow of frothy saliva from the jaws: each succeeding fit is usually stronger and more violent. Another form in which these fits make their appearance in this disease, is, by a running round, with other violent contortions of the 
whole body. In other instances, there is universal and continued spasm of the whole of the exterual muscles, very much resembling St. Vitus's dance. All these varieties are sumetimes blencled, or degenerate into each other:

The idiopathic cpilepsy, or those fits which appear habitual, and not dependent on any temprory eause, as eostiveness, distemper, duc., are, in general, very difficult of cure. In dogs of very full habit, bleeding, emetics, and an oceasional purge, should all be premised. In others, the following medicines may be at once proceeded on :-

Calomel....................12 grains

Powered foxglove ..............12 grains

Powered misletoe............... 2 drams.

Mix, and divide into nine, twelve, or fifteen parcels, according to the size of the ding, and arid give one every morning. After these have been fully tried, in case the attacks do not relax, try the following :-

Lunar caustic, finely powdered......2 grains.

Spiters" web, called cobweb...... . 5 griains

Collserve of roses

sufficient to make nine, twelve, or fitteen bales, according to the size of the dog; of which give one every morning. 


\section{FRACTURES.}

The limbs of dogs are very liable to become fractured ; but irritability of the constitution is so much less in these animals than in ourselves, that they suffer comparatively but little on these occasions: and the parts soon reinstate themselves, even without assistance, though in such cases the limb in general remaius crooked. The thigh is a rery common subject of fracture; and though it appears a most serious bone to break, yet it is one that, with a little assistance, commonly unites straight, and forms a good limb. When a fracture has happened to the thigh, in case the violence has injured the fleshy parts also, so as to produce tension, heat, and inflamation, foment with vinegar and water till the swelling is redueed. When this is effected, apply a plaster of pitch or other adhesive matter, spread on moderately firm leather, sufficiently large to cover the outside of the thigh, and to double a little over the inside of it also. Then attach a long splent upon this, which should reach from the toes, to an inch or two above the back, and will steady the limb very much. This splent must be lept in its situation by a long bandage carefully wound round the 
limb, beginning at the toes, and continuing it up the thigh ; when it must be crossed over the back, consinued down around the other thigh, and then fastened. This would, however, slip over the tail, without other assistance; for which reason it must be kept in its place by means of another slip passerl round the reck and along the back.

Fractures of the shoulder should be treated in a similar manner.

In fractures of fore and hind legs, very great care is necessary to ensure a straight union. As soon as the inflammation and swelling will admit of it (sometimes there is little or none from the first), apply an adhesive plaster neatly and firmly around the part; then fill up the inequalities by tow or lint, so that the limb shall appear of one size throughout, otherwise the points of the joints will be irritable and made sore by the pressure of the splents. After this has been done, apply two three, or four, splents of thin pliable wood before, behind, and on each side of the limb, and secure them in their places by flannel bandage. In all fractures, great caution must be observed not to tighten the part, by either the plaster or bandage, so as to bring on swelling; for, when this has been 
done, inortification has followed. In fiactures of the fore-legs, a supporting bandage, with sirle splents, should be licpt on a longer time than is necessary for fractires of the hinder ones. If this precaution is not observerl, the leg is apt to become gratually crooked, after the apparatus is removed.

In cases of compound fracture, that is, where there is an open wound, which penetrates to the divided bones: the same means must be pursued as are practised in the human subject. Irritating pointed portions must be sawed of ; the looss ones should be romoved; and every uncins must be used to close the wound as early as possible: during which process, the bones should be kept in contacs with cach other, and supported by soft bandages; until the cicatrization of the wound will allow of proper splents and tighter bandaging.

It likewise not unfrequently happens, that a compound fracture, or even a simple one, when neglected, becomes united by a soft union; that is, instead of the callus interposed between the divided ends being bony, it proves cartilaginous only: In such a case the fractured limb never becomes firm; but, on the contrary, when examined, an obscure motion may be felt, like an 
imperfect joint, which utterly precludes any strength in the limb. I bave frequently been consulted on these cases, all of which originated in the neglect of a proper treatment at first.

As a remedy for the evil, one of two practices must be pursued. WTe should either open the skin opposite the fiacture, and, laying bare the bone, should remove the soft portion interposed, with a fine saw, treating the case afterwards as a compound fracture. Or we should insert a seton exactly through the soft cartilaginous portion, and keep it in ten days or a fortnight. After this time it may be removed, the wound closed, and the part treated as a simple fracture. Either of these plans will usually prove successful, and firmly consolidate the limb; but, when there is no lapping over of the ends of the bones, the latter is the most mild and con. venient, and equally certain of success. 


\section{AGE OF DOGS.}

Doggs do not, as horses, present any exact criterion of their age; nevertheless, attention to the following points will materially assist us in determining the matter.

At about four years, the front teeth lose their points, and cach if them preasnts a flattened surfice, which increases as the age advances; they likewise become less white, and more uneven. 'The front teeth suffer earlier than the others, and in dogs fed much on bones, or in those who fetch and carry, as it is called, they are very commonly broken out, while the dog is yet young. The holders, or tushes, are also blunted by the same censes. A scven or eight, the hair about the eyes becomes slightly grey. Gradually, likewise, a greyish tint extends over the face; but it is not till ten, eleven, or twelve years, that the eyes lose their lustre: when they become dim, the dog generally breals fast, though some last fifteen, sixteen, or seventeen years; and I have seen a mother and son vigorous at twenty and twenty one years old. Such instances as the latter must, however, be considered as rare. 
In his native state, perhaps, the dog seldom attains to more than fifteen or sixteeen years, while such as live in confinement and luxury, according to the degree of their artificial habits, become old at twelve or thirteen. Now and then an extraordinary exception occurs: the oldest I ever knew had $\mathrm{r} \in$ ached his twenty-fourth year, and, at the time I saw him, was still vigorous and lively, and neither lame, nor blind, nor deaf. I am not aware that much difference exists between the various breeds, as to the age they arrive at. Spaniels I, however, think rather long-lived; while terriers, on the contrary, I have seldom observed very old.

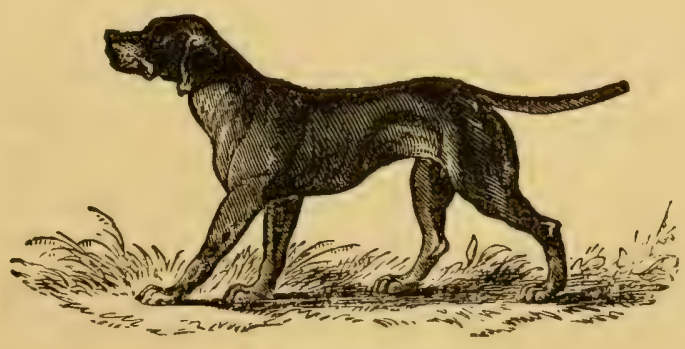


Gravel-Dogs have stone it is certain; that they therefore have gravel also, it is natural to suppose, though it is not always easy to detect it. I have, however, seen the complaint sufficiently well marked. From ten to twenty drops of oil of turpentine, or twice the quanticy of spirits of nitre, twice a day, with a few drops of laucianum added to either in case of much pain, will form the best means of relief.

Husk.-This is the popular term in some countries for distemper; it is also in some others the common name for any cough a dog may have. In Ireland it very communly implies distemper.

WARTS IN Dogs.-It is not uncommon for dogs to be troubled with warts on some parts of the body; the most frequent of which are the lips, the penis, and the prepuce. These excrecences may be cither cut off, or, when they exist in clusters, they may be sprinkled with equal parts of crude sal ammoniac and powdered savine; which commonly effects their removal. 


\section{PULSE.}

From the greater irritability of lesser animals, and the extreme quickness of their circulation, the motions of the heart and arteries, (lo not present such exact criteria of health aud disc sse, as they do in the horse and other large anmals. In cases of very great affection, the action of the heart, and the julsations of the larger arteries, may, however; be felt with propriety, and will serve as some guide to ascertain the degree of disense. The pulsations will not only be increased in quickness, but will present a vibratory feel in viulent inflammatory affections. In inflammations of the lungs they will be very quick and small, but will increase in fulness as the blood flows during bleeding. Something like the same will occur, but not in an equal degree, in inflammations of the stomach and bowels also. As the pulsatory motions, therefore, are not so distinct in the $d \log ^{2}$ as they are in larger animals; so, in general, the state of the breathing, which, in most cases, is regulated by the circulation, may be principally attended to as a mark of greater or less inflammatory action. When a dog, therefore, pants violently, his circulation, or in other words his pulse, may be considered as quickened. 


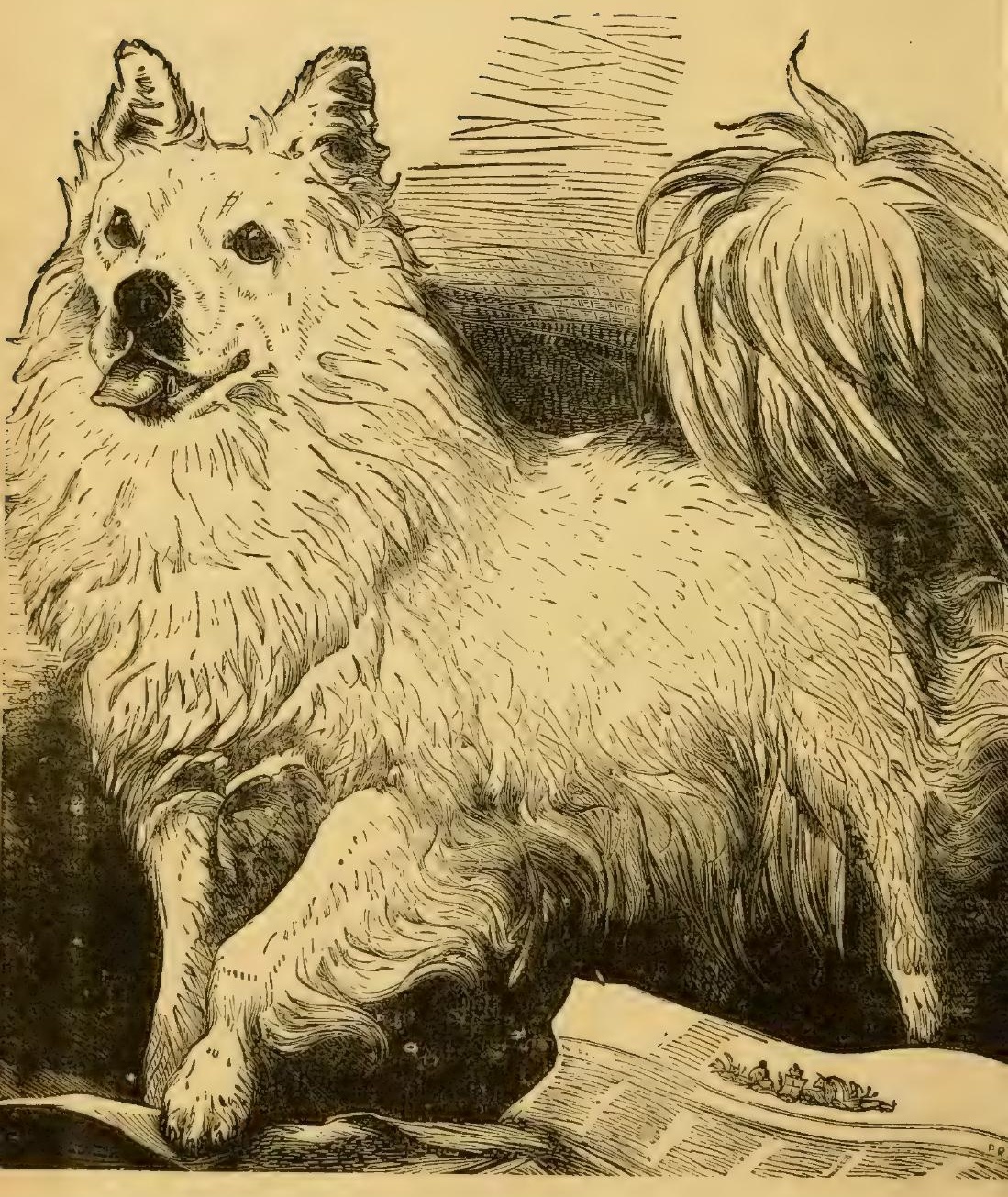




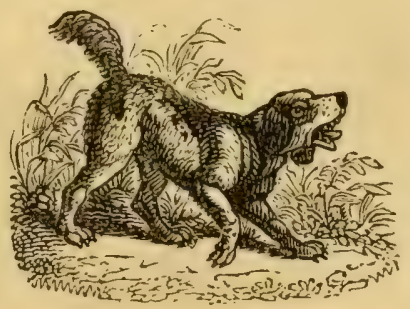

\section{HYDROPHOBIA-THE SPITZ.}

This is the most important sulject at present before the public, and is discussed pro and con by both the learned and unlearned. There are many deaths charged to the bite of the Spitz, who is accused of being a snappish dng, and over fond of using his teeth. But the Spitz has his friends, and will not be made a scape-goat. of for all the other dogs. Fortunately for him, most of the recent cases of hydrophobia have becn caused by the bite of dogs of another species. His enemies retort, that this does not clear the Spitz from being the cause, as the cur may hawe been inoculated with the poison, by the bite of a Spitz.

Ex-Surgeon General of the Army, Dr. Wm. A. II:ummond, who is regarded as one of the most eminent anthorities on nervous disenses in this country, gives his views on hydrophobia, 
which is now conceded to be a nervous disease. The Doctor concurs in the dangerous nature of the Spitz dog, and considers theory of the harmlessness of the Spitz absurd.

IIe says Spitz dogs are more prone to excite hydrophobia in the human system than any other breed of dogs his knows of, and pronounces the Spitz a cross between the Pommeranian hound and the Aretic fox. All hybrids are bad. While the blending of varieties is good, that of genera is accompanied with evil results. The disease can only be communicated by the saliva or by a wound, and not by the injection of the blood of the hydrophobic anima!. The saliva is the only poisonous part of animals. The Saliva of the rattlesnake will kill you, and yet you can eat the rattlesnake.

Until more comprehensive investigation settles the question, we are justified in assuming from our present experience that the saliva of the Splitz dog is more uniformly poisoncus than that of any other dog, and experience teaches that the saliva of a dog not suffering from rabies may be poisonous under certain conditionswhen the dog is in a state of anger or fury or merely in a condition of excitement.

Dr. Hammond says the Spitz is absolutely of 
no use, and in a matter involving precious lives, it is better to be ou the sufe side. Nothing would be lost by exterminating the Spitz.

A dog perfectly heilthy, says Dr. IIammonrl, or at least free from rabies, may produce the disease by his bite through his saliva. In the case of MIcCormick the dog was exlibited to the Neurological Socicty more than a month after the bite, and as hydrophobia rums its course in seven or eight days, and as the doginvarial)ly dies, he either could not have had it or he could not have been the dog in yuestion: remember, it takes a wound to procluce death. You might swallow the saliva and it would not kill you unless you had, perhaps, an abrasion on your lip. The salive is only poisnnous when communicated through a wound. You get lockjaw, or tetanus, from a simple wound, and hydrophobia seems to be tetanus plus a group of other symptoms.

We can recognize the origin and symptoms of hydrophobia as we can those of scarlet fever or measles. To this day no one has discovered the primal origin of scarlet fever. We know that we cannot cure hydrophobia. Remember that there never has been a cure on record. It is necessary not to confound the prevention with 
APPENDIX.

the cure. There are a great many people who claim to have invented cures for hydrophobia, but they mean cures after the bite and before the poison has been developed. This is an easy matter, but no cure has as yet been effected after the poison (which lies dormant in the system a few wecks, and sometimes even several months, and even several years) has been developed. In the early part of last fall a distinguished officer of the army came to me, who lat been bitten by a dog, manifestly hydrophobic. I cauterized the wound with a red hot iron, and I regard him as perfectly safe.

Dr. Hammond seems to be well sustained in his assertion that there is no cure for hydrophobia after it has permeated the system, but prevention is tried with a great deal of faith. Nevertbeless in almost every ease of hytrophobia that has occurred of late, the parts bitten had been cauterized. But whether with hot iron, as Dr. Hammond recommends, or with caustic, we are unable to say. Any other preventative will be eagerly sought after by the public. Dr. Blaine, (formerly Blaine \& Youatt, the celebrated Veterinary Surgeons, recommended excising the wound. Immediate cxeision or cauterization was not considered abso. 
APPENDIX.

lutely necessary, although the sooner the better. Dr. Blaine also used an internal remedy, in which he had great f:ith, laving administered it several hundred times, with less than a dozen failures of immunity. In all cases of failure, the bites were on the head.

Where a human life was at stake, he also cut out the bitten part, unless the patient strongly objected to the severe treatment. Below will be found the formula for Dr. Blaine's preventative.

"Take of the fresh leaves of the Tree Box, 2 ounces, fresh leaves of Rue, 2 ounces, Sage Lalf an ounce, chop finely, boil in pint of water till rerluced to half a pint; strain and press out the liquor. Beat in a mortar, or otherwise thoroughly bruise, and boil in pint of new milk, to half a pint, which press ont as before. Both fluids to be rnixed, and livided into three doses, and taken, one every morning on a empty stomach. Double this quantity would be requirer for a horse; one third for a small dog; and half to two thirds for a large one, or other small animals. It is undoubtedly a hard dose to take and retain, and would never become "popular," unless there was unbounded faith 
that it was the only remedy agaiust the dreaded and fatal disease.

Some years since, it was stated that steam bath was a remedy for hydrophobia, and had been used with success. But, like many other remedies, it was found not to be infallible. It is again recommended with great coufidence, as an auxiliary in preventiug and curing. Hydrophobia, it is said by some, is located in the stomach, and the treaiment should be that which has a tendency to throw the foul matter from it. $\Lambda$ course of Thomsonion treatment is reeommended for this. No. 6 and skinlleap, steeper in milk, and in cases where symptoms of hydrophobia are shown, and fluids can not be administered, enemas of lobelia and valerian are to be administered, which wiil cause the foul matter to be thrown from the stomach, relax the muscles and relieve from spasms. This treatment, with steam baths, must be followed for several weaks. For a week or two daily, and two or three times a week afterwards.

Only experience can prove the efficacy of this as a remedy. But, as the most skilled physicians make no preteusions to a remedy when cnce attacked, and only cauterization as a prerentative, nothing is rislied in resorting to this 
course of troatment possibly it may lead to happy results.

It is well to always avoid dogs or cats, which act strangely, or endeavor to conceal themself in dark or secluded corners. That is a sign of illuess in almost erery species of the brute creature. Guarding against bites of the Spitz and diseased dogs of all descriptions, is certaiuly the best preventative.

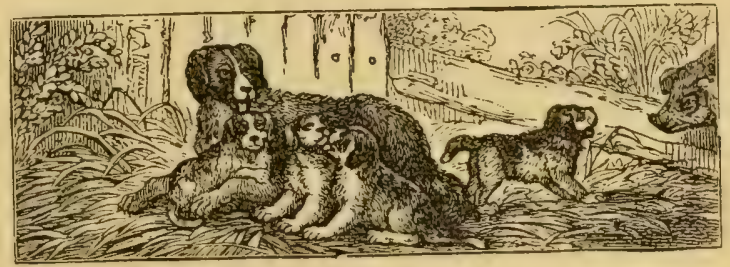




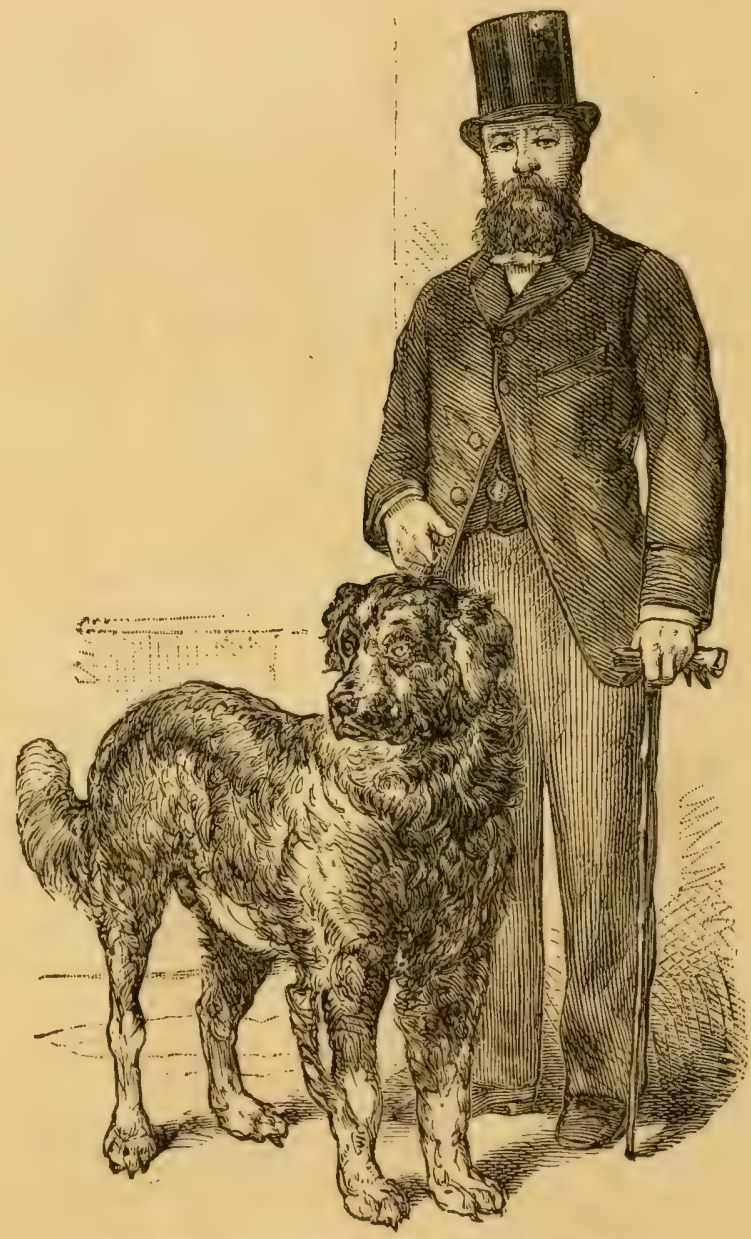

THE REV. MR. MACDONNA, WITI HIS DOG " MUNGO." 


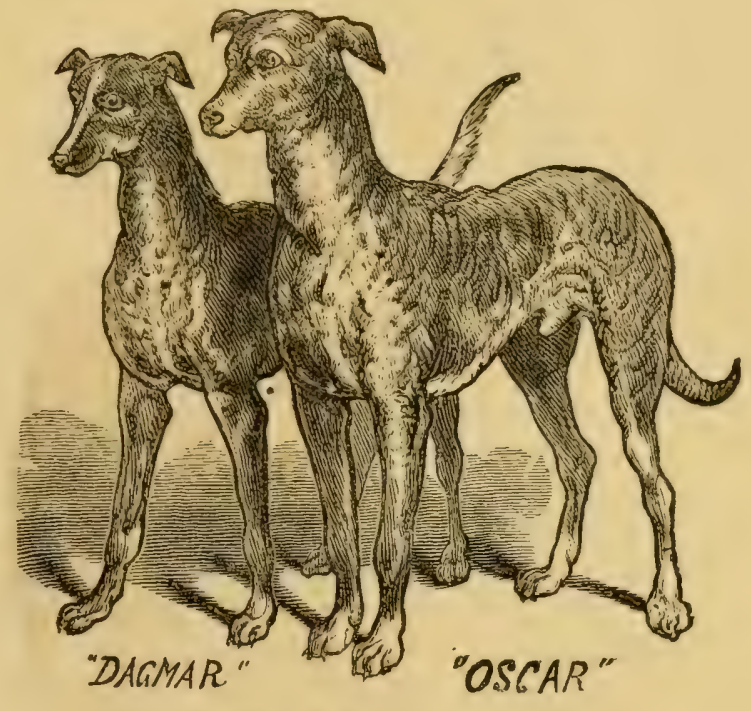

QUEEN VICTORIA'S DEER-HOUNDS,

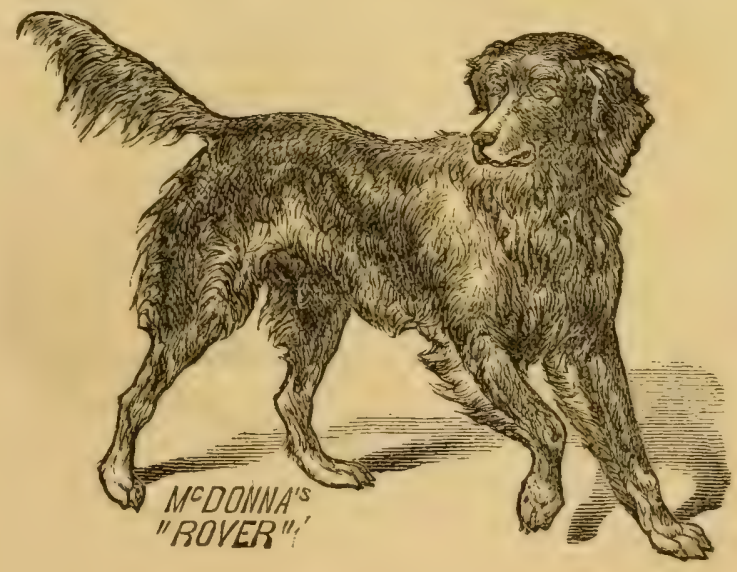




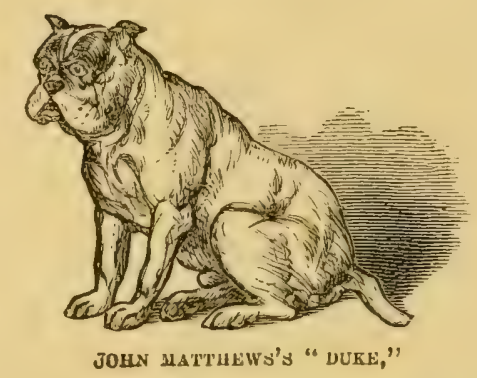

THE GREAT BENCH SHOW

IV as held in the Hippodrome, which had been fitted up expressly for the purpose. Stalls were erectel around the capacious arena for the accormmodation of the dogs; but the entries were so much in excess of the calculations that extru stalls were built, at the last moment, insicle the arena. There were also two rings into which the sevcral classes of dogs were taken to be judged.

The show opened Tuesday, May 8t!. As early as ten o'clock Mondily the dogs began to arrive. 'They came by all sorts of conveyances. Some were packed in huge coops marked "with care," others were led by stout iron chains, and still otiners were carried in baskets or in the arms of their owners. Among those bringing their pets for exhibition were many elegantly 
dressed ladies. Crowds of men and boys surrounded the entrarice. Some of the logs were disposed to be quarrelsome, especially the big fellows, and many times the crowd scittered with ludicrous haste at the unexpected growl of some ferocious-looking brute. There was danger from some of them, too, for their owners took great care to keep them at a safe distance from the legs of imprudent bystanders. Not a few had great difliculty in holding the powerful animals in. Other dogs were quiet and friendly, but not less annoying to their masters by plunging about and entangling their chains in seemingly inextricable confusion.

The spectacle inside the arena, when every thing was in readiness, was very attractive. There were over eleven hundred entries of all classes, from the huge Siberian blood-hound, the magnificent St. Bernard dog, the Newfoundland and the mastiff, down to the most delicate toy dogs. To the latter were devoted several stands in the centre of the arena, and this was one of the most attractive spots in the show. The little things were rigred up with ribbons, mats, cushions, bells, and lace collars, in the most dainty style. Two large pups with lace collars were very amusing. Others were the 
occupants of a 31 mber of maliogany-framed glass cases. One of these, a tiny mite of a thing, with long silken luir, bore the ferocious name of "Danger:" There were also three beantiful Italian greyhound puppies, five rlelicate Japanese puppies, and six little white balls nestling under their Blenheim spaniel mother.

'The principal attendance was during the evenings, when the building was crowded to its full capacity. There were quite as many ladies as gentlemen present, and they seemed to take quite as much interest in the dogs. The only drawback to the enjoyment of the show was the creadful howling that tilled the building and at times almost prevented conversation. Mr. BerGH's speech on 'Tuesday evening was inaudible six feet from where he stood. The larger dogs were, as a rule, dignified and quiet; but the petted dlarlings of the drawing-room expressed their anguish over their imprisonment and loss of home luxuries in tones that must have pierced the very hearts of their fair ownel's.

The show was in every sense a great suceess, and will probably prove to be the first of a long series of such exhibitions. It was held under the auspices of the Westminster Kennel Club, 
and for a first enterprise of the lind, the man. agement was noticeally free fiom amoyances and mistakes. It lasted four days, and every one who visited it was delighted and entertained. But if the question of bolding another bench show were left to the dogs, it would doubtless be rejected by a large majority.

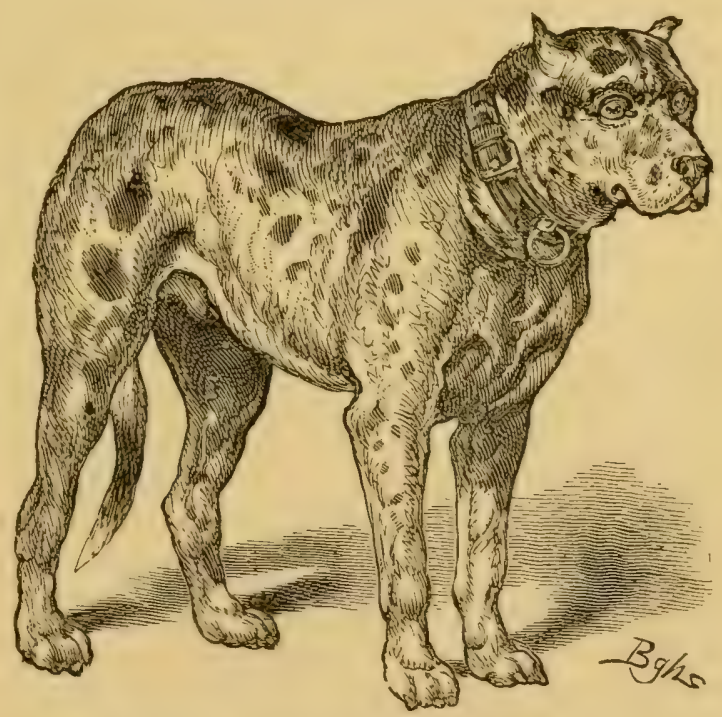

STR. JONES'S SIBERIAN BI,OODHOUND "BRUNO." 


\section{THE BONES OF THE CANINE SKELETON.}

The first portion of the skeleton which claims our attention is the skull. The shape of this extremity is fumiliar to every one, and differs in the virious breeds, being more elongated in the greylound, for instance, than in the Bulldog or Newfoundland, where it forms al well-roumled dome, with a wide cranial cavity, or brain-pan. All that it is necessary for the reader to note is -

The General Configuration of the Skull and its different shapes according to breed, bearing in mind that nearly all the breeds are well developed as regards brain-pan.

The Nasul Bone, well developed in the dog.

The Occipital Bone, also well developed. This portion of the dor's head is called the occiput.

The Orbital Cavity of the Eye.

The Superior Maxilla, or upper jaw.

The Inferior Mfaxilla, or lower jaw. The teelh of the two jaws in the majority of breeds ought to meet evenly in front; in other breeds, as the Bull, the King Charles', \&c., the under jaw projects more or less.

The Teeth.-Unlike the cat, who has to be content with thirty teeth, the dog is liberally supplied with these useful weapons, having, when full-srown, forty-two-riz., 12 incisors, 4 canine or tusks, and 26 molars; 20 teeth in the upper, and 22 in the lower jaw.

Dogs begin to get their first or milk teeth at a month old, and the pemanent teeth ought to be all perfect when the animal is six and a lalf months oll.

The Temporal Bone, more prominent in some $\operatorname{logs}$ than in others.

We next come to the Vertelıral Column. This column or spine is designed by Nature for the protection of the nerrous spinal column, a continuation of the brain matter. 
From this column nerves escape by foramina through the vertelore, to be distributed to all the various organs, mus cles, and bones of the body. The vertebral column is also a support to the limbs and the whole osseous system. The spine is composed of small round perforated bones called vertebra, beautifully hinged together. They are divided into-

The Seren Cervical Vertehre, corresponding to the neck of the animal.

The Thirteen Dorsal Vertebra-the back.

The Seven Lumbar Verlebra-the loin.

The Three Sacral Vertebra, forming a portion of the pelvis, and

The Caudal Vertebro, forming the bones of the tail, or stern, and numbering (if left alone) from 16 to 21 .

The os innominatum is the principal bone of the pelvis. Hinged to this by a ball and socket joint is

The Femur-the thigh-bone--a long, sturdy, and strong bone, jointed by its lower extremity to three bones, namely--

The Putellu, or kuee-pan; and

The Tibia, which gives its chief support to the patella, and is the principal bone of the ley or hock, is, like the femur, a long, strong bone, but differently shaped. The other bone of the leg is

The Fibulx, a much more slender bone, situated on the outer portion of the tibia, and joined to that bone liy a strong fibrous tissue.

The Bones of the Hock Joint.

The Foot Proper, commencing at the hock joint, comprises the calcaneus-or heel-bone-the astragalus, the schaphoid, three cuneiform bones; five metatarsal bonesthe lougest bones in the foot (one of these metatursals is 


\section{4}

APPENDIX.

only rudimentary ); and the first, second, and third phalanges, ending in the naiis.

The ribs of the dog are in number thirteen at each side. They are articulated to the vertebre above and partly to the sternum, or to ench other beneath. The rilss of nearly all classes of well-bred dogs ought to be well slurung.

The Sternum, or breast-bone, is a flattish or scimitarshaped bone, composed of several pieces joined together, and lying underneath the ribs, at the lower portion of the chest. It neecis little further description here.

The shoulder in the dogr is composed of two bones, the Clivicle and the Scapula. The former of these barely needs mention, so unimportant and rulimentary is it.

The Scapula or shoulder-blite is a much more important bone. It is fiat, broad, and moderately strong. especially towards its lower. portion, where it articulates with the humerus. Its shape can be seen from a glance at the illustration. In most dogrs, especially sporting dogs, this hone should slope well backwards. On the onter surface a strong bony ridge descends for the attachment of the muscles.

The Humerus is the one single bone of the arin. It is a long hone, very strong, and somewhat bent or curved.

The bones of the forearms are two, namely-

The Radius, and

The Ulna. In the human being the radius is much the stronger bone, and the two lie parallel. In the dog the two bones are about equal in size, the uha being thicker at its upper portion, and the radius stronger at its lower. Again, the bones are not per.ectly parallel, but slightly, or in a very small degree, positioned like a St. Andrew's cross. These two bones are hinged to each other at the upper and lower surfaces.

From the lower portion of these two bones the forefoot proper commences, comprising the following bones, viz.- 
Seren carpal bones, corresponding to the busuan wristbones, five metacarpal bones, corresponding to the bones joining the wrist to the fingers in the human suligect (the bones that are in the back of the haud), and the tive digits or fingers, which in the dog are analogous to those of the human skelesols. Each digit is composed of three columuar bones. Lastly, they are nited at their extremities to the nails, which grow therefrom.

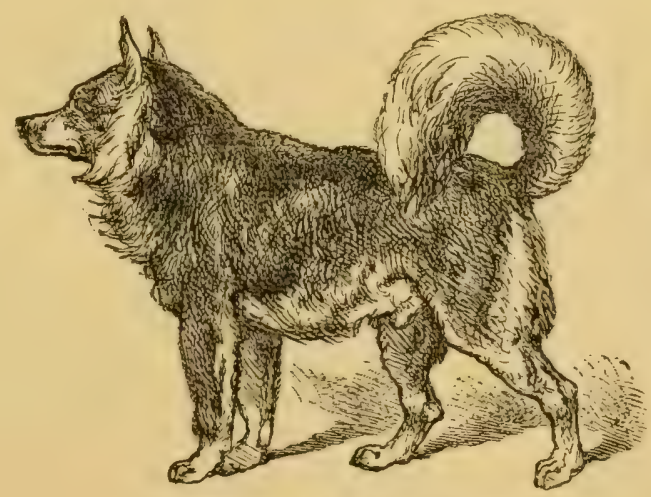

TIK ONLT ESQUIHAUX IN TAE SROS. 


\section{GLOSSARY OF WORDS USED BY THE FANCY.}

A PPL j-IIEADED. - A term usell to desigmate the peculiar romulntes of the black and-tan Toy Terrier. This roumbness is consiciered a point of beaty ly some judges.

Bentoss (Blue and Lemon ).-The spotted or flecked Laverack Setter.

BABBLER.-A dog that gives too much tongue when workin!. Generally applied to those Spaniels which ought to be miate.

Broody. - A broody bitch-one that, foom its leneth and confomation, gives evidence of being a likely mother.

BLOOD. - A blood - a log with every appearance of high breeding.

BrJsiser. - The chest- of a Setter, for instance.

Buazis. - The white hue up the fuce of some lureeds, such as the St. Beruarl, Scotch Collie, or Blenheim.

Butron-Ear. - A term used to define the peculiar shape of some Bullclogs' ears.

Braque.-A German name given to a D.hishund of anusual size.

CAT-Footed. - Having a foot like a cat-the ortholox foot for Greyhounds and nearly all other clous.

Consy. - $\Delta$ u $+x$ pression used in descrithing some Fox Terriers, with reference to their symmetry and well-knit appearance.

Cosdrton. - A dog's heing in condition means that he is in: a st:ate of perfect health: just enough tlesh, and no more, aurl lis coit in excellent orler.

Character. - When a dog shows character, he slows in a marked manner the points of the breed to which he belones.

Crest.-The upper rilge or portion of a clog's neck. Generally applied to sporting doens, is the Setter.

Comb Fmasc - The beatiful stritght fringe of feather that ciroops from the tail of it Setter.

DEwhaP.--. That portion of loose skin that hangs from the throat of some dogs, as the Bloollomme and Bullelog.

DEwchaw. - An extra claw found on the insile of the lower portion of the hind leg of many lows. especinlly the St. Bernarl. where it is admissible. In the Newfomilam it is not, but it is often seen on the Scotch Collie. It is ns- 
ually cut of when fouml in puppies where its presence would not enhance, or would spoul them for show purposes.

FAkixg.--Interferiug with a dog's nutural appearance for the sake of hiding defects. as dyeing a Retriever's lorenst. if white; or pullim the flas, if any, from a curly-coated Retriever's tail. "A Fake" is the deed done.

FLETs.-The chitps or hanging lips of a dog, as the Bloodhound.

finl. - The beantiful half-crescentic muss of feather under a Scotch Collie's tirrout.

FLdG. - A term applied to the drooping feather on some dous' tails, as that of the flat-costed Retriever.

Frather. - A word used to clescribe the long hair and locks in a dogy's cont, and the coat of long-haired dogs grener:ally.

FIDDLE-HEADED. - A very expressive term, used to define the lintern j:ws of some big bidly-bred Mistifis.

FELTED. - When the lonir fenther of a Collie or Retriever gets mitted into masses that hit ilefiace to anyhing short of scissors, it is said to be "felted," a condition which is a disurice to the dog's owner.

Fixed.-Means astonished. Judges are fixed by some particularly and rarely bred dogs.

HARE-FOOT.--Sjnoliymous with spoon-foot: defining tha shape of foot some dogs have, as the Pug, which has the toes well split up, as in the hare.

Horer.-- The hed or nest, of the otter, generally built of striw or stublule, withered sriss, and weeds, in a hollow of bauk or rock by the river-site.

HAw. - The reldish portion of the inner eyelid of the dog, shown in the Otterhound, Bloothomal. and St. Bernari.

Kissing-spots. - The spots on the cheeks of some Toys and other's; as the mole on the cheek of the I'uy.

LANDSEER. - A name given by the author, and now generally adoptei, to the great white-and-black Newfoundland, which the immortal painter so loved to portray.

Lippy, - Applied to hanging lips of some dogs where hanging lips should not exist, as in the Bull Terrier.

Lingthy. - Possessing length of hody, as the Newfoundland ougl.t to do. A Slije is long, a Newfoundland or St. Bernarid lengthy.

Leather. - The skin. Especially applied to the dog's ear. 
LANY Pack.-Hoanits are mstally hnted in fracks all of oue sex. The bitches are called the "t baly pack."

LEVEL - A term used to deseribe some fox-terriers. A fors teeth are said to be level when the jaws are neither overhung nor underhmg. You cammot put your mail behind a tooth when the month is closed.

LEGGY.-Having the legs too loug in proportion to the boly. "Shaped like a milking-stool," (Idstone).

MANE.-The feather which is massed on the shonhers of the Collie aud Newfoundland. That ou the breast of the Blenheim is also called the "mane," which is quile a sabversiou of the term.

Massivenfss. - A term applied to the body of a good Nertfotudland or St. Bernard, and Glescriptive of the solidity of frimme.

Pasterns.-The antles.

PIG-JAwED. Haxing jat in the formation of a pig. Applied to Setters when the upper juw protrules.

l'EAKED. - A word used to dlefine the formation of some tous' craniums, as thut of the Blookhound and Irish Setter.

PILEx. - Appined to the coats of some dogs, as the Dimile. signifying that the eoat is a mixture of harlish and solt hair.

PENCrlued Toes. - The toes of a well-bred black-and-tan Terrier are "pencilled," or marked with black apon the upper or convex yortion. A point of beauty.

Pintrire - Descriptive of the coats of some Terriers.

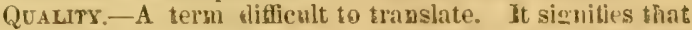
mixture of blood and breediness that rou see in may goon dous, notably sporting toos. It is seeu in shape, and coat, and eye. and delicacy of form. \&c.

Rins-TAIbED... The word tells its own tale. It is seen in the tails of some Deerhousds.

ROSE-EAR. - Another form of ear of Balliog. This ear "fohls at the back, and the tip laps orer outwarls. showing part of the inside," (Idstone).

STERr. - The tril. Mostly used in sporting parlance.

SirfLF. - The joint next the battock.

STOcKY.-A bitch is called stocky when she looks as if she conld throw good paps and be a crood mother.

Srop.-The hollow or indentation bet ween the eyes of some lireeds. as the Bulldog, the King Charles, \&c.

Srixt.-A dog's thil is stiug-like when it is broat at the 
base aml tilpers to a fue point, as in the well-bred Pointer. SLuT. - Bibeh, ur lady-log. Not often used.

SNIPEY. - A dug's Liuzzie, when loky, husrow, ard jeabed, is so designated.

SNAPNOG, of IVHIPET. - A kind of small Greylrotrm, nsed in some countries for rabuit-cotrsiner.

Setwitar or SABBE CURVE_-Wurls used to detiue the correct carriage in the tixil of the Setter.

Throntisess. - Loastuess of the shim of the throat, or dewlap. Quite con'ect in the Bulklor and bichshum, for example, but intolevible in the Pointer.

Toxgue - Equivalent to voice.

TULP-EAR - Purty priclied. and droopirg at the tip.

THUAB-XARK. - An ohliquely-shapel black mark croszing the foot of a well-bred Black-ind-tan above the toes.

TignT-LIPPED-Haviug no tlew; as in the tighting Bubani-termer Dog.

WEEDY. - A very expressive word, as applied to a dog

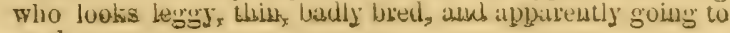
seed

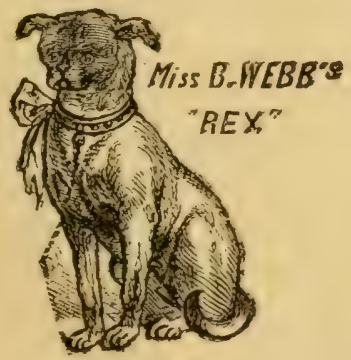




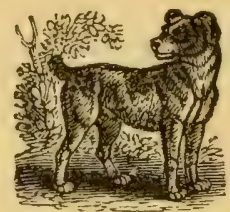

RULES AND REGULATIONS

OF THE

\section{WESTMINSTER KENNEL CLUB.}

No dog belonging to the Westminster Kennel Club, or to any member thereof, will be entered for premium, although all will be on exhibition.

This Bench Show will be held under the rules adopted by the National American Kennel Club, as

Ruis 1. Every person who wishes to exhibit at any show held under these Rules, must at the time of entry clearly identify by name and age (if known) the dog he intends to exhibit, and the name of the sire and dam (if known) must be given. If the name of a dog has been changed it is necessary in entering the said dog to give his old as well as his new name.

Rule 2. If a dog shall be entered without being clearly identified as directed in Rule 1, he shall forfeit any prize that may have been awarded him, and if the omission be detected in time he shall not be allowed to compete, and 
shall forfeit all entrance fees and subscriptions.

RuLE 3. The committee or authorities of any show held under the Kennel Club Rulus, may reserve to themselves the right to exclude any dog or dogs belonging to any person who has been proved, to the satisfaction of the committee of the Club, to have misconducted himself, in any way, in commection with dogs, dogshows or dog-trials.

Rule 4. No dog shall be qualified to compete, or entitled to receive a prize, if awarded, who is suffering from mange, or any other form of contagious disease.

Rule 5. $\Lambda$ person, rluly qualified, appointed by the committee, shall rlecide whether a dug is, or is not, suffering from mange or any other contagious discase, and shall give lis opinion immediately to the secretary, or committee of the show, in writing, and if found to be afflicter with any such disease, the dog shall be at once removed.

Rule 6. A dog that has been exhibited or has won a prize in a class cxclusively for puppies under twelve months old, is not thereby excluded from being exhibited in a class where previous prize winners are not allowed to compete. 
RuLE 7. All imported dogs and their progeny on both sides (but not the progeny of the latter) shall be entered in the imported class, and be debarred from entering in the native elass; but no native dog shall be debarred from entering in the imported class.

Rule 8. Dogs are to be judged by the scale of points used at recent bench shows and copied from the Fanciers' Gazette.

In arddition to the above, the following Rules and Regulations will be strictly enforced:

1.-All judging will be done in public on a raised stand prepared for the purpose, and collars bearing owners' names will be removed or covered before the dogs are brought before the judges.

2.- - n entry fee of $\$ 2$ will be charged for each animal entered. The entry fec must in ail rases accompany the entry. Entries will be received until noon on $A_{\text {pril }} 25$ th, except in case of foreign exhibitors, who will be allowed until May 1st. Dogs must be at the Madison A renue entrance of the Garden by 8 o'clock on the morning of Tueslay, May 8th, but it is earnestly requested that when possible all dogs will be on hand on Monday, the 7th. The entrance fee will include care and feed of dogs. 
3.-It is required that a price-be named for each dog at the time of making the entry to be printed in the catalogue, at which price the dog may be claimed; the exhibitor, of course, haring the option of naming a prohibito:y price. A commission of 10 per cent. will be charged on all sales. and the sams must be effected through the Secretary or Superintendent.

4.-All entries must be made on blanks furnished by the Club, which can be had from the Suparintendent by addressing him at his office, No. 17 Chatham Street; ( P. O. Box 2832.)

5.-The anthorities will use due diligence for the care and safety of all dogs exhibited (watehmen being on duty both night and day,) bu; it must be distinctly understood that they will not be responsible for loss of or clamage to any dog exhibited, whether the result of aceident or any other cause.

6.-The pedigree of all dogs entered is desired, although not actually required, except in case two dogs in same class should be so nearly equal that judges cannot agree which is the best. In such case if one has an authenticated pedigree and the other has not, the premium will be given to the dog with the pedigree.

7.-The decision of judges will be final in 
all cases, unless misrepresentation or collusion can be shown-should this occur the Executive Committee will use their discretion in the matter. Allowance will be made for dogs that have been worked this season, and no deduction will be made for docked tails or ears.

8.-Judges will be instructed to withhold the prizes offered in any class where there is no competition, unless the animal exhibited possesses suitable merit, in which case their discretion shall govern the prize to be awarded, either first or secoril, and they will then be instructed to withlıold prizes where the dogs do not come up to the propar standard of merit.

9.-Exhibitors will be permitted to take home their dogs every evening after the show is closed upon leaving a deposit of Five Dollars with the check clerk and surrendering their entry tickets, both of which will be returned on the re-producing of the dog in tive morning before 10 o'clock. If prize winners should be taken out and not returnerl the prizes will be forfeited.

10. - Exhibitors need not accompany their dogs. They can be sent direct to the exhibition hall, and direction cards, printed for this purpose, will be furnished by the secretary. All dogs will be promptly returned to their owners 
APPENDIX.

at the close of the exhibition, or otherwise disposed of as they may direct.

11. -The show will be open from 10 A. M. to 10 P. M. The judging will be done on the first day, and the ribbons will be attached to the stalls of the winners immediately therealter.

12.-The prizes, which will be in gold coin for the several classes except Champions, will be presented in public on the evening of May 10th, at 9 P. M

13. -The term dog or bitch implies that the animal is over one year old. The age of it must be computed from the date of birth up to the 8th of May.

14. $\rightarrow$-Railway Arrangements. Arrangements for the free transportution of dogs are in course of completion with all Railway Companies cen. tering in New York, and will be duly announced.

15. - The members of the Committee will be in constant attention, and especial attention will be given to the care of pet dogs.

16. -Judges will be instructed to give the awards of Highly commended and Commended where in their option it is warranted.

17. - No dog will be received unless supplied with suitable chain and collar. Bitches with 
pup and smali pups weaned, will have suitable pens provided. Toy dogs will be furnished with suitable cages.

18. - Exhibitors residing abroad may ship their dogs to the care of the Westminstel Kennel Club. If for sale, certificate from the American Consul at the port of shipment that they are exported for breeding purposes must accompang them. If to be returned, the Club will give a bond to the Custom House authorities.

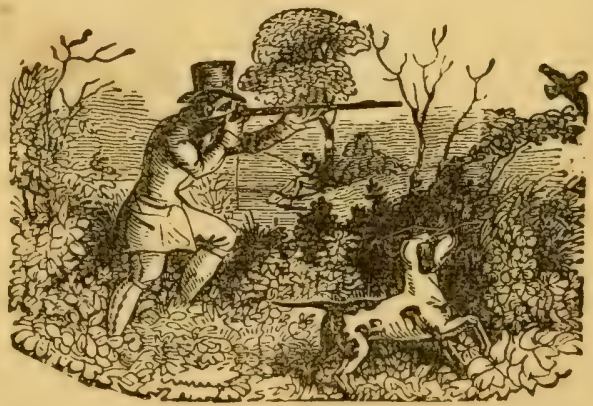




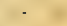

-

$-$ 


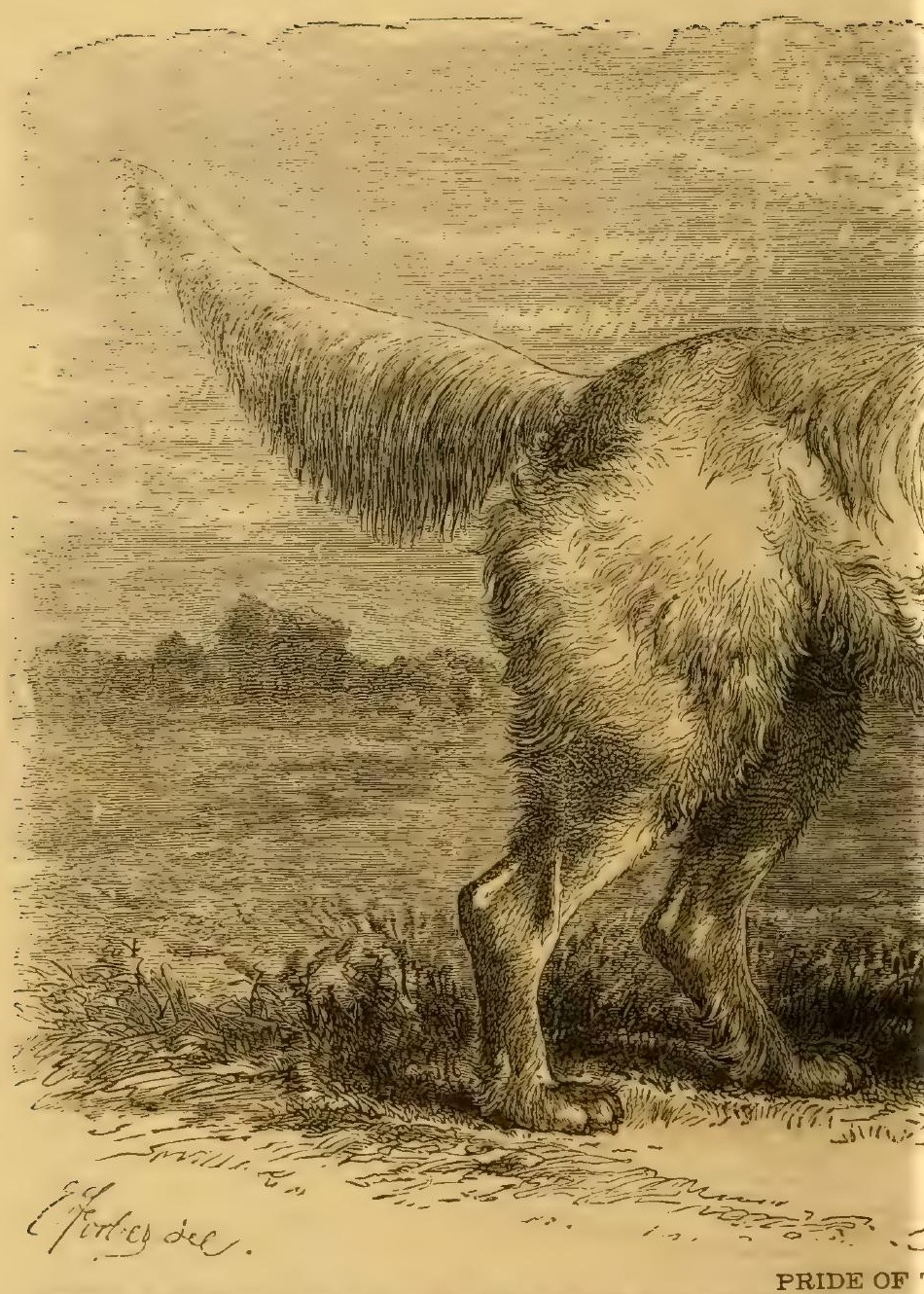

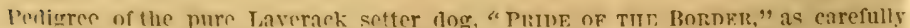
liroughal: Coftage, Whitehurch. Shropushire. Fingland. Imported in $18 \mathrm{~s}$ t, hy his present ings, and is sire of Mr. Javerach's celehrated Stock and Fipld Dog. Jihe Prince; Mr. l, Manchester: Mr. Dicken's Blue Dash, and of many other highly valued Setters.

fox Farm, Mozkis plains, N. J. 


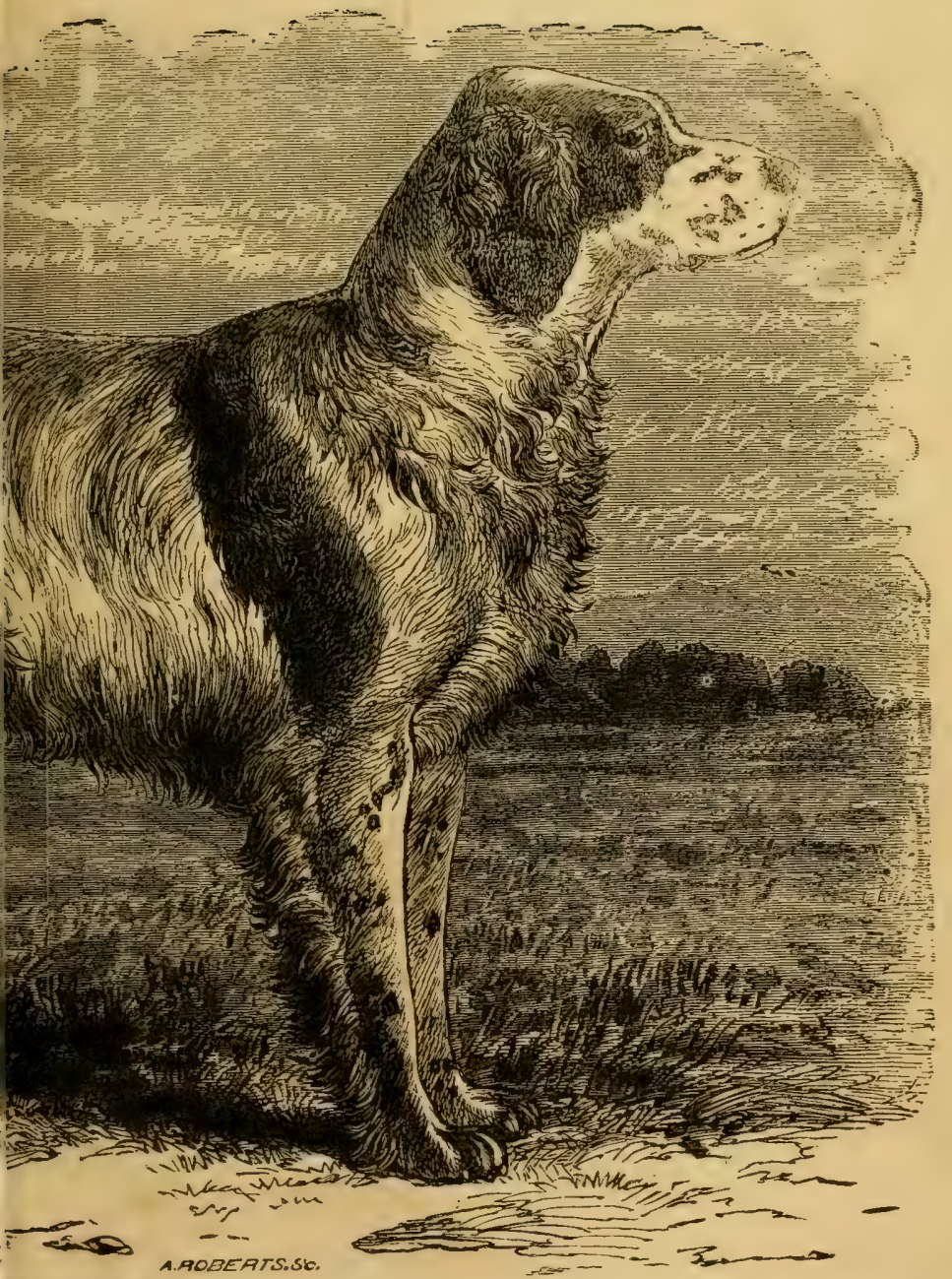

E BORDER.

ected by Mr. Laverack, under date of March 31st, 1875. Bred in 1869. by Mr. Laverack, ner. Mr. Charies H. Raymond. PRIMF OF TIE BoBDER is a white dog, with liver markner. Mr. Charies H. Raymond. PRIns oF THF Boter, prize winners at Birmingham and

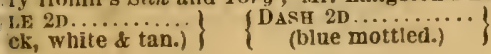



WXy

4)

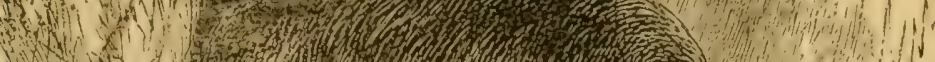

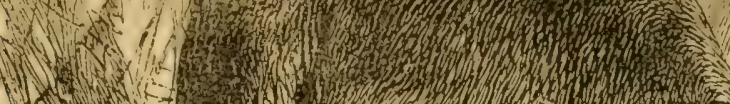

H.1.1.

(I)

630

101 (n)

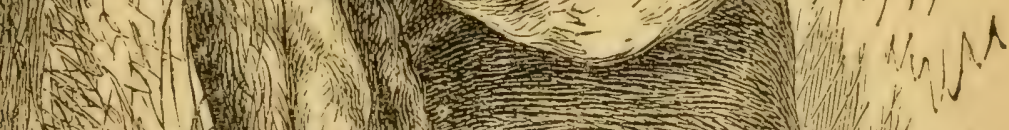

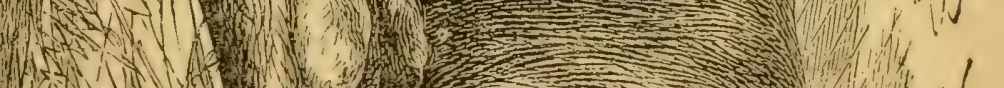

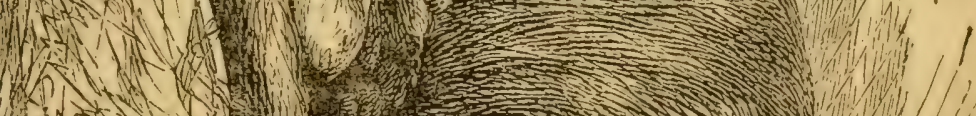

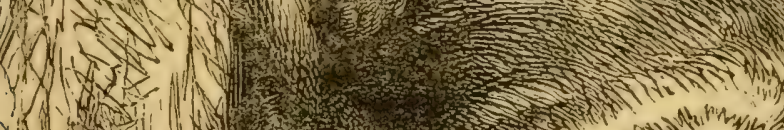

Y

(1)

-

$<1 / 1$

vin 140

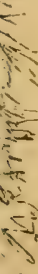

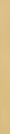

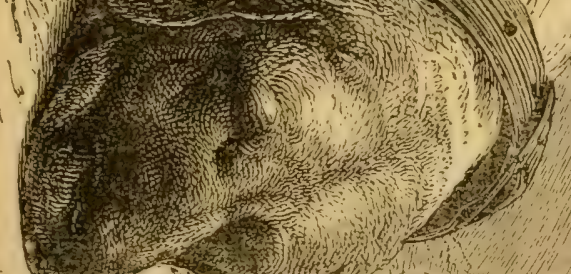

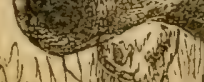

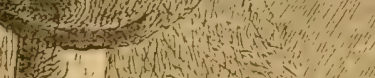




\section{NERO,}

\section{THE LARGEST DOG IN EUROPE.}

Yero, the subject of the foregoing engraving, was first exbibited at the Crystal Palace Dog Show in 1871, in the open or keepers' class, and was there, without a moment's hesitation, awarded the first prize. Ile was then about seven years old, and remarkable for his sym. metrical proportions, beautiful brown color, and enormous size; of the latter some idea may be formed by stating that at that time he weighed nearly 165 pounds. It is extremely difficult to assign a distinctive name to this breed. Some . incline to the belief that it is analogous to the southern hound; by some it is styled Welsh mastiff, and by others a cross with (with what not stated) the English bloodhound. The question of any suspicion of bloodhound is met by the dissimilarity of the ears which in the blood. hound are long, fine, and pendulous; whereas in this dog they are short and a little coarse, and, when excited, aro slightly "pricked ;" and whereas the bloodhound, as well as the mastiff, is well known to be averse to water, this breed would almost live in it. It is not improbable that it is a descendant of the hounds used in the chase centuries since, when wolves were common in England, the keenness of their scent being very tine.

'I'he dog is the property of Mr. Howel W. Williams, of Swansea, Wales. 



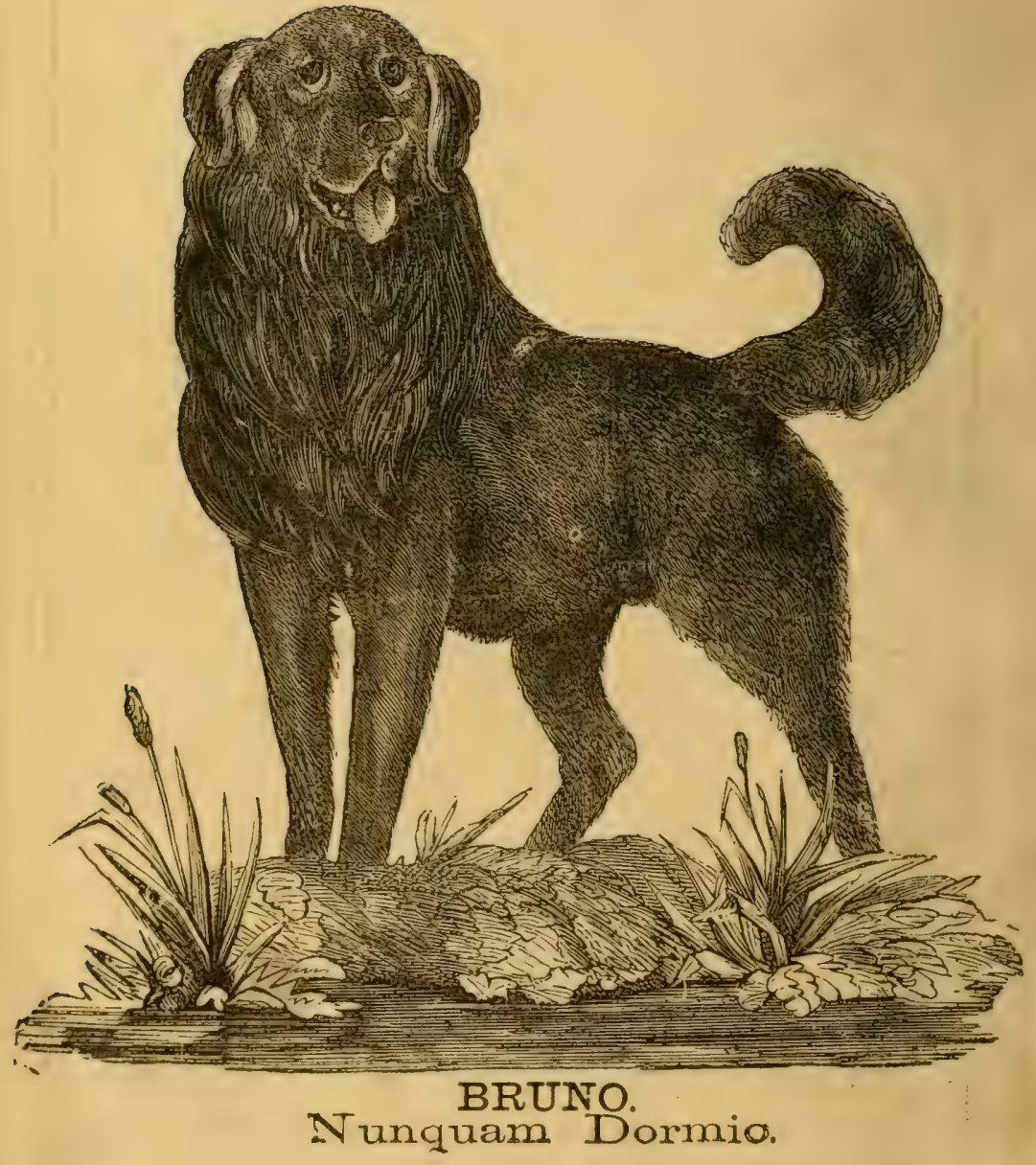




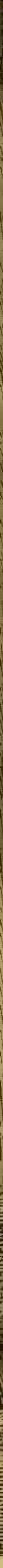



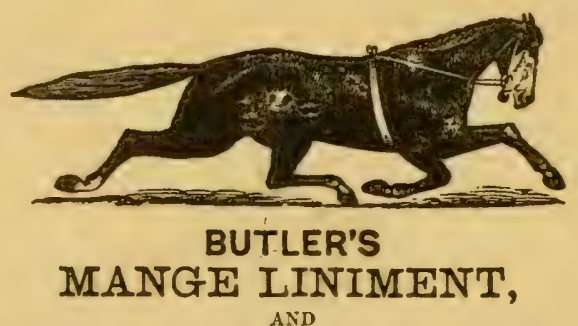

FLEA EXTERMINATOR

Is warranted a certain and speedy cure fol Mange, all sores, wounds, and diseases of the skin m horses and dogs; beautifying and restoring the hair. No dog will ever be troulued with fleas, where this is occasionally used. It immeibitely alliys all irritation of the skin, and its influence is almost magical in the reproduction of hair. No vermin c.n exist in its presence, and no dog, however delicate, can be injured by it. Warranted free from poison.

Prace 75 Cents per Bottle.

\section{BUTLER'S INFALLIBLE EXTERNAL REMEDY, AND \\ CAMP ANTIDOTE!}

Cures all external disorders or ailments-Wounds, Bruiscs, Sori's, Scalds, Burns, Venomous Bites, Eruptions, and Disens 's of the Skin; annibilates instantaneously, all kinds of Vurmin, is a perfect antidote and cure for Mosquito-Bites, an extracolinary preventive against Infection, is unequalled for the puritication of the camp, the hospital, or the dwell-

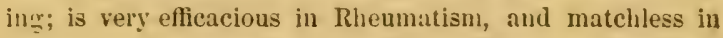
fromoting the growth of the Hair. Warranted free from jruison. Price One Dollar.

Sold by D. S. HOLMES,

Wholesale \& Retail, 89 Fourth St., Brookign, L. D. I: 








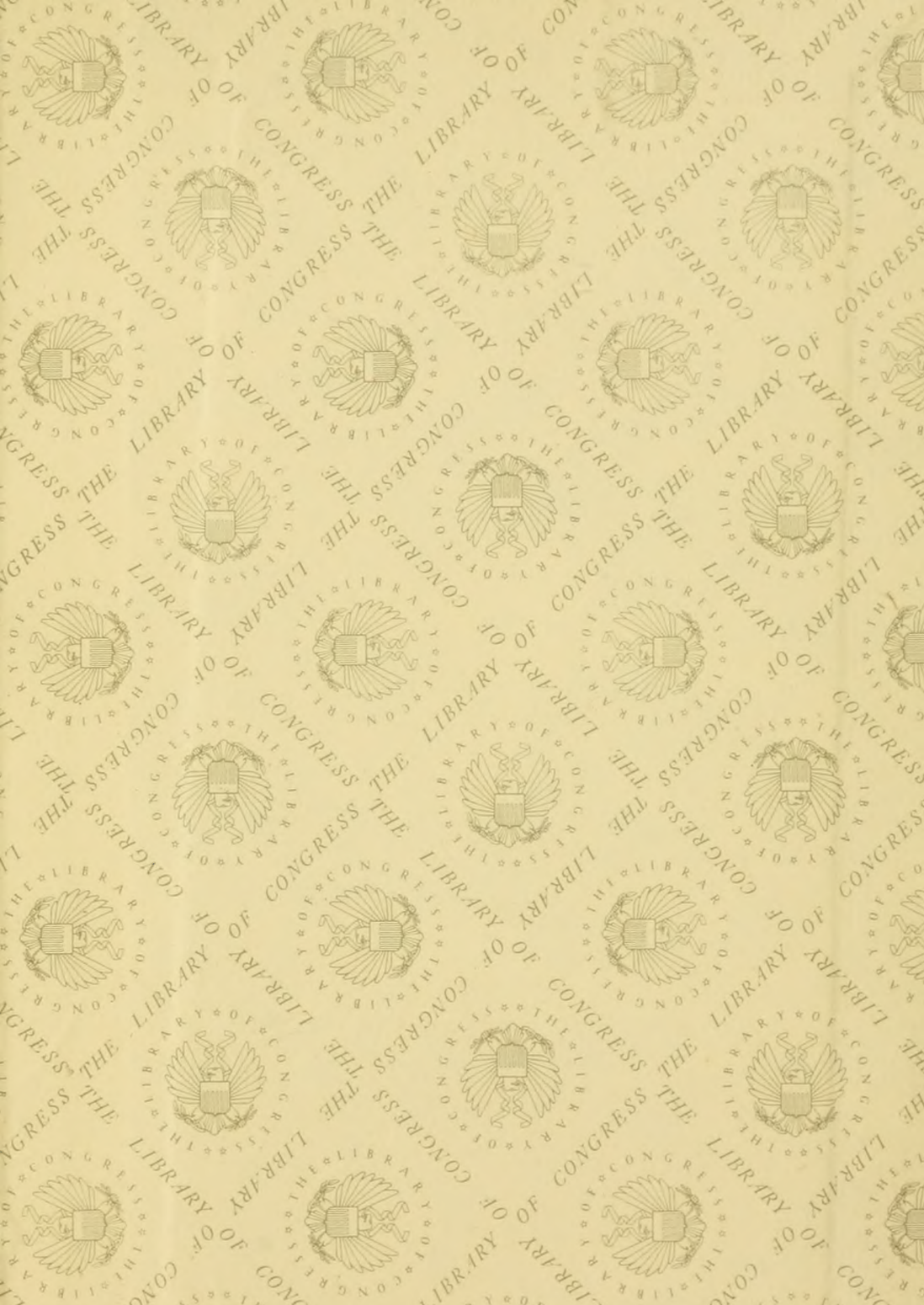


LIBRARY OF CONGRESS

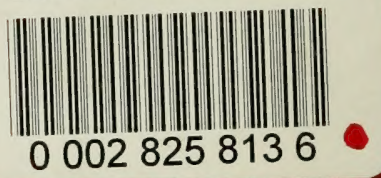

